Florida International University FIU Digital Commons

\title{
Landscape of fear : a social history of the missile during the early years of the cold war, 1950-1965
}

Jessica Rose Barrella

Florida International University

DOI: $10.25148 /$ etd.FI14050437

Follow this and additional works at: https://digitalcommons.fiu.edu/etd

\section{Recommended Citation}

Barrella, Jessica Rose, "Landscape of fear : a social history of the missile during the early years of the cold war, 1950-1965" (2007). FIU Electronic Theses and Dissertations. 1405.

https://digitalcommons.fiu.edu/etd/1405 
FLORIDA INTERNATIONAL UNIVERSITY

Miami, Florida

LANDSCAPE OF FEAR: A SOCIAL HISTORY OF THE MISSILE DURING THE EARLY YEARS OF THE COLD WAR, 1950-1965

A dissertation submitted in partial fulfillment of the requirements for the degree of DOCTOR OF PHILOSOPHY in HISTORY by

Jessica Rose Barrella 
To: Interim Dean Mark Szuchman

College of Arts and Sciences

This dissertation, written by Jessica Rose Barrella, and entitled Landscape of Fear: A Social History of the Missile during the Early Years of the Cold War, 1950-1965, having been approved in respect to style and intellectual content, is referred to you for judgment.

We have read this dissertation and recommend that it be approved.

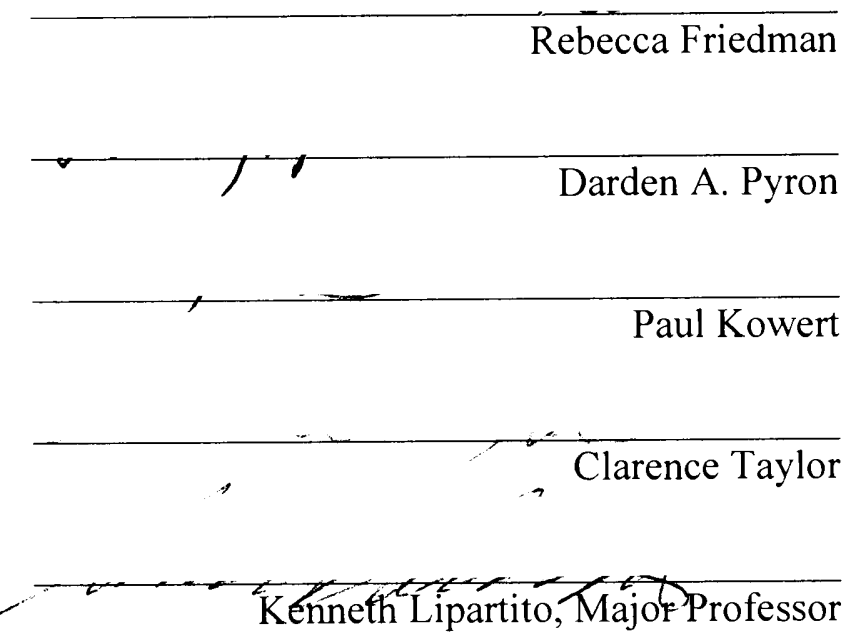

Date of Defense: March 27, 2007

The dissertation of Jessica Rose Barrella is approved.

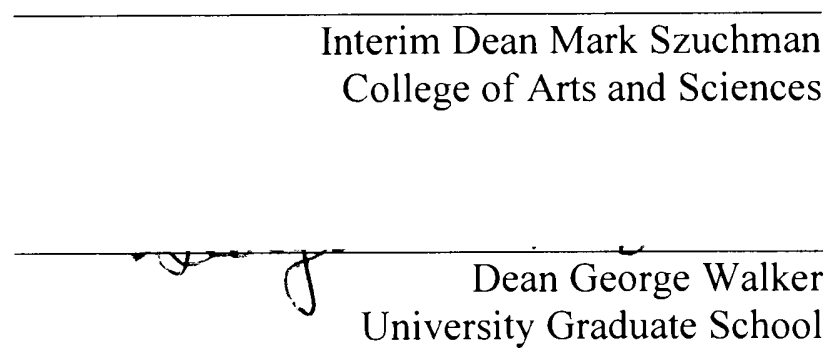

Florida International University, 2007 
(C) Copyright 2007 by Jessica Rose Barrella

All rights reserved. 


\section{ACKNOWLEDGMENTS}

This dissertation would not have been possible without the help of so many people I met along the way. I would like to thank the Nike Historical Society for their invitation to participate in their meeting, for all of their insight and the time that they took to answer my questions about operating the Nike during the Cold War. I would especially like to thank Ron Parshall and Gordon Lunn for their extra time, correspondence, and availability to answer questions along the way. Elaine Liston and Barbara Green archivists at the Kennedy Space Center, and Elbert E. "Sonny" Witt, Deputy Commander at Cape Canaveral Air Force Station gave me much of their time and patience.

The Better Business Bureau of Cheyenne, Wyoming was kind enough to send my email to various parties to provide me with contacts in the area. Captain Nicole Walters, $90^{\text {th }}$ Space Wing Public Affairs, F.E. Warren Air Force Base, provided me with a tour of the base and escorted access to F.E. Warren AFB Intercontinental Ballistic Missile and Heritage Museum, which otherwise would not have been possible to visit. Special thanks to Don and Charlene Zwoniter who invited a perfect stranger to their home, a converted Atlas E missile site. Brenda Blanke of the Sidney Telegraph was kind enough to help me photocopy articles from their archive when the microfilm machine at the public library stopped working. Michael Hosking, Cultural Resource Specialist at the Minuteman Missile National Historical Site gave me contacts and oral histories to further my research.

Much of my periodical research was done at Mount Union College and would not have been possible without the generosity of the library giving me a student pass. I would like to thank Florida International University History Department for their support and 
encouragement through this long journey, and for the FIU Dissertation Year Fellowship that made possible my complete dedication to the last year of writing and research. I would especially like to thank my committee members for their excitement in my project, their continued encouragement and detailed feedback. Finally, to my major professor, Dr. Kenneth Lipartito, thank you for directing the way, but letting me figure it out on my own. Your guidance is most appreciated.

I would also like to thank my family, friends, and a little puppy for their support. Without it, the journey would have been a lonely one indeed. 


\section{ABSTRACT OF THE DISSERTATION}

\section{LANDSCAPE OF FEAR:}

\section{A SOCIAL HISTORY OF THE MISSILE DURING THE EARLY YEARS}

OF THE COLD WAR, 1950-1965

by

Jessica Rose Barrella

Florida International University, 2007

Miami, Florida

\section{Professor Kenneth Lipartito, Major Professor}

The missile's significance has been central to national security since the Soviet launching of Sputnik, and became increasingly important throughout the years of the Cold War. Much has been written about missile technology, but little has been written about how the development and deployment of this weapon affected Americans. The missile was developed to both deter war but also to win war. Its presence, however, was not always reassuring.

Three areas of the United States are studied to evaluate the social implications of the missile during these pivotal years: San Francisco, home of multiple Nike installations; of Cape Canaveral, Florida, the nation's primary missile test center; the Great Plains, the location of the largest ICBM concentration in the country. Interviews were conducted, tours of facilities were taken, and local newspapers were reviewed. In conjunction with national newspapers and magazines and public opinion polls, this information provided a local social context for missile history. Nationally and locally, Americans both feared and praised the new technology. They were anxious for government funding in their cities 
and often felt that the danger the missile brought to their communities by making it as a Soviet target was justified in the larger cause for national security. 
CHAPTER

INTRODUCTION.

1 THE ULTIMATE WEAPON

2 A BUCK ROGERS WAR

3 ATOMIC PEARL HARBOR.

4 DEFENDER OF AMERICAN CITIES: THE NIKE MISSILE SYSTEM IN SAN FRANCISCO.

5 POWER FOR PEACE: THE TRANSFORMATION OF

CAPE CANAVERAL, FLORIDA

6 THE MISSILE NEST: HIDDEN MISSILES IN THE GREAT PLAINS 238

CONCLUSION. 273

BIBLIOGRAPHY 276

VITA .288 


\section{Introduction}

World War II ushered in a world of new uncertainties for Americans. The axis powers were defeated, but tensions between the allied nations were mounting. This was made evident with the partitioning of Europe after the war. Just as the United States and Great Britain were attempting to stabilize Europe by establishing democratic governments, the Soviet Union was likewise attempting to minimize future threats by establishing friendly governments around its periphery. Governments friendly to Communism were perceived as a direct threat to democracy and the antithesis of a "Free World." Soon the globe was being divided by these two opposing views, each perceiving the other as the enemy.

The Cold War was indeed two sided. The United States was relatively unscathed during the war and had become the richest nation in the world as a result of its industrial output. The Soviet Union, on the other hand, was devastated. Like Europe, Russia too needed aid to recover. But the Marshall Plan initiated in 1947 by the United States to help economically rebuild and stabilize war-ravaged Europe, was worded so that the Soviet Union would reject involvement and therefore not be eligible for monetary aid. In addition, the stabilization of Germany, while deemed necessary to the recovery of Europe, was seen as a direct threat to Soviet national security. What was seen as security for the Soviet Union was perceived as a threat to democracy, and thus a threat to the national security of the United States.

The Czech Coup and the Berlin Blockade of 1948 brought Cold War tensions to the fore. Both events provided evidence to the American public that the Soviet Union was 
indeed hostile. Only three short years after the close of the war it appeared that Americans would again fight. Communism was compared to Nazism, and Josef Stalin to Adolf Hitler. These tensions were exacerbated when the United States lost its atomic monopoly on August 29, 1949. The next year, China "fell" to Communism and the Korean War began. The dominos appeared to be falling faster and faster. It was against this international situation that Americans were becoming aware of missile technology and development. ${ }^{1}$

The missile became the key component of the defense arsenal of the United States. It was developed as the struggle between the Communist and non-Communist world climaxed. Indeed, the hottest chapter of the Cold War was the Cuban Missile Crisis. Yet, the turning point of American defenses has been attributed to the development of the atomic bomb. ${ }^{2}$ The bomb definitely forced Americans to view their world differently. President Truman considered the bomb to be his "winning weapon" against the Soviet Union before the end of World War II. ${ }^{3}$ Josef Stalin was well informed about the top-secret project and used information about its development to aid the Soviet

${ }^{1}$ Histories of the Cold War are plentiful, but key works include: Melvin P. Leffler, The Specter of Communism: The United States and the Origins of the Cold War, 1917-1953, New York: Hill and Wang, 1994; Walter LaFeber, America, Russia, and the Cold War, 1945-2000, $9^{\text {th }}$ ed., New York: McGraw Hill, 2002; John Lewis Gaddis, Strategies of Containment: A Critical Appraisal of Postwar American National Security Policy, New York: Oxford University Press, 1982; John Lewis Gaddis, We Now Know: Rethinking Cold War History, New York: Oxford University Press, 1997.

${ }^{2}$ See Richard Rhodes, The Making of the Atomic Bomb, New York: Simon \& Schuster, 1986.

${ }^{3}$ Gregg Herkin, The Winning Weapon: The Atomic Bomb in the Cold War, 1945-1950, New York: Alfred A. Knopf, 1980. 
Union in the creation of its atomic bomb. The American monopoly only lasted four years. ${ }^{4}$ Soviet atomic know-how helped to initiate the American hydrogen bomb project. $^{5}$ The United States needed to have the weapons to maintain atomic diplomacy. The Soviet and American hydrogen bomb project would remain neck-in-neck. It was time to rethink weapons development. Both countries turned their attention to creating a new, faster, and more precise delivery method. Intercontinental ballistic missiles were the result.

Much attention has been given to the social impact of the atomic bomb on American culture, but little consideration has been given to the bomb's new delivery method. The missile reduced delivery time and therefore reduced warning and preparation time. The missile was a new technology and with it came all the uncertainties that accompany the unknown. For years, Americans associated the missile with science fiction characteristics, and this association still exists today.

What has been written about missiles can be grouped into three categories: a specific missile history or general overview, technological, and administrative histories. Often these works are a combination and do not fit neatly into one specific category. There are few histories of specific missile systems. David K. Stumpf's Titan II: A History of a Cold War Missile Program is perhaps the most thorough study of an individual missile. Stumpf comprehensively examines the Titan II. By doing so he also explores missile development, administrative decision-making, and the complex technicalities of

\footnotetext{
${ }^{4}$ David Halloway, Stalin and the Bomb, New Haven: Yale University Press, 1994.

${ }^{5}$ See Richard Rhodes, Dark Sun: The Making of the Hydrogen Bomb, New York: Simon \& Schuster, 1995.
} 
the missile. ${ }^{6}$ Two books about the Nike are notable, not for their thoroughness, but for their contribution to the broadening of traditional missile history. Rings of Supersonic Steel by Mark L. Morgan and Mark A. Berhow focuses primarily on the Nike. Containing a brief history of Army Air Defense missiles, its main contribution is its detailed guide to missile locations throughout the country. For anyone looking for former Army missile sites, this guide is invaluable. ${ }^{7}$ Another notable missile history is the story of the Nike in Illinois by the National Park Service. Remarkable of the National Park Service and lacking in other works about missiles is their inclusion of social impact. But their contribution is limited. The Last Line of Defense: Nike Missile Sites in Illinois explains the technical history of the Nike, the role of the men who operated the missiles, and how the defensive missile impacted communities of the state. ${ }^{8}$ Another work by the National Park Service is "The Missile Plains: Frontline of America's Cold War," an internet-based resource published by the Minuteman Missile National Historic Site, South Dakota. ${ }^{9}$ The National Park Service also collects oral histories to record the social impact of particular missiles. But their collection is restricted to local histories of the sites that the Park

${ }^{6}$ Stumpf, David K. Titan II: A History of a Cold War Missile Program. Fayetteville: The University of Arkansas Press, 2000.

${ }^{7}$ Morgan, Mark L., and Mark A Berhow. Rings of Supersonic Steel: Air Defense of the United States Army 1950-1979, $2^{\text {nd }}$ ed. San Pedro, California: Fort McArthur Press, 2002.

${ }^{8}$ Carlson, Christina M. and Robert Lyon. Last Line of Defense: Nike Missile Sites in Illinois. Denver: National Park Service, Rocky Mountain System Support Office, 1996.

9 "The Missile Plains: Frontline of America's Cold War," Minuteman Missile National Historic Site, South Dakota, 2003. http://www.cr.nps.gov/history/online books/mimi/hrs.htm 
Service has designated as historical and does not extend to the broader national impact of missiles throughout the United States.

Works about missile development more often than not focus on a range of missiles from its inception to current day. Classic histories of the evolution of missiles, is Rockets, Missiles, and Men in Space by Willy Ley and ICBM: The Making of the Weapon that Changed the World, by G. Harry Stine. ${ }^{10}$ Ley's work, although dated, is worth reading because his history is from a scientific viewpoint, as he was a pioneer of space. Stine's work explores American missile development from an administrative perspective.

Perhaps the most comprehensive study of missile development is The Rocket: The History and Development of Rocket and Missile Technology by David Baker, which examines American missiles, Soviet missiles, and the role of missiles in space exploration." The newest book to be published about missiles is Clayton K.S. Chun's Thunder Over the Horizon: From V-2 Rockets to Ballistic Missiles, a brief history of missile development in the United States. Its focus is arousing reader interest in the role of the ballistic missile within current international relations. ${ }^{12}$ The most indispensable work about missiles which includes a concise technological, developmental, administrative, and (limited) social history of missiles in addition to site location, is the

${ }^{10}$ Ley, Willy. Rockets, Missiles, and Men in Space. 5th ed. New York: The Viking Press, 1968; Stine, G. Harry. ICBM: The Making of the Weapon that Changed the World. New York: Orion Books, 1991.

11 Baker, David. The Rocket: The History and Development of Rocket \& Missile Technology. New York: Crown Publishers, Inc., 1978.

${ }^{12}$ Chun, Clayton K.S. Thunder Over the Horizon: From V-2 Rockets to Ballistic Missiles. Westport, Connecticut: Praeger Security International, 2006. 
Army's contribution to the Cold War Project, To Defend and Deter: The Legacy of the

United States Cold War Missile Program, written by John C. Lonnquest and David F. Winkler. The first volume contains missile history; volume two lists exact missile locations, active status, and is organized by state. Its glossary contains a thorough list of all missiles, their contractors, and site designation. ${ }^{13}$ Like missile histories of the National Park Service, To Defend and Deter has a chapter about community impact and civil unrest. Although its social content is not extensive, it goes beyond local impact and mentions different incidents around the country.

Other works look at the missile as a technological artifact. Donald MacKenzie in Inventing Accuracy: A Historical Sociology of Nuclear Missile Guidance, argues that missile accuracy was a social process and not simply a technological one. The missile was and would have remained destructive enough without precise accuracy, but the importance of the weapon and its change of emphasis from a city buster to "counter force" dictated accuracy development. ${ }^{14}$

Works that commonly underscore the impact of the missile on everyday life are histories of the missile in space exploration. It was the missile that made the Space Age possible and it cannot be separated from its impact on Cold War society. Walter

${ }^{13}$ Lonnquest, John C. and David F. Winkler. To Defend and Deter: The Legacy of the United States Cold War Missile Program, vol. I. Department of Defense Legacy Resource Management Program, Cold War Project. Construction Engineering Research Lab (Army): Champaign, Illinois, 1996; Lonnquest, John C. and David F. Winkler. To Defend and Deter: The Legacy of the United States Cold War Missile Program, vol. II. Department of Defense Legacy Resource Management Program, Cold War Project. Construction Engineering Research Lab (Army): Champaign, Illinois, 1996.

${ }^{14}$ MacKenzie, Donald. Inventing Accuracy: A Historical Sociology of Nuclear Missile Guidance. Cambridge: MIT Press, 1990. 
McDougall highlights the unforeseen psychological impact of the Space Age by the launching of Sputnik I in The Heavens and the Earth: A Political History of the Space Age. ${ }^{15}$ The role of prestige and perception, he notes, were as important in fighting the Cold War as actual military force. The Apollo program is the story of Moonport: A History of Apollo Launch Facilities and Operations by Charles D. Benson and William Barnaby Faherty. ${ }^{16}$ The complex study of Apollo is not limited to its technological and administrative history; Moonport tells of the Space Race's impact to Florida's east coast.

Americans all over the country lived near missiles, helped build them, watched their development, participated in the celebration of the new weapon, and petitioned the government to house missiles in their communities. In some cases, they also voluntarily protected them or protested their arrival. Eventually the missile became simultaneously both an assurance and a threat to national security, but little has been written about the social impact of the missile during the early Cold War.

The missile was and is a collection of paradoxes. It was first developed for defense purposes, but as an offensive weapon, it negated defensive systems. There is still not an anti-missile missile. Missiles were also touted as a deterrent; thousands were built but they were called "the weapon least likely to be used." In addition, it was the missile that was employed to send man into space. "The ultimate weapon" was used and continues to be used for peaceful purposes. Perhaps most important was the fact that as

${ }^{15}$ McDougall, Walter A. ... The Heavens and the Earth: A Political History of the Space Age. New York: Basic Books, Inc., Publishers, 1985.

${ }^{16}$ Benson, Charles D. and William Barnaby Faherty. Moonport: A History of Apollo Launch Facilities and Operations. Washington D.C., NASA: 1978. 
missiles became more numerous and more powerful, they were hidden from view in the ground, and eventually they began to disappear from public awareness. Missiles were all around Americans: guarding cities, hovering in space, circling the earth, and planted around the country "like giant gopher holes.",

This dissertation's main focus is how the missile changed American's perceptions of their world. Missiles changed perceptions through public debate and discussionabout accidental war, Soviet first strike capabilities, and the possibilities for missile defense and deterrence. But missiles physically changed the land and communities as well. New technologies associated with missile development transformed American boundaries. Radar stretched to the Arctic and out into the oceans. Satellites circled the earth. Missiles range extended to halfway around the globe and eventually into outer space. These "push-button" weapons minimized the time civilians had to prepare for attack and forced revisions in civil defense procedures and urban planning.

The new landscape defined by missile technology became a landscape of fear. A technology intended to protect Americans, was also one that frightened them. Reliance on computers coupled with the possibility of human error had the public anxious that they could start was by mistake. In addition, new defenses, the public assumed, had to have its match in the Soviet Union. What was protecting Americans could very well be what would destroy them. These are intangible ideas, but very real concerns during the time. Cities that were thought to be primary targets built defensive missile fortifications both inside and outside city limits. Where people once thought they were safe, gigantic

17 "Ace in the Hole," Time, December 29, 1961, p. 12. While the Air Force was acclaiming the perfect Minuteman test, the Army was doing the same for the Nike Zeus, the new "anti-missile missile." 
intercontinental ballistic missiles transformed rural communities of the Great Plains to primary targets, and huge holes were dug to accommodate "missile cities" underground. But the missile also helped cities and economies grow both in size and importance.

This study is written in two parts. The first three chapters explore the psychological impact of missile development and how Americans perceived their world in light of this new technology of the Cold War. Chapter 1 focuses on how the press reported and disseminated information about the missile. Early missile development was cloaked in secrecy and information was limited at best. Often the press had to use educated guess work when reporting about the new weapons. Government secrecy in conjunction with heightened international tensions led the press to speculate about a missile race with the Soviet Union. Soon these fears transitioned into concerns of a missile gap. Very few Americans actually knew the truth-even Congress was excluded from highly classified clandestine operations. The lack of government transparency contributed to the press driven declarations of the missile race and the missile gap. These concerns also helped to shape elections, most notably John F. Kennedy's victory over Richard Nixon. Rightly or wrongly, the perceived missile gap reflected the public's lack of information about a rapidly evolving technology.

Chapter 2 examines how new technology contributed to fears of accidental war. So little was actually known about missiles and what many believed was based on science fiction. This contributed to the belief that from its earliest conception, missiles were launched with the touch of a button. This was actually not so. Early missiles were a complex system and involved many men to operate. It would take several years until missiles used actual "push-button" technology. But fears of accidental war abounded. It 
was the topic of several popular novels and was discussed in newly popularized think tanks. Public anxiety eventually made its way to Congress. Although military experts consistently assured Americans that accidental war was unlikely, both the Army and the Air Force created strict regulations to prevent its possibility. Public fears and dialogue of this issue illustrated how new technology became part of the debate about America's safety and position in the bipolar world of the Cold War.

This theme is continued in Chapter 3, which examines changing civil defense procedures. Efforts by civil defense authorities to keep pace with missile development, and thereby reassure the public, proved impossible. Scholars argue that Americans quickly became apathetic about civil defense and about the dangers of the Cold War generally. ${ }^{18}$ But I argue what has been taken as public apathy toward civil defense procedures actually reflected a sense of hopelessness toward protection from new weapons.

As Americans were learning more about atomic capabilities and reading scientific speculations about the power of the new hydrogen bomb, missiles were reducing warning times from three hours to fifteen minutes. Information about civil defense was not keeping pace with modern weapons. People were told how to prepare for a Hiroshima-

${ }^{18}$ Although not their main argument, important works on civil defense rely on public "apathy" to further their case. The most important of these works are: Guy Oakes, The Imaginary War: Civil Defense and American Cold War Culture, New York, Oxford University Press, 1994; Laura McEnaney, Civil Defense Begins at Home: Militarization Meets Everyday Life in the Fifties, Princeton, Princeton University Press, 2000; Andrew D. Grossman, Neither Dead nor Red: Civilian Defense and American Political Development during the Early Cold War, New York, Routledge: 2001; Kenneth D. Rose, One Nation Underground: The Fallout Shelter in American Culture, New York, New York University Press, 2001; David F. Krugler, This is only a Test: How Washington D.C., Prepared for Nuclear War, New York, Palgrave Macmillan, 2006. 
type bomb of only twenty-three kilotons when five-megaton bombs launched on missiles were already in the making. Safety and preparation could not keep pace with missile technology. This created a quandary: the government wanted limited information released as not to scare the public, but at the same time, felt the necessity to inform the public of military capability to garner support for increased national defense. What this eventually did, however, was heighten national despair.

The second part of the dissertation is about the actual physical changes to the landscape that happened as a result of missile deployment. Chapter 4 evaluates the Nike missile in San Francisco, California. Nike, first defensive missile system ever deployed, was intended to protect American cities thought to be Soviet targets. Living in a major city on the coast of California and only hours away from the nation's domestic atomic test site in Nevada, San Franciscans felt especially vulnerable to Soviet attack. The Nike was a complex system that worked in conjunction with new computers and distant radar networks circling the United States, expanding public perceptions of American borders. The Japanese attack on Pearl Harbor eradicated America's once protective Atlantic and Pacific Oceans. Missile technology once again redefined the borders of the United States. They created new perimeters in unseen radar lines radiating upward into the sky like an invisible shield and extending outward through the Atlantic and Pacific Oceans and Canada. Offensive missile technology quickly out paced the original Nike, making it obsolete almost as soon as it was deployed. Development on a new and improved missile began immediately. Despite improvements that led to the Nike Hercules, which contained a nuclear warhead, the Nike never achieved the promised protection. 
Chapter 5 extends the American landscape down the Atlantic Ocean and up into space. The designation of Cape Canaveral as the country's missile proving ground and later as home to the National Aeronautic and Space Administration's space program transformed the northeastern Florida coastline and extended the boundaries of the United States. The Cape was the first stepping-stone of the 5,000-mile Air Force Missile Test Center, which stretched to the Ascension Islands. Neighboring towns were also directly affected by missile development. Residents were self-proclaimed "bird watchers" and embraced the missile as a symbol of technological prowess, economic accelerator, and patriotism. Residents also felt personally vested in missile development because of their interaction with and embracing of relocated servicemen and contractors. As the Cold War extended to space, the area became synonymous with the space race. The Space Age had transitioned the missile from a weapon of war to a weapon of peace.

The final chapter explores the underground. As intercontinental ballistic missiles developed and became more sophisticated, they were buried more densely and deeper into the earth. By 1965 , solid fueled ICBMs became smaller, cheaper, and simpler to operate, using less manpower. Strategic defense policy shifted from defensive missiles placed around target cities, to a thousand offensive missiles planted throughout the country. It was presumed that enough would survive a Soviet attack to be able to strike back. The core of what became Cold War policy, deterrence through massive retaliation, required a new landscape of missile deployment.

This transition was especially noticeable in the Great Plains, where the majority of America's missiles were housed. During the earliest years of the Cold War, the Plains were considered the safest place in the country: far from the coast and highly populated 
target cities that missiles like the Nike were meant to protect. Civil Defense literature focused on protecting urban residents from blast and fall out by evacuating residents to the countryside as a defense measure. City planners designed urban centers that dispersed the population from the nucleus to satellite districts. The ICBM, however, pushed this remote area to the forefront of defense by making its small towns new primary Soviet targets. Again Americans were forced to reevaluate their landscape. The missile had transformed from city buster to counter offensive weapon, shifting the focus of war from coastal cities to the heart of the country. No one was safe. City evacuation was impossible and there was only thirty minutes to find shelter. No one was able to "run to the hills" because missiles proliferated the country.

Ironically, most Americans embraced the IBCM and welcomed it into their communities. Despite fears expressed in popular literature, the missile had by $1960 \mathrm{~s}$ developed a more positive reputation. The connection to space, the publicity of missiles at Cape Canaveral, and the emphasis on deterrence-or the non-use of missiles-calmed fears of accidental war, push button war and other fears that had fed the deep sense of dread in the 1950s. Many small towns in the interior states petitioned for an ICBM site. Eastern Wyoming was of strategic importance and its influence radiated to nearby states. Nebraska believed that it could gain federal recognition and receive government aid only by being strategically important to national defense: it petitioned for missiles. Like other technologies, the missile enhanced local economies and became a sign of local and national pride.

The new technology did not convince everyone, however. Ranchers of South Dakota and the workers constructing the sites were among the loudest dissenters. But 
their concern was centered on compensation more than nuclear concerns. These men did not view their actions as unpatriotic and were eager for others to understand their complaints. By this time the missile had manifested into a sign of patriotism and any dissent was labeled as disloyal. Many American felt that the missile was a burden that needed to be accepted.

Like works before this, I use government documents to provide a national context for missile discourse, such as the Congressional Record and Foreign Relations of the United States. But to write a social history of the missile, I relied more heavily on the news sources, popular magazines, novels, and public opinion polls. Until the later half of the 1960s, news magazines and newspapers were the primary source of information for most Americans. American news magazines were prevalent in homes across the country. In the early years of the Cold War, local newspapers and national news magazines were the primary source of news for Americans. ${ }^{19}$ Several magazines, however, were published and edited by the same publisher, attesting to their power to influence public opinion. $^{20}$ Secrecy abounded during the early years of the Cold War, but in its place speculation flourished to inform Americans about Soviet intentions and capabilities.

${ }^{19}$ Television had not yet a staple fixture in most homes. Time, Newsweek, U.S. News and World Report, Reader's Digest, and Life had several million subscribers by the late 1960s.James Playsted Wood, Magazines in the United States, $3^{\text {rd }}$ ed. (New York, 1971).

${ }^{20}$ An example: Life, Fortune, and Time were published by Henry Luce, a staunch antiCommunist. His publishing format was to "select the facts, tell what the facts meant, and state or strongly suggest what the reader should think or feel about them." Ibid. p. 209. 
News, however, was selective: the reporter decided what was news worthy. ${ }^{21}$ Often during these tense years, war and technology were newsmakers, and both proliferated headlines. The repetition of war alerts, civil defense needs, and new weapons attests to the power of the press. But most importantly for purposes here, is the regularity of what the public was reading and viewing. Some reports were true, some were fabricated, and many were exaggerated, but Americans believed what they were told from sources they trusted. To accurately and acutely understand what Americans were seeing and reading regularly, I closely examined popular magazines and novels from 1950 to 1965 . To gauge public reaction to current events, I relied on polls. Public polls were collected locally through newspapers and nationally by the Gallop Poll and Public Opinion Quarterly.

But information about missiles was not limited to the printed word; missiles increasingly became a popular image in advertisements. As the missile shifted to the center of the defense arsenal, it became a symbol of patriotism. The weapon's increasing importance was evident is advertisements. Themes that were consistently printed matched with information gathered in the Gallop Polls and aided in the formation of the chapters in the first half this dissertation. In addition, for Chapter 3, the use of Civil Defense manuals and documents printed by the Federal Civil Defense Agency gave a better understanding of the information that was distributed to communities around the United States.

${ }^{21}$ William L. Rivers, The Opinionmakers, (Westport, Connecticut, 1965); David L. Paletz and Robert M. Entman, Media, Power, Politics, (New York, 1981); Tom Wicker, On Press, $3^{\text {rd }}$. ed, (New York, 1978). 
The second part of this study relies more on the local sources of each of the three case studies. In addition to national news magazines and advertisements, I used regional new papers and interviewed men who worked closely with missiles. The National Park Service maintains areas around the country that are preserved missile sites. Many sites have fallen into disrepair and are only visible with the help of a guide. This was especially evident of the Nike missile sites circling San Francisco. Visiting these instillations and talking with men who maintained and operated the missiles was invaluable to researching the missile's social impact on American life during the early years of the Cold War.

It is my intent that this dissertation will aid in the understanding that the missile was as important to changing American perceptions of their world as the atomic bomb. The missile ushered in a new age: an age of no defense. Just as the country relied on the intercontinental ballistic missile to deter the enemy, it relied on the same weapon to win war. 


\section{Chapter 1}

\section{The Ultimate Weapon}

The ICBM is the nearest thing to the "ultimate weapon," complete with delivery system, that has ever been conceived. From U.S.-controlled territory, it could reach any part of the world, wreck the biggest city by blast and heat. Then the radioactive byproducts drifting with the wind, could turn an area the size of many nations into a silent wilderness. An enemy's version of the ICBM could do the same to any part of the U.S. ${ }^{1}$

Missiles and the new technology that accompanied them were often both a promise of protection and an enemy threat. Popular news magazines frequently had to speculate about missile development because of the secrecy that surrounded them. Their articles became increasingly alarmist as the Cold War intensified. Reporter speculation and tone of urgency fueled the arguments of a "missile race" and a "missile gap." Fear of the new weapon heightened domestic anxieties and Cold War tensions as the missile race and missile gap appeared to intensify.

Before World War II the rocket was a symbol of the future and was often associated with science fiction fantasy, but the German use of the V-2 - the "world's first long-range ballistic missile"-during the war changed that image. ${ }^{2}$ The rocket had become a means to wage war. As a new weapon, it had a lasting psychological impact,

\footnotetext{
1 "Missiles Away," Time, January 30, 1956, p. 56.

2 John C. Lonnquest and David F. Winkler. To Defend and Deter: The Legacy of the United States Cold War Missile Program, vol. I (Champaign, Illinois, 1996), p. 15.
} 
but its "ability to evoke contemporary fears [was] heightened by the use of new and mysterious technology" rather than fear of its destructive power. ${ }^{3}$

The image of the rocket as a futuristic means of space travel was brought to public attention by the writing of Jules Verne in the second half of the nineteenthcentury. ${ }^{4}$ His works propelled the rocket to interest among the scientific community. Most notable was the work of Konstantin Tsiolkovsky of Russia. He began experimenting with the concepts of space flight and rockets over two decades before the turn of the century and paved the way for other space enthusiasts. By the beginning of the twentieth century, Robert Goddard of the United States, and Hermann Oberth and later Wernher von Braun of Germany were making their mark in rocketry and gaining national and international attention. ${ }^{5}$ In the Soviet Union and Germany, rocket science was taken much more seriously than in the United States-Robert Goddard was better known in these two countries than he was in his own. ${ }^{6}$ The Soviet Union under Lenin funded rocket

${ }^{3}$ Edgar Jones, Robin Woolven, Bill Durodié, and Simon Wessely, "Public Panic and Moral: Second World War Civilian Responses Re-examined in the Light of Current AntiTerrorist Campaign," Available at: http://64.233.167.104/search?q=cache:wOiq_Z6UxgJ:www.terrorismresearch.net/finalre ports/Jones/PublicPanicandMorale.pdf $+\mathrm{v} 2+$ rocket + psychological + implications\&hl=en\& $\mathrm{gl}=\mathrm{us} \& \mathrm{ct}=\mathrm{clnk} \& \mathrm{~cd}=9$

${ }^{4}$ Peter Costello, Jules Verne: Inventor of Science Fiction (New York: 1978).

${ }^{5}$ It is worth mentioning that the British had their own rocket scientist: Colonial William Congreve. He made notable contributions to rocketry in the eighteenth century.

${ }^{6}$ In 1919 Goddard wrote a monograph for the Smithsonian in which he proposed rocket propulsion as a means of reaching high altitudes. This monograph was mocked by a New York Times editorial as being unscientific and suggested that the Smithsonian was "being defrauded." Paul A. Carter, The Creation of Tomorrow: Fifty Years of Magazine Science Fiction (New York, 1977), pp. 31-32. Most of Goddard's subsequent work was kept secret for fear of press exploitation. 
research, putting it years ahead of Germany and the United States. The Bolsheviks heralded science and technology, and shortly after the Bolshevik Revolution, Tsiolkovsky was proclaimed a national hero. In fact, not until the Stalinist purges of the late 1930s did developments in Soviet rocket science fall behind its peers. But after World War II, with the help of emigrated German scientists and with strong support from Joseph Stalin, the Soviet Union quickly accelerated its rocket program and was again the world leader. White House officials and the American public generally overlooked the important role of science in the Soviet Union. As a consequence, Soviet technological accomplishments took Americans by surprise and led many to question and doubt their authenticity. ${ }^{7}$

Rocketry in the United States received little military attention in the 1930s and early 1940 s. $^{8}$ Each branch of the military had it own missile project but development was limited because of budgetary restraints, a lack of vision, and an interest in expanding traditional-and reliable--weapons. ${ }^{9}$ Nevertheless, rivalries arose between the Air Force,

${ }^{7}$ Although American officials believed otherwise, Stalin looked at long-range bombers to deliver atomic weapons and "missile received equal priority." David Holloway, Stalin and the Bomb: the Soviet Union and Atomic Energy, 1939-1956 (New Haven, 1994), 145-147; 245-250. According to Khrushchev, Stalin also made the decision to develop surface-to-air missiles, and claimed to have had them circling Russian cities until his death. Nikita Khrushchev, Khrushchev Remembers: The Last Testament (Boston, 1974), pp. $43-44$.

${ }^{8}$ Goddard's work was largely dismissed in scientific circles, particularly because rockets were still associated with science fiction and space flight. A. Scott Berg, Lindbergh (New York, 1998), p. 211.

${ }^{9}$ Tom D. Crouch, Aiming for the Stars: The Dreamers and the Doers of the Space Age. (Washington D.C., 1999. In 1936 a group of graduate students at the Guggenheim Aeronautical Laboratory at the University of California (GALCIT) lead by Frank Malina were experimenting with rockets, and the Army Air Corps soon recognized their work. By 1944 they began referring to themselves as the Jet Propulsion Laboratory (JPL). They 
Navy, and Army over control of rocket technology. The shrinking defense budget of the early post-war years, however, drastically cut military spending and missile development in the United States came almost to a stand still. ${ }^{10}$ The Army and Air Force continued limited development, as did private contractors, but cost restraints placed its priority on the back burner until funding could become available. ${ }^{11}$ The limited scope of rockets in the United States changed in 1949 when the Soviet Union detonated an atomic bomb and shattered American sense of security. The Russians, it now appeared, were more scientifically apt than previously thought—or had been given credit. This resulted in renewed emphasis on missile development in the United States.

made two major contributions to the post-war missile effort: the Army's Corporal, the "first tactical-range surface-to-surface missile" was developed before war's end; Caltech laboratories became "the training ground" for scientists and engineers who played a major role in missile development in the United States. Lonnquest, To Defend and Deter, vol. 1, pp. 15-17.

10 The Air Force at the end of the war had a "self-proclaimed monopoly on delivering atomic weapons," and because the armed services traditionally determined their roles within their operational environment, the role of the missile was hotly contested. The rivalry resulted in the McNarney Directive. It stated that the Army Air Force (AAF) would be responsible for "missiles launched from aircraft as well as surface-to-surface missiles equipped with wings that provided aerodynamic lift." The Army Service Forces would be responsible for "surface launched missiles that depended exclusively on momentum for sustaining flight." To reinforce its claim that missiles where within the strict domain of the Air Force, the AAF "reclassified its air-breathing missiles as "strategic pilotless bombers." The missile debate between the Army and Air Force would lead to tense relations - which eventually would present itself to the public. Lonnquest, To Defend and Deter, vol. 1, pp. 20-24.

11 The AAF continued work on two air-breathing missiles over the ICBM with the Snark and Navaho- both which looked like aircraft. Consolidated Vultee Aircraft Corporation (Convair) who was working with the AAF continued to support missile development with its own limited funds and without government sponsorship. The MX-774 was the only ICBM project when AAF canceled it in 1947. David Baker, The Rocket: The History and Development of Rocket \& Missile Technology (New York, 1978), p. 98. 
In 1950, news magazines began emphasizing the future importance of missiles in the Cold War. Interest was spurred by the designation of Cape Canaveral, Florida, as the new long-range missile proving ground and by the recently erupted Korean War. U.S. News and World Report predicted that missiles would be developed to "ultimately" replace conventional weapons and prophesied a missile race. The periodical predicted, "[t]he nation that slips up now in basic [missile] research may not get a chance to catch up."12 It was clear that technology was quickly changing and news magazines spiked the curiosity of readers by turning missiles, once regarded as minor weapons or the stuff of science fiction fantasy, into something tangible and important to the security of Americans.

Changing technologies made Americans feel both vulnerable to and protected from attack during the early years of the Cold War. The reports of the increased flight altitude of post-war bombers were a threat to coastal cities, and new surface-to-air missiles were thought to be the answer. Newsweek told its readers that studies by the Joint Chiefs of Staff (JCS) "indicated that in a few years the Nike [the first defensive surfaceto-air guided missile in the world]" would "sufficiently alter the power of enemy bombers to damage U.S. targets."13 With new technology, the United States could counter Soviet strength in numbers. By January 1954, U.S. News and World Report promised that surface-to-air missiles could stop the nuclear threat: "In the place of

12 "Faster Rockets: Big Gain Shown in Guided Missiles," U.S. News and World Report, April 21, 1950, p. 16; "Guided-Missile Preview: A New Arsenal for U.S.," U.S. News and World Report, March 31, 1950, p. 20.

13 “Step Forward in Air Defense," Newsweek, October 20, 1952, p. 38. 
hopelessness, weapon development at this time offers hope with a promise of success in event of attack." ${ }^{14}$ In autumn of that year, the Army began deploying the Nike-Ajax. ${ }^{15}$ The Nike was developed to replace the already outdated antiaircraft guns used during the Second World War. The Nike system was intricate and operated in conjunction with an impressive network of radar and computers known as SAGE (Semi-Automatic Ground Environment). Using the pioneering Whirlwind digital computer, the SAGE network could process information faster than humanly possible. ${ }^{16}$ It seemed a reassuring defense mechanism: a push-button technology that would keep America safe in the rapidly accelerating Nuclear Age.

Many questioned push-button technology, and the concept of "push-button war" became popular in the later half of the decade. It provided both a frightening image of the dangers Americans faced as well as hope against those dangers. In fact, much of the technology was not instantaneous. SAGE was intricate, its calculations were not immediate, and it required more human participation than the popular press let on. Because little information was given to the public, many worried about accidental firings and missiles falling out of the sky on civilians. In addition, Americans assigned familiar

14 "Atom Bomb Can be Stopped: Secret Weapons Cut Threat to Cities," U.S. News and World Report, January 8, 1954, pp. 19-23.

${ }^{15}$ The press did not differentiate the Nike Ajax from its successors. This may have been because almost as soon as the Nike Ajax was deployed, the Army began to make significant advances, which eventually changed the weapon itself. The four Nike systems are: Ajax, Hercules (both AA), Zeus (the first anti-missile missile-but never deployed) and Nike X (also an anti-ballistic missile). James R. Chiles, "Ring of Fire," Air \& Space Smithsonian (July 2005): 33-39. For more information about the Nike, see Chapter 4.

16 "Mathematical Defense: 'SAGE' Against an Attacking Enemy," Newsweek, January 30, 1956, pp. 88-89; Thomas P. Hughes, Rescuing Prometheus: Four Monumental Projects that Changed the Modern World (New York, 1998), Chapter 2. 
fictional characteristics to this technology they did not understand. This was exemplified in an article by Rear Admiral D.V. Gallery of the U.S. Navy for The Saturday Evening Post. Written to quell anxieties of guided missiles, the Admiral addressed what he felt were false public fears. People should not act irrationally about what they do not understand, he argued, because "[s]uch hysteria over the new and mysterious is dangerous." The Admiral continued, "It can panic us into going off half-cocked, and foolishly scrapping things still vital to the national defense of wild rumors about Buck Rogers (sic) type weapons." Fear of new weapons was nothing new and fears were often aroused by major weapon developments. ${ }^{17}$ General Carl Spaatz of the U.S. Air Force, however, contradicted the Admiral and upheld public fears when he announced, "the planes shot down [with Nikes] on the perimeter of thickly populated areas will do about as much damage falling to the ground where hit as they would do if permitted to reach their targets. ${ }^{\prime 18}$ Americans were left wondering what to believe.

The Nike and its related missile defense systems, however, were not the main thrust of development in the 1950s. Military leaders tried to convince officials and the public that offensive ballistic-type missiles were the key to American security. ${ }^{19}$

\footnotetext{
${ }^{17}$ Rear Admiral D.V. Gallery, USN, "Don't Get Hysterical About Guided Missiles," The Saturday Evening Post, June 13, 1953, p. 31.

${ }^{18}$ General Carl Spaatz, "Missiles? Fine. But Humans Won't be Supplanted," Newsweek, May 2, 1955, p. 28. The danger of falling missiles onto cities they were supposed to be protecting was a reoccurring theme, but the reason Spaatz published his comments may have been political. The Nike was an Army missile. However, there were other public objections to Nike sites, especially concerning sacrificing city land. Chiles, "Ring of Fire," p. 35.

${ }^{19}$ Rear Admiral D.V. Gallery, USN, "Don't Get Hysterical About Guided Missiles," The Saturday Evening Post, June 13, 1953, p. 31.
} 
Offensive ballistic missiles were still in the developmental stages but were already predicted to be unstoppable. ${ }^{20}$ This created both assurances and fears: the missile would be the ultimate weapon for defense purposes, but they also appeared undefeatable if used to attack the United States. Despite the fear these future weapons created, Americans were told that they could rely on the effectiveness of Nike missile defense.

The Nike, in fact, was the last line of defense against atomic attack. Defense against Soviet aggression actually started far from city borders with a radar network reaching out to the hinterlands of Canada. ${ }^{21}$ Time featured an extensive report to introduce Americans to this elaborate defense system. There was a "Supersonic Shield" that protected Americans from the enemy, readers were told. The article opened with a dramatic scenario of possible Soviet attack:

If Moscow should decide some midnight to attack the U.S., 900 Soviet heavy bombers could be over North America by dawn. Some 300 planes, manned by elite crews and loaded with nuclear or thermonuclear bombs, would streak toward vital U.S. target areas. The others, carrying TNT and fire bombs, would serve to divert and confuse U.S. defenses. Twoscore (sic) well-placed hydrogen bombs would kill one-fourth of the American people; conceivably, an all-out surprise attack could destroy the nation's will to resist and power to strike back.

20 The fear of future ballistic missile attack was a reoccurring one. One frequent commenter was the first Secretary of the Air Force and in the early 1950s, the "most informed man on air power," Senator Stuart Symington (D-MI). He argued that each day that goes by sees the military strength of the U.S. and its allies become weaker in comparison to the Communist. He foresaw the coupling of the atomic warhead and the ballistic missile and believed that it was highly possible that the enemy would develop them first. "The Drying Wood," Time, August 2, 1954, pp. 11-12.

21 “Atom Bomb Can Be Stopped." 
. . . By military standards, the danger of a Red strike against the

U.S. is greater now than ever before. The Soviet Union is very nearly capable of a knock-out blow delivered without warning. ${ }^{22}$

After frightening readers, Time informed them of the great strides in Air Force defense. A joint venture by the United States and Canada was providing maximum security through a "fence in the sky," or a Distant Early Warning (DEW) radar line. Ringing through Canada up to the Arctic, this radar would allow for at least three hours notice in case of such an attack. In conjunction with the North Atlantic Treaty Organization (NATO), the DEW lines were intended to be fully operational by the end of 1958 , extending from Argentina to the Azores and from Greenland to the Faroe Islands, eventually tying into the British radar system. ${ }^{23}$ These technological advances in air defenses appeared to extend American borders and bread overconfidence in American superiority, which was soon reflected in the rhetoric of defense officials and some scientists.

By spring 1955, the attitude of Pentagon officials changed when they spoke of American security. Previously it was admitted that the Soviets were ahead in missile technology. Now Americans were told that the United States would be the first to develop an intercontinental ballistic missile. Officials appeared "confident, if not cocky,"

22 "The Supersonic Shield," Time, December 20, 1954, pp. 15-19. The first public glimpses of missile deterrence were seen in this article: "[D]anger is no cause for despair. Top U.S. Strategists believe that the Soviet Union may never make a successful attackor any kind of attack - so long as the U.S. keeps up its guard and, above all, its ability to strike back. A strong, alert defense, by its very existence, can help to preserve both the peace and the U.S." p. 17.

${ }^{23}$ Memorandum for Discussion at the 292nd Meeting of the National Security Council, Washington, August 9, 1956, Foreign Relations of the United States, 1955-1957, vol. 19: National Security Policy: 338-345 (Hereafter, FRUS). 
about this ability Newsweek informed readers. ${ }^{24}$ By 1955, the Eisenhower administration had turned its focus toward missile development. As a result of the Technological Capabilities Panel Report (better known as the Killian Report), Eisenhower initiated a ballistic missile program of the "highest priority above all others," and new missiles quickly entered the American arsenal. The Department of Defense decided to develop both the intermediate range ballistic missile (IRBM, with a range of up to 1500 miles) and the intercontinental ballistic missile (ICBM, with a range greater than 6000 miles) simultaneously. At the time it was believed that the development of the former would naturally lead to the development of the later-which did not happen. ${ }^{25}$ The race was on to successfully test a missile before the Russians.

While the public was being inundated with war scenarios and maps of possible Soviet attack by the press, they were also being told of the destructive capabilities of new missiles. The first of the new long distance weapons the public learned about was the Atlas intercontinental ballistic missile. It would be able to fly half way around the globe to deliver an atomic blow to the Soviets. As Air Force Secretary Harold E. Talbott remarked to the press: "Remember this: the speed of the Germans' V-2 missile as it plunged down at its target was over 3,500 miles an hour. Can you imagine intercepting it? Two of us might as well stand at opposite ends of a hall and pitch needles at each

\footnotetext{
24 "Push-Button Defense?" Newsweek, May 2, 1955, pp. 27-30.

${ }^{25}$ Report Prepared in the Department of Defense, "Report on the Department of Defense Intercontinental Ballistic Missile and Intermediate Range Ballistic Missile Programs," Washington, Undated, FRUS, 1955-1957, 19:161-166.
} 
other in the hope that the needles might collide. ${ }^{26}$ Press releases concerning the Atlas were meant to calm public fears about American vulnerability. The ICBM, it was believed, would be invincible.

Embodied within the language of American missile development was the need for the United States to win the "missile race." First implied in 1950, the race made itself evident, as new missile technology became public knowledge. The urgency to successfully develop a deliverable missile before the Soviet Union became a headline staple of news magazines, and throughout the first part of the decade it was clear the race was gaining momentum. Whether there was a missile race before the press declared there was is doubtful. It was the constant rate with which the statement appeared and the tone of importance used by the press that led Americans to believe there indeed was a missile race.

Public outcry in reaction to these headlines eventually accelerated the missile project. Newsweek declared in 1955 that the first nation to build a successful ICBM "will have won the cold war." ${ }^{27}$ By the beginning of 1956, U.S. News and World Report informed readers that "the race between the United States and Russia to be the first with an 'ultimate' weapon is headed down the home stretch." 28 This "race" became of primary importance to national security because it was predicted that a U.S. achievement of the

26 "Enter the IBM," Time, December 6, 1954, p. 28. IBM was the first acronym for the Intercontinental ballistic missile, but because of confusion with the computer company, it was changed to ICBM.

${ }^{27}$ Ibid.

28 "Across the Atlantic in 30 Minutes," U.S. News and World Report, January 20, 1956, pp. 21-24. 
ICBM would protect the free world, but a Soviet success would directly lead to another world war. ${ }^{29}$ In addition, an American success would assure its allies that it was technologically superior to the Soviet Union, which the United States hoped would stiffen European resolve against Communist expansion. As the rhetoric of the "missile race" appeared in magazines, the official view of Soviet missile technology shifted from ahead of the United States to behind. ${ }^{30}$

The information given to Americans about the nation's missile program was often contradictory and heightened uncertainties of the future. In the January 20, 1956 issue of U.S. News and World Report, there were several articles with in-depth coverage of the U.S. missile program. "Across the Atlantic in 30 Minutes" highlighted the Russian threat and charted the implications behind the need for the United States to develop the missile first. A subsequent article, "If Russia Wins the Missile Race—," added a more objective view of the progress that had been made and predicted that it would not be a big deal if the United States "lost" such a race.

Information given by President Eisenhower was equally confusing. When asked by members of the press whether the United States was falling behind in the missile race, Eisenhower was vague and did not answer the question. He replied that much money was

${ }^{29}$ While the missile debate was brewing in the press and among Congressional members, the White House did not feel the same pressure. This was a result of U-2 flights over the Soviet Union, which confirmed Eisenhower's belief of the inadequacies of the Russian missile progress.

${ }^{30}$ This is an interesting view, considering that the United States had "an enormous amount" of intelligence regarding Soviet missile development from 1950-1957. G. Harry Stine, ICBM: The Making of the Weapon that Changed the World (New York, 1991), p. 162. 
being put into missile development, but missiles were not as accurate as "shooting a gun or dropping a bomb from a plane," and their use would lead to "[human] race suicide." 31 Despite this grim outlook, nuclear deterrence through missile development continued to be central to Eisenhower's national security doctrine. The New Look sought a flexible response to the Soviet military threat. In conjunction with a variety of continental defense systems, there was a build up of nuclear weapons to support a doctrine of "massive retaliation" (the idea that the United States could absorb a "first blow" and be able to effectively retaliate unexpectedly). As historian Richard Damms explained, this policy would allow the United States to "increase its reliance on high-technology, capitalintensive strategic delivery systems while reducing more costly conventional forces. ${ }^{~} 32$ Since Eisenhower did not differentiate nuclear weapons from conventional weapons, their eventual use in future war was not questioned and offensive missile development and dispersal evolved easily into this policy. ${ }^{33}$

The implications of ICBM development were the feature of Time's January 30, 1956 issue. With a cover drawing of an x-rayed missile flying in the night sky toward an illuminated city, the headline simply stated "The Missile." More ominous drawings were

31 "Across the Atlantic in 30 Minutes," U.S. News and World Report, January 20, 1956, pp. 21-24; "If Russia Wins Missile Race-" U.S. News and World Report, January 20, 1956, pp. 25-26; Dwight D. Eisenhower, "President's News Conference of February 8, 1956," Public Papers of the Presidents of the United States, Dwight D. Eisenhower, 1956. (Washington D.C.: GPO, 1958), pp. 234-5 (Hereafter, Public Papers).

32 Richard V. Damms, "James Killian, the Technological Capabilities Panel, and the Emergence of President Eisenhower's 'Scientific-Technological Elite," Diplomatic History 24 (Winter 2000): 57-78.

${ }^{33}$ More about the New Look policy is written in Chapter 2. 
featured inside with careful explanations of its destructive potential. The article explained that missiles were nothing new, but emphasized the technological revolution that had taken place to develop them. Computers and automation, it appeared, were going to replace man. "In the past ten years the world of electronics has evolved beyond recognition. Computers, the brains of missiles, have grown in intelligence as fast as the magic unfolding of a child's mind." Accuracy, it was argued, was secondary in importance to destructive power. The missile's ability to deliver atomic weapons onto the enemy alone was well worth its incredible development costs. This information was paradoxical: missile technology could protect Americans from another war, but their development could lead to the very war that they were built to prevent. Perhaps this was apparent to policy makers when they assured the public that this new weapon was "the least likely to be used" and was being built primarily as a deterrent. ${ }^{34}$

Throughout their development, it became increasingly clear that missiles would be used not to fight war, but to prevent war. As early as 1956 an article in the Bulletin of Atomic Scientists predicted that strategic war would become "so dangerous and risky that [missiles] would be useless as a tool of national policy."35 Another speculated that,

\footnotetext{
34 "Missiles Away," pp. 52-56. This was precisely the argument used by the Army when it asked for a budget to accommodate a 1.5 million man ground force: "The world will probably succumb to an atomic stalemate, hence the U.S. will need a conventional army which for maximum efficiency will need its own air arm." The Army was granted its request. "Decision on Missiles," Time, December 10, 1956, p. 25. The Bulletin of Atomic Scientists described the technological acceleration of the last decade a "Quantum Jump." Hanson W, Baldwain. "The New Face of War," The Bulletin of Atomic Scientists 12 (May 1956): 153-58.

${ }^{35}$ C.W. Sherwin, "Securing Peace through Military Technology," The Bulletin of Atomic Scientists 12 (May 1956): 159-164.
} 
"missiles may cease to be regarded as weapons entirely." Instead they "may become simply machines to keep international peace." It was thought that his would eventually lead to missiles to be "taken for granted and [they would] no longer attract attention.,"36 Despite emphasis as a deterrent, what drew most attention was the missile's destructive power.

By spring 1956, the race for a missile that could travel half way around the world was attracting international attention. This race was underscored during the visit of Soviet Premier Nikita Khrushchev to Great Britain. Khrushchev exclaimed to Prime Minister Anthony Eden's wife that the Soviet Union would soon possess guided missiles that would have a "very long range" and could easily reach England and "quite a bit farther." 37 American press reporters interpreted this to mean "the Soviet Union would soon possess guided missiles with H-bomb warheads capable of hitting every point or any point in the world," and they swarmed the White House for verification. While the press buzzed with questions, President Eisenhower attempted to quell speculation. He informed reporters that there was no reason to doubt Khrushchev, but it was important to differentiate between the capacity of doing something and actually having an "efficient, effective instrument of war." 38 In other words, the Soviets were likely exaggerating their

${ }^{36}$ Warren Amster, "Design for Deterrence," The Bulletin of Atomic Scientists 12 (May 1956): 164-165.

${ }^{37}$ Nikita Khrushchev, Khrushchev Remembers, translated by Strobe Talbot, (Boston, 1970), pp. 404-405.

38 Dwight D. Eisenhower, "President's News Conference of April 25, 1956," Public Papers, 1956. (Washington D.C.: GPO, 1958), pp. 428-29. 
missile achievements. This argument would be repeated by various officials with each Soviet missile declaration - until the launching of Sputnik.

On August 21, 1957, the Soviet Union revealed it had successfully tested a ballistic missile. From Kazakhstan the "world's first" ICBM was launched over the Pacific Ocean traveling more than 4,000 miles. ${ }^{39}$ Although information was limited, this announcement heightened public concern. But President Eisenhower, the press reported, "did not appear especially disturbed by the reports of Soviet progress," nor did he immediately address public fears. ${ }^{40}$ Messages from officials were mixed, but Americans were told that although the Soviets had tested a missile and the United States had not, the Russians were not "ahead." ${ }^{, 41}$ Adding to public anxiety was the resignation of Trevor Gardner, the assistant secretary of the Air Force (and one of the pioneers of the missile program) because he was "denied the kind of backing which would enable the U.S. to

${ }^{39}$ John Lewis Gaddis, We Now Know (New York, 1997): 238.

40 "Is the Worst True?" Newsweek, February 20, 1956, pp. 28-29. Again, Symington spoke up regarding the nation's missile program: "The President is badly informed if he believes this country could not move faster in the missile field." p. 29.

41 "Is Russia Really Ahead in the Missile Race?" U.S. News and World Report, May 4, 1956, pp. 34-45. According to authorities: Eisenhower told the public that it would take time to work out the "secret" of the missile (not dissimilar to the "atomic secret" argument); Chief of Staff of the United States Air Force, General Nathan F. Twining said that there was nothing the Soviets could do that the Americans could not: Director for Central Intelligence, Allen Dulles said that Khrushchev exaggerates; General Thomas S. Powers, Chief of SAC, noted that U.S. technicians are better; Secretary of Defense, Charles E. Wilson argued that Russia may advance, but the U.S. leads.

The successful launch of the Russian R-7 missile actually initiated a "space race" on the part of the Soviet Union. Khrushchev urged Sergei Korolyov (leading Russian rocket scientists) to launch the Soviet satellite "without delay" because Americans have almost reached their goal of launching a rocket and this was the opportune time to "outstrip them," Sergei N. Khrushchev, Nikita Khrushchev and the Making of a Superpower, translated by Shirley Benson, (University Park, Pennsylvania, 2000), p. 249. 
keep ahead [in the missile race]. ${ }^{, 42}$ This prompted the press coverage of the missile race to take a new tone of urgency.

Once again fear that there was no defense against the ICBM heightened public concern. The United States had been "forced into a missile race with the Soviet Union," declared an article in The Reader's Digest. Time was of crucial importance because "against such a missile no defense is in sight, no restraint except fear of retribution; and our power to retaliate will of course be unequal if the Russians achieve the missile before we do." ${ }^{, 43}$ As a result of the successful Soviet ballistic missile launch, Defense Secretary Charles Wilson announced that he would appoint a missile "czar"- an unusual title given the circumstances - to run a crash missile program comparable to the Manhattan Project. ${ }^{44}$ By the end of September, the United States successfully launched a missile from Cape Canaveral, Florida, but it was not guided and the launch was little publicized. ${ }^{45}$ Americans were left wondering about the vulnerability of their cities from Soviet attack and the role the missile would play in the next war. Some cities had a ring of defensive Nikes, but long-range missiles tested by the Soviet Union could penetrate that protective shield.

The image of the missile penetrated everyday life for Americans. Beginning in the mid-1950s, large companies used its image in advertisements to promote their products

42 "U.S. Races for a Supermissile," Life, February 20, 1956, p. 22.

43 “Guided Missiles: Key to Peace?" The Reader's Digest (March 1955): 17-23.

44 "U.S. Races for Supermissile."

45 “A U.S. Army Missile Leaps 3,000 Miles," Life, November 5, 1956, p. 119. 
by associating security with technological superiority. Douglas Corporation advertised its contribution to American defenses by linking itself with the Nike Ajax. Advertisements promised Americans that they were protected by the company's products. "Already key cities have the protection of a guided missile which can destroy the swiftest stratospheric bombers. . . Douglas leadership in rocket airframe design has helped give us operational missiles in a relatively short span of time. Security cloaks even greater advances that are now on the way." 46 The image of the missile, however, was not limited to a defensive role. Some corporations used the weapon to portray its destructive capabilities.

As the missile gained preponderance in national defense, the image of the weapon changed in advertisements. Companies began to use the missile to demonstrate power, rather than protection from attack. These advertisements also were placed closer to the front of magazines - eventually being placed on the first page. Goodyear epitomized this new direction in advertising with multiple, large, two-page colored ads. Advertisements were often very patriotic and used familiar images associated with security and nationalism. One in particular is dominated by a bald eagle holding a shield and what appears to be an olive branch. Readers are asked: "What does it take to create a complete Missile Weapon System?" Within the shield is the definition of a weapons system as defined by Defense Department regulations. In stars surrounding the dominating image are pictures of new technologies: different missiles, radar, delivery equipment, computers, and engineers. ${ }^{47}$

46 "Missiles by DOUGLAS," Douglas ad, Time, December 7, 1954.

47 "What does it take to create a complete Missile Weapon System?" Goodyear ad, Newsweek, October 14, 1957, pp. 68-69. The definition reads: "A system composed of 
In another advertisement, Goodyear illustrates the importance of the missile to protecting soldiers on the front line. In this illustration is a missile convoy in motion driving over rough terrain away from the viewer. The last truck (in the foreground) is carrying bright yellow missiles and in the background missiles are already stationed and appear ready for launch. Giving itself credit for missile squadron logistics, Goodyear told readers that, "thanks to a complete ground support system conceived and engineered by Goodyear Aircraft Corporation, missile squadrons have more 'hustle'-require a fraction of the muscle — and have achieved this increased mobility and efficiency at considerable savings of defense dollars. ${ }^{, 48}$ In other words, this new technology saves precious time, money, and manpower, resulting in saved lives.

Eventually, the missile became the only image in Goodyear ads. On the first page of Newsweek, a stark illustration of a missile is launched right past the reader (the angle is such that it feels like it is going to fly over your shoulder, with the firing site in the lefthand bottom corner). In bold letters: "DESTONATION: KINGDOM COME." The tone of this advertisement was much more hostile than in previous advertisements. Readers were told, "America's guided missiles stand ready to seek out and blow any marauder to

equipment, skills and techniques, the composite of which forms an instrument of combat, usually. . . having an air vehicle as its major element. The complete weapon system includes all related equipment, material, services, and personnel required for the operation of the air vehicle ... so that the instrument of combat becomes a self-sufficient unit of striking power within its intended operational environment."

48 "How to give a Missile Squadron twice the hustle with half the muscle," Goodyear ad, Newsweek, July 15, 1957, pp. 54-55. 
'kingdom come.",49 This advertisement demonstrated the increased importance placed on automated technology and the centrality of the missile as a symbol for corporate America. Simultaneously, man was increasingly shadowed by new technology-except for pushing a button, his image eventually was eliminated in advertisements. It appeared that his role would also diminish on the battlefield as missiles developed. The missile was the ultimate weapon and knowledge of it was brought to most American homes through illustrations in company advertisements. They were easy to read and often only contained familiar symbols and few words. The missile represented technological prowess, patriotism, and destructive power. As a symbol, Americans became vested in its development, which amplified its importance. These advertisements helped to strengthen the importance of achieving missile superiority before the Soviet Union.

To comfort readers about missile technology and humanize America's ICBM program, Life ran a feature in its spring 1957 issue on Major General Bernard A. Schriever, head of the Air Force ballistic missile program. The opening lines described the missile as "a rocket-launched projectile that will carry a thermonuclear bomb 5,500 miles through outer space to enemy targets." This statement simultaneously told readers of the missile's ability to protect them and of enemy capabilities against them. Security, the article stressed, came from deterrence and not missile defense. Schriever, America's

49 "Destination: Kingdom Come," Goodyear ad, Newsweek, November 18, 1957, p. 1. Lockheed also had an advertisement on the first page of Newsweek. Incorporating attack scenarios mentioned in news reports, readers are warned, but than assured: "Sneak attack by missile-carrying enemy submarines is a growing menace. . . . [but because of the Navy's P3V-1 Electra, built by Lockheed] The world's seas will no longer be a safe haven for lurking enemy submarines." A small illustration on the bottom shows a submarine being blown up. "Trackdown. . . Electra/ Style!" Lockheed Aircraft Corporation ad, Newsweek, August 4, 1958, p. 1. 
"top U.S. missile man," told readers that the missile was important because "it was the ideal deterrent," making it "the weapon most likely not to be used." Schriever underscored the importance of the missile program to national security when he told readers that the current pace of the project "already dwarfs the gigantic A-bomb Manhattan Project." ${ }^{, 50}$ In light of accelerated missile production and government prioritization, one could only question how missiles could not be used. By the end of the summer, it did not matter how large or centralized the missile project had become: on September 7, the Soviet Union claimed it had perfected the ICBM.

Again, reporters asked officials if the declaration was true and if "Russia [was] ahead in [the] Missile Race?" Military leaders told U.S. News and World Report that Soviet claims were doubtful. Military analysts scrutinized the carefully worded Soviet announcement and proclaimed there was much more to perfecting an ICBM than having a successful launch. Regardless of their assurances, a dramatic picture of a map of the United States and Canada accompanied the article with arrows and missiles shown arched over the North Pole with the entire United States as their target. The caption read: "With a 5,000-Mile Missile-Russia could reach any target in U.S." The article, however, refuted the visual imagery that accompanied it, arguing that the United States was superior in mass production, which also made it technologically superior. Acting Secretary of Defense Donald A. Quarles voiced the "prevailing [official] attitude": "The

50 "The Most Important Job in the U.S. Today," Life, April 29, 1957, p. 114. Reflecting back on the Missile Race, Schriever admitted to knowing about the U-2 over flights of the Soviet Union. "They were well ahead of us with the IRBM, at least a year ahead in their ICBM program. A missile gap did exist." He maintained that the Soviet failure was in their production: "They failed to meet the production schedule of which they were capable." "A Decade of Deadly Birds," Time, May 22, 1964, p. 25 
immediate military significance of the so-called race has been greatly exaggerated. $" 51$ This comment was obviously meant to alleviate public fears by minimizing the importance of the missile race and possible U.S. failure to "win." But it was too late to dispel public concern about such a race. Americans had been reading about it steadily for almost seven years and each Soviet announcement heightened public anxiety.

Within days, suspicions were confirmed that the Russian had successfully tested an ICBM. According to Newsweek, U.S. intelligence admitted to knowing for several months that the Russians "had fired at least four, and possibly six ICBMs."52 The magazine published headlines of newspapers throughout Europe demonstrating the international impact of the Russian intercontinental ballistic missile. Initially there was substantial horror, but again Quarles told the press that at least three more years would pass before the missile could be mass-produced by the Russians or the United States, attempting to level the scientific achievement of both countries. The Russians only tested a "prototype," Americans were told, and the United States was very close to testing its own. "The Soviets had won the first lap in the race to build an ICBM," proclaimed Life. But the magazine attempted to assure readers of the successful American missile program by running a two-page spread of the impressive array of all U.S. missiles on handincluding those not yet declassified. ${ }^{53}$ U.S. News and World Report also diminished the

51 "Is Russia Ahead in Missile Race?" U.S. News and World Report, September 6, 1957, pp. 30-32.

52 "Dawn of the Super-Missile," Newsweek, September 9, 1957, pp. 43-46.

53 "Mighty Red Missile," Life, September 9, 1957, pp. 39-41. The missiles that were not declassified were sketched white against a black background. Only their shape and size were hinted at. 
Soviet achievement by arguing the ICBM was not yet a threat because it was still in the developmental stages and contended the United States could out-maneuver the Russians with strategic bombers. In fact, the United States was so scientifically advanced, it was argued, that military studies had already confirmed that there was defense against missiles. ${ }^{54}$ The real threat of the Soviet missile launch, readers were warned, was psychological: "That the Soviet ICBM threat would frighten America's allies into giving up defense commitments and drive the U.S. into involuntary isolation." ${ }^{\text {,5 }}$ The magazine implied that Americans should not fall prey to Soviet propaganda. ${ }^{56}$

On October 4, 1957, the USSR launched the first artificial satellite into space. Sputnik was not only a Russian first for space science; it was a demonstration of missile power, for the satellite rode atop an intercontinental ballistic missile. Life showed pictures of Americans looking skyward, analysts hunched over tables, scientists examining radartracking screens, and armed guards, all reacting to the Soviet achievement. One full page

54 "How U.S. Will Block Russia's Missile," U.S. News and World Report, September 13, 1957, pp. 45-48; "A High Source Says: 'Russia's Missile Can be Stopped," U.S. News and World Report, September 13, 1957, p. 49. This article contained some of the first "anti-missile missiles" arguments.

55 "Dawn of the Super-Missile," Newsweek, September 9, 1957, pp. 43-46. It is also here that Symington expanded his missile argument to include the possibility of "Soviet 'ballistic blackmail."” p. 44.

56 The susceptibility of American allies to misinformation was a very real fear of the Eisenhower administration. Eisenhower hoped to use missile psychology against the Soviet Union. If the United States could not yet match Russia in long-range missiles, it could use carefully placed intermediate missiles as a deterrent. Much discussion went into how both American allies and neutral countries would react if the Soviets developed an ICBM or an IRBM before the United States and visa-versa: each scenario was evaluated. Memorandum of Discussion at the $258^{\text {th }}$ Meeting of the National Security Council, Washington, September 8, 1955, FRUS, 1955-1957, 19: 111-122. 
depicted the earth surrounded with the pattern of Sputnik orbits over a twenty-four hour period, implying that no area on earth was impenetrable from Soviet observation. ${ }^{57}$ Earth's new "traveling companion" was twenty-two inches in diameter and weighed 184 pounds-an impressive achievement. ${ }^{58}$ Because of the thrust needed to place a satellite of such weight into orbit, Western scientist were certain that the Russians had successfully developed an intercontinental ballistic missile. The feat stunned the world-but not the White House, which kept comments to a minimum. ${ }^{59}$

When President Eisenhower was questioned about the lagging satellite program of the United States, he responded that while the Soviets might have the advantage, the American satellite would be better. ${ }^{60}$ But the American public wanted to know how the United States had fallen behind. The President did not believe there was a missile race: the satellite project of the International Geophysical Year was a collaborative scientific effort with little sense of urgency. Past official reports calmly assured Americans that the

57 "The Feat that Shook the Earth," Life, October 21, 1957, pp. 19-29.

${ }^{58}$ This was especially the case when compared to the U.S. satellite in development for the celebration of the International Geophysical Year. The satellite designed by the United States only weighed 21 pounds. Because the American satellite was so much smaller than Sputnik Khrushchev often mocked its size.

59 Dwight D. Eisenhower, The White House Years: Waging Peace, 1956-1961 New York, 1965): Chapter 8. While reflecting back on the Sputnik account, Eisenhower was still puzzled by the American reaction. He noted past references by the Russians about their intent on building a satellite and commented that Americans should not have easily dismissed their intentions. However, there was almost no reference to Soviet science and satellite intent in contemporary literature. Only the best read would have been privy to this information. Therefore, the "near-hysteria" mentioned by Eisenhower was justifiable.

60 "The Feat that Shook the Earth," p. 25. The picture shown is one of a dumbfounded Eisenhower. 
United States was ahead in the ICBM race and that there was nothing to worry about, but news magazines continued to report the opposite. U.S. News and World Report told its readers the Soviet achievement was frightening. Reminding Americans of the London bombardment by German missiles in World War II, readers were warned that the next war would be one fought with rockets:

At 6:43 p.m. on September 8, 1944, a bomb fell without warning upon London. Sixteen seconds later, another bomb struck. Nothing was seen, nothing was heard to give any sign of their coming. Nothing could be done to stop the bombs, or to dodge them. There was no way to fight back.

British people that night faced a new form of terror. That same terror now confronts the entire world. . . the next war, scientists now are predicting, will be fought with rockets.

... When a nuclear bomb hits a city, it's not just a building or a block that's destroyed. The entire city is wiped out. ${ }^{61}$

It was time for Americans to face the new technological threats of the Nuclear Age. The Cold War thus far was an ideological battle, but had transformed to "a life and death struggle." An editorial in Newsweek argued that if anything could be gained from the Sputnik launch, it was to "shake [the United States] out of complacency." ${ }^{2}$ The article argued that the public needed to hold officials accountable for the technological failures of the United States.,

Henry Hazlitt of Newsweek faulted the United States government for the Russian achievement by attributing Sputnik to successful Communist infiltration and Soviet spy rings in American scientific circles. He argued that Sputnik did not prove Russian

\footnotetext{
61 “A Look at Rocket War," U.S. News and World Report, October 18, 1957, p. 46.

${ }^{62}$ Henry Hazlitt, "The Economic Consequences of ICBM," Newsweek, October 2, 1957, p. 94
} 
"physicists and military-weapon technicians" were ahead of their American counterparts. Russian success, he argued, was the result of American scientific publications-implying stolen secrets and Soviet incompetence. ${ }^{63}$ Hazlitt continued this degradation of Russian science a month later when he falsely recounted the Russian capture of Preenemünde. "They stripped it, took over every German scientist and technician that they could, and secretly ordered them to keep developing rockets and extending their range. The fatal atomic and nuclear warheads, they stole from us." ${ }^{64}$ The United States was not behind in scientific know how, but it appeared to be because of its inability to contain military secrets.

Sputnik prompted many officials to degrade Soviet scientific ability-perhaps to boost that of the United States. Another article similar to Hazlitt's wrongly attributed Russian missile success to their capturing "the entire [German] V-2 development with most of its scientists. ${ }^{, 65}$ Even President Eisenhower doubted Soviet scientific capability.

${ }^{63}$ Ibid. Hazlitt wrote: "We divorced our earth satellite project from our military ICBM efforts, divided responsibility for it, overlooked its huge propaganda potentialities, talked and boasted freely, and published our planned techniques in detail. The Russians read what we published, but published practically nothing themselves, and secretly drove ahead. The 'cooperation' on the 'International Geophysical Year' was all one way. In addition, the Soviets have kept us infiltrated with spies." Past stolen secrets would include both the atomic and hydrogen bombs.

${ }^{64}$ Henry Hizlitt, "Message of the Sputniks," Newsweek, November 18, 1957, p. 117.

65 "Guided Missiles: Key to Peace?" The Reader's Digest (March 1955): 17-23. In fact, in 1959, a Congressional Hearing was dedicated to the authenticity of Soviet space technology. Lloyd Mallan, of True magazine and author of "The Big Red Lie," claimed the Sputniks and the Lunik were Soviet fabrications. U.S. Congress, House, Hearings Before the Committee on Science and Astronautics and Special Subcommittee on Lunik Probe U.S. House of Representatives. $86^{\text {th }}$. Congress, $1^{\text {st }}$ sess., May 1959 (Washington, D.C., 1959), pp. 1-210. 
He questioned his scientific advisors if the Russians obtained thermonuclear weapons from secrets they obtained from the United States. ${ }^{66}$ A communist society's ability to scientifically outpace the United States was repeatedly questioned. U.S. News and World Report blatantly asked "Did Russia steal satellite secret from U.S.?" and reminded readers of past Soviet spy rings within the United States. ${ }^{67}$ Not everyone was reassured by these claims, however. The Bulletin of Atomic Scientists argued that the Soviet Union had a successful track record of rapid weapons development and that the United States should not underestimate its ability nor become complacent. ${ }^{68}$

In response to the Soviet success, the U.S. military attempted its own propaganda campaign by testing a "gaggle of missiles" only a few weeks later. Rather than continuing the missile secrecy, the Pentagon was willing, "even eager to tell about [missile] experiments." This would be a major issue in the history of the missile-the

${ }^{66}$ Eisenhower was assured by Niels Bohr that Soviet scientists did not steal secrets, but rather "checked their line of development against the data they obtained" from the United States. Memorandum of a Conference with the President, White House, Washington, October 29, 1957, FRUS, 1955-1957, 19: 615-617.

67 "Did Russia Steal Satellite Secret from U.S.?" U.S. News and World Report, October 18, 1957, pp. 44-45. After implying that American satellite secrets were stolen by Soviet spies, in the last pages of the same issue, there was a report on Soviet scientists and their rigid training and devotion to both science and the Soviet cause: "Behind Russia's earth satellite and long range missile: mass production of scientists by the Soviet school system. In the U.S.S.R. the importance of becoming a scientist is stressed from the earliest grades up. The typical production of this system is young, absorbed in his work, given much freedom to follow his won scientific bents. He is well paid, a member of a specially honored group. The goal of this scientist and his fellows is to outstrip the U.S. in achievements and make Soviet science the world's best." "A New Power for the World to Recon With," U.S. News and World Report, October 18, 1957, pp. 114-116.

${ }^{68}$ Henry M. Jackson, "The Increasing Threat of Ballistic Missiles," The Bulletin of Atomic Scientists 12 (March 1956): 90-92. 
strategic value of secrecy versus the public relations value of openness. Unfortunately, efforts to promote American missile experiments could not "detract from the impressive power of the Russian rocket which launched sputnik." ${ }^{\text {"69 }}$ The Soviet Union continued to take advantage of their lead in the missile race.

Before Americans could get over their shock and fear of the Russian triumph, Sputnik II was launched on November 2, less than a month later. A feature article in Life showed the Communist country celebrating triumphantly at the fortieth anniversary of the Bolshevik Revolution. Adding to the sense of American inferiority, the magazine included pictures of the Soviet display of arms. The "massed missiles," were equal in number to those possessed by the United States, readers were informed. ${ }^{70}$ That same week the cover of Newsweek displayed a satellite orbiting the head of a smiling Khrushchev, and declared, "no one could doubt [Nikita Khrushchev] any longer." The superiority of Russian missile technology seemed to be confirmed by the size of Sputnik II. Weighing 1,120.26 pounds, it could only have been launched into space by a powerful ICBM. This news of a second satellite did not ruffle President Eisenhower, who remained

69 "But No Sputnik-Yet," Newsweek, November 4, 1957, p. 66. Life noted that in response to the Soviet success, the United States launched missiles "with a vengeance," firing the "most missiles and rockets ever tested in one week." "U.S. Tries Hard to Catch Up," Life, November 4, 1957, pp. 27-34.

70 “A Birthday Flexing of Red Biceps,” Life, November 18, 1957, pp. 35-39.

71 “Can the U.S. Catch Up?” Newsweek, November 11, 1957, pp. 35-36. 
"calm, measured, without a hint of panic," but it did disturb Americans causing many to question the role of science in the education system. ${ }^{72}$

The press now changed course and showed a new respect for Soviet scientists. Newsweek noted that Lenin had often linked Communism with science. Rather than thinking scientific advancement was unachievable in a totalitarian society, readers were told, it should be recognized that "Russia's scientists are scientists first and hardly politicians at all." Often accompanied by perks "science is one of the most desirable fields in Russia." Instead of condemning the Soviet achievement, it was argued, the United States should examine its own educational system. In seven short years the Soviet Union increased graduate output of scientists and engineers fourfold-twenty percent of which were women-compared to a ten percent decrease in the United States over the same period. ${ }^{73}$ The situation forced Eisenhower to address the nation and to re-evaluate scientific and military collaboration efforts. ${ }^{74}$

${ }^{72}$ Ibid. The official magazine of the Parent Teacher Association (PTA) ran a series of articles about the Soviet Union, Communism, and education. The organization took up the challenge of attaining scientific superiority in American schools, and articles in their magazine compared the American system to the Russian. An example of articles that clearly reflect their view are: Herold C. Hunt, "An American Educator Views Soviet Education," National Parent-Teacher: The PTA Magazine, December 1958, pp. 4-6; Herold C. Hunt, "Visit To Russia: The Nature of the Soviet Challenge," National ParentTeacher: The PTA Magazine, January 1959, pp. 8-11; Edgar Collins Bain, "Russian Lesson for Americans," National Parent-Teacher: The PTA Magazine, June 1959, pp. 24-25; J.C. Moffitt, "Children, Parents, and Schools in Soviet Russia," National ParentTeacher: The PTA Magazine, May 1960, pp. 10-12.

73 "Sputnik II: The Surge of Soviet Science," Newsweek, November 11, 1957, pp. 73-74. Eugene Rabinowitch of The Bulletin of Atomic Scientists argued that the Russians have always been ahead of the Americans in "many areas of applied mechanics," and it was "ridiculous to seek the explanation for Soviet Rocket success in the capture of German specialists." In addition, he continued, the success of the American rocket program was a result of "German rocketeers." Eugene Rabinowitch, "After Missiles and Satellites, 
On November 7, 1957, the same day that the Russians celebrated their "military might" in Red Square, President Eisenhower addressed the nation to validate the American missile program and to buttress American scientific and technological superiority. To support his claims, in his office was a nose cone of an experimental missile, which the President maintained had been "hundreds of miles into outer space and back. Here it is . . unharmed" ${ }^{, 75}$ Throughout the address, the President held firm and encouraged Americans to do the same. The satellite achievement of the Soviet Union did not pose a direct threat to the United States, he argued: its launch vehicle was the real threat. "It is my conviction, supported by trusted scientific and military advisors, that,

What?" The Bulletin of Atomic Scientists 13 (December 1957): 346-350. The state of American education had already been examined and compared to that of the Soviet Union in 1955 by the U.S. government. The Office of Defense Mobilization reported "the Soviets are continually expanding their educational facilities for the training of scientists and engineers. They are now graduating such persons in considerable greater numbers than the U.S. The best of their graduates are fully the equal of our best, and there is evidence to show that the top administrators of Soviet research and development are first class scientists." Report by the OMD-Defense Working Group, "Achieving and Maintaining U.S. and Free-World technological Superiority over the U.S.S.R." Washington, December 20, 1955, FRUS, 1955-1957, 19:173-177.

${ }^{74}$ Despite this challenge, U.S. News and World Report was still asking if the U.S. could win the missile race. According to a "top missile expert," the Russian satellite did not involve "'real' scientists,"-portraying the Russian success as insignificant. "Can U.S. Still Win Missile Race?" U.S. News and World Report, November 15, 1957, pp. 104-108. When interviewing Fred Singer (long-range missile consultant for Avco Research Laboratory and advanced satellites for Martin Company), it was asked if he believed that "tremendous scientific teamwork" was used to produce Soviet results. He answered: "I do not think it has included what I call 'real' scientists, in the sense of scientists who do new, basic research and produce new results about the universe and about physics. They have not participated very much in the missile and other programs." p. 108.

${ }^{75}$ Dwight D. Eisenhower, "We Could Fall Behind-Unless We Face Up to Job," U.S. News and World Report, November 15, 1957, pp. 144-147. This was a printing of the Presidential speech of November 7, 1957. 
although the Soviets are quite likely ahead in some missiles and special areas, and are obviously ahead of us in satellite development, as of today the over-all military strength of the Free World is distinctly greater than that of the Communist countries." ${ }^{\text {76 }}$ The reason for the President's confidence was not declassified until a few years later, when a U-2 spy plane was shot down over Russian territory. The United States had been conducting clandestine flights over the Soviet Union. These flights kept the U.S. government well informed of Russian defense developments. ${ }^{77}$ At the time of this speech, however, the President was unable to disclose the information gathered by the U-2 flights. Instead, his lack of evidence concerning American scientific superiority gave credence to a "missile gap.,"78

To quell continuing fears the President addressed the nation again a week later in Oklahoma. The United States was investing large sums of money in missile research and development, Eisenhower assured listeners, but he shifted the blame from the government to the public. Like Newsweek so recently argued, Eisenhower noted that it was the responsibility of the American people to oversee the role of education in national defense. The United States was behind the Soviet Union in producing scientists and

${ }^{76}$ Eisenhower, Waging Peace, p. 224.

77 Philip Taubman, Secret Empire: Eisenhower, the CIA, and the Hidden Story of America's Space Espionage, (New York, 2003).

${ }^{78}$ Espionage was an integral part of the New Look policy. Eisenhower believed that Soviet actions made "clandestine activities" necessary, but the U-2 incident was something the President took precaution to avoid. Although sorry for Francis Gary Power's capture, Eisenhower never regretted his decision to conduct the U-2 flights. Dwight D. Eisenhower, Waging Peace: the White House Years, A Personal Account, 1956-1961, (New York, 1965), pp. 550-559. 
engineers. The President proclaimed 1957 Education Year and American citizens were called upon to make this "one single project their special order of business." ${ }^{, 79}$ Soon after, U.S. News and World Report described the Soviet school system and showed that the American system just did not compare. ${ }^{80}$ Americans accepted the challenge and looked to the scientific community for leadership.

By mid-November Life presented Wernher von Braun on its cover beside a "moon rocket model" inviting Americans to support a new scientific endeavor: putting men into outer space. ${ }^{81}$ The "American" German missile expert was hailed "The Seer of Space" by the magazine. ${ }^{82}$ To "catch up" with the Soviets in engineering and science, the United States not only had to increase development and output, but it needed to excel in missile technology. A space success, it was believed, would also enable the missile to be used for

${ }^{79}$ Eisenhower, "Radio and Television Address to the American People on 'Our Future Security,' November 13, 1957," Public Papers, 1957, pp. 807-816. In polls taken shortly after the "Sputnik shock" it was apparent that a large majority of Americans were willing to see heightened standards for science, math and foreign languages. Gabriel A. Almond, "Public Opinion and the Development of Space Technology," Public Opinion Quarterly (Winter 1960): 568. The PTA took this assignment from the President personally, and printed a pamphlet addressing the issue. Mrs. Rollin Brown, "Reprinted from the National Congress Bulletin," Pamphlet, National Congress of Parents and Teachers, February 1958. National Congress of Parents and Teachers, PTA Archive.

80 "The 3 R's in Russia Are Really Tough," U.S. News and World Report, November 15, 1957, pp. 137-141. By 1964, however, another evaluation of the Soviet School system was made, and it was declared that they did not measure up to their counterparts in the United States! "Is Russia's School System So Good After All?" U.S. News and World Report, February 3, 1964, pp. 70-71.

81 "Destination, Outer Space-A Primer on Propulsion and Fuels," Life, November 18, 1957, pp. 44-46."

82 "The Seer of Space: Lifetime of Rocket Work Gives Army's von Braun Special Insight into Future," Life, November 18, 1957, pp. 133-137. 
peaceful purposes. Americans needed to put men in space and possibly on the moon to surpass the Russian satellite achievement.

Wernher von Braun was the man Americans expected to make this dream a reality. Long a proponent of space, von Braun told the Senate Preparedness Subcommittee (investigating why the United States "lost the missile race") that the real importance of Sputnik was that the satellite could "spy on the world, drop bombs on the U.S., 'saturate' the U.S. defensive radar systems and make it impotent." In other words, satellites could be used for clandestine purposes and transform space into a weapons theater, directly contradicting the President's November 7 speech. ${ }^{83}$ When the United States finally launched its own satellites into space at the end of January 1958 and twice more in the beginning of spring, U.S. News and World Report asked if the next step would be for men to go to space. ${ }^{84}$

It appeared that the United States had caught up to the Soviets in the space race, but Americans were still concerned about a possible missile gap. Stewart Alsop was one

83 "The Truth About Missiles: What Went Wrong," U.S. News and World Report, December 27, 1957, pp. 35-39. Also see: "America's Arsenal of Missiles," U.S. News and World Report, April 19, 1957, pp. 28-29; R. Rollefson, "Why So Many Missiles," The Bulletin of Atomic Scientists 13 (October 1957): 295-301. The end of 1961 showed these same fears of Soviet weapons in space: "Is Outer Space the Next Battlefield? Arms in Space: Something Else to Worry About." U.S. News and World Report, October 9, 1961, pp. 76-77. One capability that was not mentioned but must have been in the minds of military planners was the possibility of using satellites to properly map the globe. This was a recurring theme when questioning the U.S. ability for a successful retaliatory strike against the Soviet Union. Life complained that most of the Soviet Union was a "geographical question mark," and if the United States had to retaliate against a Soviet attack, it might not be able to find the ICBM locations. "U.S. Races for Super Missile," Life, February 20, 1956, p. 22.

84 “A Lot More 'Explorers' and 'Vanguards' on the Way," U.S. News and World Report, March 14, 1958, pp. 48-49. Explorer I was put into orbit January 31, 1958, Vanguard I on March 17, and Explorer II on March 26, 1958. 
of the first reporters to argue this possibility. He defined "The Gap" as "a period of deadly danger, when the Soviets will have operational ballistic missiles systems while we must rely on our manned-bombers." The Gap, he continued, "is either upon us or very nearly upon us." Alsop blamed The Gap on two factors: the slow missile start during the Truman presidency as a result of the atomic bomb monopoly "illusion" and the unrealistic accuracy requirements presented to American scientists during the current administration. ${ }^{85}$ The public, however, was learning that there was more to missile deterrence than the numbers of intercontinental ballistic missiles.

It was announced that the placement of IRBMs in European bases would cancel out the threat of Russian ICBMs. This was both a warning to the Soviet Union and a consolation to Americans. According to Time, the power of American IRBMs placed on the continent of Europe made up for the apparent deficiency of ICBMs, giving NATO "that big bang." By strategically placing missiles within and around the periphery of the Soviet Union, Eisenhower was meeting Khrushchev's challenge of "missile

${ }^{85}$ Stewart Alsop, "How Can We Catch Up?" The Saturday Evening Post, December 14, 1957, pp. 26-28. . The accuracy requirement was "One in ten thousand" which meant that a 5,000 mile range missile needed to hit its target within one-half mile. In comparison, the Soviets developed missiles earlier with a more "realistic" goal of five miles of error for a 5,000 mile missile. This made the missile seem more achievable, and also allowed the Russians to begin work on their missile program much earlier. According to historian Donald MacKenzie, this analysis is partially correct. Although both the Army and the Air Force placed high restrictions on the accuracy of ICBM development, they did so for different reasons. The Air Force, MacKenzie argues, required the ICBM to have a circular error probable (CEP) of 1500 feet, roughly equal to the CEP of blind high-flying bombers of the early 1950s. The Army, in contrast, required a stringent CEP to carry out tactical bombing requirements of a limited war. Donald MacKenzie, Inventing Accuracy: A Historical Sociology of Nuclear Missile Guidance (Cambridge, 1993), Chapter 3. 
diplomacy." multitude of points. . . The maximum massive retaliation remains in the crux" of American defense. ${ }^{87}$ U.S. News and World Report demonstrated this advantage to readers with a map. Rings of Strategic Air Command (SAC) bases circled the U.S.S.R. Each of these bases would soon get IRBMs, Americans were promised, and by placing them in the noted bases, missile deterrence would be complete. ${ }^{88}$

Perceptions began to change about American inferiority after November 1958, when the United States fired an Atlas 6,325 miles, providing "the psychological shot in the arm" that Americans needed. The missile gap had not closed, but it "had certainly been drastically narrowed." Equally important was the triumphant Atlas added to SAC's "mighty retaliatory [deterrent] strength." This success, Newsweek boasted, surpassed Russian missile know-how: "Russia never fired a full-fledged ICBM over a distance comparable to that spanned by the Atlas ... [and may not] have solved the problem of "nose-cone re-entry."' It appeared as if the Atlas would solve many problems plaguing national defense and American (in)security. ${ }^{89}$ This was a relief to readers who less than a year before were told of the inadequacies of SAC. ${ }^{90}$

86 "Missiles for NATO," Time, November 25, 1957, pp. 25-27.

87 Memorandum of a Conference With the President, White House, Washington, November 4, 1957, FRUS, 1955-1957, 19:620-621.

88 "Is the U.S. Really in Danger," U.S. News and World Report, January 10, 1958, pp. 4347.

89 "The Weapon to Wage Peace," Newsweek, December 8, 1958, pp. 21-22.

90 "The Truth About Missiles: What Went Wrong," p. 64. General Curtis E. Lemay, Vice Chief of Staff of the Air Force and former head of SAC informed Senator Symington that 
By the close of 1958 , the race for the ultimate weapon was in full throttle - with the United States forging ahead. "Balance of Power Tilts to U.S." declared U.S. News and World Report. Sixty Thor IRBMs were placed in Great Britain, and launch sites for the new Atlas ICBM were being constructed around the country. ${ }^{91}$ The Russian Sputnik III was sputtering in space in the company of three U.S. satellites better equipped than their Russian counterpart. As if the United States was making up for lost time, it doubled production of missiles and trained crews. Americans were informed that missiles were already in use victoriously battling Communists. In addition, a new and improved Nike had been successfully tested, proving its readiness to replace the already out-dated Nike Ajax. ${ }^{92}$ Most important to the missile race, however, was the development of the ICBM. Both the Atlas and Titan were already in production with the site selection process already under way. As development and deployment of first generation intercontinental

SAC was grounded for five weeks because of lack of gasoline for the planes. This was a result of budget restrictions in Fiscal Year 1956.

${ }^{91}$ The Thor (a 1,500 mile range IRBM) was a "stop-gap" measure implemented until the ICBM became operational. They were housed above ground, liquid fueled, and took fifteen minutes to prepare for flight. The Thor were completely retired by 1963 . Lonnquest, p. 268.

92 The first "battle-tested air-to-air missile, the Sidewinder, had recently helped National Chinese pilots to knock down 29 Communist MIG jets near Quemoy," an island off the coast of China. "Superweapons Race: Balance of Power Tilts to U.S." U.S. News and World Report, December 12, 1958, pp. 35-37. The Hercules was solid fueled with a range four times greater than the Ajax and could carry a nuclear warhead. Whereas public relation campaigns were conducted at Ajax sites, "essentially everything about the Hercules' nuclear warheads was strictly classified and off limits. Troops couldn't even acknowledge whether any such weapons were even present on bases," keeping the improved missile arsenal shroud in secrecy. Chiles, "Ring of Fire," p. 36. 
ballistic missiles advanced, new technology was accelerating the nation's missile program.

The Minuteman introduced the "next generation of missiles." They were smaller, lighter weight, and easily concealed within the ground. ${ }^{93}$ Whereas the missile was believed to be the ultimate weapon, the Minuteman was believed to be the ultimate missile-and therefore the ultimate deterrent. U.S. News and World Report excitedly announced that it "could be concealed in a small hole, [and] thousands could be dispersed around the country." Perhaps most impressive was its highly publicized push-button operation. "The button that sets the Minuteman winging toward its target could be pressed from a distance, by remote control" with only 30 minutes to target. This missile would drastically reduce warning time to a mere 15 minutes - a true deterrent to the enemy. ${ }^{94}$ Production on the Minuteman was moving so quickly that the Titan-the missile to bridge the Atlas and Minuteman — was threatened with cancellation. ${ }^{95}$ The American missile program was "catching up." Indeed, it was accelerating the speed with which war could be fought, making push-button war a reality.

93 The economic value of the Minuteman was apparent by a report by Secretary of Defense Robert McNamara to President Kennedy: "For the same cost as a wing of B-52's with tankers and Skybolts [mounted air-to-air missiles], we could buy 250 Minutemen hardened and dispersed, or 6 Polaris submarines." Draft memorandum From Secretary of Defense McNamara to President Kennedy, Washington, September 23, 1961, FRUS, 1961-1963, 8:138-165.

94 "Last Chance for a Deal to Stop Surprise Attack," U.S. News and World Report, December 19, 1958, p. 67.

${ }^{95}$ The Minuteman was mentioned the week before in Newsweek's "The Weapon to Wage Peace," but it was shielded in secrecy and represented with a question mark beside drawings of the Atlas and Titan. Also see: David K. Stumpf, Titan II: A History of a Cold War Missile Program (Fayetteville, Arizona, 2000). 
The United States appeared to have met the initial Russian ICBM challenge, but the public rhetoric of fear did not abate. There were still fears of a missile gap and new fears would surface about automation and push button weapons. The United States had functioning ICBMs, but the Russians probably had more. This assumption was based on three factors: the U.S. delay to get an ICBM before the Russians, Soviet ability to launch several satellites into space before the United States, and the time lead of the Soviets to achieve those two objectives. In addition, heated rhetoric was coming from the Kremlin elevating anxieties. The first week of 1960 brought Soviet warning of a "new and "more powerful' rocket" to be fired into a "specifically delineated area of the Pacific Ocean." 96 Compounding concerns about Soviet missile testing, Khrushchev's speech before the Supreme Soviet "went ringing round the world" when he mentioned a "fantastic weapon." Hitting on western concerns of a missile gap, Khrushchev said "we already possess [the] nuclear weapons ... and rockets to wipe out any country or countries which attack us off the face of the earth." This statement caught the West off-guard. ${ }^{97}$

In the coming election year, Newsweek predicted, "the question of missile strength would become of paramount importance." It was right. The press told readers of the men "haunted by doubts" about the competency of the retaliatory ability of SAC, and the threat a surprise Soviet attack resurfaced because of its "edge in missiles." Compounding public anxiety was the report of "widespread worry inside and outside the Pentagon" that Soviet advances in "air defense might largely cancel out SAC's bombers"

\footnotetext{
96 “The Red Rocket's Glare," Newsweek, January 18, 1960, p. 17.

97 "Power Struggle," Newsweek, January 18, 1960, p. 19.
} 
before the United States had a chance to close the missile gap. ${ }^{98}$ These speculations added to public unease that such a gap existed. For years the press bombarded Americans with reports about the nation's failure during the missile race, and there was no reason not to believe there was a missile gap. The United States, it appeared, had been slow to catch up. Even Congressmen believed there was a missile gap. Only a select few in Eisenhower's circle knew with certainty that there was a gap-but it was in the favor of the United States. ${ }^{99}$

American military leaders were racing to stop any gap. On February 11, 1960, it was announced that the Minuteman would be operational a full year ahead of schedule. To protect the missile from a Soviet preemptive strike, Minutemen were intended to be mobile. ${ }^{100}$ The Navy also had a solid fueled IRBM equivalent to the Minuteman: the Polaris. Launched from a submerged submarine it was both mobile and concealed. Soon there would be a whole fleet of nuclear submarines, which would contain sixteen nuclear IRBMs each. ${ }^{101}$

98 "The Coming Missile Gap: Power in the Bomb Bays; Trouble in the Pads," Time, February 8, 1960, p. 18. It was believed that the completion of the Minuteman in 1963-64 would close the missile gap.

99 Philip Taubman, Secret Empire: Eisenhower, the CIA, and the Hidden Story of America's Space Espionage.

${ }^{100}$ Liquid fueled missiles had several drawbacks: they were expensive, intricate, must be maintained regularly by a small crew of men, and they needed many hours of fueling time making them unable for immediate operation. In comparison, solid fuel missiles can be fueled in advance and stored indefinitely—ready for instantaneous lift off.

101 "It's Russia's Turn to Worry About the 'Missile Gap,"' U.S. News and World Report, February 22, 1960, pp. 45-47. 
U.S. News and World Report presented the Minuteman and the Polaris as reasons that the United States should not fear any supposed missile gap. ${ }^{102}$ If the Soviets scored points by being first, the American capitalist system would counter with its own hidden weapon-economic productivity. The Minuteman could be produced cheaply and would be widely distributed, negating any Russian advantage in size and thrust. Where first generation liquid propelled missiles were largely handmade, the Minuteman was the world's first missile capable of being mass-produced. "It is a missile we can afford to buy, not just in the dozens or in the hundreds, but in thousands, if need be." Because of this new technological innovation, it was predicted that the "gigantic liquid-fueled [Atlas and Titan] missiles and the manned bomber will begin, in the airman's jargon, to 'phase out." ${ }^{\prime 103}$ The Saturday Evening Post told Americans that they could deal with any missile gap by forging ahead in the "destruction gap"- the amount of destruction that can be inflicted upon the enemy—also known as "overkill." 104

102 "The Truth About Missiles," U.S. News and World Report, February 29, 1960, pp. 4251. Italics mine.

${ }^{103}$ Harold H. Martin, "Our New Generation of Rockets," The Saturday Evening Post, October 1, 1960, pp. 28-29. Although this missile was considered an economic relief for the Department of Defense (it was not only relatively inexpensive to make compared to previous ICBMs, but it required less ground support facilities also), The Minuteman missile system was complex and consisted of thousands of miles of cable beneath the ground to link the silos and launch control centers. "RCA is Awarded Contract for Air Force's Minuteman Missile," Titusville Star-Advocate, August 5, 1959, p. 3. Examples of this cable are displayed at the Minuteman Missile National Historical Site, National Park Service, at Philip, South Dakota.

104 "The Truth About the 'Missile Gap," U.S. News and World Report, February 27, 1961, pp. 41-43. This also became a hotly debated issue. Nuclear physicist Ralph Lapp wrote an entire book on the subject called Kill and Overkill, which is discussed in another chapter. Ralph E. Lapp, Kill and Overkill (New York, 1962). 
American ingenuity and mass production skills helped to quell public concern of Soviet missile achievements, but the so-called missile gap was largely fictitious anyway. U-2 flights over the Soviet Union informed President Eisenhower about Soviet missile shortcomings—-something Khrushchev desperately attempted to cover with fiery rhetoric and military demonstrations. This classified information never made it to the public or Congress, and as a result, the debates about the proper way to protect Americans from the threat of Soviet missiles continued.

Leaders of both sides continued the charade of a Soviet missile threat. The Kremlin wanted their countrymen and the world to believe they had the advantage in missile numbers, and the White House was not willing to disclose information obtained covertly. The charade ended May 5, 1960, when Khrushchev announced that the Russians had shot down a U-2 violating Russian territorial sovereignty. Eisenhower at first publicly denied the accusation because he wanted U-2 flights to remain confidential. He had to admit the truth, however, when he was told that the pilot, Francis Gary Powers, parachuted to safety and was taken as prisoner. ${ }^{105}$ This episode was embarrassing for both the Soviet Union and the United States. The former thought they were hiding missile inadequacies, and the later was accused of illegal acts of espionage that could have started war.

Eisenhower did not reveal information collected by the U-2 flights about the Russian missile program that indicated the United States was ahead of the Soviet Union. This secret information underscored the president's calm attitude while addressing national fears of a missile gap. Only a handful of people were informed about Operation

${ }^{105}$ LaFeber, p. 213. 
Corona. Even Congress was excluded from this knowledge, leading to presidential candidate John F. Kennedy's use of the missile gap as his campaign battle cry. Concern of a gap resonated with the American public who for years had been reading about national missile inadequacies and these fears helped Kennedy get elected. Once in the White House, however, the subject was dropped. Kennedy was informed of the information collected by operations, and he realized that the United States was leading in missile development. What had been the center of the presidential debates was no longer mentioned. Both the missile race and the missile gap were over. But new technological advances in missile development exacerbate an increasingly tense international situation. It was clear that the missile would continue to be the predominant weapon of the Cold War.

The rapid acceleration of technology in an increasing hostile and polarized world created a ripe environment for security concerns among the American public. Popular magazines helped to fuel these fears with regular articles about Soviet attack methods and advanced weapon systems while emphasizing American vulnerability and military inadequacies. The missile did not assure protection. In fact, it opened Pandora's box about national safety issues. Not only were Americans concerned about missiles raining down on American cities, they were also concerned that new technologies would negate previous safeguards. This created new safety concerns about instantaneous weapons. 


\section{Chapter 2}

\section{A Buck Rogers War}

Somewhere in the world there is a man, armed only with a pencil and a scrap of paper, who someday will figure out a way to blow up any city in the world simply by pressing a button.'

The acceleration in weapons technology increasingly alarmed Americans about the possibilities of accidental war and its catastrophic consequences. There were three distinct reasons for this. First, missiles relied on automation, which allowed for both a smaller defense budget and a minimal standing army. Second, civilians and non-military experts for the first time determined strategy in think tanks where they planned for national defense and nuclear war. Third, the apparent instantaneous ignition of missiles led to shortened reaction times and less time to protect civilian populations. This fear of accidental war as a result of push button technology is especially noticeable during the years 1957 to 1962 - the height of the missile development period.

Fantasies of science fiction have long dealt with the possibility of "push-button" technology. The first glimpse of this can be traced back to the mechanical marvels and gadgetry of H.G. Wells' "Time Machine" published in $1895 .^{2}$ This story became a catalyst for imaginative thought about science and technology. Contrary to popular science fiction of the time, Wells contradicted scientific optimism by using technology to

\footnotetext{
1 “Push-Button Defense?" Newsweek, May 2, 1955, p. 27.

${ }^{2}$ H.G. Wells, "Time Machine," in The Short Stories of H.G. Wells. (London, 1957), pp. 9-138.
} 
describe not the utopia that technologically advanced societies were suppose to create but the undoing of man and the end of the world. ${ }^{3}$ This theme was especially apparent in his The Last War: A World Set Free, which predicted civilization destroyed by atomic bombs. ${ }^{4}$ Science once thought to better society was being created and used for destructive purposes. Both world wars demonstrated that man had the capability to "pulverize civilization." Most believed that the next attack would come from the skies. ${ }^{5}$

Americans did not question missile development, but they did question the consequences of reliance on computerized controls for national defense. Imagined accidental war was a consequence of these changing technical and military landscapes. National defense was no longer confined to humans, but would involve computers launching weapons through space traveling at hitherto unheard of speeds. With projected target times of thirty minutes or less these new weapon systems would make America's oceanic borders irrelevant. ${ }^{6}$ Coupled with atomic or hydrogen warheads, the missile presented Americans with a different world, indeed.

${ }^{3}$ Mark. R. Hillegas, The Future as Nightmare: H.G. Wells and the Anti-utopians (New York, 1967), Chapter 2. The human attempt to unsuccessfully manipulate nature through science is clearly evident in The Island of Doctor Moreau. H.G. Wells, The Island of Doctor Moreau, (London, 1896).

${ }^{4}$ H.G. Wells, The Last War: A World Set Free [1914], (Lincoln, Nebraska, 2001).

${ }^{5}$ Spencer R. Weart. Nuclear Fear: A History of Images. (Cambridge, 1988), p. 26. Before 1914 "two-thirds of fictional apocalypses had been due to natural causes, after 1914 two-thirds were caused by humans, and of these, three-quarters of the doomsdays came in world wars with scientific weapons."

${ }^{6}$ The theme of accidental war was actually introduced before ICBM technology or automation of weapons of mass destruction. "Pilot Lights of the Apocalypse," a one act play, was printed in various periodicals beginning in January 1946. Written before the American development of missiles, it described a world filled with mines and satellite 
When the Truman administration announced the decision to build the hydrogen bomb, most Americans initially applauded the decision. Concerned scientists, however, feared the direction national defense was taking and made their voices heard on Capitol Hill and to the American public. ${ }^{7}$ Fears of the so-called "super weapon" soon trickled down to the ordinary citizen, as more information about the hydrogen bomb was published. Once people were informed of the destructiveness of thermonuclear weapons, they were not so certain of its necessity. ${ }^{8}$ Many Americans felt that the atomic bomb had been imperative to winning the war against Japan, but they were not as confident about the necessity of building such a massively destructive weapon as what was becoming known as the "Super." Americans had just learned of the effects of early atomic weapons

missiles that circled the earth, with all weapons activated at a "push of a button." Set in a military Defense Command Post, an earthquake turns the light of San Francisco "red," indicating that it had been attacked. Shortly thereafter, cities around the world also appeared red, as a chain reaction of bombing occured - one country pre-empting another. Louis N. Ridenour, "Pilot Lights of the Apocalypse," Fortune 33 (January 1946): 116.

${ }^{7}$ Americans did not become concerned with the development of thermonuclear weapons until scientists started voicing their concerns. In 1950, the majority of those asked by both The Gallup Poll and Public Opinion Quarterly responded that they believed the hydrogen bomb should be made. Of those people, the majority believed that the Soviets would use the bomb on the United States if they had the power to do so. But they also felt that the U.S. should attempt to work out an agreement with the Russians to control the atom. George H. Gallup, The Gallup Poll, vol. 2 (New York, 1998), pp. 894-895; "The Quarter's Polls," Public Opinion Quarterly 14 (Summer 1950): pp. 372-373.

${ }^{8}$ In 1954, The Gallup Poll discovered that "older people [50 and over] were more inclined to see the thermonuclear bomb as an instrument of peace than younger people" by more than a 3 to 1 ratio. This reveals a large percentage of Americans who increasingly felt that such technology was dangerous. $59 \%$ of those polled also believed that there was "much danger" of another world war. "War and the atomic bomb" were also among the top "personal fears" of those polled aged 21-29. And consistently thought at least 1962, the majority of Americans polled listed another war among their top concerns. George H. Gallup, The Gallup Poll, vol. 2 (New York, 1998), pp. 1255, 1267 
when they began to hear the apocalyptic predictions of thermonuclear weapons by the very scientists who were building them. ${ }^{9}$

As scientists were warning Americans about the effects of thermonuclear bombs, the government used information about atomic weapons generally: to create a climate of fear to garner public support for nuclear deterrence. ${ }^{10}$ A key component of defense doctrine in the 1950s was its emphasis on the psychological, used in foreign and domestic policy by both the Truman and Eisenhower administrations. The Truman administration used what Guy Oakes refers to as "emotion management" to convince Americans to support deterrence through civil defense. By encouraging citizens to think that they could survive a nuclear war with minimal advanced preparedness and simultaneously diminishing the effects of such a war, it was believed that Americans would support containment through deterrence." As John Lewis Gaddis notes, "Atomic bombs were

${ }^{9}$ Although John Hershey's book Hiroshima was published in 1946 and was widely read by the American public, its information about atomic effects on survivors was limited. Hiroshima's emphasis was on the shock, unpreparedness, and dislocation of the citizens - as was the information being fed to the American public at large. This limited information told to the public about the effects of radiation caused much debate among scientists. Indeed, morality was one of the main issues that so disturbed J. Robert Oppenheimer during the Eisenhower administration. John Hershey, Hiroshima (New York, 1946); Kai Bird and Martin J Sherwin, American Prometheus: The Triumph and Tragedy of J. Robert Oppenheimer (New York, 2005), pp. 416-484. It is important to note, however, that not all Americans agreed with the use of the atomic bomb. There were opposition groups-primarily religious organizations, who pointed to the ethical and moral questions of its use.

${ }^{10}$ Ira Chernus, "Operation Candor: Fear, Faith, and Flexibility," Diplomatic History 29 (November 2005): 779-809. The Administration's use of candor was, in effect, the exact opposite of what scientists suggested it be used for-disarmament.

${ }^{11}$ Guy Oakes, The Imaginary War: Civil Defense and American Cold War Culture (New York, 1994). Project East River, undertaken by Associated Universities, Inc., a think tank of Ivy League Universities, developed proposals that would enable the federal 
terror weapons as well as strategic weapons, and it was precisely their efficiency that was terrifying."12 The key to this argument, however, was that the public received limited information about atomic weapons and atomic war.

Like Truman before him, Eisenhower also believed that psychology should be used in conjunction with national and foreign policy. He understood the importance of language as a "discourse of danger" to "rationally control fear of nuclear war." 13 With carefully chosen words, Eisenhower was able to heighten American anxieties about the relationship with the Soviet Union while at the same time directing these fears to gain support for nuclear deterrence. Americans were willing to accept nuclear deterrence and were supportive of a missile program, but they became increasingly skeptical of

government to prepare American civilians for nuclear war. If Americans thought they could successfully wage and survive a nuclear war, it was believed they would support nuclear deterrence. The study concluded that "to domesticate the psychological warfare tactics that were employed against America's enemies abroad," propaganda "retooled as emotion management," should be used to psychologically manipulate the American public in the name of national security. In other words, the federal government could use propaganda domestically to both minimize panic and support civil defense planning which would thereby support national security policies. p. 51 .

\section{John Lewis Gaddis, We Now Know: Rethinking Cold War History (New York, 1997), p. 103.}

${ }^{13}$ Chernus, "Operation Candor: Fear, Faith, and Flexibility," p.784; 794. The use of discourse as policy was first expressed in the Oppenheimer Panel's idea of "candor." The openness proposed by the Panel was intended to enlighten the public about the dangers of nuclear weapons and thereby promote disarmament, but the Eisenhower administration used the policy of candor to make nuclear weapons more acceptable. Eisenhower did not use total honesty or disclose the facts about nuclear weapons to the public; in fact, while supporting the candor program, Eisenhower "never justified it, or even spoke of it, as a rout of disarmament. Because he wanted more candor in part to make nuclear weapons more useable, he was not likely to promote candor as a way to make the weapons unusable." This component of psychology coupled with discourse in foreign and domestic policy is important because its use in policy was not central until the Eisenhower administration. Ibid, pp. 792-793. 
defense's reliance on what they perceived as accident-prone automation. As missile defense became a reality, Americans became more frightened of technological mishaps. ${ }^{14}$

It was important for the Eisenhower administration to garner support for nuclear deterrence domestically while at the same time using deterrence to create "fear, anxiety, and doubt" in the enemy. ${ }^{15}$ To do this it was deemed imperative for Americans to continue to consider the Soviet Union a "direct military and political threat." "belief" in the enemy was crucial in the support of a domestic nuclear arsenal and became a major component in the public acceptance of the ballistic missile program, which in 1955 was given the highest priority by the National Security Council (NSC). ${ }^{17}$ Edward W. Barrett, the public relations expert and Assistant Secretary of State for Public Affairs during the Eisenhower presidency, urged the government to launch a "psychological scare campaign" to assure that the United States kept pace with the Soviet Union in the race for weapons supremacy. ${ }^{18}$ Thus, both the mental perceptions of weapons technology

${ }^{14}$ This period also coincides with the development of the Committee for a Sane Nuclear Policy (SANE) and the height of its popularity. Milton S. Katz, Ban the Bomb: A History of SANE, the Committee for a Sane Nuclear Policy, 1957-1985 (New York, 1986).

15 Dockrill, Saki, Eisenhower's New-Look National Security Policy, 1953-61, (New York, 1996), p. 48.

16 Kenneth A. Osgood, "Form Before Substance: Eisenhower's Commitment to Psychological Warfare and Negotiations with the Enemy," Diplomatic History 24 (Summer 2000): 405-433. Osgood continues that the enemy "exists largely in the mindit exists because each believes the other side poses a direct military threat, not because one side had launched a military offensive against the other." Ibid., p. 420.

17 Ibid. Osgood italicizes several key words in his argument about Eisenhower's use of the psychological: belief and appear are among those words.

18 John Lewis Gaddis, Strategies of Containment: A Critical Appraisal of Postwar American National Security Policy (New York, 1982), p. 108. 
and the physical destruction that this new technology implied created a landscape of fear among Americans. Nuclear war itself was becoming "as much an imaginary field as a practical reality." ${ }^{19}$ Americans filled in the gaps of limited information about nuclear weapons with familiar fictional characteristics to understand post-war society as another world war loomed in the near future. ${ }^{20}$

Fear was clearly demonstrated in what Public Opinion Quarterly termed "the Armageddon complex." By 1951, close to half the population of the United States believed a war with the Soviet Union was "inevitable," with many actually wishing it would start. At the core of this "frame of mind . . . seems to lie the drama of a showdown, in which the forces of good finally clash on the field of battle with the forces of evil." Contributing to this view was "the unbearable tension of a prolonged crisis to which the 'lets-get-it-over-with-now' attitude is an understandable response."21 The analysis concluded that as the Cold War continued and the power and size of nuclear arsenals increased, Americans became progressively more anxious about the future. This unease expressed itself in a resignation that war was inevitable and that individuals were powerless to prevent it. This is especially evident in the low numbers of civilian defense

${ }^{19}$ Paul N. Edwards, The Closed World: Computers and the Politics of Discourse in Cold War America (Cambridge 1996), p. 14.

${ }^{20}$ A perfect example of the application of past science fiction to modern day science was an article comparing the literature of Jules Verne to contemporary space flight. Bill Chevalier, "Rocket Scientists Close Gap But Jules Verne Still Holds Lead," Sidney Telegraph, October 14, 1959, sec. 3, page 4. Also see: Peter Costello, Jules Verne: Inventor of Science Fiction, (New York, 1978).

21 Maurice L. Farber, "The Armageddon Complex: Dynamics of Opinion," Public Opinion Quarterly 15 (Summer 1951): 217-224. Italics by author. This attitude was also visible in Civil Defense participation. 
participation, as we will see in Chapter 3.The rapid pace of technology would overtake the means of protection.

Automation only heightened fears and the sense of hopelessness. The imagined power of a push button world already established through science fiction now became science fact in the minds of most of the public. ${ }^{22}$ As one critic observed, "Conflation of present objects with science fiction's iconography of the future creates the sensation of life as science fiction. Such allusive interchanges reveal a twentieth-century mentality in which a broadly conceived notion of science fiction is among our mixed mental reference points." ${ }^{23}$ By the early 1950s it became increasingly easy to connect new defensive measures with push button technology as the public became more aware of computerization.

In 1952 U.S. News and World Report explained to its readers the power of the push button and what it would mean for war. Automation was the wave of the future, the magazine reported. ${ }^{24}$ A year later, Americans found that push button technology was being integrated into their everyday world. In "Push-Button Plant: It's Here," readers were introduced to the "electrical "brains"" that were part of the "plant of tomorrow." Artificial intelligence was going to replace man the article explained Automation,

22 As early as 1947, journalists were reporting of a "push button war" fought with missiles. Joseph and Stewart Alsop, "Are we Ready for a Push-Button War?" The Saturday Evening Post, September 6, 1947, pp. 18-19.

${ }^{23}$ Paul K. Alkon, Science Fiction Before 1900: Imagination Discovers Technology (New York, 2002), p. 9.

24 "Push Buttons Get into War: Meaning of Korea Missiles," U.S. News and World Report, September 26, 1952, p. 32. 
however, would not be foolproof. Readers were warned of inevitable accidents that machines would surely make: "The big problem accompanying 'automation' is that a failure of even the smallest element can shut down an entire production line" causing everything to come to a standstill. ${ }^{25}$ If push button factories could be accidentally shut down, readers were left to wonder, what might happen with push button weapons? Would they fail at the crucial moment, or worse, could they accidentally launch themselves?

As the public was left with anxiety and questions, experts began to promote the virtues of new automated technology. Carl Dreher, a former engineer, wrote Automation: What it Is, How it Works, Who can Use It. ${ }^{26}$ The book simply and enthusiastically described how automation evolved since the first Industrial Revolution and how it wasand would be-incorporated into everyday life. Dreher used metaphors of warfare to explain the importance of the evolution of automation, and devoted a section to "The Automation of War." Here, he explained the marvel of the Intercontinental Ballistic Missile's (ICBM) automated flight and control. Still, even the techno-enthusiast Dreher observed that automation's use in war did not eliminate error: "after burn-out, the missile is in free flight, like a shell, and mistakes or inaccuracies can no longer be corrected." Missiles, however exciting they may be, were not the tell-all answer to national security. As Dreher explained, "technology has destroyed the measure of security that superiority

25 "Push-Button Plant: It's Here," U.S. News and World Report, December 4, 1953, p. 41. During the early 1950, manufacturers were using automation and computerization in their advertisements. One such example is by Borg-Warner, an engineering company. In its ad there is a picture of a human head with a car engine for its brain. Their automatic engine practically thinks on its own: It "Out-Thinks and Out-Acts even a Race Driver!" "B-W Automatic Transmissions, Advertisement, Time, November 1, 1954, p. 53.

${ }^{26}$ Carl Dreher, Automation: What it Is, How it Works, Who can Use It (New York, 1957). 
in arms once afforded. ... [As a result] small wars have become inconclusive and big wars mutually ruinous." 27

The incorporation of computers into the defense arsenal and the increasing reliance on them underscored the public perception of the totality of the next war. During this early development period, the American public — and many government officialsaccording to historian Paul Edwards, felt the next war would be a "global, allencompassing, apocalyptic conflict." 28 One of the reasons for this was there was no precedent for a war fought with nuclear weapons. Americans depended on the limited government information that was released to popular magazines and newspapers as their primary source of information about what future wars would be like to fight and survive. What they did not read they were able to imagine.

In fact, much of the information that was gathered in preparation for surviving thermonuclear war came through professionals in think tanks, such as RAND, founded in 1946. Although non-profit organizations, many think tanks had access to select classified information which they used in their analysis of future wars. They relied on the hypothetical- "simulation techniques based on assumptions, calculations, and hypothetical 'rules of engagement"'- to predict what the next global war would be like and how to prepare the population for survival. ${ }^{29}$ This reliance on the hypothetical—or imaginary-for strategy of future wars became common practice by the late 1950s for

${ }^{27}$ Ibid., pp. 71-72.

${ }^{28}$ Edwards, The Closed World, p. 54. Italics by author.

${ }^{29}$ Ibid., p. 14. 
RAND. Paul Edwards explains that in war games, "The object for each nuclear power was to maintain a winning scenario - a theoretical or simulated win, a psychological and political effect-rather than actually fight such a war. Actual outcomes no longer mattered, since the consequences had become too enormous to be comprehended and too dangerous to be tested. . . . To those that contemplated its strategy, nuclear war could only be understood as a many-leveled game." ${ }^{, 30}$ Therefore, military planners increasingly relied on technology and computers in conjunction with hypothetical variables to conduct war games. Consequently, as think tanks became more influential in military and defense planning, civilian and scientific experts-mathematicians, physicists, technicians, economists, and operational analysts—-began to replace military professionals in national defense strategy. The public understanding of war thus increasingly reflected this "expert" version of war. Think tanks transformed war into a game of imagination, which on some level, everyone could play.

The two elements of accidental war that were most feared-automation and untrained (non-military, or lower ranking) men making key decisions-were now the center of American defense policy. Reliance on operational analysis and computers for war planning and "gaming" marginalized traditional military decision makers in the Pentagon-normally assigned to generals and admirals. ${ }^{31}$ Automation, computers, push button technology, and abstract war games all contributed to the public's sense that the

${ }^{30}$ Ibid., p. 14. Italic by author.

${ }^{31}$ Ibid., p. 70; "Will 'Computers' Run Wars of the Future?" U.S. News and World Report, April 23, 1962, pp. 44-48. 
next war would be both apocalyptic and unstoppable once put in motion. These fears came together in a concrete way with the development of the ICBM.

The intercontinental ballistic missile united the elements of nuclear and thermonuclear weapons with automation and apparent instantaneous delivery methods. As missile development progressed, journalists warned the public that this new technology would be the determining factor of the Cold War - or quite possibly the end of civilization. They focused on the Buck Rogers qualities of this futuristic advancement in defense technology and gave it Wellsian characteristics of technological doom. Newsweek predicted that the missile was the "ultimate weapon in the chamber of horrors that is modern warfare." The country that developed it first would "be in the drivers seat," and the "whole uneasy present balance of world power would be upset." 32 Coupled with science fiction and current politics, this imagery allowed Americans to associate automation together with missiles and war: a Buck Rogers world had arrived. And like the world of the fictional hero, it was one torn between good and evil and fought with terrible new weapons of science.

Predictions of another world war were not new to readers of popular periodicals. Missile imagery was associated with World War III scenarios since the close of the Second World War. ${ }^{33}$ Americans believed that another war was inevitable. The Gallup

32 "Beyond Fancy: Push Button . . And Deliver Atomic Disaster 5,000 Miles Away," Newsweek, February 21, 1955, p. 26; "The Story of the 'Push Buttons' Latest About the New weapons of War," U.S. News and World Report, August 12, 1955, cover.

33 Almost immediately after the close of World War II, another war was predicted and popular magazines helped Americans envision how the Soviet Union would attack the United States. "The 36 Hour War," Life, November 19, 1945, p. 27-35. This article even predicted a missile war. David Lawrence, "The Road to World War III?" U.S. News and 
Poll asked Americans if they thought that Russia was "building itself up" to "rule the world" or to "protect itself." Seventy percent answered that they though Russia was trying to "rule the world." 34 By the early 1950s predictions of a nuclear war had become almost commonplace. ${ }^{35}$ The Gallop Poll had begun asking how soon Americans thought such a war would begin. ${ }^{36}$ Throughout the decade, Americans consistently answered that they thought war not only likely but that it would occur during their lifetime.

By the middle of the 1950s, Americans recognized that the means of waging war were changing. Gone were the days where bombs were dropped by manned aircraft: instead, automated missiles with atomic warheads would be launched by simply pushing a button. Time described this transition well when it informed Americans that because of

World Report, June 7, 1946, pp. 28-29; "92 Atomic-Bomb Targets for Russia in U.S.," U.S. News and World Report, October 7, 1949, pp. 16-17.

${ }^{34}$ George H. Gallup, The Gallup Poll, vol. 2 (New York, 1998), p. 881. By 1953, this number increased to $79 \%$. Ibid., p. 1163.

${ }^{35}$ The list of articles is exhaustive, however, here are a few worth mentioning: Richard Gerstell, "How you Can Survive an A-Bomb Blast," Saturday Evening Post, January 7, 1950, p. 23; David Lawrence, "To Advert World War III," U.S. News and World Report, May 26, 1950, p. 56; "Civilian Defender Clay: No One is Safe, but Some can be Saved," Time, October 2, 1950, cover; "How U.S. Cities can Prepare for Atomic War," Life, December 18, 1950, pp. 77-81; "Russia can be Hit from Two Seas: Heart of Soviet Within 3 Flying Hours of Navy Carriers," U.S. News and World Report, September 26, 1952, p. 13; "If Attacked, U.S. Can drop A-Bomb on Russia in 2 Hours," U.S. News and World Report, October 23, 1952, p. 19, also on cover; "First Blueprint for Atomic War: Planes-Guns-Missiles, All Set to Meet Russians in Europe," U.S. News and World Report, February 25, 1955, p. 24.

${ }^{36}$ In 1949, under the heading "Outlook for War," the Gallop Poll asked if Americans believed another war was likely in 25 or 30 years, with $50 \%$ responding to the positive. In 1950, under the heading "Prospect for War" (the heading that it would keep), the question was slightly reworded, asking if the U.S. would find itself in another war within 5 years, with $41 \%$ answering the affirmative. George H. Gallup, The Gallup Poll, vol. 2 (New York, 1998), pp. 838, 899. 
missiles, they no longer had to worry about an "atomic Pearl Harbor" because it was no longer a feasible possibility. The new ICBM "would end all hope for such aggression." War was changing because "for the first time in human history, all chance of profit will be gone from all-out aggression." New weapons would be hidden underground, Time informed readers, and only "the pressure of a single finger upon a master panel would be enough to rise the fiery spume of pre-aimed ICBMs from launching pads . .."37 This predicted mechanical disconnect of destruction from humans-a reliance on artificial intelligence-alarmed many people and opened the door of discussion to concerns about accidental war. An age of missiles meant a very different kind of warfare and possibly a vastly different kind of future for mankind.

By 1956, popular periodicals were predicting the role of push button technology in the next war. U.S. News and World Report declared that when the guided missile was incorporated into the American arsenal, “"push-button' warfare may have arrived," but manpower, readers were assured, would not be over-ruled by the new weapons system even if the weapons were fully automated. ${ }^{38}$ In contrast, Time found only a limited human role in the ICBM age: "the button need not be pushed by one of General LeMay's

37 "The Missile Standoff: War Without Profit Promises a New Epoch," Time, July 30, 1956, p. 11.

${ }^{38}$ Major Nels A. Parson, Jr., USA. "Guided Missiles in War and Peace," U.S. News and World Report, January 20, 1956, pp. 128-151. By 1958, Newsweek boasted, "the push button comes of age" with a picture of SAC's headquarters sign of a missile and the words "1st Missile Division." The caption under the picture proudly declared: "Signpost at the crossroads of our awesome times." "The Push Button Comes of Age," Newsweek, December 1, 1958, p. 19. 
military experts; it might as easily be pressed by one surviving mechanic." ${ }^{39}$ Therefore, should war come, even those who were not trained professionals could send retaliatory missiles to strike back at the aggressor. Many would soon associate this flexible capability with wonton behavior of unstable or fanatical individuals during times of peace. Instead of calming public uncertainties, it appeared that the proliferation of weapons and advances in weapons systems only multiplied the sense of danger from accidental war.

"In the robot world of guided missiles" potential glitches became evident as futuristic technology gained a foothold in the American military, elevating fears of the incorporation of automation into defense. One such example was a missing rocket that made headlines in March 1957. A Matador refused to self-destruct during a test flight, even though it had its control and self-destruction system "thoroughly and repeatedly checked by Army technicians." This was contrary to past assurances by the Air Force that the "missile can be electronically ordered to blow itself to bits in flight." The Matador flew out of control toward the heavily populated city of Salt Lake City (population: 180,000), and residents were not told until hours after that it was "reportedly heading" in their direction. This article highlighted the consequences of computer malfunction and inadequate civil defense measures. Radio, newspapers, city police, and state troopers had not been informed in time to warn the civilian population; Strategic Air Command (SAC) was too slow to respond; "the city's civil-defense forces were evidently never alerted at

39 "The Missile Standoff," Time, July, 30, 1956, p. 11. It worth mentioning that the Gallup Poll did not begin to ask questions about missiles until after the launching of Sputnik I. 
all. ${ }^{40}$ The article also reminded readers of another accident in December of the previous year when a Snark missile disappeared toward Brazil after it was sent into flight from Cape Canaveral. ${ }^{41}$ As missile development advanced, it was becoming increasingly evident that artificial intelligence was not free from hazard and given the right circumstances, could be just as unpredictable as humans. Questionability of computerization and automation led to a shift in public feeling toward nuclear deterrence.

As Americans adjusted to the new reliance on science and its creation of increasingly destructive weapons to maintain an uneasy peace with the Soviet Union, some began to argue for disarmament. During 1957 the Committee for a Sane Nuclear Policy (SANE) was created. The committee primary aim was to stop nuclear testing, but SANE also aided in the debate to control nuclear weapons technology. After the voluntary suspension of nuclear weapons testing by both the United States and the Soviet Union in August 1958, SANE "turned its attention to intercontinental ballistic missiles and to the threat of nuclear annihilation." This broadened the organization's goal from a general test ban to disarmament. ${ }^{42}$ SANE began publishing full-page high-profile

40 “A Rocket is Missing," Newsweek, March 4, 1957, p. 32.

${ }^{41}$ The Snark program was so full of glitches and had so many crashes off the Florida coast that the waters around Cape Canaveral were said to be "Snark infested." Lonnquest, Kohn C. and David F. Winkler. To Defend and Deter: The Legacy of the United States Cold War Missile Program, vol. I. (Champaign, Il, 1996), p. 283.

${ }^{42}$ Katz, p. 34. Bold advertisements appealed to the average American, helping SANE grow drastically within its first year. "By the summer of 1958 SANE had about 130 chapters representing approximately 25,000 Americans." Ibid., pp. 28-29. Also see: Robert A. Divine, Blowing on the Wind: The Nuclear Test Ban Debate, 1954-1960. (New York, 1978); Lawrence S. Wittner, Rebels Against War: The American Peace Movement, 1933-1983. (Philadelphia, 1984). 
advertisements about the effects of fallout and the dangers of nuclear war. This highly visible advertisement campaign added to the growing unease among Americans about the ability of technology as protection.

Concerns were climaxing in the United States when a Russian article publicized unease about "war-by-accident" toward the end of 1957. Their concerns, however, were not about technological glitches that could lead to war, but unstable humans who controlled the weapons. Citing the large number of "psychotic cases" in U.S. hospitals, the Soviet journal Red Star argued that it "was a well known fact that there are several million psychologically unbalanced persons in the U.S." It warned the British that a "criminal" or "unbalanced person" in the U.S. Air Force "might use the round-the-clock flights of hydrogen-armed American aircraft from British bases to set off nuclear war." Originally believed to be a propaganda ploy, this fear soon gained credibility. ${ }^{43}$

News of technological mishaps continued and Americans became increasingly alarmed. Newsweek assured its readers that new missiles in the American arsenal would "be dependant upon the ministrations of many men." The power and sophistication of new weapons, however, limited the number of men needed to operate them, which created new problems. In comparison with conventional weapons where "short rounds endangered a few men, a misfired atom-tipped missile could endanger thousands. ${ }^{24}$ The added security to weapons safety assured by man's oversight came into question when an atomic bomb was accidentally dropped from a B-47 20,000 feet over the countryside of

\footnotetext{
${ }^{43}$ Carl Dreher. "War by Accident..." The Nation, September 6, 1958, pp. 105-109. 44 “Missilemen," Newsweek, December 23, 1957, pp. 50-51.
} 
South Carolina. Safety mechanisms prevented the atomic component of the bomb from exploding, but the mishap made international news. ${ }^{45}$

Newsweek sensationalized the incident by noting world reaction, which "made a propaganda noise heard round the world" and underscored the probability of human error. In London, a newspaper ran a science-fiction serial about World War III being started by a " "psycho' B-47 bomber pilot who takes nuclear revenge on the Russians." Also in England, a "new propaganda drama showed millions of British TV viewers how a nuclear holocaust starts when a Soviet corporal, rattled by an accidental missile explosion at a Red rocket base, inadvertently pushes the nuclear attack button rather than the accident button." ${ }^{46}$ Newsweek mocked the British for their overreaction to the South Carolina accident but noted the important role of the automation of weapons technology. Quoting Dr. W.H. Pickering, head of the Jet Propulsion Laboratory at the California Institute of Technology (CalTech) and one of the "fathers" of the U.S. Explorer II satellite, Newsweek told readers, "Far more than being slaves to our machines, our very life depends on the accuracy and reliability of a computing machine in a far distant

45 "A-War by Accident?" Newsweek, March 24, 1958, pp. 60-62. What the article did note was "The plutonium component did not explode, but the trigger made of conventional TNT, went off with a blast that injured six persons and damaged six houses and a church in the tiny Mars Bluff community 5 miles east of Florence, S.C." In an editorial criticizing the Air Force, The Nation complained that the Air Force dehumanized this event by using the word "personnel" when referring to citizens, and when the bomb was described as "unarmed" when it destroyed a home and injured an entire family. Editorial, "Citizens or 'Personnel?"” The Nation, March 22, 1958, p. 244.

${ }^{46}$ Ibid. 
country. The failure of a handful of vacuum tubes and transistors could determine the fate of our civilization. ${ }^{, 47}$ Americans were getting mixed signals, indeed.

U.S. News and World Report commented on the world's reaction to the accident in South Carolina by comparing it to the American response-which they called "matterof-fact." The caption under a picture of the explosion read: "Six were injured but no one was killed . . America took it in stride. ${ }^{, 48}$ Perhaps the American reaction was not as intense as the rest of the world because periodicals took the issue so lightly. Like Newsweek, U.S. News and World Report also made jest of the world's reaction to this story of an "atomic accident." As a result of the incident, the British-whom the periodical referred to as the "most jittery"-decided to reevaluate American bomber bases in their country. Of special concern was the Russian reaction. The atomic accident also underscored Russian fears about accidental war. Soviet leaders expressed alarm that "an accidental explosion in the U.S. [could] touch off World War III by being mistaken for an attack from abroad," especially since the U.S. Air Force kept bombers loaded with atomic bombs at all times "as a precaution in case sudden attack . . . in an 'atomic Pearl Harbor." The nonchalance taken by the media about the importance of the incident to national security was underscored by references to at least five or six other occurrences in which atomic bombs were dropped accidentally. ${ }^{49}$

${ }^{47}$ Ibid.

48 "A 'Safe' A-Bomb Drops: Taut World Gets Jitters," U.S. News and World Report, March 21, 1958, p. 55.

${ }^{49}$ Ibid. Incidentally, South Carolina would be the site of another atomic accident a few years later. In January 1961, a jet bomber with two "unarmed" atomic bombs "crashed and burned on a county road" killing at least two of the eight men aboard. One of the 
Fears about automated weapons and accidental war were also reflected in contemporary fiction where the connection between human error, science and technology, and accidental war became a popular topic. It was during the late 1950s that apocalyptic fiction began its début, starting with Nevil Shute's 1957 classic On the Beach. The story takes place in the future of 1963 Melbourne, Australia. The deliberate release of radioactive cobalt wiped out civilization in the northern hemisphere, and the deadly radioactivity slowly encompassed the southern hemisphere until only those in Australia are left to face the inevitable end of human life on earth. ${ }^{50}$ The book was well received and most of its reviews were favorable. Atlantic commented "Only a very humane writer could have told a story as desolate as this and made it seem at once so close and implacable." The New Republic observed, "It falls, actually, into the category of evangelical effort ... to save the world from its own folly." ${ }^{, 52}$ Widely read and discussed, this book would be made into a movie by the end of the decade. In movie form, On the Beach had a wider audience and further flamed the discourse of nuclear weapons and their consequences in war.

nuclear bombs was found 12 miles from the crash scene. "The wreckage," it was reported, "fell within 200 yards of homes" and spaned a radius of 1.5 miles. "Jet Bomber With Nuclear Arms Crashes," Wyoming State Tribune, January 24, 1961, p. 1.

${ }^{50}$ Shute, Nevil. On the Beach (New York, 1957). SANE also distributed this book in an effort to gain popular support for banning nuclear testing. Divine, p. 268.

${ }^{51}$ The Book Review Digest. March 1957 to February 1958 Inclusive (New York, 1958). p. 687.

${ }^{52}$ Robert H. Estabrook, “After Armageddon,” New Republic, August 12, 1957, p. 20. 
Shortly after the publication of On the Beach, former Royal Air Force Officer Peter Bryan George wrote Red Alert. ${ }^{53}$ First published in Great Britain as Two Hours To Doom, it would become the basis for Stanley Kubrick's satirical film Dr. Strangelove: How to Stop Worrying and Love the Bomb. Unlike the movie, the book was not a comedy. It is a serious drama about a fanatical general who, during a SAC alert, gives the code for the $843^{\text {rd }}$ SAC bomber wing to go past the fail-safe mark and attack the Soviet Union. All but one of the bombers is recalled and an atomic bomb is dropped. The bomb fails to reach its target, and the final B-52K is shot down, averting accidental war.

Both of these books deal with war before the arrival of the missile and true "push button" technology, but they still highlight contemporary concerns of the consequences of accidental war. Automation and the technical side of modern warfare appear in Level 7, written the following year by Mordecai Roshwald. ${ }^{54}$ The novel takes place below the earth's surface in survival shelters of different levels - the depth of the shelter co-insides with the importance of the groups of individuals it is meant to protect. Level 7 houses those who fight the war by controlling the missile "push-buttons" and those who are chosen to regenerate the population when the earth's surface becomes habitable again. A group of four men are responsible for conducting war by pushing buttons on commandmaking total war almost completely dependent on automated technology. Using a set of keys similar to a typewriter, the bombs are delivered in order of severity: "Each of the

53 Peter Bryant, Red Alert, (New York, 1958). Peter Bryan George was "deeply committed to nuclear disarmament" and later wrote another novel "to denounce the use of nuclear weapons," Commander-1. http://en.wikipedia.org/wiki/Peter_George

${ }^{54}$ Mordecai Roshwald, Level 7, (New York, 1959). This book is dedicated to Dwight (Eisenhower) and Nikita (Khrushchev). 
twelve buttons would release several thousands of otherwise electronically controlled and guided missiles, every one of them aimed at a predetermined target. They would hit the enemy within anything from fifteen minutes to an hour from when the button was pushed." ${ }^{, 55}$ To avoid an accidental war or the possibility of someone starting a war "who took leave of his senses," the buttons had to be pressed simultaneously by two trained technicians at separate instruments-not unlike the launching of ICBMs from silos. In Level 7 automation and missiles are to blame for the demise of humanity. An Air Force Commander linked automation with apocalypse at the close of the book:

...The moment those guided missiles appeared-especially those ground-to-ground intercontinental rockets-civilization was doomed. No more glory for men, no more brave combats in the air, no more bombing of cities and installations by men who knew what they were about. But dehumanized war, automatic war, and its inevitable result: the end of civilization. ${ }^{56}$

Another popular dooms-day scenario book Fail-Safe written by Eugene Burdick and Harvey Wheeler appeared in 1962 and ran as a series of extracts in The Saturday Evening Post. ${ }^{57}$ As in On the Beach and Red Alert, the accident that occurs in Fail-Safe is not started by a misfired missile, accidental explosion, or escalated limited war. It is not set in a distant Buck Rogers future. Rather, the scene is contemporary America and the principal actors are the President and SAC. The accident occurs through human error

${ }^{55}$ Ibid., p. 20.

${ }^{56}$ Ibid., p. 129.

${ }^{57}$ Eugene Burdick and Harvey Wheeler, Fail-Safe (New York, 1962); The Saturday Evening Post, October 13-27, 1962. Peter George (Bryant was his pseudonym) sued the authors of Fail-Safe for its close similarities to Red Alert and won an out-of-court settlement. The books are very similar; it is their subsequent movies that are different in character. 
made possible by undetected flaws in complex, technologically mediated procedures. Fail-safe was suppose to be "a fool-proof procedure" to preclude "accidental attack because the president alone can give the final order, relayed to the bombers through a code system that insures the authenticity of his commands." ${ }^{\text {58 }}$ Once activated, however, the fail-safe procedures then block any command or human appeal to avert an impending disaster.

Because of its realistic portrayal of the accidental release of nuclear weapons, Fail-Safe caused quite a sensation. It was a 1962 best seller and perhaps more than any other work it highlighted the fear that a war could start by mistake. ${ }^{59}$ In fact, Fail-Safe took aim at the very precautions put into place to prevent accidental war. The accident occurs through a breakdown of the checkpoints designed to prevent technology from running wild. Although machines and advanced technology are accomplices, the real villain of this novel is human frailty: false confidence in the reliance on precautionary "fail-safe" methods of relaying messages of attack triggers the destruction of both New York City and Moscow.

Both Fail-Safe and Red Alert also explored the possibility of temporary insanity of military leaders and war-hardened vets who refused to believe the possibility of accidental war. These men completely believed in technology and the righteousness of their cause. They also were indoctrinated with the belief that the enemy would do anything necessary for victory and often believed in the necessity of preemption. They

${ }^{58}$ David Dempsey, "Operation Disaster," New York Times Book Review, October 21, 1962 , p. 5.

59 "New Fail-Safe," Time, December 28, 1962, p. 16. 
looked over their shoulders and read between the lines-expecting infiltration. The authors did not limit frantic behavior to the enemy, but demonstrated military leaders from both sides could be unreliable and irrational in times of crises. ${ }^{60}$ In fact, another maybe-not-so-obvious example of insanity was that of the President of the United States and the Soviet Premier. In both books, they calmly evaluated the situation and determined that an accidental bombing of a Russian city would be justified if an American city were sacrificed in return. The "rational" way to prevent war in the nuclear era now became the killing of one's own people.

Seven Days in May, published in 1962, also focused on the human role in global catastrophes. ${ }^{61}$ The plot involves a chasm within military leadership that attempts a military coup against the President of the United States-while his approval polls are there lowest. Fletcher Knebel and Charles W. Bailey concentrated on the importance of intelligence secrecy and the value of public opinion to demonstrate that man is the wild card in a dangerous world. One critic noted that the authors showed how Americans "have become habituated [to government secrecy] since Pearl Harbor not only bars the citizen from information that may poignantly concern him, but even atrophies his

${ }^{60}$ Climbing to the top of the Best Sellers list almost immediately, Fail-Safe was not without its critics. Most notable were those in the highest echelons of official circles. "The book was attacked by the magazine Time (after earlier laudatory comment), by a retired general in Newsweek, and by a former SAC information officer in America. The burden of complain is as follows: "the particular accident which the authors, Burdick and Wheeler, invented could not happen, therefore the idea of accident is fallacious; further the book is immoral, not to say un-American, since it implies that the custodians of our atom bombs are not infallible and distracts the public from its fixed gaze on the beastliness of the enemy." "Speak Up, Mr. Critic," Nation, February 9, 1963, pp. 110111.

${ }^{61}$ Fletcher Knebel and Charles W. Bailey II, Seven Days in May (New York 1962). 
curiosity as to what these forbidden documents and areas may contain." 62 This book was released when concerns about accidental war shifted from begin caused by reliance on automation to the possibility of unstable human interaction with automation. As we have seen in Chapter 1, the lack of government transparency was a concern and often backfired in the Eisenhower administration. Seven Days in May chronicled a coup able to take place because the abundant use of secrecy also meant little oversight and limited overlap of powers. These were valid concerns during this time. ${ }^{63}$

The moral issues addressed in apocalyptic fiction had long been expressed in the nation's scientific community. But the missile raised them to a new level of concern. In the June 1958 issue of The Bulletin of Atomic Scientists, a collection of essays was printed addressing the relationship of technology, accidental war, and national defense. The biophysicist Eugene Rabinowitch noted many in government leadership positions did

${ }^{62}$ Robert Hatch, "Making Tomorrow Convincing," Nation, November 3, 1962, pp. 291293. Lapp also noted the role that secrecy played in the American foreign policy in Kill and Overkill: "The policy of supersecracy (sic) here runs directly counter to the professed reason for accumulating [a nuclear] stockpile. If the purpose is to prevent war by threatening any aggressor with overwhelming retaliation, then the rational course would seem to be to advertise, rather than conceal, the size of the striking power!" Ralph E. Lapp, Kill and Overkill, (New York, 1962), p. 40.

${ }^{63}$ Seven Days in May, might have been written as a result of the voluntary nuclear test ban that began in 1958, as it contains uncertainty about Soviet intentions with nuclear weapons and criticizes the gullibility of the United States. During this time, there was much speculation about the "real" activities and intentions of the Russians, and many believed that they were secretly testing nuclear explosives "behind the back" of the United States - making the United States not only look naive but also preventing it from staying "ahead" in the arms race. As Thomas J. Dodd, the Senator of Connecticut, put it, "No single subject in our time has been so befuddled by propaganda, wishful thinking and international hysteria as the banning of nuclear tests." Thomas J. Dodd, "Why We Must Repeal the Ban on Nuclear Testing," The Reader's Digest (September 1960): 8389. 
not take the dangers of accidental war seriously and still depended on traditional bombers. He hypothesized that the Soviet Union was better informed about what was going on in the United States then the other way around. His reasoning was based on information that American leadership responded to every suspicious object that appeared on its Distant Early Warning (DEW) radar screens with "H-bomb laden SAC planes" headed in the direction of the Soviet border while the Soviets did nothing in return. "It was this asymmetry of the situation," Rabinowitch told readers, "which reduces the danger of fatal accident." ${ }^{64}$ But, he warned, even when the future solid propellant missiles of the Minuteman family were completed, safety would still not be assured. "[H]ours of decision time are telescoped into minutes and seconds" when the missile becomes the primary weapon of the American arsenal. More importantly, he continued, "There will always be a risk of a missile [self-] destroying device not functioning properly, and the missile continuing on its fatal course," reminding readers of the runaway Matador of the year before. Rabinowitch warned that the public must be aware of the "increasing possibility that an all destructive nuclear war can break out without anyone deciding to start it." ${ }^{, 65}$

${ }^{64}$ Oddly enough, it has only been recently disclosed that Soviet launch-on-warning capability since its development, had serious "gaps" and "was not designed to detect sealaunched missiles." As a result, the "Soviet military learned to regard the alarms it generated with suspicion." Pavel Podvig, "If It's Broke, Don't Fix It: The Russian Early Warning System is in Tatters, Which is Precisely Why it Works," The Bulletin of Atomic Scientists 61 (July/ August 2005): 21-22.

${ }^{65}$ Eugene Rabinowitch, "Accidental War, Missiles, and World Community," Bulletin of Atomic Scientists 14 (June 1958): 202-204. 
Those who worked for and with the United States government also supported concern about accidental war. Richard Leghorn, a Colonel in the Air Force Reserve and pioneer of intelligence gathering, argued that viewing disarmament issues in the context of accidental war made their possibility more realistic and also made their solutions appear more practical and imperative. To Leghorn, the power to recall bombers was not the most important threat: it was what "may happen in the true push-button period if both sides maintain [their] capacity for massive retaliation." With bombers minimized, one of the primary elements of danger was the "enhancement in rocketry." ${ }^{\text {"66 }}$ Carl Dreher added to this by listing the possible causes of accidental war as "technological mishaps and inadequacies and psychological and personnel hazards." ${ }^{.67}$ Citing past catastrophic accidents with missiles-without warheads-that killed several service men, Dreher concluded that the increased pace of technology would outpace developments in safety precautions adding, "human elements complicate the nuclear situation." 68

${ }^{66}$ Richard S. Leghorn. "The Problem of Accidental War," The Bulletin of Atomic Scientists 14 (June 1958): 205-209. Leghorn was a former AAF pilot during WWII, and he advocated the need to collect intelligence information during times of peace to prevent surprise attack and "pressed for the development of a new, high-flying spy plane," which eventually became the U2. Philip Taubman, Secret Empire: Eisenhower, the CIA and the Hidden Story of America's Space Espionage (New York, 2003). Leghorn wrote about his views of a "counter-force strategy" to win a war with the Soviet Union as early as 1955. See: Richard S. Leghorn, "No Need to Bomb Cities to Win War," U.S. News and World Report, January 28, 1955, pp. 78-94.

${ }^{67}$ Carl Dreher. "War by Accident ..."; The threat of small wars was real-especially to military planners because of the reallocation of troops through the New Look doctrine. The New Look limited conventional ground troops and increased air power and atomic weapons. This argument was made as early as 1954 . "Congress Takes a Look at "New Look' in Defense," U.S. News and World Report, February 26, 1954, pp. 48-51.

${ }^{68}$ Ibid. 
As technology removed the human element from war, it also heightened human frailties. The time was approaching when both the Soviet Union and the United States would have their nuclear ICBMs "planted in strategic locations" with each installation "subject to the control of individual officers," a Bulletin reader predicted. This would result in "control of the world's fate" shifting from "the hands of governments" to "the hands of individuals, subject to all the frailties of human beings." It would only take "one error, one nervous breakdown with its resultant lapse of responsibility, one 'false alarm,' [to] bring about the launching of the first missile, which of course, will be followed by Armageddon." 69 George Rathjens, Jr., of the Institute for Defense Analysis and the Weapons Systems Evaluation Group of the Office of the Secretary of Defense concurred with this analysis. In addition, he argued that as the technological capabilities of weapons advanced, strategic concepts would be outmoded and as a consequence, some of these ideas "may be as obsolete as the weapons that existed when these concepts were formulated."70 Thus, defense policy was not keeping pace with technological progress, and it would be this that would eventually jeopardize peace through accidental war.

Several books were written by members of the RAND Corporation that addressed the issues of modern defense strategy in an age of thermonuclear weapons. Bernard Brodie's Strategy in the Missile Age examined the history of air strategy and current military problems. He concluded that a new direction needed to be taken in light of

${ }^{69}$ Allan L. Fletcher. “...To Relax the Tension,” Letters to the Editor, Bulletin of Atomic Scientists 14 (May 1958): 200.

${ }^{70}$ George W. Rathjens, Jr. "Deterrence and Defense," The Bulletin of Atomic Scientists 14 (June 1958): 225-228. 
advancing weapons systems. ${ }^{71}$ Brodie also examined accidental war and stressed that the public must "take seriously the fact that the danger of total war is real and finite, and that provisions must be made for the saving of life on a vast scale." ${ }^{, 2}$ Brodie's expertise in atomic weapons systems was well known, respected, and influential. Henry Kissinger wrote that Brodie "was among the first to recognize the strategic significance of nuclear weapons," and that he foresaw "the paradox that every increase in our destructive ability had a tendency to paralyze the will to resort to it."73

Another member of RAND produced two still more important volumes. On Thermonuclear War and Thinking About the Unthinkable by Herman Khan examined the little talked about effects of hydrogen bombs on the landscape and the human race. Kahn candidly discussed what many would not: the need to prepare for such a catastrophe. ${ }^{74}$ Written in lecture form, On Thermonuclear War was a very controversial book- reviews both applauded and criticized Kahn. Just as controversial, Thinking About the Unthinkable discussed "deterrence, the arms race, disarmament, the possibility of accidental war, war by miscalculation, catalytic war" and the need for civil defense. To one reviewer, his arguments were "the most convincing argument for an enlightened civil

${ }^{71}$ Bernard Brodie. Strategy in the Missile Age, (Princeton, 1959).

72 C.W. Sherwin, "Military Strategy in the Atomic Age," The Bulletin of Atomic Scientists 16 (April 1960): 140. Italics by the author.

${ }^{73}$ Henry A. Kissinger, "Yesterday's Minds and Tomorrow's Weapons," New York Times Book Review, September 27, 1959, p. 3.

${ }^{74}$ Herman Kahn, On Thermonuclear War, (Princeton, 1960). Herman Kahn, Thinking About the Unthinkable, (New York, 1962). 
shelter program" than anything thus far. ${ }^{75}$ Khan's books were widely read because they dealt with highly technical matters in ways that were both interesting and understandable. As one reviewer commented, Khan's work "could hardly fail to frighten American readers,"-and frighten it did. ${ }^{76}$ Kahn's frank discussion of the effects of a thermonuclear war and his critique of the strategies of mutual annihilation and automatic-deterrence alarmed the public and added to their desire to prevent war-especially one caused accidentally. ${ }^{77}$

Khan made readers observe their landscape differently by viewing the aftermath of catastrophic war with scorched earth and millions of dead or dying. But he also made Americans visualize what could not be seen: concealed missiles beneath the earth, missiles projected through the atmosphere, and people hidden in shelters for protection from unseen fallout. Fear permeates his analysis. The United States had been preparing for World War III since 1951, but the information that Americans received about nuclear

${ }^{75}$ The Book Review Digest, March 1962 to February 1963 Inclusive, (New York, 1963), p. 631 .

${ }^{76}$ George G. Kirstein, "The Logic of No Return,” The Nation, January 4, 1961, p. 34.

${ }^{77}$ Another reason for the Kahn controversy was his detached attitude while discussing thermonuclear annihilation. A perfect example of this is in his reaction piece in U.S. News and World Report where he commented that if only five atomic bombs were dropped in this country, the U.S. government would investigate - rather than retaliating by "press[ing] a button." Kahn stated: "If only five bombs drop in a country, this could not be a deliberate, successful Soviet attack. There are not enough bombs involved. It must be something else. So you've got to find out what it is. You don't want it to happen again." Kahn did not detail the suffering, death, and devastation that only five bombs would do to the country. He merely stated that it is not enough to constitute a real attack: Five bombs can be an accident. This in itself was an accident worth pondering. Herman Kahn, "A 'Doomsday Machine'-Last Word in the Arms Race?" U.S. News and World Report, May 1, 1961, pp. 64-65. Italics mine. 
and thermonuclear weapons had been limited and sanitized. ${ }^{78}$ Kahn's work was the most graphic to date, because as he argued, "To many this is an unthinkable subject; any attempt to think about it is [considered] either evil or insane."

Kahn's work did not console readers but rather heightened already established fears. This is especially evident in an article printed in The Saturday Evening Post. Kahn explained in "We're Too Scared to Think" that the "most dangerous and destructive but quite conceivable way in which world war could be brought about in the immediate future-perhaps tomorrow-would be for some buttons to be pushed by accident, thereby setting off nuclear weapons on the United States or Russia." He gave no assurance against accidental war, and he pointed out that with so little accomplished with civil defense-both by the American public and by the government-there would be little likelihood of survival when war did come. To protect oneself, Kahn recommended going underground. Adequate shelters, Kahn argued, "might make the difference in saving $50,000,000$ American lives. . . . The world is too accident prone, too disaster-prone, for us to play by ear." ${ }^{80}$ Questions about the power of new weapons remained unanswered and missile development accelerated increasing concerns about accidental war to both the American public and professionals alike.

${ }^{78}$ In response to the information that the AEC was giving to-and with holding fromthe public about "blast, fire, and fallout," Ralph Lapp argued, "The AEC has consistently minimized the effects [of thermonuclear weapons], especially from fallout." Kill and Overkill, p. 49. This was also a primary argument of SANE.

${ }^{79}$ Herman Kahn, "Speaking Out The Voice of Dissent: We're Too Scared to Think," The Saturday Evening Post, September 16, 1961, p. 12.

${ }^{80}$ Herman Kahn, "Speaking Out The Voice of Dissent: We're Too Scared to Think," p. 14. 
Nuclear physicist Ralph E. Lapp confronted the topic of weapons stockpiles, reliance on automation, and mutual annihilation in his book Kill and Overkill. He began his book with an accidental war scenario confronting the President of the United States reminiscent of the novel Fail-Safe. An alarm from North American Defense Command (NORAD) warning of Condition Red reads "BMEWS [ballistic missile early warning system] HAS PICKED UP SEVERAL HUNDRED OBJECTS OVER THE NORTH POLE-COMPUTERS PREDICT IMPACT ON USA IN TWELVE MINUTES-ICBM IDETIFICATION PROBABLE-SAC ALERTED—CD SIGNAL HOLDING." Identifying the "several hundred objects" as meteors and not missiles, Lapp used this scenario to alert the public of the "narrow margin between mankind and disaster." ${ }^{.81}$ The public was "sleeping," Lapp argued, because it had only a "hazy conception of the grotesque proportions of the size of the bomb stockpile." Like Herman Kahn, Lapp tried to educate the public with information that was traditionally not discussed. He identified the paradox of nuclear weapons as the public thinking only a "madman would pull the trigger' while placing their hopes in security through larger nuclear arsenals. ${ }^{82}$ The title of the book encapsulated his argument: kill and overkill refers to the strategy of annihilation through the over abundance of weapons of mass destruction. ${ }^{83}$

\footnotetext{
${ }^{81}$ Ralph E. Lapp, Kill and Overkill, pp. 4-5.

${ }^{82}$ Ibid., p. 7.

83 "The nation's arsenal of weapons, in short, has grown to a monstrous stockpile which could not only kill, but overkill, any possible enemy or group of enemies. In the name of defense the military has pursued a policy which an outside observer might well regard as the strategy of annihilation." Ibid., p. 10.
} 
Anxieties about accidental war also manifested itself politically. About the same time that Khan's On Thermonuclear War was released, Representative Charles O. Porter (D-Oregon), took up the cause of accidental war in the House of Representatives. Like much of the public, Porter believed that World War III was imminent. And like a growing portion of Americans, he felt war would be the result "of an unauthorized or accidental nuclear explosion." He argued that there were three reasons for accidental war: "First, thousands of nuclear weapons, many of unthinkable power, exist today. Second, almost all of them are ready for instant detonation. Third, their custodians are human beings." Therefore, rather than believing that human interaction with weapons would act as a safeguard, Porter believed that humans would be the cause of accidental war. Porter visited SAC Headquarters in Nebraska and was briefed on the possibility of such a possibility. He reported to Congress that at SAC he learned that if there were an atomic explosion that could not be categorized as accidental, unauthorized, or aggression, SAC would continue to go on its highest alert. This alert would be matched by the Soviets. He offered a vivid picture of the consequences:

Our planes are making for the Soviet Union; theirs are headed toward us. Our missiles are made ready for immediate dispatch; so are theirs. I remind you that we cannot look at the gaping hole and its lethal radioactivity to tell us who caused the explosion and for what reason. There is no wreckage to examine and there are no witnesses to interrogate.

But less than twenty minutes after the explosion, if it happens in the United States, the Soviet Union's condition of top alert will be reported to the White House by our intelligence officers. The tough question is, how can we tell whether the intensive preparations are defensive or offensive?

The answer is that we cannot make any such determination because the preparations for defense and offense are identical.

Our planes can turn back when they reach a certain point, called the fail-safe line, but on what bases do we dare allow them to return when we know the Soviet planes are headed toward us? Is this the time when the 
President calls up Khrushchev and says, "Tell me the truth now, was that explosion the beginning of an attack on us? Or if it wasn't, are you planning to use our defensive preparation as an excuse for an attack on us? It seems hardly worth the while to make the call, yet how do we extricate ourselves in such a crisis ? $^{84}$

Such crises were more than probable, Porter concluded, but accidents did not mean the end of civilization or World War III. Like nuclear scientists, he proposed disarmament as the means to avoid catastrophe.

When Porter presented his article written for The Nation (along with letters from readers) to the House of Representative, he argued that accidental war was "far more probable than war by intention." 85 The collection of letters that accompanied Porter's argument demonstrated this fear. One concerned reader who wrote in the name of the Nelson-Nora Methodist Church worried about the reliance on automation with few individuals controlling weapons. "Electronic brains" at SAC headquarters "start the machinery moving so that [ICBMs] can be in the air in about 10 minutes and on target within 30 minutes." If "someone who knows the code" goes insane, it might be possible for him to blow up the world. He asked, "Do you have any information on this? If this is true, every American citizen should know it." ${ }^{, 86}$ Another concerned American writing in

${ }^{84}$ Charles O. Porter, "Accident or Aggression?" The Nation, March 5, 1960, pp. 202-205. Italics mine. This scenario is very similar to both Red Alert and Fail-Safe.

${ }^{85}$ U.S. Congress. House. Representative Porter of Oregon speaking about "War by Miscalculation." Proceedings and Debates. $86^{\text {th }}$ Congress, $2^{\text {nd }}$ sess., Congressional Record (March 31, 1960), vol. 106, pt. 6:7083-7088.

${ }^{86}$ U.S. Congress. House. Letter written by Lincoln B. Justice of The Nelson-Nora Methodist Churches in response to Rep. Porter's article "War by Miscalculation." Proceedings and Debates, $86^{\text {th }}$ Congress, $2^{\text {nd }}$ sess., Congressional Record (March 8, 1960), vol. 106, pt. 6:7087. In fact, the instability of a man associated with the missile project was front-page news a few months later. A missile base worker in Fort Collins, 
the name of the First Unitarian Church of Los Angeles, informed Porter of an accident that already happened in Santa Barbara, California, where a Conelrad tape was played saying "'this is not a test, this is it, seek bomb shelter,' etc." He continued that the station "has been apologizing all morning for this mistake. ${ }^{, 87}$ Yet another reader complained that because the United States government did not keep "nuclear know-how" a secret from the Soviet Union, contemplating the future was complicated and "makes a nightmare of living." 88

Concerned citizens related the relevance of this subject to the release of the movie On the Beach. In Colorado, a professor wrote that there was much concern of accidental war in his home state, and "On the Beach dealing with the threat of nuclear destruction has drawn large audiences, and people are eager to find ways to eliminate the threat of radiation." 89 A doctor and his wife wrote from Madison that because On the Beach was

Colorado shot and killed his wife and was involved in a police shoot out. "Missile Base Worker held in Shooting of His Wife," Wyoming State Tribune, May 23, 1960, p. 1.

${ }^{87}$ U.S. Congress. House. Letter written by Stephen H. Fritchman of the First Unitarian Church in response to Rep. Porter's article "War by Miscalculation." Proceedings and Debates, $86^{\text {th }}$ Congress, $2^{\text {nd }}$ sess., Congressional Record (March 8, 1960), vol. 106, pt. 6:7088.

${ }^{88}$ U.S. Congress. House. Letter written by Helen J. Tefft in response to Rep. Porter's article "War by Miscalculation." Proceedings and Debates, $86^{\text {th }}$ Congress, $2^{\text {nd }}$ sess., Congressional Record (March 8, 1960), vol. 106, pt. 6:7088. Conelrad (control of electromagnetic radiation) goes into effect in an alert. Radio stations go off the air, switching to channels 640 or 1240 to broadcast information and instructions. But there is at least a twenty-minute delay for the change over to take place. Gene Marine, "Our Stupid Civil Defense," Nation, February 9, 1957, pp. 111-115.

${ }^{89}$ U.S. Congress. House. Letter written by Dr. Paul A. Bates of Colorado State University in response to Rep. Porter's article "War by Miscalculation." Proceedings and Debates, $86^{\text {th }}$ Congress, $2^{\text {nd }}$ sess., Congressional Record (March 8, 1960), vol. 106, pt. 6:7088. 
soon to be released in their city, they thought it was a "telling moment to call attention to what most of us believe to be but a weird nightmare, not possible." 90 On the Beach visually interpreted mental anxieties about nuclear annihilation and helped bring these concerns to the fore as a mass-released motion picture.

The United States Senate heard conclusions on the dangers of accidental war a few months after Porter's presentation. A study by a group of scholars from Ohio State University over a five-month period argued that public concerns about the possibility of accidental war were justified. Very little had been done to adopt policies to prevent accidental war. The scholars "painstakingly" evaluated the world situation, technological advances in defense, and consequences of accidental war. The study revealed that accidents with nuclear weapons were prevalent enough for the Air Force to have a code name them: "Broken-Arrow," but it concluded "accidental nuclear explosions are among the least likely direct cause of accidental war." $" 91$ The real culprit was man's limited

${ }^{90}$ U.S. Congress. House. Letter written by Dr. and Mrs. Karl Paul Link in response to Rep. Porter's article "War by Miscalculation." Proceedings and Debates, $86^{\text {th }}$ Congress, $2^{\text {nd }}$ sess., Congressional Record (March 7, 1960), vol. 106, pt. 6:7086. Only a few months later, Steward Alsop criticized college students for believing the effects of fallout portrayed in On the Beach. In a lecturing tour, many students were using On the Beach as a reference for what they assumed to be a "technically accurate presentation of the radioactive side effects of nuclear warfare." Although the threats of fallout are real, they are not without prevention, he argued. What is worth emphasizing, however, is that Alsop felt that the fears highlighted in this novel were real because of repeated reference to $O n$ the Beach: audiences of both the novel and film were concerned about the harm of nuclear weapons. Stewart Alsop, "Let's Stop Talking Nonsense About Fallout," The Saturday Evening Post, July 23, 1960, p. 10.

91 “Over Dozen Bomber Mishaps Involving N-Arms Reported," Wyoming State Tribune, November 23, 1962, p. 3. 
interaction with these new weapons. Concerns shifted from too much reliance on automation to questions about the stability of the men controlling these weapons.

The human element compounded fears of accidental war. Twelve psychologists with military experience were asked their opinions about man's interaction with increasingly destructive weapons. Ten of the twelve believed "that the problem of human aberrations in relation to modern weapons systems was serious enough to warrant extensive consideration. There was general agreement that no existing test can reliably screen out individuals susceptible to mental breakdowns." In addition, there was the "predispositions of national leaders for taking or avoiding action.,"92 Congress heard a collection of arguments about accidental war and neither they nor the Executive were willing to abandon nuclear deterrence as national policy. Disarmament had been discussed since the beginning of the atomic age, but neither the United States nor the Soviet Union considered the matter seriously. Neither side was willing to negotiate the terms set by the other.

Unlike the Eisenhower administration before it, the Kennedy administration was persuaded by the possibility of accidental war and discussed it in the first weeks of coming to the White House. The National Intelligence Estimate presented to the president on January 17, 1961, addressed the dangers of nuclear weapons, their development in other countries, and secrecy within the government and between governments. Two accidental war possibilities were recognized: heightened tensions leading to a preemptive

92 Senate, "A Study of Policies to Reduce the Danger of Accidental War in the 1960s," Proceedings and Debates, $86^{\text {th }}$ Congress, $2^{\text {nd }}$ sess., Congressional Record (August 12, 1960), vol. 106, pt. 12:16266-16271. 
strike and sheer accident— "through communication failures and anomalies, irrational action by local crews or commanders, or errors in judgment." ${ }^{\text {93 }}$ Secretary of Defense Robert S. McNamara narrowed the end result of accidents, and declared, "Decisions, not incidents, make war." He suggested reducing the "dependency of our retaliatory power on quick decisions." This would demonstrate to both the enemy and allies of the United States that Americans "do not need to act hastily or preemptively in order to be able to retaliate. We must not be forced in a crisis to take 'crash' actions for the protection of our forces that might be interpreted as evidence of impending strike." ${ }^{, 94}$ It appeared as thought the United States government was seriously addressing the risks of accidental war.

Accidents-whether a malfunction or human error-were thought to be inevitable because of advances in missile technology, the resulting shortening of reaction times, and growing reliance on computer "push button" automation. Mistakes continued to happen. "On a delightfully summery afternoon last week," Newsweek reported on June 20, 1960, "the Teletype machine at the New Jersey Police station in Princeton clicked out: 'Atomic warhead explosion ... nobody injured ... Bomarc site, $46^{\text {th }}$ Air Defense Missile Squadron.' No one knows exactly what Air Force Sgt. Clarence Baldwin said in his excited phone call to Fort Dix state police as smoke and flame rose from an atom-armed

${ }^{93}$ National Intelligence Estimate, Washington, January 17, 1961. FRUS, 1961-1963, 8:310. The example of heightened tension was as follows: "Whenever international disputes arise there is a natural tendency for the parties concerned to place their forces on alert status and to progressively strengthen the alert by various forms of deployment." This could lead to other parties committing to an extent to which they could not back down, and "thus become involved in war." The state of alert may become so far advanced that "fearing a surprise attack, one would take pre-emptive action against the other."

94 Letter from Secretary Defense McNamara to President Kennedy, Attachment, Washington, February 20, 1961, FRUS, 1961-1963, 8:35-48. 
Bomarc missile's shed a few dozen yards behind him. But one thing was certain: The panic button had been pushed." ${ }^{\text {95 }}$ In fact, the reliance on weapons of mass destruction as a means of deterrence was becoming increasingly questionable to Americans-both as a national defense policy and as a high risk factor.

The possibility that accidents rather than decisions could lead to war was reinforced by the U-2 incident of May 5, 1960, when an American spy plane was shot down over Russian territory and its pilot Francis Gary Powers was taken prisoner. Americans overwhelmingly felt the Eisenhower administration handed the incident well, but fifty percent of those polled sensed another war would happen "sooner or later." 96 It was up to the leaders of major nuclear powers to prevent crises from getting out of hand, an article argued in the Bulletin of Atomic Scientists. If one side placed its forces on alert when a small accident occurred, the other side was likely to do the same, thus putting great strain on other countries. "At this point in the development of the situation, a kind of deadly game is almost certainly going on." Given the tense situation, it continued, "a pre-emptive attack becomes more likely." The most important element in such an eventuality is rational decision making. Rationality is "essential for the concept of 'stabilized deterrence' to be effective. ${ }^{, 97}$ Not all humans reacted rationally, but faith in human rationality continued, despite books such as Fail-Safe that questioned the

95 "The Panic Button,” Newsweek, June 20, 1960, p. 72: "Over Dozen Bomber Mishaps Involving N-Arms Reported."

${ }^{96}$ George H. Gallup, The Gallup Poll, vol. 3 (New York, 1998), pp. 1672-1673.

97 John B. Phelps, “The Danger of Accidental War," The Bulletin of Atomic Scientists 17 (April 1961): 146-148. 
conventional tones of rationality were enough given the mixture of power, technology and fear in play in the nuclear age.

Rationality came to the fore when in late 1962 , newly disclosed information was released by the Department of Defense about aborted accidents by mentally unstable individuals working with nuclear weapons. This revealed that faith in human checkpoints was not a safeguard against accidental war. Newsweek told its readers that although stories of "emotionally unstable military men going berserk" may sound like something from a science fiction novel, they have actually already happened. It was reported that in 1958, an Air Force sergeant "assigned to maintenance work on nuclear weapons" threatened to fire a pistol at a weapon he was standing next to in order to commit suicide. Although the nuclear material would not have detonated, the TNT within the bomb would have exploded, injuring and possibly killing those nearby. Another incident that was reported happened at Vandenberg Air Force Base, California. An airman forgot "to attach a ground wire to an electrical circuit," which resulted in a Titan missile-without its nuclear warhead-to explode and burn. It turned out that this man "was suffering from a severe emotional stain." The third occurrence concerned an air policeman that wanted to be transferred because "he was being troubled by a strong urge to fire his pistol at one of the Atlases poised on the launching pads." These and other episodes like them resulted in regulation 35-9, entitled the Human Reliability Program.

Under this regulation, Newsweek assured its readers, "all men who work with nuclear weapons systems will be interviewed by a medical officer, [and] the medical and psychological history of each man's family will also be checked." Through this procedure, it was hoped that the mentally unstable element would be weeded out of the 
armed forces, especially in the departments working directly with nuclear weapons, to "reduce the chance of a nuclear accidental war to the vanishing point." Readers were reminded that this was not a fail-safe method: "there is always a chance of an honest mistake, a misunderstanding, or a plain blunder." 98 Because the regulation was written and applied to the Air Force, Navy, and Army in response to mental illnesses, one could only assume that accidents of this nature were not limited to the few incidents that were disclosed to the public.

Additional measures to prevent accidental war were also enacted by Defense Secretary McNamara. It was reported that as a result of the continued public concern about nuclear weapons being used unintentionally or without the proper authorization from the highest echelons of government, a new "controlled response" was being enacted, called Positive Control. "Especially applicable to SAC's ICBM and manned bomber elements," it necessitates a voice confirmation from the President of the United States to enable the "multiple safeguards" of a nuclear weapon. ${ }^{99}$

Perhaps in response to this information, U.S. News and World Report devoted a full-page discussion to the reliability and safeguards of missile defense in the "age of the 'push-button war.'” Lieutenant General Thomas P. Gerrity, Deputy Chief of Staff of Air

98 "The Death Wish," Newsweek, December 10, 1962, p. 53. A missile base employee in Fort Collins, Colorado was reported to be mentally unstable. Although the article does not state whether he was a contractor or member of the Armed Forces, it was reported that the man shot his wife three times in the stomach and barricaded himself in a barn to prevent getting caught (he was eventually apprehended), This incident re-enforced public belief of human instability and its possible consequence to accidental war. "Missile Base Worker Held In Shooting of His Wife," Wyoming State Tribune, May 23, 1960, p. 1.

99 Elton C. Fay, "Millions Spent to Prevent Accidental Atom War," Rapid City Daily Journal, October 22, 1962, p. 1. 
Force Logistics answered questions to try to assure Americans of weapon safety. He promised readers that because there were a combination of controls run by both machine and humans, missiles could not be launched accidentally or by one person. In addition, Americans were assured that the number of serviceable missiles in the U.S. arsenal was carefully calculated to withstand a first strike and maintain a successful retaliation. ${ }^{100}$

The strength of the United States arsenal as a deterrent and its readiness for war were tested during the Cuban Missile Crisis. On October 22, President Kennedy informed the American public that the Soviet Union was "building bases in Cuba 'to provide a nuclear strike capability against the western Hemisphere." A blockade was enforced and went unchallenged by the Russian fleet. Eventually Khrushchev backed down and withdrew the weapons. Unannounced and making Khrushchev's surrender appear unconditional was the U.S. withdrawal of Jupiter IRBMs from Turkey. ${ }^{101}$

After 1962, fear of an accidental war diminished, but it did not disappear. Nikita Khrushchev, as portrayed by the press, was unreliable, untrustworthy, and possibly fanatical-therefore a real threat to global peace and security. ${ }^{102}$ The Cuban Missile

100 "Push-Button Arms Take Over," U.S. News and World Report, December 17, 1962, pp. 79-83.

${ }^{101}$ LaFeber, Chapter 10. The Jupiter was the direct decedent of the Army's Redstone missile. It had a liquid propellant, was able to travel 1,500 miles, and had a 1.44 megaton yield warhead. It was only in service for a short time: from 1960-1963. Lonnquest, pp. 259-265. By February 11, 1963, it was announced that the 165 IRBMs (Thor and Jupiter missiles) would be removed from England and Italy as well-they were replaced by Polaris-carrying submarines.

102 "Is Khrushchev Another Hitler?" U.S. News and World Report, October 30, 1961, pp. 38-46. Although this article was published before the Cuban Missile Crisis, it must have still been fresh in the minds of readers, given current events. Authorities who voiced their views of Khrushchev in the article were also not likely to have changed their minds. In 
Crisis demonstrated nuclear war was still a possibility, but there was still hope. The New York Times Magazine reported that a "hot line" connecting Moscow to Washington D.C. had been installed to quicken communication between the two countries, reducing the possibility of accidental by opening communication. War was averted, but anxieties were heightened. A British military expert described the uneasy peace shortly after the crisis: "the peace of the world is maintained by fear," with each side ready to inflict damage to the other. "Inherent to this high state of readiness, however, is the risk of accident either from technical malfunction or through miscalculation." ${ }^{103}$ Because an accident has not already happened through ten years of deterrence, people were becoming complacent, and that was the real danger. The Reader's Digest, however, was doing what it could to calm the fears of its readers, painting a "reassuring picture" of the precautionary measures that have been taken to avoid an accidental nuclear war. By referencing a past accident, the magazine traced step-by-step procedures that were implemented to avoid future errors. After describing the Five Step Positive Control system, the article lists possible scenarios, which could trigger an accidental war and what has been done to assure that those scenarios were never played out. ${ }^{104}$

The first two years of the decade were trying years for Americans: The Berlin Wall was built in the Summer of 1961, the Soviet Union had broken the "three year

fact, the Cuban Missile Crisis further solidified the arguments against trusting Khrushchev, and classifying him as a "madman."

${ }^{103}$ C.N. Barclay, "A Very Real Risk-War by Accident," New York Times Magazine, May 5, 1963, p. 17.

${ }^{104}$ Donald Robinson, "How Safe is Fail-Safe?" The Reader's Digest (May 1963): 91-94. 
unofficial treaty" on nuclear testing in September of the same year, Kahn made them think of their world in different—and insecure - terms, and civil defense measures were increasingly encouraged. At the same time, the successful resolution of the Cuban Missile Crisis-the ultimate "victory" of the United States over the Soviet Union without going to war-reassured Americans about the mental stability of its military and government leaders. The conflict also demonstrated that real threat of nuclear war would deter the enemy: Nuclear deterrence worked. Although the fear of "push button" technology and catastrophic accidents were overcome, Americans did not recover from their fear of nuclear war. ${ }^{105}$ This fear would fluctuate with the international situation until the end of the Cold War. The years 1957 to 1962 , however, played a critical role in the acceptance of missile warfare, Buck Rogers' technology, and nuclear deterrence.

${ }^{105}$ There were still doubts about the role of automation, but those doubts centered on its role in society. "Is the Computer Running Wild?" U.S. News and World Report, February 24, 1964, pp. 80-86; Virgil M. Rogers, "Does Automation Call for New Solutions?" The PTA Magazine, (June 1964): 7-9. 


\section{Chapter 3}

\section{Atomic Pearl Harbor}

Few events in recorded history have had more profound effect upon the affairs of nations than the almost simultaneous birth and subsequent marriage of the intercontinental ballistic missile and the thermonuclear warhead. This is Genesis once more-the beginning of a strange and evil world populated by the fast-breeding, continuously evolving missile offspring of the nuclear Adam and the electronic Eve. ${ }^{1}$

Soviet one-way suicide bomber flights to drop atomic bombs on the United States were considered a serious threat since the late $1940 \mathrm{~s}^{2}$ Periodicals predicted an "atomic Pearl Harbor" which opened the debate of American vulnerability, and defense policy was based on the premise of surprise aerial attack. ${ }^{3}$ Civil defense was initiated to prepare Americans for an attack. ${ }^{4}$ But in 1951, President Harry Truman told reporters that the Air Force admitted, "it was impossible to prevent the bombing of [the United States] ... and

\footnotetext{
${ }^{1}$ Thomas L. Martin, Jr., and Donald C. Latham, Strategy for Survival, (Tucson, 1963), p. 14.

2 "Defense Against Atom-Bomb Blitz? None Yet," Newsweek, November 14, 1949, p. 30 .

${ }^{3}$ When polled, seventy-three percent of Americans believed that if the United States should get into another war American cities would be bombed. Fifty-eight percent of those polled thought about the dangers of a bomb attack. Almost one-third of those that gave the problem thought did not know or think there was anything that could be done for protection. George H. Gallup, The Gallup Poll, vol. 2 (New York, 1998), pp. 916-917.

4 "The Missile Standoff: War Without Profit Promises a New Epoch," Time, July 30, 1956, p. 11.
} 
that such bombings would undoubtedly be atomic in nature." Technological advances and missile development dictated change in American civil defense procedures leaving many to question the effectiveness of both defense strategy and civilian defense.

In reaction to an increasingly hostile world situation Truman initiated the hydrogen bomb project in January 1950, and in December of the same year, designated the Nevada Proving Ground for national atomic testing. On January 12, 1951, he signed a bill creating the FCDA. ${ }^{6}$ Less than ten days later, the first atomic test was conducted at Frenchman Flat. ${ }^{7}$ These executive decisions reinforced the belief of another war-a prediction already made popular by magazines.

Public reactions to and participation in civil defense throughout the early Cold War period were directly linked to changes in defense technology. Public belief in protection and survival diminished as weapons became more powerful and accurate. Often described as apathy, the rapid development of new weapon systems, the threat of Armageddon, and the apparent lack of defense against such weapons made Americans

5 “Civil Defense News," Bulletin of Atomic Scientists 7 (June 1951): 192.

${ }^{6}$ Following the start of the Koran War, Stewart Symington, National Security and Resources Board (NSRB) Chairman, proposed to Truman that a FCDA should be created. Symington's interest in national security is evident throughout the civil defense debate of the 1950s, and, as noted in Chapter 2, he was especially vocal about the risk of accidental war.

${ }^{7}$ A. Costandina Titus, Bombs in the Backyard: Atomic Testing and American Politics, rev. ed. (Reno, 2001), p. 55. After 1955 the Nevada Proving Ground was officially changed to the Nevada Test Site. 
feel hopeless about surviving a nuclear war. ${ }^{8}$ Arguments both for and against civil defense were placed within a deterrent context: preparation for nuclear war would deter Soviet aggression or would heighten Soviet fears of possible American attack-perhaps leading to preemptive war against the United States.

By 1950, the tense international arena and decisions made by the Truman administration regarding atomic energy made Americans eager (and in some cases enthusiastic) to participate in civil defense. This was evident even before the creation of the Federal Civil Defense Administration (FDCA). Public enthusiasm for civilian defense was demonstrated when the Atomic Energy Commission (AEC) and the Department of Defense released The Effects of Atomic Weapons. Demand was so great for information regarding preparedness that the book became a best seller within the first week of its release. The "relatively unknown and terrifying effects of atomic weapons" had monopolized the attention of the public and contributed to the book's success. ${ }^{9}$ But government publications concerning atomic weapons were limited and often sanitized. The book was the most informative to date regarding atomic defense and self-protection, but described post-attack scenarios in controlled environments. ${ }^{10}$ This approach to

\footnotetext{
${ }^{8}$ Gallup Polls taken as early as 1950 (before the development of the hydrogen bomb) indicate that Americans were interested in negotiating atomic control with the Soviet Union: 68\% thought an agreement worth trying. George H. Gallup, The Gallup Poll, vol. 2 (New York, 1998), p. 895. In 1963, polls reflect most Americans agreed with disarmament: $63 \%$ agreed that their should be a test ban treaty, and $46 \%$ believed that the United States should disarm nuclear weapons if the Soviet Union also agreed to do so. George H. Gallup, The Gallup Poll, vol. 3 (New York, 1998), pp. 1837, 1839.

9 “How Bomb-proof a Shelter?" The Economist, August 19, 1950, p. 367.

10 “Atomic Handbook is Best Seller," Life, August 28, 1950, pp. 26-29.
} 
informing the public about atomic weapons would continue throughout the decade and become a major concern. Limited information about weapon destruction, however, did not limit continued attempts to meet the challenge of protecting civilians. Changing technology resulted in changing protective procedures.

Doctors around the world were concerned about civilian defense against atomic attack since the atomic bombing of Hiroshima and Nagasaki. One of the first forms of civil defense they recommended was "duck and cover." Examination of atomic bomb victims showed that people that were shielded from the bomb's blast survived and were not as badly injured as those who were in the direct path of the explosion. Ducking to the ground and covering one's head, it was believed, would sufficiently shield victims of an atomic blast from blindness and major burns to the face. The effectiveness of "duck and cover" was challenged as weapons rapidly became stronger.

Government authorities immediately tried to dispel public anxiety about the effects of the atomic bomb by comparing it to conventional weapons. In early 1950 , Richard Gerstall, a former Navy Lieutenant Commander and a participant at the Bikini atomic tests, claimed that despite radioactivity, the bomb had the same effects as conventional weapons." "Blast and heat, which—although of far greater magnitude--are

${ }^{11}$ Richard Gerstall, "How You Can Survive an A-Bomb Blast," Saturday Evening Post, January 7,1950 , p. 23. This was one of the earliest articles written about the possibility of self-help in the Nuclear Age. While investigating the effects of the atomic bombing of Japan, medical experts described injuries similar to damage done by conventional weapons, "but with certain added factors"--such as increased heat, light, and radiation. Careful reading of the medical repot, however, reveals the differences of such weapons. The final report suggested "dispersal of facilities" and "organization of emergency work" to prepare for such a catastrophe. These suggestions will be revisited several years later. U.S. Congress, Hearings Before the Joint Committee on Atomic Energy, $81^{\text {st }}$ Congress, 
the same forces as in the ordinary bomb, and what is defense against the blast and heat of one is a defense against the same two forces of the other." Like doctors before him. Gerstall recommended a form of duck and cover for individual protection. Gerstall's extensive article was a reassuring, low key, attempt to demonstrate that controlled atomic testing had proven that they could be used in war like conventional weapons and Americans could protect themselves against them. Later the same year, Time also suggested a form of duck and cover as a means of protection. Easy to teach and to learn, the magazine advised parents to train their children this simple survival technique. "Can Junior fall instantly, face down, elbow out, forehead on elbow, eyes shut? Have him try it tonight before he gets into bed," parents were told. "A little practice and an understanding of the situation might save the life of a small boy born into the Atomic Age."12 The atomic bomb had ushered in a new age filled with rapid technological change. Indeed, it was evident to many that duck and cover was obsolete almost as soon as it was initiated, and it was clear that this form of civil defense would not protect cities and industrywhich were increasingly thought to be vulnerable. ${ }^{13}$

Dispersing the populations of American cities and industry from its epicenter was believed by scientists and urban planners to be the only practical means to prevent

$\overline{2^{\text {nd }}}$ sess., Part 2, March 30, 1950 (Washington D.C., 1950), pp. 36-47. These initial studies were based on (and limited to) damaged caused by approximately 20,000 tons of TNT.

12 "Civil Defense: The City Under the Bomb," Time, October 2, 1950, pp. 12-14.

${ }^{13}$ The vulnerability of American cities was the focus of a Congressional Hearing a year before Truman created the FCDA. U.S. Congress, Hearings Before the Joint Committee on Atomic Energy, $81^{\text {st }}$ Congress, $2^{\text {nd }}$ sess., March 23, 1950 (Washington D.C., 1950). 
complete devastation if an atomic Pearl Harbor should occur. The need to "change the pattern of city and country" became clear in 1949 when Russia broke the U.S. atomic monopoly. American cities, it was envisaged, would be the primary focus of the next war, but "fringe cities" could be the answer to atomic bombardment. ${ }^{14}$ With proper planning, manufacturing and housing would be located outside of "downtown." Dispersal was the topic of the September 1951 issue of the Bulletin of Atomic Scientists. ${ }^{15}$ Existing urban centers unable or unwilling to conform completely to a new city design were urged to convert unused areas or slums to parks as "buffer zones" against firestorms. Dispersal became sophisticated in design as it became more popular. Donald and Astrid Monson, a husband and wife team of city planners with the Detroit Housing Commission, wrote that not only would dispersal of existing and developing cites make them less vulnerable to attack, it would also make them more desirable places to live and raise families.

14 "92 Atom-Bomb Targets for Russia in U.S." U.S. News and World Report, October 7, 1949, pp. 16-19. The idea that American cities would be primary targets by Soviet bombers permeated the American psyche. Beginning in 1950,73\% of Americans polled believed that cities would be bombed in another war. When asked in 1950 "how much chance do you think there is of your community being attacked with atomic bombs," $53 \%$ answered good or fair chance. In 1951, half of those polled did not think their community was safe in an atomic war. By 1954, 57\% believed there would be a good to fair chance of their community being attacked by hydrogen bombs. George H. Gallup, The Gallup Poll, vol. 2 (New York, 1998), pp. 916, 950, 967, 1230.

${ }^{15}$ Psychologist Irving L. Jarvis foreshadowed the problems of dispersal in 1950 . He suggested that to "convince dissident industrial workers that they should accept relocation is to arouse their anxiety. Strong emphasis upon the dangers of atomic bomb attacks and on the avoidance of this danger by taking advantage of the opportunity to move to a less vulnerable section of the country may appear to be a successful way to overcome resistance to dispersal." Irving L. Jarvis, "Psychological Problems of A-Bomb Defense," Bulletin of Atomic Scientists 6 (June 1950): 256-262. 
Dispersal, although a good idea in theory, was not readily embraced by city dwellers and was seen as problematic. As noted by The Economist, it would mean indefinite loss of the urbanite's "bread and butter." 16 The increasing radius of destruction of thermonuclear weapons annihilated the usefulness of city and industry dispersal. The end result was confusion and doubt about civilian defense and dispersal would be a policy that would be debated throughout most of the 1950s. Although not a perfect plan, supporters believed it would alleviate some of the unnecessarily "gruesome horrors that would be left in the wake" of atomic attack-images "better left to the imagination."17

To compound the confusion concerning nuclear weapons, President Eisenhower's first Civil Defense Administrator Val Peterson often made candid and sometimes alarmist statements in an effort to inform the public of the dangers of atomic weapons. It was his hope that blunt language would provide the impetus needed for national cooperation in civil defense. In an extensive interview with U.S. News and World Report, Peterson told reporters that since observing Operation Ivy (the hydrogen tests at Eniwetok Atoll in 1952), "I've been going up and down America saying the people in these congested areas

16 "How Bomb-Proof a Shelter?"

${ }^{17}$ Goodhue Livingston, Jr., "The Blight of Our Cities," Bulletin of Atomic Scientists 7 (September 1951): 260-262. Dispersal, admittedly, was not practical for urban planning, but it became an integral part of the communications network during the 1960s, eventually creating what we now know as the Internet. It was during this time that the Air Force was interested in building a "flexible response" system for communications, command, and control that could "survive" a nuclear attack. They dispersed information in an effort to avoid infiltration during war. Janet Abbate, Inventing the Internet, (Cambridge, 1999). It is worth pointing out that the language used for protecting the inanimate is the same for protecting the population. 
have only three choices-dig, die, or get out." ${ }^{, 18}$ His choices could hardly have been encouraging. Perhaps this is why an editorial in Harper's Magazine referred to civil defense as a "farce."19

The development of thermonuclear weapons led civil defense plans to change yet again - this time to city evacuation. The increased yield of the hydrogen bomb enlarged the radius of destruction to about twelve miles (up from a two-mile radius created by the atomic bombs dropped at Hiroshima and Nagasaki). The area of devastation would wipe out an entire city, making both duck and cover and dispersal obsolete. Evacuation was not a new concept and was evaluated by psychologist and consultant to the RAND Corporation Irving L. Jarvis in 1950. His concern, however, was not civilian defense effectiveness, but of "unauthorized" exodus "if attacks occur before war has been declared." Jarvis' apprehension regarding authorized evacuation was the "social and psychological problems" associated with such an undertaking. Although he did not suggest an alternate means of evacuation, Jarvis did imply that detailed plans needed to be formulated for such an emergency. ${ }^{20}$

18 "If H-Bomb Comes-What You Can Do About It," U.S. News and World Report, April 8, 1955, pp. 72-78. The hydrogen bomb explosion at Eniwetok Atoll "blew a whole in the island 175 feet deep and created a crater a mile across and made a whole big enough for 14 Pentagon buildings." Its colossal destruction exceeded scientists' expectations.

19 "Personal and Otherwise: On Running for Cover," Harper's Magazine, 211 (October 1955): 24-26. In the same issue, Bernard Brodie, criticized civil defense measures, calling them "ludicrous." Bernard Brodie, "Strategy Hits A Dead End," Harper's Magazine, 211 (October 1955): 33-37.

${ }^{20}$ Irving L. Jarvis, "Psychological Problems of A-Bomb Defense." Jarvis also mentioned the need for shelters to protect Americans who cannot evacuate. 
Many Americans questioned the practicality of evacuating an entire cityespecially after the mid-1950s when the effects of thermonuclear weapons became known. Although radar networks were improved and placed as far as Northern Canada and far offshore at "Texas Towers," they provided little assurance of enough warning to evacuate entire cities threatened by these megaton "block-busters." Indeed, the prediction of the inevitability of the development of the intercontinental ballistic missile rendered DEW and SAGE "multimillion-dollar white elephants." This skepticism came to light when San Francisco distributed the evacuation booklet It's Your Life. The booklet assumed there would be "sufficient warning time to make evacuation practicable," but it neglected to mention the time delay for the emergency broadcasting system CONLRAD (control of electromagnetic radiation) to begin operation (negating its effectiveness). There were also severe problems with evacuation routes (one of the bridges was off limits to evacuees and two others merge just past city limits). ${ }^{21}$ In fact, these problems continued to plague evacuation policy across the country, and the increased intensity of super weapons further compounded urban civil defense problems.

Shelters had been discussed as a viable option for civil defense since the FCDA was formed, but they were not viewed as practical. They were not federally recognized as a solution because of the price of their construction. The government encouraged dispersal and evacuation because they cost little to nothing - and at the time, they may

${ }^{21}$ Gene Marine, “Our Stupid Civil Defense," Nation, February 9, 1957, pp. 111-115. 
have seemed logical. ${ }^{22}$ To provide shelter for millions of people, on the other hand, did not make fiscal sense, both the executive and Congress argued. ${ }^{23}$ As dispersal of existing cities began to be viewed as impossible - although it was beginning to happen on its own in newer cities with the development of suburbia-evacuation was quickly discredited. It was missile technology that began to reshape thinking about shelter construction as the most logical means of civilian defense.

FCDA strategy for civilian protection shifted from a policy of dispersal to evacuation to shelter as information about the magnitude of thermonuclear weapons circulated. Although shelter had always been discussed, it too transitioned as weapons technology advanced. When the federal government began investigating the effects of atomic weapons, bomb shelters were suggested as an effective shield against an atomic blast. When hydrogen weapons were developed, bomb shelters were declared futile. Instead, shelters were discussed within the context of fallout protection-not blast protection. ${ }^{24}$ Nuclear physicist and leader in civil defense planning Ralph E. Lapp commented on this transition and its effect on civil defense policy:

${ }^{22}$ The persistence of the FCDA to use evacuation as a form of defense might have been a result of outdated information. In the atomic years the public was told that their automobiles would be an effective form of protection. "New Defense Against Atom Bomb," U.S. News and World Report, September 21, 1951, pp. 11-13.

${ }^{23}$ Proponents of shelters, while recognizing their expenditure, argued that the price was still only a fraction of the entire military budget of the United States, See: Gene Marine, "Our Stupid Civil Defense," Nation, February 9, 1957, pp. 111-115.

${ }^{24}$ The emphasis on fallout protection became especially apparent in 1961, when the Rockefeller Center in New York City led a national campaign to designate fallout shelters in cities throughout the United States. "Civil Defense: For Survival," Time, October 6, 1961, p. 24. 
The rapid succession of mounting hazards--the megaton, fallout, and ballistic missile - forms a terrible triad. Civil defense planners have never been able to keep up with the tempo of arms development and very often they were hamstrung in their efforts to obtain the necessary information from the Defense Department and the Atomic Energy Commission. . . . The triple impact of megatons, fallout, and missiles convinces most Americans that their lot will be a hopeless one should the United States be subject to a nuclear attack. ${ }^{25}$

The increased threat of more powerful weapons led to shelters being viewed as the most feasible means of protection. The Nation noted that it had become obvious that "Fallout has now made shelter, not evacuation, the preferred method of protection." Fallout was government knowledge since 1954, but the "only existing FCDA shelter program is an occasional statement urging the public to build (and pay for) its own shelters." ${ }^{, 6}$ Fallout, however, was not the only argument against evacuation: the increased yield from hydrogen warheads and the reduced warning time as a result of the "impending ballistic missile" would render evacuation for the masses "hopeless.,"27

${ }^{25}$ Ralf E. Lapp, "Fallout and Home Defense," Bulletin of Atomic Scientists 15 (May 1959): $187-191$.

${ }^{26}$ Marine. This remark was quoted from Val Peterson in his testimony at the Holifield Committee Hearings. An Office of Civil Defense Management survey revealed that one million of the nation's five million households had built a shelter. "Civil Defense: Who'd Survive?" Newsweek, August 7, 1961, pp. 48-49. In the state of Maine, tax assessors ruled that shelters were home improvements and would be taxed as such. "Shelter Boom," Newsweek, September 18, 1961, pp. 31-32.

${ }^{27}$ Paul G. Steinbicker, "Shelter or Evacuation?" Bulletin of Atomic Scientists 13 (May 1957): 166-168. Steinbicker did not argue against evacuation, although he was a proponent of shelter. His contention was any action was better than no action at all. Evacuation would save lives-however few. On the other hand, shelters may not save lives because their construction was not policy. 
In 1956, a Congressional Committee headed by California Representative Chet Holifield, set out to investigate what the federal government, states, and cities were doing about civil defense and if it was actually useful. After a year of testimony, their findings were alarming. The Atomic Energy Commission (AEC) was releasing information on the biological and medical effects of radiation that was seven to eight years old. In addition, many of the local plans for evacuation "took no account of the fall-out danger." Because of the intensity of thermonuclear weapons and the approaching development of the guided missile - both land based and submarine launched - as a means of delivery, the Congressional Committee concluded that the only "practical measure" of protection was shelter. It would not only be a "refuge from the immediate explosion effects, but a base of operations or staging area for the next phase in recovery action. ... Shelters may be the only 'clean' areas for some time after an attack." 28

Civilian defense procedures changed to meet the challenges of war waging technologies, and public attitudes toward civil defense also changed to reflect fears of these new weapons systems. Many Americans not only became doubtful of their ability to survive the next war but also questioned the desire to live in the post-war world that would result. ${ }^{29}$ In 1951, the first Civil Defense Administrator Millard F. Caldwell Jr. did

${ }^{28}$ Mary M. Simpson, "A Long Hard Look at Civil Defense," Bulletin of Atomic Scientists 12 (November 1956): 343-348.

${ }^{29}$ Periodicals predicted that the next war would begin with a Soviet surprise attack and be fought on American soil. World War III continued to be reported for several years. In 1955, U.S. News and World Report ran an article comparing their prediction of the next war from 1947, 1951, and 1955. "1947 to 1955-World War III, Russian Style: Who is Winning?" U.S. News and World Report, December 2, 1955, pp. 19-25. 
not calm public fears when he told readers it was Russia's goal to "beat this country into the ground." He prophesied an alarming scene:

Sabotage could be in place in this country ready to move at any time, to foul up traffic, stop utilities, poison water, spread biological warfare, turn loose chemical gases, and all simultaneously at the time of a given attack on a certain community. There will not be one blast, as I visualize it. There will be a number of cities hit at the same time. ${ }^{30}$

Although Caldwell was Civil Defense Administrator, he may have exasperated public concerns with his comments. In fact, his interview with U.S. News and World Report was quite horrifying. ${ }^{31}$ Readers were told that the Air Force-believed by many to be the primary defense against attack-acknowledged that "in optimal conditions they cannot hope to stop more than three out of ten" interceptions on the United States and anything within a given distance of ground zero "is gone."32 Perhaps most frightening was Caldwell's "glaring illustration" of the United States after an enemy attack:

Take the Northeast-Massachusetts, Connecticut, New Jersey, New York, and Pennsylvania. Suppose they were hit. You'd have a great rush of refuges to Vermont and New Hampshire and Maine. But the only way most food can get to Vermont, New Hampshire and Maine is to go through these stricken areas. Naturally, New Jersey is going to want to stop the food in New Jersey and New York will want to stop it there. The whole New England area is thereby cut off. Consequently you have the

\footnotetext{
30 "If Soviet A-Bombs Come-_," U.S. News and World Report, October 12, 1951, pp. 3641.

${ }^{31}$ His prediction resonated with many Americans who where all too aware of Senator Joseph McCarthy's claims of Communist infiltration and the power of subversive activity.

${ }^{32}$ According to one analyst at the time, the Soviet Union also considered SAC to be the "pre-eminent" force behind U.S. defense. Raymond L. Garthoff, "The Soviet Image of the Enemy," Military Affairs 21 (Winter 1957): 161-174.
} 
business of organizing this so that whatever happens and wherever it happens you can meet the need. ${ }^{33}$

If an attack occurred, readers were told, the United States would in no way be able to meet an emergency of such magnitude. This fueled a vulnerability argument among Americans. $^{34}$

Civilian defense planning was complicated by fallout (a term relatively new to non-scientists). The AEC was hesitant to release information regarding its threat potential. By January 1951, however, "deadly dust"-or radioactive fallout-was beginning to be discussed in news magazines. Time explained to readers what fallout meant within the context of Soviet attack by comparing the difference between surface and air detonation. Air detonation (which was used in the bombings of Hiroshima and Nagasaki) had the most heat and blast damage but yielded little fallout and was therefore considered "clean." Consequently, this would most likely not be the means of Russian

${ }^{33}$ Ibid.

${ }^{34}$ U.S. News and World Report showed readers a two-page map of the United States marked with "critical" and "other" target areas. The critical target areas were concentrated in the northeast. "Big Talk of Atom Defense, But-Hitting Back is Still America's Main Plan," U.S. News and World Report, October 2, 1953, pp. 27-29.

This scenario was often illustrated in popular magazines. A map in U.S. News and World Report demonstrated the ineffectiveness of American borders against Russian submarine launched ballistic missiles (SLBM). Their strategy, it was believed, would be to surround the Atlantic and Pacific borders of the United States and simultaneously launch up to three atomic missiles against key cities as far as six hundred miles inland. "How Russian Submarines Could Hit U.S." U.S. News and World Report October 3, 1952, pp. 36-37. Submarine attack was also used against the United States in Alas, Babylon and Triumph. As a result of the underwater detonation of the Baker tests (Operation Crossroads) in July 1946, scientists and defense experts were surprised to see the complete destruction of a mock navy, and the test gave rise to the belief that an atomic bomb could be detonated underwater to cause coastal tidal waves-or tsunamis. 
atomic bombing, readers were told. Rather, they were warned that because Russia's real objective was to destroy target civilian populations they would use ground burst bombsor "dirty" bombs. Readers were warned the enemy might deliberately sacrifice the blast effect of their weapons to maximize human loss through fallout contamination. ${ }^{35}$ Americans were scrambling for civil defense information.

Possibly to alleviate fears of American vulnerability, by the fall of 1952, popular magazines began printing articles about the strike capability of the United States and its superior fighting power. Readers were informed that "flattops" (aircraft carriers) within the Mediterranean and North Atlantic made possible "three hours flying time" to destroy Russian cities. Pictured are flattops in the North Sea and Mediterranean with eight arrows from each ship. Each arrow points to a different Soviet city. And like American claims about Soviet intentions, target cities are chosen for industrial and military capability and vital natural resources. ${ }^{36}$ A little over one year later, Americans were told that attack time of the U.S. fleet was shortened to two hours. The picture used in this article-unlike its predecessor-demonstrated the destruction of each Russian city with a mushroom cloud.

35 "The Deadly Dust," Time, January 1, 1951, p. 41. Fallout was discussed in popular magazines, but it was commonly referred to as dust. As a result the public may have not viewed it as harmful. Four years later most Americans still did not know or understand what fallout was. When Americans were asked in 1955 what was meant by "fall-out" of a hydrogen bomb, $9 \%$ were incorrect or vague, while $74 \%$ didn't know. George H. Gallup, The Gallup Poll, vol. 2, p. 1322.

36 "Russia Can be Hit from Two Seas," U.S. News and World Report, September 26, 1952, pp. 13-15. The power of the U.S. fleet was used in an advertisement campaign by Grumman. It pictures a plane flying over the Forrestal aircraft carrier and a plane flying over the peninsula of New York City (they appear to be similar in shape). It links the company to the Navy rather than a product. "Progress Needs Protection," Grumman ad, Newsweek, December 12, 1955, pp. 4-5. 
Readers were promised that SAC's "plans for wrecking Russia's war-making ability already are laid out in meticulous detail," and Soviet "awareness that their Communist empire can go up in smoke within a matter of hours provides the greatest deterrent to a Communist-inspired world war." ${ }^{37}$ While shortened reaction times were meant to assure Americans about the effectiveness of the U.S. war machine, it simultaneously heightened awareness of enemy capability.

Concerned about the "overly sensational reports" of atomic destruction of cities, Ralph E. Lapp suggested that a full-scale city be constructed and "demolished with an Abomb" at Frenchman's Flat at the NTS. This demonstration, Lapp argued, would aid civil defense workers and educate Americans who were "dangerously hysterical" about such an attack. ${ }^{38}$ A year later a "test town" was built and "wrecked" outside Washington D.C. "Rescue City" was constructed at a cost of $\$ 200,000$ and bombed to give civil defense workers "practical training in their jobs." How helpful this drill actually was, however, is questionable. Unlike Lapp's suggestion, the city was not destroyed by an atomic bomb

37 "If Attacked, U.S. Can Drop A-Bombs on Russia in 2 Hours," U.S. News and World Report, October 23, 1953, pp. 19-22. The power of SAC is demonstrated in an advertisement by Sperry Rand Corporation. Like the Grumman ad, this too connects itself with the power and sophistication of SAC more than selling a product to readers. It shows a dramatic picture of a Boeing B-47 mock bombing the city of Sacramento in a drill. Its navigation system built by Sperry made the direct hit possible. "SAC's rigid competition is dramatic proof of what the Air Force is doing to discourage possible aggressor-by making certain an aggressor nation will be hot surely and swiftly should it take belligerent action." "City of Merced' Crew Wins SAC Competition," Sperry Rand Corporation ad, Newsweek, December 12, 1955, p. 95. Although this ad was meant as reassurance, its image must have been disturbing to some, because it invited images of war rather than protection.

38 “Atomic Eye Opener," Newsweek, July 23, 1951, p. 82. 
but "wrecked as [conventional] bombs would wreck it," and as pictured in U.S. News and World Report, it did not appear different than normal demolition. The drill was held on a clear sunny day without any chaos, radioactive fallout, death or injury, and appeared to be as sanitized as the government book The Effects of Atomic Weapons printed two years prior. ${ }^{39}$ In contrast, "Operation Doorstep" was conducted in 1953 and used actual atomic bombs. The purpose of the exercise was to determine the effectiveness of civil defense preparation by bombing two "typical' frame houses." Constructed at Yucca Flat, NTS, they were fully furnished with modern home conveniences and had mannequins placed inside to test the bomb's effect on humans. Because the dummies were unscathed, the FCDA concluded that basements would be effective bomb shelters in wooden frame homes. $^{40}$

Despite these tests, volunteer participation in civilian defense was low. This may have been a result of conflicting reports about the ability of Americans to protect themselves. The FCDA distribution of the booklet Operation Doorstep, which reported the results of the atomic tests in Yucca Flat reflected these conflicting reports. The information within it-especially concerning radioactive fallout-was clearly sanitized and reporters were easily able to discern that the truth was not fully released. Time claimed that the "elaborate booklet" was "less than frank" and not realistic, nor did the tests really live up to a real atomic explosion. The homes did not have masonry that may

39 "If An Atom Bomb Hits-What Happens to a U.S. City," U.S. News and World Report, July 4, 1952, pp. 26-27.

40 “Operation Doorway," Time, July 6, 1953, p. 67. 
have crashed into the basement nor did they have electricity, gas, wiring, or anything that might catch fire. In addition, the booklet failed to explain the dangers of the "radioactive dust" that "settled over both houses." Questions were raised about fallout when it was noted that three hours after the explosion the further house was so contaminated "it could only be entered for a few minutes." Reporters found this to be alarming because this information meant "its [radioactive] intensity must have been enormously higher just after the dust fell," people "huddled in basement shelters would certainly have been killed by this silent, insidious force." Time suggested that a "persistent, frank discussion of the ways of the atom bomb" by the FCDA would both enlighten Americans and encourage participation in civilian defense. ${ }^{41}$ Forthright information, however, would not be forthcoming. As Newsweek explained to readers, "the AEC feels [the truth] is bad business, nationally and internationally, to talk too much about the frightening effects of atomic energy. It feels that panic might do more harm than the bomb." ${ }^{42}$ Like with the secrecy surrounding missiles, the lack of information about atomic weapons and fallout resulted in Americans filling in what they did not know with what they thought to be true. Government transparency, however, did not motivate the public to participate in civil defense. The truth was too difficult to confront.

${ }^{41}$ Ibid. Concern about low public participation in civilian defense organizations and practical preparedness was also reflected in a study printed in Public Opinion Quarterly. The study indicated that more information about the dangers of atomic war were necessary to motivate people to participate. William Abbott Scott, "Attitudes Toward Participation in Civil Defense: An Analysis via Psychological Constructs," Public Opinion Quarterly 16 (Fall 1953): 375-385.

42 "Atomic Light on the Desert . . And Answers to Fearful Questions People Ask," Newsweek, March 21, 1955, pp. 30-31. 
In June 1955, the FCDA again tried to prepare the nation for atomic war with a mock drill: Operation Alert. ${ }^{43}$ Staged as a "hypothetical raid," Operation Alert assumed that the Soviets had an "old fashioned nuclear stockpile," which Life noted was a "shockingly shortsighted assumption." Government planners argued that the Soviet Union may not have hydrogen bombs. The magazine disagreed, observing Russia already conducted two hydrogen tests. This information revealed that Operation Alert was "unrealistic:" even a ten-megaton bomb was "now only a nominal weapon." underscored when a Washington D.C., civil defense worker-who was later firedclaimed that the drill was "so inadequate it couldn't cope with a brush fire threatening a doghouse in the backyard." Other civil defense officials ignored the drill, believing it was "useless." Negative comments by civil defense authorities and the unrealistic

${ }^{43}$ Operation Alert was a yearly exercise organized by the FCDA beginning in 1954. Kenneth Rose, One Nation Underground: The Fallout Shelter in American Culture, (New York, 2001), p. 27.

44 “A Confused Alert-But Even A Good One Maybe Obsolete," Life, June 27, 1955, pp. 48-49.

45 "So Much to Be Done," Newsweek, June 27, 1955, p. 21. Ignoring civil defense drills and procedures would continue to happen. Commenting on the complete lack of emergency action during a false alarm, an editorial in Harper's Magazine complained, "Never before has the principal been so clearly stated that our civil defense setup works only because everyone ignores it." "Personal and Otherwise," Harper's Magazine 215 (November 1957): 25-26. Many protested the drill as well. A group of young mothers (with support from their husbands) organized by Dorothy Day, leader of the Catholic Workers, opposed civil defense in support of their "children's lives and refused what they perceived as their victimization by civil defense officials and nuclear strategists." They promoted peace in place of civil defense. Dee Garrison, " 'Our Skirts Gave Them Courage:' The Civil Defense Protest Movement in New York City, 1955-1961," in Joanne Meyerowitz, ed. Not June Cleaver, (Philadelphia, 1994): 201-226. 
assessment of enemy weapons capability kindled doubt of government assurances that Americans could protect themselves.

Gallup Polls of the decade reveal the conflicting fears of Americans toward the relationship between national defense spending and civil defense. Most Americans in the early 1950 s did not believe that the United States was adequately prepared for another war. Seventy-six percent of those polled thought the United States was either "poorly prepared" or "fairly well prepared"-compared to fifteen percent who answered, "well prepared." Forty-nine percent of those polled believed that the United States industries should begin to produce "war equipment on a full-time basis" and "cut" the manufacture of luxury goods such as "autos, refrigerators, [and] television sets." ${ }^{, 46}$ In addition, the majority of Americans polled also believed that a plan for the "total mobilization of all citizens" should be initiated in preparation for another war. ${ }^{47}$ These apprehensions coincide with the increased public discourse of civilian preparedness.

Americans, according to Philip Wylie, author and consultant to the FCDA, were beginning to show signs of panic and hysteria when they confronted the dilemmas of trying to survive nuclear war. He concluded that Americans were "exhibiting on a

${ }^{46}$ George H. Gallup, The Gallup Poll, vol. 2 (New York, 1998), pp. 941, 948. Most of those polled also believed that taxes should be raised to support such expenditures, Ibid, p. $949,969$.

47 "Total mobilization" is defined as: "in case of another war, every able-bodied person would know what war work he would have to do, where he would work, and what waged he would get." $46 \%$ agreed to total mobilization. Ibid, p. 920 .

$86 \%$ of those polled also believed that it was a "good idea to pass a law requiring everyone to carry an identification tag giving his name, residence, and blood type to be used in case of an accident or bomb attack." Ibid, p. 939. 
massive scale a vast variety of 'symptoms' which, in clinical psychology, are known to be results of deeply repressed fear . . . called 'hysterias,' which is a form of self-deceit." Wylie explained that hysteria was "the stratagem for psychological defense against the undesirable, the unknown, the intolerable. ${ }^{.48}$ Newsweek, a few years later, had a similar interpretation: "Americans simply refuse to read stories about nuclear weapons. The whole idea of atomic war is so horrible they just decline to think about it. Lacking facts, they invent fiction." 49

Public apathy toward civil defense was not indifference. Americans were not convinced that anything would be able to protect them from the devastating effects of increasingly destructive weapons, and it was apparent that civil defense could not keep pace with weapons technology. The sense of public hopelessness concerning defense against new weapons can be traced back to 1951. The press reported that "lack of interest in civil defense stems largely from the fatalistic attitude resulting from the well known statement: "There is no defense against the atomic bomb." "50 Ten years later, public sentiment was little changed. Newsweek noted that the "apathetic" could be placed into two groups. The first was the "endless euphoria" group who had the feeling that "nuclear war was so terrible it could not happen." The second expressed the "Armageddon

${ }^{48}$ Philip Wylie, "Panic, Psychology, and the Bomb," Bulletin of Atomic Scientists 10 (February 1954): 37-40.

49 "Atomic Light on the Desert . . And Answers to Fearful Questions People Ask," Newsweek.

50 "Civil Defense News," Bulletin of Atomic Scientists 7 (June 1951): 192. 
attitude," which assumed that if war did happen, nothing would be worth saving. ${ }^{51}$ This fear was later demonstrated in readers' letters to the news magazine. In 1955, Arlene Reuther wrote, "Sure, many people don't read about the [atomic] tests and they are scared; many of us do read about them and we are still scared. We are called panicky and accused of sticking our heads in the sand and that might be half true . ..,52 J.B. Gabrielson was more direct: "Why not an X-bomb, which would blow up all the scientists of the world before they have a chance to blow us up?" ${ }^{33}$ Many felt that survival after a nuclear war would be hopeless.

Although the American public was represented as apathetic, Gallup Polls indicated that most Americans were interested in civil defense. In 1956, Americans were asked whether they would approve a plan that required every man and woman to spend an average of one hour a week doing civil defense work: sixty-four percent agreed. In 1960 , seventy-one percent of those polled believed that a law should be passed to require each community to build a bomb shelter. ${ }^{54}$ Americans were inundated with information about impending Soviet atomic attack and conflicting reports on how to prepare for such an attack. The FCDA told Americans one thing, scientists and other specialists suggested something else, while Congress consistently slashed funding. This happened against the

\footnotetext{
51 "Civilian Defense: Optimists and Fatalists," Newsweek, May 29, 1961, p. 94.

52 Arlene E.D. Reuther, "This 'Messing Around," Letters to the Editor, Newsweek, April 4, 1955, pp. 11-12

53 J.B. Garielson, "This 'Messing Around," Letters to the Editor, Newsweek, April 4, 1955, p. 12.
} 
backdrop of a national policy based on atomic diplomacy and massive retaliation and an international situation, which appeared to be increasingly hostile.

Hornell Hart, an "eminent" sociologist of Duke University, supported public belief that defense against atomic attack from the Soviet "menace," would be futile. Hart was interested in the strike capability of the Soviet Union and the means with which the United States was able to combat such an attack. He dissected and analyzed the five facets of civilian defense: 1) sea and land radar networks, Ground Observation Corps, and the build up of defense armaments; 2) modification of future building to promote blast protection; 3) dispersal of cities and industries; 4) building bomb shelters; 5) evacuation. His conclusions contradicted what many proponents of civil defense had been arguing. The first facet of protection, Hart noted, was contingent on answers to other questions, namely the future military ability of the Soviet Union-especially in regards to missile development (both ICBM and SLBM). "Bomb-proofing buildings" would be negligible, he argued, as a result of "the swiftly increasing explosive power of bombs." Dispersal would be "nullified in two fundamental ways:" it was very slow and would paralyze the nation rather than destroy cities. In other words, if the centers for coal, gas, oil, and electric, were destroyed or cut off, industries would be "useless." Bomb shelters, Hart continued, could be "death-traps and tombs" to those who actually managed to get in them. Those who would be able to emerge from shelters would "find themselves facing the really crucial problems of firestorms, starvation, epidemics, and anarchy." This analysis made apparent that survival would not be likely, let alone desirable.

As dismal as this analysis might be, Hart closed his article with a warning: because of advancing technology, "The [Soviet] Menace Has Grown Worse Since the 
Above Article Was Drafted." Since then the AEC exploded a deliverable hydrogen bomb almost twice as powerful as scientists predicted and the Soviet Union demonstrated "jetpowered intercontinental bombers capable of delivering hydrogen bombs into target areas in the United States." Hart estimated that hydrogen bombs could be built in large numbers at minimal cost. Missile development and Hart's prophesy of a bomb 2,000 times more powerful than the one used at Hiroshima rendered both evacuation and dispersal obsolete. ${ }^{55}$ What was left unsaid but what the data certainly implied was that the best and possibly the only means to combat the disasters of new super weapons was disarmament.

By 1957 disarmament was gaining currency, but it had been consistently discussed during the early 1950s-especially among atomic scientists and religious groups. There were several reasons for this. First, Truman used the atomic bomb as a weapon of diplomacy, which easily transitioned in the Eisenhower administration to nuclear deterrence. Second, the United States government did not feel that the Soviet

${ }^{55}$ Hornell Hart, "The Remedies versus the Menace," Bulletin of Atomic Scientists 10 (June 1954): 197-205. Italics by the author.

To highlight the confusing reports given to readers - even by the well informed - the proceeding article advocates dispersal of industry. "Dispersal of American Industry," Bulletin of Atomic Scientists 10 (June 1954): 196.

Shortly over one year later, a "memo" from Japan was printed in U.S. News and World Report commenting that ten years after the bombing of Hiroshima, people looked healthy and cheerful, had little resentment toward the United States and the city was "hum with activity." This article implied that recovery was possible and nuclear attack survivable. "10 Years After," U.S. News and World Report, August 12, 1955, pp. 98-99.

Newsweek noted, however, that more of the 200,000 survivors of Hiroshima and Nagasaki had more cases of leukemia and cataracts than other Japanese, claiming that the AEC "underplayed the lingering effects of fallout." "Even Deadlier," Newsweek, March 7, 1955, p. 23. 
Union could be trusted to disarm. Third, the domestic climate of fear during the $1950 \mathrm{~s}$ (McCarthyism was still fresh in the American mind) prohibited many from speaking out afraid of being labeled subversive, anti-American, Communist, or sympathizer. As one person argued: "I have found recently that to be an advocate of peace or world government is almost equivalent to advocating the overthrow of the United States government by force. ${ }^{, 56}$ This hostility against non-conformists was evident throughout the decade and into the early 1960s. The disarmament movement did gain ground however, with the founding of the National Committee for a Sane Nuclear Policy (SANE) in 1957. This was aided in part by the "Fallout Scare" that pervaded the scientific community during the same year. ${ }^{57}$

${ }^{56}$ Quoted by a U.S. representative of UNESCO (United Nations Educational, Scientific and Cultural Organization) in Lawrence S. Wittner, Rebels Against War: The American Peace Movement, 1933-1983, (Philadelphia, 1984), p. 222. Boyer also notes that "Atomic war would be the ultimate challenge for the American physician, and he must steel himself for it, whatever the odds. Any other response would be unworthy and unpatriotic. Such was the message of America's medical leadership as the 1950s began." Boyer, Fallout, p. 81.

${ }^{57}$ Robert A. Divine, Blowing on the Wind: The Nuclear Test Ban Debate, 1954-1960, (New York, 1978), Chapter 10.

The Bravo test series at Bikini Atoll in March of 1954, unexpectedly spread "radioactive ash" almost eight thousand miles over the Pacific and contaminated the Japanese fishing vessel, Luck Dragon. This incident made the dangers of fallout a public concern. Public outcry reached an apex when results from milk tests conducted by the Public Health Service showed a hundred percent increase in strontium 90 in only two years. This discovery prompted a Congressional investigation and became front-page news (this fear resurfaced during the Berlin Crisis of 1961). Boyer, Fallout, pp. 80-83. This was a legitimate fear. When test results of a study of baby teeth was released in 1962, it "showed a fourteenfold (sic) increase in the level of strontium 90 in the teeth of children born in 1957 compared with those born on 1949." 
Americans continued to be bombarded with adverse information regarding war and nuclear weapons even though disarmament had gained acceptance. Many of these headlines were meant to assure American supremacy, but they did little to alleviate fears of nuclear catastrophe. One such concern was what strategists considered "massive retaliation" as policy in future war. Hanson W. Baldwin of the New York Times informed readers that because there was little differentiation between nuclear and conventional weapons military thinkers believed there was not a moral difference between them either. In was their goal was "military victory as quickly and as cheaply as possible." ${ }^{48}$ The relationship of new weapons to American supremacy was apparent in advertisements placed in popular news magazines.

Companies associated with the Military-Industrial-Complex were selling their brand names in connection with technological innovation, security, civil defense, and patriotism. These advertisements portrayed a free and safe America. Public support for these companies, it was implied, would not only uphold democracy in a perilous world, but was also a patriotic duty. Convair and Chrysler associated themselves with a safe America. "Freedom has a new sound!" declared a Convair ad. A picture of three jet aircraft (presumably the F-102A manufactured by Convair) flying above an American town demonstrated its role in homeland security. The ad explained that new technology developed by Convair allowed for a "round the clock vigil" of the United States at supersonic speeds. "The next time jets thunder overhead," readers were told to

${ }^{58}$ Hanson W. Baldwin, "Russia Can Be Beaten Without A-Bomb," U.S. News and World Report, January 14, 1955. This article was reprinted from the New York Times. 
"remember that the pilots who fly them are not willful disturbers of your peace; they are patriotic young Americans affirming your New Sound of Freedom!"59 In another advertisement, Convair associated itself with homeland security by encouraging Americans to volunteer for the Ground Observer Corps. ${ }^{60}$ It showed a woman and a man looking skyward, while another woman noted the plane type (not shown to the viewer) on a clipboard. Readers are warned that low participation may make their town be vulnerable to "possible enemy attack." To encourage participation, the G.O.C. was described as "both interesting and exciting! A few hours a week of your spare time will help keep your home and country safe." ${ }^{, 61}$ A Chrysler advertisement emphasized its contribution to civil defense with its air raid sirens. They could be "operated automatically" or by "remote-control," and had a wail that carried up to "four miles in every direction. ${ }^{, 62}$ Both companies connected patriotism and security with images and language easily recognizable to sell their products and brand their names.

59 "Freedom Has A New Sound!" Convair Ad, U.S. News and World Report, July 15, 1955 , p. 129. When Americans were asked which branch of the armed forces would be most important in another world war seventy-one percent answered the Air Force. George H. Gallup, The Gallup Poll, vol. 2 (New York, 1998), p. 1321.

${ }^{60} \mathrm{GOC}$ was organized by the Air Force and consisted of civilian volunteers to "cover the 'blind spot' [of radar] to detect low-flying planes." On July 14, 1952, it was christened Operation Skywatch, but like other civil defense organizations, it lacked sufficient volunteers. This subject will be addressed more thoroughly in a later chapter. "The Skywatch. . . Needs 350,000 Volunteers to Keep the Air Safe," Newsweek, August 11, 1952, pp. 30-31.

61 "Another town is safe tonight ..." Convair Ad, Time, December 28, 1955. The Ground Observer Corps was continually under staffed. The primary reason for this was boredom.

62 “...15 Chrysler Sirens,” Chrysler Ad, U.S. News and World Report, April 17, 1953, p. 11. Italics in original advertisement. 
Advertisements also focused on the expanding role of "invisible" protection such as radar. Douglas Aircraft, a primary contractor with the Defense Department, connected its brand to the Air Force with a product that was often talked about but unseen: the Distant Early Warning System (DEW). Protecting America from sneak attack, Douglas told potential customers that the "DEW line depends" on their product, the C-124 Globemaster. ${ }^{63}$ The advertisement's focus illustration is a man running with a satchel under his arm. In the background was the Douglas built plane and another incoming aircraft. Another advertisement was more dramatic and covering two pages. Unlike the earlier ad, Douglas visually depicted what had thus been unseen: the radar of the DEW line, which appeared like an aurora borealis above the North Pole. Douglas informed readers that to prevent another Pearl Harbor, "fighter planes streak out in a matter of minutes, armed with rockets like the Air Force Genie-a Douglas built missile which can down an entire bomber with one blast. . . . It is no accident that we are now ready for attack from across the North Pole." ${ }^{64}$ These advertisements tied national defense, patriotism, and security with the Douglas brand name. Companies linking their brand with national defense encouraged customers to buy their products, and therefore do their part for supporting homeland security. As technology advanced and missile systems were

\footnotetext{
63 "Rush service to the top of the world!" Douglas ad, Time, April 9, 1956, p. 76.

64 "The threat . . mass bomber attack across the North Pole," Douglas ad, U.S. News and World Report, October 17, 1958, pp. 108-109. The ad also mentions the Nike Ajax and Hercules and the important role of all military branches.
} 
developed weapons shifted from a defensive to an offensive posture, and so too did company advertisements.

A Stromberg-Carlson advertisement demonstrated this change. It showed a group of men charting course with radar in what first appeared to be a defensive situation. The language of the ad, however, assures Americans that Stromberg-Carlson products allowed for instantaneously retaliation if a threat was apparent. The company's developments, readers were told, allowed for the "mere flip of switches . . to see what's ahead, identify its character, distance, and speed, and if necessary, alert the entire company through the intercommunication system and bring full fighting power to life." ${ }^{, 65}$ New technologies required faster response and as missiles entered Cold War arsenals, reaction time needed to be instantaneous.

The connection between missile development, changing civil defense procedures, and the transformation of public awareness and attitudes toward civil defense were also evident in apocalyptic novels written during the early years of the Cold War. There is a clear evolution in apocalyptic fiction: from a firm belief in civil defense to a call for disarmament. One novel that clearly supported civil defense was Tomorrow! written in 1954 by Philip Wylie. ${ }^{66}$ Set in American twin cities divided by a river, one side avidly practices civil defense and the other does not take it seriously. When enemy missiles hit

65 "Friend of Foe? How many? How far? How fast?" Stromberg-Carlson Ad, Newsweek, April 12, 1954, p. 55. Italics in original advertisement.

${ }^{66}$ Wylie changed his convictions over this same period and his changed views are reflected in his work. 
the twin cities, one obviously faired better than the other. ${ }^{67}$ Wylie's descriptions of the carnage and chaos resulting from lack of preparation were gruesome and unusual for the day (his descriptions can be compared to Steven King). Val Peterson, a firm supporter of graphic language concerning civil defense, hailed the book noting it was "shocking" and "ranked among [Wylie's] best." The Chicago Sunday Tribune agreed: "[the] terrifying novel could do more to save American lives in the event of atomic war then all the speeches that could be delivered by sincere and farseeing men between now and the time the first guided missile is launched by the enemy., ${ }^{, 68}$ The message of the book was clear: civil defense was possible, it would save lives, and cooperation would aid in post-war reconstruction.

Alas, Babylon was also about American life pre- and post nuclear attack. Like On the Beach, readers are immediately familiar with the main characters-perhaps because the setting is "small town" America. But unlike Nevil Shute, Pat Frank describes the submarine launched missile explosions, radiation poisoning, bandit wars, and the struggle for everyday survival without twentieth-century conveniences. ${ }^{69}$ As one critic remarked, "If Nevil Shute alarmed readers with 'On the Beach' Pat Frank will really frighten them with 'Alas, Babylon ..."70 Unlike Tomorrow! the story is not shockingly gory, but what

${ }^{67}$ Philip Wylie, Tomorrow! (New York, 1954).

${ }^{68}$ The Book Review Digest. March 1954 to February 1955 Inclusive (New York, 1955). pp. 977-978.

${ }^{69}$ Pat Frank, Alas, Babylon, (New York, 1959).

${ }^{70}$ Saturday Review, June 13, 1959, p. 20. 
is frightening is the rapid aerial assault on the United States by missiles with megaton nuclear warheads. As the main characters look off their rooftop after a nearby explosion to try to determine what city disappeared, another explosion occurs and than another. In Florida alone, Jacksonville, Tampa/ St. Petersburg, Orlando, Miami, and Homestead Air Force Base were targets. The bombing of these cities made the entire state of Florida a quarantine zone.

Frank's descriptions of civil defense preparedness-or lack there of - was very realistic. Randy (the hero), forewarned about the war by his Strategic Air Command (SAC) brother, tried to collect necessities for himself and his brother's family to survive. He did not have-nor did he read-any civil defense booklets, and therefore made several mistakes: he bought perishables (such as milk and meat), neglected batteries, flashlights, and matches, and was not prepared to live without electricity and plumbing. Randy was familiar with CONLRAD, however, and continued to resort to it for information from the "outside." Unlike On the Beach, the book ends on a happy note: the United States won the war, within a year SAC was patrolling remaining towns and cities and spreading hope, and Randy saves and protects his town. Alas, Babylon was well received and given overwhelmingly positive reviews. The Saturday Review wrote of the book's reality and commented that it sent "a small, fearful chill along our backbone." Linus Pauling, a Nobel Prize winning chemist and member of SANE, wrote that its only flaw was "the nuclear attack on the United States that is depicted represents in my 
opinion an understatement. . ."71 Both Tomorrow! and Alas, Babylon attempted to demonstrate the importance of basic civil defense preparation and reflected the belief that being well informed will pay off in time of nuclear war.

Two other novels focus on the role of shelters in the nuclear age; however, they do not have a happy ending. In fact, Level 7, by Mordecai Roshwald, is about the demise of civilization regardless of careful preparation and available shelters. Written in diary form, the book describes automated war and the government's proactive response to such a war. Five hundred specialists are chosen to survive thermonuclear war in a shelter located on the seventh level, or 4400 feet below the surface. It is sealed airtight and made self-sufficient for half a century. Each additional level holds people appropriate for its level (shelters get shallower as its occupants get less important and more numerous) and has a corresponding life expectancy: Level 6 holds the defensive command of 2000 people and is 3000 feet deep; Levels 5, 4, and 3, hold 20,000 civilians of different elite status (lower status denotes less protection) for 200 years; Levels 2 and 1 are for the rest of the population, the difference being that Level 2 is assigned and Level one is a freefor-all with minimum protection. Roshwald implies that Levels 2 and 1 were built to placate the masses rather than to provide adequate protection. After the war was fought, each level begins to get radiation poisoning that slowly seeped down to the selfcontained, hermetically sealed levels. Eventually it reaches Level 7 and everyone is

\footnotetext{
${ }^{71}$ The Book Review Digest. March 1958 to February 1959 Inclusive (New York, 1959). p. 376.

Pauling was a leader in the test ban movement. He circulated a petition among scientists calling for an "international agreement to halt nuclear testing as soon as possible" which was publicized in the press and sent to the White House. Robert A. Divine, Blowing on the Wind: The Nuclear Test Ban Debate, 1954-1960 (New York, 1978), pp. 125-127.
} 
killed. Ironically, the radiation poisoning came from a leak in the atomic generators meant to preserve life on each level-perhaps arguing that even atomic energy used for non-military purposes can be deadly. ${ }^{72}$

This book marks a clear demarcation from previous works of apocalyptic fiction. Like On the Beach, the world ends, but unlike Nevil Shute's novel, it portrays a prepared, and at least to some extent, a protected society. The book encompasses the present day fears of push-button war and technological advancements in weaponry. One reviewer declared that Level 7 made On the Beach "look like giddy optimism." Most reviewers, including New York Herald Tribune and New York Times Book Review interpreted the novel to be a warning. Another noted that reading it "promotes anxiety."73 This novel was reviewed by almost every major publication and it generated obvious discomfort to those that read it.

Triumph, also written by Wylie and published in 1963, reveals his changed perception of the effectiveness of civil defense. In the book, an unannounced nuclear attack throws an unexpected group of people together in a private shelter. Although the shelter has everything that one could possibly want, its occupants experience a series of unexpected and horrific events. Broadcasts from South America showed what had actually happened to the outside world after the war had ended: the mass panic, carnage, and destruction caused by nuclear war. Eventually, the inhabitants of the shelter are rescued, but the entire northern hemisphere is destroyed. Although this particular private

\footnotetext{
${ }^{72}$ Mordecai Roshwald, Level 7 (New York, 1959).

${ }^{73}$ The Book Review Digest. March 1960 to February 1961 Inclusive (New York, 1961). pp. 1141-1142.
} 
shelter worked, Wylie made clear that public shelters would not be successful in nuclear war: mass panic would kill those trying to get to them, and those that succeeded would over occupy them. His message is clear: preparation would not guarantee survival nor make nuclear war worth surviving. ${ }^{74}$ As one reviewer noted, Triumph is "a scare book, calculated to make people think about the consequences of a thermonuclear war and, presumably, to make them do something to prevent it." ${ }^{.75}$ The descriptions of the struggles to occupy public shelters, the desperate attempts to flee cities, and the mutilated dead and disfigured survivors were quite graphic.

These novels show the transformation of the American belief in civil defense by paralleling public concerns about protection and increasingly destructive weapons. In the early 1950 s, there was a firm belief that self-help would not only be practical, affordable, and necessary, but also desirable. There was not a fear of living in the world that would remain. As apocalyptic fiction began to be popularized, Americans were eager for information concerning civil defense. But as more information was released about new "instantaneous" "push-button" weapons capable of carrying megaton warheads able to demolish cities and as apocalyptic fiction reflected the folly of man-indeed the end of civilization-many began to doubt their prior convictions. This doubt and confusion brought shelters again to the forefront of civil defense discussions.

The feasibility of shelters began to be disputed once more but this time within the context of active versus passive defense. Proponents for shelters believed that creating an

\footnotetext{
${ }^{74}$ Philip Wylie, Triumph, (New York, 1963).

${ }^{75}$ The Book Review Digest. March 1963 to February 1964 Inclusive (New York, 1964). p. 1100 .
} 
effective shelter program would act as a deterrent against Soviet aggression. If the United States was prepared and able to save the majority of its population after a first strike, the retaliatory strike would be deadly, making an initial attack unlikely. Opponents of shelter construction held two views of the futility of a federally funded shelter program. First, living underground (or preparing to do so) would go against the fundamental principals of a free and democratic United States. Secondly, initiating a national shelter program would convince the Soviet Union that the United States was preparing for nuclear war and would provoke them to attack the United States preemptively. Both sides of the debate, however, saw the shelter as pivotal in protecting the masses in thermonuclear war.

The renowned father of the hydrogen bomb, Edward Teller, was a strong proponent of the public shelter program. With intimate knowledge of thermonuclear weapons, he argued: "If we prepare ourselves that a terrible attack could hurt us but not destroy us, then such an attack I believe will never come." But Teller also believed that if war did come, it would be short and "will be measured in hours, possibly in fractions of hours. ${ }^{76}$ His reasoning, of course, was that new weapons were so horrendous that a truce would be called early. Rather than emphasizing the urgency of shelter construction, Teller's argument highlighted the devastating effects of new weapons. As a result, many of those who read Teller's article were not convinced by his reasoning. Readers of the Bulletin of Atomic Scientists accused the journal of shifting its argument from disarmament to "rationalizations of what are morally indefensible attitudes and activities

${ }^{76}$ Edward Teller, "The Nature of Nuclear Warfare," Bulletin of Atomic Scientists 13 (May 1957): 162-165. Italics by the author. 
on the part of top government officials." A reader called for the "voices of American mothers" to be heard. ${ }^{77}$ Another argued that she "would rather parish in an atomic war than try to help rebuild civilization out of two-years-worth of goods stored away somewhere." 78 Americans feared the sophistication of new weapons and their threatened use created a sense of hopelessness concerning survival.

Even those that did not support a shelter program believed that civil defense demonstrated fear. Many opponents of shelters believed that their construction would create a false sense of security-or a "Maginot Line." 79 An article condensed from Harper's Magazine and printed in The Reader's Digest mocked civilian defense as militarization and criticized the inability of the federal government to protect its own citizens.

Every inheritance, possession, and investment; every business activity and expansion in a competitive society; every personal exercise of liberty and the pursuit of happiness-all those would be revolutionized if we adopted an urban decentralization and dispersal philosophy, a shelter psychology, and a conviction that we are living only on borrowed time. Why not go all the way? Let's draw up new laws, codes and a constitution to organize the good rabbit-and-mole life of the future. No Russian commissar, no Communist planner ever dreamed up anything so distasteful to individual freedom and so destructive to democracy....

${ }^{77}$ Evelyn Alloy, "Letters to the Editor," Bulletin of Atomic Scientists 13 (July 1957): 232.

${ }^{78}$ Laura Fermi, "Letters to the Editor," Bulletin of Atomic Scientists 13 (July 1957): 232. This reader was the wife of atomic scientist Enrico Fermi (who with Albert Einstein wrote a letter to President Roosevelt to encourage the building of the atomic bomb. Fermi, however, was against the development of the hydrogen bomb).

${ }^{79}$ Herman Khan dissected each anti-civil defense argument and commented, "It is curios that those who are most pessimistic in their estimate of the probability and consequences of nuclear war are generally to be found among the opponents of civil defense." Herman Khan, Thinking About the Unthinkable, (New York, 1962), p. 97. 
The sane people of this country will not take seriously enough to support an endless and fantastic national underground escapist program, costing between 20 and 30 billion dollars.

The problem of working out a well-balanced, modest, experimental, multi-purpose civil defense shelter program should be up to the established Department of Defense, which is suppose to protect us against attack and launch their counteroffensive. ${ }^{80}$

Herman Khan of the RAND echoed the belief that the Department of Defense should be protecting its citizens in his much talked about book On Thermonuclear War. He wrote, "it was not the purpose of people and property to fight a war; it is the purpose of the military to protect people and their property." response in dealing with international relations, but he felt that there was real danger in a disarmament policy. The possibility of "clandestine caches" would enable one power to always be ahead of others in the case of rapid rearmament. Kahn, however, was a proponent of civil defense and his controversial book argues if the proper precautions are taken - a combination of civil defense, finite defense (flexible response), and adequate air defense-not only is nuclear war survivable, but a relatively speedy recovery would also be possible. ${ }^{82}$

${ }^{80}$ Robert Moses, "Civil Defense Fiasco," The Reader's Digest 71 (December 1957): 5963. Laura McEnany argues that the United States government militarized everyday life by establishing a "permanent military presence in the civilian domain" by privatizing and individualizing civilian defense. Laura McEnaney, Civil Defense Begins at Home: Militarization Meets Everyday Life in the Fifties (Princeton, 2000), p. 5.

${ }^{81}$ Herman Khan, On Thermonuclear War (Princeton, 1960), p. 116. His perceived blasé evaluation of the human death rate in such a war often overshadowed his strong stance on a government sponsored shelter program and general preparedness education.

${ }^{82}$ Recovery would be relative to the rate of destruction, but Khan argued that, even so, recovery would be faster and more thorough than many have estimated. Ibid., p. 5. Kahn had been arguing for a national shelter program for at least one year prior to the release of 
Kahn's line of reasoning was counter to many who believed an effective civil defense would actually jeopardize the uneasy peace between the United States and the Soviet Union. James W. Deer, a volunteer radiological Defense Coordinator in Portland, Oregon, wrote, "a move toward shelter by one side is viewed with alarm by the other side." Federal Civil Defense Administrator Val Peterson agreed and gave this example:

Such information that we have out of Russia would indicate that they are doing a much better job than we are in dispersing industry and going underground. If they put a reasonable percentage of their war potential underground and provide facilities for their people to go underground at the edges of their cities and there is some indication that this is going on, as in the case of Europe generally, than it would appear that they have laid the foundation to minimize the effects of our retaliation in considerable degree. ${ }^{83}$

In fact, the Soviet Union did have a national civil defense plan, and they had active civil defense procedures since the Second World War. The exact extent of their planning and training was a matter of dispute at the time- - usually depending whether the point of view was for or against shelter construction. RAND member Leon Gouré wrote a controversial report about a "massive" Soviet "civil defense effort" in 1961 (later proved to be accurate), which demonstrated that the Soviet Union was preparing for nuclear war

OTW, however, his argument was not as graphic and therefore may not have attracted as much attention. "How Many can be Save?" Bulletin of Atomic Scientists 15 (January 1957): 30-34.

83 James W. Deer, "The Unavoidable International Shelter Race," Bulletin of Atomic Scientists 16 (February 1957): 66-67. Val Peterson quoted in Ibid., p. 67. This theme was used in Philip Wylie's Triumph. The Soviet Union was secretly building nuclear arms and stocking shelters large enough to protect their non-expendable population-all in violation of a treaty it had with the United States. Because of this, the Soviet Union was able to attack and shelter its populace during the U.S. retaliation. After waiting an acceptable time, the Russians came out of their shelters and delivered a counterretaliation on the United States-completely destroying the country. 
and training its population with mandatory classes. ${ }^{84}$ Indeed, the Soviet Union was well versed in civil defense against atomic attack and was also informed about American missile technology. The 1958 Soviet book Atomic Weapons and Anti-atomic Defense was written for the general public and contained comprehensive information about atomic weapons-how they worked and their effects--detailed information about missiles in the arsenal of the United States, and civil defense preparedness. ${ }^{85}$ While the Soviet government was indoctrinating its citizens about the consequences of nuclear weapons and how to collectively prepare for catastrophe, Americans were trying to predict Soviet reaction to a national shelter program and federal civil defense initiatives.

The effect that missiles would have on American civilian defense was immense and was noted by several committees who reported directly to Congress and the President. A civil defense study conducted by RAND recommended building shelters as a primary means of protection; The Gaither Report recommended a multi-billion dollar shelter program to protect from blast as well as fallout; The Rockefeller Report called for a national fallout shelter program. ${ }^{86}$ In the same year, the Soviet Union launched the first

84 "Communists: They Have Shelters too," Time, March 30, 1962, pp. 21-22. By 1962, Gouré had published a book on Soviet civil defense. Leon Gouré, Civil Defense in the Soviet Union, (Berkeley, 1962). In 1970 a translation of a Soviet text on civil defense was published in the United States, which underscored the value of Gouré's research. P.T. Yegorov, I.A. Shlyakhov, and N.I. Alabin, Civil Defense: A Soviet View, rev. (Washington, D.C., 1970).

${ }^{85}$ M. Gvozdev and V. Iakovin, Atomnoe oruzhie i protivo atomnaia zashchita (Atomic Weapons and Anti-Atomic Defense) (Moscow, 1958). This Soviet book gave more detailed information than American publications during the same time period.

${ }^{86}$ The Gaither Report was kept from Congress and only presented to President Eisenhower (it was considered a National Security Council document), who dismissed it. 
intercontinental ballistic missile and shortly after underscored their technological superiority with Sputnik, the first artificial satellite.

A year later, Chet Holifield in an interview with Ralph Lapp, emphasized the importance of shelters in the missile age. Americans have to prepare for the worst, he warned, because "lethal effects of high yield weapons can be magnified" making them the Russian "weapon of choice." In addition, there was "the matter of ICBM's 'missing' their targets with blast damage but still 'hitting' with fall-out." Like Khan, Holifield told Americans that good civil defense was a war deterrent: it would demonstrate to the Russians that the United States was capable of surviving an attack and would be able to massively retaliate. ${ }^{87}$ It was precisely at this time, however, that there was an evident decrease in information about civil defense. Popular magazines began to shift their emphasis to missile development, the "missile gap," and the Space Race.

In response to new missile technology, James Deer declared that in 1958 civil defense was dead. Deer's timeline correlated with predictions of the effect that the missile would have in future wars and was also reflected in best-selling apocalyptic fiction of the same year. The reason for this, he argued, was pre-1958 civil defense

Kenneth D. Rose, One Nation Underground: The Fallout Shelter in American Culture, (New York, 2001), p. 32. The Rockefeller Report insisted that " in the age of [the] ballistic missile' a society's ability to withstand attack 'will become and increasingly important deterrent."' Ibid., p. 29-30. All of these studies were presented in 1957. Within two years of the Rockefeller Report, New York City's governor, Nelson A. Rockefeller "launched a campaign to make New York the first state in the nation with compulsory nuclear shelters for its citizens. "For New Yorkers: Compulsory Shelters," Newsweek, July 20, 1959, p. 24.

87 Ralph E. Lapp, "Civil Defense Shelters: An Interview with Congressman Chet Holifield," Bulletin of Atomic Scientists 14 (April 1958): 130-134. 
presumed that "the country was expected to come out of a war with essentially the same structure as it went in." In the thermonuclear missile age, however, "this idea has now clearly been abandoned." Most Americans he had talked with "already assume that, in the event of an all-out nuclear war, all human life would be wiped out from the face of the globe." 88

Americans were contemplating fact, fiction, and the hypothetical, as submarine launched ballistic missiles and ICBMs became a reality. These weapons increased weapon range, targeting ability, and warhead capacity. Even though shelters were propagated as a necessary means for surviving a nuclear war, Congress did not appropriate funds or provide tax breaks for their construction. Instead, more money was designated for the nuclear arsenal. It was government policy that "every surviving American family should be prepared to feed and protect itself without help for two weeks after a nuclear attack." ${ }^{89}$ Instead of providing underground shelter, Congress continued to contribute to a nuclear shield. At the same time, headlines predicted war, questioned national defense, and described the growing threat of the Soviet "menace." Americans could only try not to think about the "inevitable"-aiding to the outcry against Khan's candid discussion of the "unthinkable." 90

${ }^{88}$ James W. Deer, "Whatever Happened to Civil Defense?" Bulletin of Atomic Scientists 15 (June 1959): 266-267.

89 “Old Subject Reopened: Survival,” Life July 20, 1959, p. 30.

90 This lack of participation and information about civil defense is apparent in the Gallup Polls. When Americans were asked how they felt about the way civil defense was handled in their local area fifty-nine percent had little or no knowledge about their local defense plan. George H. Gallup, The Gallup Poll, vol. 3, p. 1724-1725. 
The changing nature of weapons technology from aerial "atomic Pearl Harbor" to an almost instantaneous missile launched thermonuclear war resulted in gradual shifts in both civilian defense and public opinion about the effectiveness of civil defense. The policies of the Federal Civil Defense Administration could not keep pace with weapons technology. The public appeared to be apathetic, but polls show Americans wanted to be better informed. As weapons became more powerful and accurate, and preparation time decreased to only thirty minutes, Americans increasingly felt increasingly hopeless. 


\section{Chapter 4}

\section{Defender of American Cities:}

\section{The Nike Missile System in San Francisco}

Missiles are what will actually stop an atomic attack [on American cities]. It is these weapons, whether launched from an aircraft or from the ground, that give the real promise of success where only hopelessness had existed before. $^{1}$

The first guided defensive missile system in the world to be developed and deployed was the United States Army's Nike missile system. It was built before the threat of intercontinental ballistic missiles and was designed to protect major target cities from attack by Soviet jet bombers. The city of San Francisco, California, found itself surrounded by the new defensive missiles as the Cold War intensified. Because of their proximity to the Soviet Union, the Pacific proving grounds, and the Nevada Test Site, Bay Area citizens understandably felt vulnerable to attack. The Nike missile system incorporated a ring of protective missiles around a defense area, and it also included a vast network of computers and radars that eventually stretched from Hawaii to the Azores. The previous three chapters demonstrated the intangible fears experienced by Americans as a result of missile technology and development. Government secrecy, fears of accidental war, and civil defense challenges are brought together with defensive missile technology changing the landscape of San Francisco.

San Francisco is over three hundred miles away from NTS, but citizens of the city were very aware of nuclear testing taking place there. Tests made front-page news in the

1 "Atom Bomb Can be Stopped: Secret Weapons Cut Threat to Cities," U.S. News and World Report, January 8, 1954, pp. 19-23. 
local newspapers and many were able to see and feel the explosions. ${ }^{2}$ As soon as the tests began, Bay Area newspapers kept residents informed as American scientists began "tickling the dragons tale." 3 Seismologists at CalTech (California Institute of Technology) - over three hundred miles away from NTS-recorded the blasts. San Francisco residents found them to be nuisances. But in a culture used to earthquakes, feelings of annoyance gradually changed to acceptance. ${ }^{4}$ As the polarization of the world between the United States and the Soviet Union became more evident, the public reaction to domestic atomic testing soon changed to reflect fears of nuclear war and uncertainties of the future.

Only a month after the domestic bomb project began, the press began speculating about test results. Secrecy pervaded these early nuclear tests, with little, if any

${ }^{2}$ By the forth test in the first series of detonations at NTS, it was reported, "The burst of white light was seen as far south as San Diego 360 miles away and in Los Angeles and Pasadena." Clint Mosher, "4 ${ }^{\text {th }}$ A-Bomb Test Jars Nevada: Great Flash Lights Sky," San Francisco Examiner, February 2, 1951, p. 1. In May 1952, readers were told, that the flash was so brilliant that it momentarily blinded observers "more than 45 miles away. The flash was seen more than 400 miles away, in Los Angeles, despite a high cloud cover. It lit up the sky "almost like day." "New Atomic Flash seen 400 Miles," San Francisco News, May 5, 1952, p. 6.

3 "3rd Atomic Blast Jolts Nevada Like Thunder at Dawn," San Francisco Chronicle, January 29, 1951, p. 1. This term was used by Atomic Energy Commission (AEC) physicists in reference to "their trick of producing low yield nuclear fission bursts-a small puff of explosion that was hardly an explosion." In reference to the tests used in development of the atomic bomb during the Manhattan Project-code name "dragon"and keeping in mind the "prowess" of the fictional animal, AEC physicists began to refer to early atomic experiments as "tickling the dragon's tail." Ibid.

${ }^{4}$ Gladwin Hill, "Nevada Atomic Blast No. 3-But By Now Las Vegas is Blasé," San Francisco Chronicle, February 2, 1951, p. 4. Although residents of Nevada were described as blasé, Hill was obviously shaken by the demonstration. He declared it "gave one a strange feeling of fleeting contact with eternal powers.... [which resulted in an] eerie hypnotic silence." 
information released to the public. This resulted in reporter speculation about their significance. The first set of tests led to the conclusion that the United States had perfected an atomic bomb small and light enough to fit artillery rocket launchers. ${ }^{5}$ The fear of nuclear holocaust was further re-enforced when Army troops began to drill for combat within the vicinity of atomic explosions. In 1951, the San Francisco News told readers, "that it is now known that troops can follow up immediately over an area destroyed by an atomic weapon and that civilian defense can get under way within minutes after an atomic attack on a city." that nuclear war was near. Such speculation demonstrated the connection that was made between the importance of nuclear development and future war. This would also lead many to conclude that similar developments were being made by the Soviet Union. Therefore, weapons like those being tested in Nevada could possibly be used against Americans.

This correlation of hypotheses created a real fear in nearby residents. In San Francisco, this fear was apparent in local newspaper articles. Atomic tests at the NTS

${ }^{5}$ Clint Mosher, "New Type of Atom Bomb Fired: Shock Wave Jolts Area," San Francisco Examiner, February 3, 1951, p. 1.

6 "'Troops Can Follow Up In Atom-Blasted Areas: No Immediate After Effects,' Witness Says, San Francisco News, May 12, 1951, p. 1. Four years later, it was reported that Army tank divisions were training with atomic weapons. The San Francisco Examiner described the terrifying tests: "The atomic detonation subjected the rugged tanks to a flash hundreds of times as bright as normal daylight, a shock that rattled the earth to its depths and produced heat so intense the air around the atomic fireball literally burst into flames." The blast of the explosion was so strong that it felt "like an earthquake" and as if the tank were in a "rough sea." The war game was lost by the enemy, but there must have been little relief felt by readers concerning the strength of the attack - with weapons they already learned were outdated. Julian Hartt, "Eyewitness With Tank Tells of Blast 'Attack,"' San Francisco Examiner, May 6, 1955, p. 4. 
were practically considered local news in surrounding states, and in San Francisco, the blasts made front-page headlines regularly during the 1950s. The city may have been over three hundred miles away, but San Franciscans and the surrounding area experienced the atomic explosions first hand. Although the NTS was tucked away within a valley surrounded by mountains, the flash of blinding light, its deafening roar, and the powerful after shock of the bombs were a constant reminder to Americans of what the next war would bring.

Like residents of other cities, San Franciscans prepared for civilian defense measures instituted by the Truman administration. ${ }^{7}$ Like other cities around the country, concern for civilian protection was already apparent in San Francisco before the formation of the FCDA. Local newspapers and city planners hypothesized about war scenarios. On January 2, 1951 the San Francisco Chronicle provided its sober assessment of a post-atomic attack landscape: no electricity, dried up reserves, transportation ground to a halt, and an estimated 212,940 people dead, another 162,283 injured. Like much the information gathered for civilian defense, the estimates of this article came from extrapolations of the already outdated casualty reports of Hiroshima and Nagasaki, which revealed how optimistic and conservative they were. ${ }^{8}$ The next day, readers were warned

\footnotetext{
${ }^{7}$ The cover of Time magazine underscored this belief only one year before testing began at NTS. On it is retired General Lucius Clay, an atomic mushroom cloud and a city skyline. Time, October 2, 1950, cover.

8 Jack Foisie, "What Would Happen if A-Bomb Fell Here?-City Survey," San Francisco Chronicle, January 2, 1951, p. 5.
} 
that the state's primary concern was "how to survive should war strike." California

Governor Earl Warren warned the state "faces the greatest crisis in its history." The next war would be total: Americans were going to be attacked "right here in our cities." 10 The means of waging war would extend beyond conventional and atomic weapons. Gas and biological warfare were "just as chilling as an atomic attack," and everyone was advised to practice bomb drills. ${ }^{\text {II }}$ The president of the California League of Cities continued the alarm when he announced, "that our state and our nation are in serious threat of attack." 12 Within days, the city of San Francisco told residents it was doing all it could to obtain air

${ }^{9}$ Mary Ellen Leary, "State Politics Centers on War Survival," San Francisco News, January 3, 1951, p. 2; Lloyd Lapham, "Civil Defense No. 1 'Must' This Season," San Francisco News, January 8, 1951, p. 2; Earl C. Behrens, "State Legislature: Civil Defense to be Stressed by Governor," San Francisco Chronicle, January 8, 1951, p. 1.

10 "If War Comes We're It First, Warren Warns: Up to California, Defense Parley Told," San Francisco News, January 4, 1951, p. 9. The governor also said that the state was going to go "all out" for civil defense. As a result of this decision, all households of San Francisco were being mailed (free from the state) 240,000 copies of Survival Under Atomic Attack. "A-Bomb Booklets to be Mailed in S.F. Next Week," San Francisco News, January 4, 1951, p. 9; "Civilian Defense Activities: All City Families to Get Atom Pamphlet," San Francisco Chronicle, January 10, 1951, p. 10.

11 James Daniel, "How to Be Your Own Civil Defense Expert," San Francisco News, January 3, 1951, p. 2. Readers were advised that children should not find such drills more alarming than the already circulating adult rumors and were told that if such drills were "carried out efficiently and cheerfully, they could assure calmness in real trouble." Ibid. The booklet's information concerning biological and chemical warfare, however, was sanitized: "You encounter here and there, remarks to the effect that detailed information about chemical and germ warfare is too grim for the American people to take and that it would be better for their moral to ignore it, for fear that an informed public would become a hysterical public. It seems to us that the likelihood is just the other way about: the best way to avoid hysteria is by preparing in advanced against all that can happen." Editorial. San Francisco Chronicle, January 10, 1951, p. 18.

${ }^{12}$ Earl C. Behrens, "Civilian Defense: Warren Urges Intensive City Organization," San Francisco Chronicle, January 5, 1951, p. 1. 
raid sirens and was gathering information from colleges and doctors to prepare for such a disaster. ${ }^{13}$ Soon San Francisco was leading the civil defense effort in the state of California. $^{14}$

The perceived vulnerability of San Francisco combined with reports about atomic bombs underscored the belief that shelters would be the only viable means of protection in event of an attack. This reality, however, did little to convince the government that a shelter program should be funded. ${ }^{15}$ Local planners prepared for the worst by supporting limited evacuation and identification tags for children. Parents, though cautioned against panic, were encouraged to prepare to send children to relatives or friends living outside of the Bay Area in case of attack. School children were given dog tags so their bodies could

13 "No Alerts Pending Louder Sirens," San Francisco Chronicle, January 4, 1951, p. 3; "City Speeds Deal to Get Sirens: First Bids Called," San Francisco News, January 4, 1951, p. 13; "Schools for Defense: U.S. Queries Local Colleges on Facilities for War Training," San Francisco Chronicle, January 8, 1951, p. 1; "Doctors Given Disaster Day Assignments," San Francisco Chronicle, January 11, 1951, p. 10. Readers were also told that San Quentin prison was to be readied as a hospital in such an attack. "Prison to Aid Civil Defense: Man Power and Facilities at San Quentin Readied," San Francisco Examiner, January 18, 1951, p. 7.

14 "S.F. Leads in California's Civil Defense, Says Hatfield," San Francisco Chronicle, February 3, 1951, p. 4.

15 Royce Brier, "This World Today: No Place to Hide but Shelters," Editorial, San Francisco Chronicle, January 3, 1951, p. 18; "Bomb Shelter in Every Back Yard Again Urged," San Francisco Chronicle, January 7, 1951, p. 12. The next day, twelve Oakland (a suburb of San Francisco) buildings were designated as bomb shelters. "Volunteers Needed for Civil Defense," San Francisco Chronicle, January 8, 1951, p. 4; "No S.F. Evacuation If A-Bombs Fall, Red Cross Agrees," San Francisco News, January 10, 1951, p. 16; "Raid Shelters for Public Use in S.F. Studied," San Francisco Examiner, January 17, 1951, p. 10."U.S. to Limit Funds for Bomb Shelters: No Aid to be Given Outside of Target Areas," San Francisco Chronicle, February 13, 1951, p. 5. 
be identified in the aftermath of attack. In addition, children practiced air raid drills in the classroom. ${ }^{16}$

Tensions in the city were heightened as the relationship between the United States and the Soviet Union continued to deteriorate and the war in Korea raged on. San Franciscans prepared for the worst as they read about the increased military capability of the United States armed forces and Truman's call for "total control of prices and wages as part of the cost of rearming the nation." ${ }^{, 17}$ Heightened anxiety caused some to decry the democratic principles defended by America's involvement in the Cold War. One local Jesuit declared that it was "morally, ethically, legally, and militarily right" to preempt war with the Soviet Union with atomic bombs. ${ }^{18}$ Such headlines underscored the idea that the nation was preparing for nuclear war with the Soviet Union.

A San Francisco radio poll taken in early 1951 asked listeners what their primary concerns were and reported that about half of the 4600 respondents worried about war. When asked what they would like to see make headlines in local papers, about fifty percent wanted to read about "peace by mutual understanding without use of military

16 "How to Prevent A-Bomb Panic: First Aid Trailers Urged by Psychiatrist," Editorial, San Francisco News, January 17, 1951, p. 14; Nan White, "Exchange of Dog Tags Among Teens has School Authorities in Dither," San Francisco News, January 12, 1951, p. 16; Tim Adams, "San Bruno School Air Raid Test Is an Aching Success," San Francisco Chronicle, January 13, 1951, p. 1.

17 "Truman Sees Total Control: Full Wage, Price Curbs Predicted Soon by President." San Francisco Chronicle, January 5, 1951, p. 1; "New Army Tanks 'Far Superior," San Francisco Chronicle, January 5, 1951, p. 1; "Navy to Take Ships from Struck Yards," San Francisco Chronicle, January 5, 1951, p. 1.

18 "Father Walsh Says: It's Right that We Use the A-Bomb First: Diplomatic Authority Makes Strong Case for Not Waiting for Enemy to Attack Us," San Francisco News, January 5, 1951, p. 16. 
force." 19 This pessimistic view of the international situation was also revealed in a poll taken of Bay Area residents by the San Francisco Chronicle at the end of the year. Of those polled, only twenty-eight percent believed that the New Year would bring an "improving world." ${ }^{, 20}$ Rather than preparing for peace, however, military planners were preparing for attack.

To meet threats of another war military planners needed to restructure the American landscape: traditional borders needed to change. Although they were mentioned in Chapter 2, both radar and DEW need to be explained in conjunction with the Nike missile system to better understand how technology changed the American landscape. In response to recommendations made by Project East River-a study to aid the federal government to prepare American civilians for nuclear war-Policy Planning Staff members Paul H. Nitze and Carlton Savage suggested that the United States establish an early warning system. ${ }^{21}$ This would be the first step in a "program necessary for the United States against atomic attack," they argued. Such a system of national defense "would be a powerful deterrent to war [because] the enemy would be reluctant to

${ }^{19}$ Royce Brier, "This World Today: Worries People Have These Days," Editorial, San Francisco Chronicle, February 8, 1951, p. 18.

20 "San Franciscans See '52 Through Half-Rosy Glasses," San Francisco Chronicle, January 1, 1952, p. 1.

${ }^{21}$ Project East River lead to National Security Council (NSC) 139 which stated that because of the Soviet atomic threat, the United States should develop an "effective military and civil defense system ready no later than December 31, 1955," as well as a radar system "capable of providing a minimum of three hours warning." Memorandum by Paul H. Nitze and Carlton Savage of the Policy Planning Staff. Washington, May 6, 1953. Foreign Relations of the United States, 1952-1954, vol. II: National Security Policy: 318-3323. (Hereafter, FRUS). Project East River is also discussed in Chapter 2. 
strike if its blows would not be effective." An early warning system, it was argued, would allow both the Strategic Air Command (SAC) and the Army to have sufficient time to prepare defenses as well as give citizens time to seek shelter or evacuate target areas by giving an estimated three to six hours of warning time. ${ }^{22}$ The need for adequate warning was acutely felt in San Francisco, a major Soviet target city.

Largely in response to the Soviet detonation of an atomic bomb, the Department of Defense created a "series of interlocking radars to monitor the perimeter and selected portions of the continent" to gain between five and six hours of warning time in case of enemy bomber attack. Designated Lash-Up, the set of radar systems was initially created to protect major nuclear production centers and costal cities. The system grew from seven sites in 1949 to fifty by 1951. Within a year, however, Lash-Up was replaced by another system and was also augmented by the Pinetree Line. The Pinetree Line was a limited radar line consisting of thirty-four stations just north of the United States border with Canada. Completed in 1952, it only allowed for a drastically reduced two hours of warning because of the increased speed of aircraft.

Radar lines would become a key component in continental missile defense and would alter how Americans thought of their national borders. ${ }^{23}$ The Policy Planning Staff correctly predicted "[d]istant early warning will become increasingly important in the

22 Paper Drafted by Paul Nitze and Carlton Savage of the Policy Planning Staff, Washington, November 11, 1952, FRUS, 1952-1954, vol. II: National Security Policy: 182-184; Report to the National Security Council by the Acting Executive Secretary of the Council, December 31, 1952, FRUS, 1952-1954, vol. VI: Canada: 2063-2064.

23 Mark A. Berhow, U.S. Strategic and Defensive Missile Systems, 1950-2004, (University Park, Illinois, 2005), p. 10. Radar lines would also become outdated before they were fully functional. Weapons technology outpaced defenses. 
near future with the increasing speed of airplanes and the development of longer range guided missiles." 24 At the time missiles were considered weapons of the future; the immediate concern for the public was Soviet long-rang bombers capable of dropping atomic weapons on American cities. The arrival of long-range bombers-and eventually missiles-altered American's perception that they were shielded from air attack. To help close the gap of the current faulty radar system, the United States Air Force depended on voluntary participation from its citizens.

Accordingly, the Air Defense Command established the Ground Observer Corps (GOC). This voluntary organization maintained a twenty-four hour watch for "intruder planes" that might "sneak under the radar screen" with posts spaced approximately every eight miles along the Pacific Northwest. Mock drills by the Air Force "proved conclusively that low-flying planes could not be detected by radar and had to be spotted by ground observers." 25 To test the effectiveness of coastal defenses, "air wars" were conducted off the Pacific coast as early as 1951. Thirty-six thousand GOC volunteers in California, Oregon, and Washington participated in the four-day maneuver. ${ }^{26}$ Like much

${ }^{24}$ Memorandum by Paul H. Nitze and Carlton Savage of the Policy Planning Staff. Washington, May 6, 1953. FRUS, 1952-1954, vol. II: National Security Policy: 3183323.

25 "The Skywatch...Needs 350,000 Volunteers to Keep the Air Safe," Newsweek, August 11, 1952, pp. 30-31.

26 "Jet Fighters to Come Down for Low Level Maneuvers," San Francisco News, February 2, 1951, p. 9; Aerial War Games: Defense Reports Success Against Mock Bomb Raids," San Francisco Chronicle, February 3, 1951, p. 1; Jack Foisie, "The City Airplane Spotters Keep a Sharp Eye on the Sky," San Francisco Chronicle, February 4, 1951, p. 5. The GOC was designated Operation Skywatch on July 14, 1952. Sidney Shalett, "They Hope They're Wasting Their Time," Saturday Evening Post, September 26, 1953, pp. 40-41. 
defense information at the time, the outcome of the drill was classified and was not released to the public. But two announcements made it clear that the Pacific coast was still vulnerable to enemy air attack: after the drill, it was announced that more civilians were still needed to man the GOC posts, and while training had proven successful, defense of the area had not. ${ }^{27}$

Skywatchers were stationed in towers across the country, which were ideally manned twenty-four hours a day. Their job was to log each plane that was spotted while on duty and to report all jets and multi-engine planes to a filter center. "There, the plane is checked against scheduled flights" and if the flight was questioned, the plane was contacted by radio to be identified as friend or foe (IFF). If it was unable to be identified, the commanding officer of the Continental Air Defense Command (CONAD) in Colorado Springs was notified. Given the order, the "interceptor planes will be scrambled, the Red Alert will warn Civil Defense, and sirens in the threatened cities will wail." ${ }^{28}$ CONAD was building a "fence in the sky" around the United States that would eventually reach from the Arctic Circle to below the Rio Grand and from West Germany to Hawaii. In conjunction with the Canadian Air Defense, CONAD was structuring another radar line above the Pinetree Line called the Mid-Canada Line and by 1960, the Distant Early Warning (DEW) radar line would be completed. These radar lines were

27 "S.F. Air Defense: Four-Day 'Raid' Tests Wind Up; Public Won't be Told the Results," San Francisco Chronicle, February 5, 1951, p. 5.

28 “'Skywatch' Could Save S.F." San Francisco News, July 8, 1954, p. 1; Pamela Burr, "I Am a Sky Sentry," Saturday Evening Post, July 9, 1955, p. 30. 
made tangible by being visualized as a "net," "fence," or "shield" in the sky, altering the way Americans perceived their landscape to include the invisible. ${ }^{29}$

Perhaps the most ambitious technological initiative for national defense was the development of the computer and the radar based air defense system SAGE (Semiautomatic Ground Environment), which when operational would replace the human-dependant system. SAGE would calculate flight paths and interceptions, but humans would work with the system by computation. "[SAGE] linked the Air Force Air Defense Command, Tactical Air Command, and SAC as well as the Army's Air defense Command and Army Air Defense Command's (ARADCOM) Nike Missiles system. (Appendix A 4.1) ${ }^{, 30}$ SAGE was outdated before it became operational, but the project contributed to computer programming and the technological advancements in the new age of air defense. ${ }^{31}$ Together, jet bombers and radar warning systems provided a sense of

${ }^{29}$ The DEW line would reach from Alaska to Greenland, but eventually stretch from Hawaii to the Azores because of "picket planes"-or flying radar stations. In the North East of the United States, CONAD stationed radar stations called "Texas Towers" (they resemble oilrigs). "The Long Skywatch: Building a Tighter Defense Despite Peace Talks," Newsweek, July 18, 1955, p. 23; Berhow, pp. 10-11; Draft Statement of Policy Proposal by the National Security Council, February 11, 1954, FRUS, 1952-1954, Vol. II, Foreign Relations: 619; "Defense: The Supersonic Shield," Time, December 20, 1954, pp. 15-19.

${ }^{30}$ Berhow, p. 11. Incidentally, the complex SAGE system was touted as "pushbutton defense" by Life. "Pushbutton Defense for Air War," Life, February 11, 1957, pp. 62-66.

31 Thomas P. Hughes, Rescuing Prometheus: Four Monumental Projects that Changed the Modern World, (New York, 1998), Chapter 1. SAGE was never used, but it was not deemed a failure. After the SAGE experience, some of its engineers and scientists helped create the ARPANET, predecessor to the Internet. Hughes, pp. 66-67. SAGE was also outdated because its size was impractical: the computer network filled an entire fourstory building making it vulnerable to attack. It also consumed as much electricity as a town of 15,000 people. "So great was the wasted heat generated by its operation that it was sometimes used to heat the bases on which it sat." Stephen I. Schwartz, ed. Atomic 
security to Americans. New defenses were not longer "dream weapons of the distant future," but becoming a reality. ${ }^{32}$ Technology was quietly replacing the eyes and ears of civilian observers with more sophisticated radar and computer networks.

Before the development of the defensive Nike-Ajax missile system, the Army Antiaircraft Command (ARAACOM) defended American coastal cities with anti-aircraft artillery (AAA). The city of San Francisco had three such AAA gun units protecting the city, but new jet bombers flew too fast and too far out of range for defense weapons of World War II to be effective. ${ }^{33}$ Although still in place and manned through the early 1950s, AAAs were quietly being replaced by surface-to-air missiles (SAM). ${ }^{34}$ The Army began to develop two separate but related systems: the Nike missile and the M-33 integrated fire control system. ${ }^{35}$

The Nike missile-named after the winged Greek goddess of victory-began development in 1945. It was also the "first supersonic missile designed to follow and destroy the enemy target regardless of evasive action." 36 The first missile in the Nike

Audit: The Cost and the Consequences of U.S. Nuclear Weapons Since 1940, (Washington, D.C., 1998), p. 278.

32 "Atom Bomb Can be Stopped: Secret Weapons Cut Threat to Cities," U.S. News and World Report, January 8, 1954, pp. 19-23.

${ }^{33}$ Mark L. Morgan and Mark A. Berhow. Rings of Supersonic Steel: Air Defenses of the United States Army, 1950-1979, $2^{\text {nd }}$ ed. (San Pedro, California, 2002), p. 8.

${ }^{34}$ ARAACOM was renamed to Army Air Defense Command (ARADCOM) in 1957 because the term "antiaircraft" became obsolete when missiles also became targets.

${ }^{35}$ Ibid, p. 28.

36 "Nike-Ajax Fact Sheet," U.S. Army Ordnance Missile Command, Public Information Office, Undated, Kennedy Space Center Archives, Missiles, Box 30A.1, Folder 3. (Hereafter KSC). 
family was the Nike-Ajax (MIM-3). It consisted of two parts: "an expendable missile, and the ground-based launching and control equipment." In 1944, the Army contracted with Western Electric and Bell Telephone Laboratories (who in turn, worked with many subcontractors) "to develop a fully integrated radar/ computer antiaircraft fire control system," which resulted in the M-33 system. The M-33 system eventually consisted of several major components: "three radars, a computer, automatic plotting boards, remote control launching racks, and power generators." ${ }^{, 37}$ Reflecting the complexity of the missile system, the configuration of a typical Nike battery was also separated into two parts: the Integrated Fire Control (IFC) area and the Administration area (they were often coupled together, but were sometimes separated) and the magazine and launcher area. Operationally, most sites were identical but geography dictated variation. To understand the complexity of the Nike system, it is necessary to explain site design and the process of achieving missile readiness.

The Nike-Ajax was quite intricate and was not completely reliant on computers. The system was often perceived as the beginning of push-button technology, but the Nike relied on humans to operate. The average firing battery (two or three launch sections) consisted of one hundred men working in shifts to operate. Larger batteries required up to two hundred men. ${ }^{38}$ The launching area for the Nike-Ajax was gated and guarded by armed men. To enter, identification had to be checked at the sentry post. The magazines

${ }^{37}$ Ibid.

${ }^{38}$ John G. Lunn, LTC (Ret.) and former Nike Missileman, Interview by Jessica Barrella, San Francisco, California, July 14, 2006. 
were below ground and the missiles were manually loaded to a hydraulically operated elevator by manually pushing and pulling. Once above ground, they were manually pushed on the rails to their launchers. "We could get a missile up and ready to fire in 15 minutes from a dead sleep," recalled Ron Parshall, former Private, Nike Electronic Equipment Repairman and Launcher Crew. "A missile could be brought up and pushed over to the launcher, checked, connected, and able to fire in roughly 5 minutes." ${ }^{\text {"39 }}$ When ready, the Nikes were elevated to an angle of approximately 88 degrees and launched. ${ }^{40}$ To maintain readiness, each battery was on different levels of alert. There was at least one "hot" battery-depending on the number in the area. The "hot" battery had to be ready within one hour. There was a three-hour battery and a six-hour battery (maintenance). But men on duty always had to be ready to report for action within five minutes. $^{41}$

The missile launch facility was self-contained and capable of independent action. Most launch area configurations had two or three underground magazines, housing approximately ten to twelve Ajax missiles, each with an elevator to raise the missiles to the surface. "Each magazine had four aboveground elevating rails" for raising the missiles to launch position. ${ }^{42}$ Each rail was able to accommodate approximately four

${ }^{39}$ Ronald W. Parshall, Private, Nike Electronic Equipment Repairman and Launcher Crew, Interview by Jessica Barrella, San Francisco, California, July 14, 2006.

40 "Nike Missile Site SF-88," Pamphlet, Golden Gate National Parks Association, 1999.

${ }^{41}$ Ezio F. Nurisio, Spec. 5, Nike Target Tracking Radar Supervisor, Interview by Jessica Barrella, San Francisco, California, July 16, 2006.

${ }^{42}$ Berhow, p. 19. 
missiles. Once above ground, the missiles were separated on launch rails, with the last missile launched from the launcher located on the elevator. When all rails were armed and missiles were erect, it made for an imposing site. Getting the missiles into launch position was almost a completely manual operation.

The Integrated Fire Control and administration areas were located at least 1000 feet from the magazine and launch area. The IFC contained the "radars and radar equipment for acquiring and tracking the target and missile, the battery control assembly, the early warning plotting board, an event recorder, and a switchboard cabinet"-or essentially, the M-33 component of the Nike missile system. The missile itself was launched and operated in conjunction with various radar and computer tracking. The site had Acquisition Radar (ACQR) that spotted the incoming enemy aircraft and provided data to the Target Tracking Radar (TTR), which "locked on to the target." Simultaneously, the Missile Tracking Radar (MTR) locked in on the Nike before flight. Data from both the TTR and the MTR were fed to the electronic data processing equipment, which calculated the interception point. ${ }^{43}$ Although the press made the Nike missile appear to be a "push button" system, it was far from instantaneous.

The Nike-Ajax missile was a first generation guided missile and consisted of two stages. It was one foot four inches in diameter, twenty-one feet long, weighed approximately 2,445 pounds and had a flight range of twenty-five to thirty miles. It carried three high-explosive conventional warheads mounted in the nose, the center, and

${ }^{43}$ Morgan and Berhow, pp. 9-10. 
tail sections. ${ }^{44}$ Even these early missiles had built-in safety precautions: their warheads were detonated from orders received from the ground. The first stage of the Nike-Ajax had a solid-propellant booster, and the second stage was liquid-fueled. It had three sets of fins: the forward was for steerage, the middle had sensory equipment, and the rear provided stability. Douglas Aircraft manufactured the missiles in Santa Monica (and later at the Army Ordinance Missile Plant in Charlotte, North Carolina). "In total, Western Electric and Douglas Aircraft produced 358 ground batteries and nearly 14,000 NikeAjax missiles for the Army during the duration of the missile's deployment."45 The major flaw of this first generation system was that only one missile could be fired at a timealthough missiles could be fired every thirty seconds to one minute. In addition, when the missile was first deployed, there was no way for batteries to coordinate fire. Therefore, "several different batteries could engage the same target and allow other targets to pass through." This was remedied within several years, but the early Nike reflected the restrictions of a newly budding computer system. ${ }^{46}$

Nikes were deployed in "fixed firing positions in a circular pattern around key American government/ industrial/ transportation and military locations; the larger the

${ }^{44}$ When the Nike-Ajax was developed, nuclear warheads were still large and too heavy to launch on a missile as small as the defensive Nike.

${ }^{45}$ Carlson and Lyon, p. 31. The Nike-Ajax was operational in the United States until May 1964, but beginning in 1967, installations went overseas to countries within the American sphere of influence. The countries were: Belgium, Denmark, France, West Germany, Greece, Italy, Japan, the Netherlands, Norway, Taiwan, and Turkey.

46 John C. Lonnquest and David F. Winkler. To Defend and Deter: The Legacy of the United States Cold War Missile Program, vol. I. (Champaign, Illinois, 1996), p. 168-169. 
defended area, the more Nike-Ajax sites constructed. ${ }^{247}$ Twelve sites would eventually surround San Francisco. ${ }^{48}$ The deployment of Nike-Ajax batteries around major cities was not widely known by most Americans and was little publicized. To introduce the Nike to the public the Army engaged in public relation campaigns when possible. There were various open house events-most notably during Armed Forces Day. It was during these open houses that missilemen and Army personnel were able to demonstrate the safety features of the Nike to alleviate fears of accidental explosion, provide information regarding national and coastal defense to quell anxieties of vulnerability to attack, and assure communities that Nike sites were not Soviet targets because they were defensive missile systems.

Two such open house events were major news in 1955 when Air Defense bases around the country were open to reporters and visitors alike. The Nike battery at the Presidio in San Francisco was open for public inspection while newsmen were invited to tour the Nike installation guarding the country's capitol. Poised like "pointing fingers" on their launchers for public display, Nike installations were a daunting, but reassuring site. Their image became central to city defense and American security. First and foremost, Americans were told, the Nike was the "military muscle" behind "America's

${ }^{47}$ Berhow, p. 19.

48 The Sites are: (SF-08) San Pablo Ridge; (SF-09) San Pablo Ridge/ Berkeley (double site); (SF-25) Rocky Ridge; (SF-31) Lake Chabot/ Castro Valley; (SF-37) Coyote Hills/ Newark; (SF-51) Milagra/ Pacifica; (SF-59) Fort Funston/ Mt. San Bruno; (SF-87) Fort Chronkhite/ Sausalito; (SF-88) Fort Berry/ Sausalito; (SF-89) Fort Winfield Scott; (SF91) Angel Island; (SF-San Rafael). Two temporary sites were placed at Benicia and Parks AFB in 1955 and 1956. John C. Lonnquest and David F. Winkler. To Defend and Deter: The Legacy of the United States Cold War Missile Program, vol. II. (Champaign, Illinois, 1996), p. 318-319. 
determination to safeguard world peace." To reassure residents of their safety, soldiers brought children up to missiles to touch and sit on. Pictures show eager smiles on their faces. John G. Lunn, Lieutenant Colonal (retired) and former Nike Missileman, recalled his site being open to public visitation each Sunday. "People were welcome to the launching area and given very general explanations about how the missiles worked," he remembered. The children, Lunn added, got very excited. "Once the community perceived we were friendly and our sites were not targets for the Russians, he continued, "they were pretty relaxed." 49

At the Presidio, in San Francisco, more than 15,000 people came to view the Army's new weapon. ${ }^{50}$ The public was told that the Nike "was capable of outmaneuvering and destroying any type of aircraft presently known and foreseeable in the near future." In addition, the "range and altitude of the Nike gives [the Army] the capability to destroy enemy aircraft before they reach a distance from one of our cities from which they could launch their bomb loads." ${ }^{, 51}$ Indeed, the Nike was there to provide city protection, and its image was soon associated with safety. This image of the Nike

${ }^{49}$ John G. Lunn, LTC (Ret.) and former Nike Missileman, Interview by Jessica Barrella, San Francisco, California, July 14, 2006. Another former Missileman remembered that during open house at a Hercules site, bulletin boards, signs, and any potentially classified information was covered with tape and butcher paper before visitors were allowed to enter. Ezio F. Nurisio, Spec. 5, Nike Target Tracking Radar Supervisor, Interview by Jessica Barrella, San Francisco, California, July 16, 2006.

50 "Military Might Shown for Armed Forces Day," San Francisco Examiner, May 22, 1955, p. 3. Accompanying this article is a photo of a soldier with two children (aged two and one half and seven) "sitting astride" the Nike-Ajax to get a close up "of the deadly missile."

51 "Nike Air Defense Base Shown Public," San Francisco Examiner, May 18, 1955, p. 1; "Nike Display for Presidio," San Francisco Examiner, May 18, 1955, p. 6. 
became a central theme in advertisements by major contractors associated with the missile.

Companies used the Nike to link their name brands with patriotic images and safety, therefore allowing Americans to invest in democracy and national security by purchasing their products. Goodyear Aircraft described Nike missiles as "“fireworks' for independence." ${ }^{, 52}$ Douglas Aircraft, one of the primary contractors for the Nike missile system, used the image of the Nike in several of its advertising campaigns-each showing the Nike-Ajax poised and ready to be fired. One advertisement depicted a city with three Nikes in launching position and one already in flight. Douglas promised, "to move missile development from a dream of push-button warfare to a solid reality." ${ }^{, 53}$ The company correlated its name with defense, durability, and dependability in its Nike advertisements: "Selection of Douglas to design Nike recognizes leadership in missile engineering. Selection to build the missile in volume recognizes another Douglas "plus'-manufacturing dependability." ${ }^{54}$ Another ad shows a woman operator plotting a course on a screen with Nike missiles being readied by Army personnel in the background. This time Douglas also unites itself with another form of security, CONAD. After briefly describing CONAD, readers are told that "a major weapon" for protection

52 “'Fireworks'-for Independence Day!” Newsweek, September 24, 1956, pp. 62-63.

53 "Missiles By Douglas," Advertisement, Time, December 7, 1954, p. 2. This ad is also described in Chapter 1.

54 “- The Douglas Built Nike," Advertisement, Undated, From the Personal Collection of Ronald W. Parshall. Convair, as early as 1952 , was also already associating itself with missile technology. They advertised that Convair would operate "America's first plant for the mass production of operational guided missiles." "Engineering to the Nth Power," U.S. news and World Report, July 11, 1952, p. 49. 
was the Nike. ${ }^{55}$ These advertisements helped to bring the importance of the Nike missile into public awareness through mass publication in popular periodicals. Most importantly, however, by aligning company names with the newest defensive technology, readers were able to associate such manufacturers with peace, technological innovation, and reliability during an emergency.

Douglas was not the only manufacturing company that used the Nike-Ajax missile in this way. A Mallory advertisement showed men sitting at tracking stations and Nike missiles launching in the background. Readers were told that Mallory "pioneered capacitors for electronic computing" which provided the means for tracking and intercepting "hostile planes . . . without human delay or error." 56 The Nike-Ajax was the "inner ring of defense" made possible by the "ultra-modern production methods" used by Gardner-Denver. Their automatic "drilling operation" made mass production of the missile possible and made the Nike "plentiful." ${ }^{, 57}$ McGraw-Edison's Instrument Division showed a prominent illustration of a Nike in one of its ads, but does not make a direct link with the defensive missile. Rather it correlates its brand to protection and missile accuracy in general. ${ }^{58}$ Raytheon united itself to an entire arsenal of missiles from the

55 “10,000 Miles of Air Frontier-Under CONAD's Eye," Advertisement, Newsweek, January 30,1956 , p. 75.

56 "New Mastermind for Air Defense," Newsweek, July 30, 1956, p. 85.

57 "Keeping the Nikes Rolling Along," Advertisement, U.S. News and World Report, February 7, 1958, p. 17.

58 “ "There's a Way to do it Better-Find It"” Advertisement. Undated, From the Personal Collection of Ronald W. Parshall. 
Army, Air Force, and Navy. ${ }^{59}$ The image of the missile had become associated with patriotism. Many still feared the new technology, but these ads showed that support for the missile was necessary for national defense. Goodyear noted, Nike missiles would provide a "reception [for] any aggressor who trespassed our skies." ${ }^{, 60}$ For manufacturers, the Nike was synonymous with security and reliability in an uncertain world. ${ }^{61}$

To provide maximum protection, several factors determined the placement of the Nike installations around the United States. Originally Nike missiles were designed to be mobile units, but land restrictions changed this requirement. Staggered sites within and outside city perimeters would provide greater metropolitan protection, and it was decided to place Nike batteries at permanent locations. In addition, underground magazines would reduce the land requirement to only forty acres per site (rather than the 119 acres for mobile locations)—-making land easier to acquire within city limits. ${ }^{62}$ Where possible, the Army used government property- - "even at the costs of tactical considerations." In many cases, land for new missile sites had to be "purchased, leased, or barrowed from other

59 "10 Major U.S. Missiles Rely on Raytheon Tubes," Advertisement, Newsweek, September 8, 1958, p. 74.

60 “ 'Fireworks' - for Independence Day!”

${ }^{61}$ It is interesting to note that when manufacturers used the Nike missile in their advertising, it was only the Ajax that was depicted-not the Hercules. This may have been because the Hercules had a nuclear warhead and not necessarily as public "friendly" as its predecessor.

${ }^{62}$ Lonnquest and Winkler. vol. I, p. 171. 
government agencies, local governments, or private owners." ${ }^{.63}$ Depending on the location, batteries would be located within the cities limits or around its perimeter.

In late 1952, the Army Corps of Engineers (responsible for the placement of the batteries) determined that closer-in perimeters "would provide enhanced firepower" and would offer better defense capability. Limited city land usually restricted their location to public-parks. In these cases the Army was sometimes faced with public protest because of concerns with safety issues. ${ }^{64}$ Apprehension was illustrated in an article by Time which reported, "While doing their defending duty, the Nikes will not be desirable neighbors. The boosters that bounce them into the air are big enough to do damage when they fall to the ground and so are the Nikes themselves. But Army ordinance can point out that this rain of angular metal would be better than the flash and blast of enemy atom bombs." These were the very fears that Nike open house days were attempting to calm.

San Franciscans were alerted to the deployment of antiaircraft Nike missile batteries to their area in early 1954 - only six months after the first battery was installed at Fort Mead, Maryland. ${ }^{66}$ That same year, Armed Forces Day was proclaimed "Power

\footnotetext{
${ }^{63}$ Morgan and Berhow, p. 9.
}

64 "Nike-Ajax (SAM-A-7) (MIM-3, 3A)," Federation of American Scientists, http://www.fas.org/nuke/guide/usa/airdef/nike-ajax.htm: Lonnquest and Winkler. vol. I., p. $165-173$.

65 "Winged Victory," Time, April 6, 1953, pp. 77-78. Indeed, in 1955, a Nike missile went array during an alert exercise in San Francisco. But because its warhead can only explode while in flight, no one was hurt. "Nike Missile Falls on Highway: None Hurt," San Francisco Examiner, April 15, 1955, p. 1.

${ }^{66}$ It has been commonly reported that the first Nike missile installation was deployed in March 1954. That is not the case: the accurate date is December 1953. By spring of 1954, Nikes were systematically being deployed around the country. "Nike-Ajax Fact Sheet," 
for Peace." The new weapon was showcased and residents were told that it was "designed to protect San Francisco and other perspective target cities from air attack." City residents were also told that this was the first public viewing of the new closely guarded weapon. "Covers were pulled from the hitherto top secret antiaircraft weapon for the first time in the Bay Area and in one of only a few such displays anywhere in the United States." ${ }^{, 68}$ The Nike missile, it was explained, was "designed to knockout enemy aircraft which get through the Air Force fighter interceptor screen." The Air Force boasted that, "it is almost impossible for [the Nike] to miss a target." ${ }^{\circ 9}$ The Army disclosed enough information about the Nike for people to feel secure about its presence.

By July 1954, five Nike installations were announced for the Bay Area, "a focal point in the network designed as the nation's first line of defense against atomic attack from the air." ${ }^{70}$ John G. Lunn believed that the general feeling at the time was that "if an area was important to defend, it must have been a Russian target." The Nikes were in

U.S. Army Ordnance Missile Command, Public Information Office, Undated, KSC Archives, Missiles, box 30A.1, folder 3.

67 "First NIKE Display at Armed Forces Day," San Francisco Examiner, May 10, 1954, p. 38.

68 "Former Top Secret Weapon Shown Here: Nike Missile Unveiled at the Presidio," San Francisco Chronicle, May 14, 1954, p. 7.

69 "Nike Shown in Preview at Presidio," San Francisco Examiner, May 14, 1954, p. 9. "Guided Missiles 'Stars' of Armed Forces Day: Supersonic Jets on Exhibit, Too," San Francisco News, May 14, 1954, p. 2.

${ }^{70}$ The locations were Fort Baker, Fort Chronkhite, Fort Berry, the Presidio, and Lake Chabot. It was wrongly reported that the Nike was the first line of defense. It was actually the last line of defense. "Guided Missile Base Selected at Presidio: 2 Other Locations in Bay Area Picked," San Francisco Examiner, July 7, 1954, p. 1. 
place and "ready for launching" by the end of October. ${ }^{71}$ These installations "substantially defended [San Francisco] against hostile attack," it was announced. ${ }^{72}$ To residents of the city, this was comforting considering the alarmist reports of city vulnerability, snags in civilian defense, and newly released information on thermonuclear developments reported in the local newspapers. The Nike, it appeared, would protect the city from attack, but internal protective measures would continue to plague the city.

In early February 1954 it was revealed that the civil defense officials of San Francisco were unsure how to proceed during an air raid drill. "San Francisco's air raid alert plans are so confusing at the moment that if enemy planes were threatening no one would know whether to order the citizenry into shelters or into mass flight," disclosed the city's civil defense director. It appeared that the city had plans for both dispersal and evacuation. It was not clear until after the "snafu" was revealed that the federal government's radar network was incapable of giving "sufficient warning to allow people to carry out 'mass dispersal'- to head for the hills." ${ }^{, 73}$ This led to the assumption that there would not be adequate time to take shelter, "especially if the [enemy] bombers

${ }^{71}$ John G. Lunn Interview.

72 "Nike Missiles Set Up Here, Ready to Fire: Supersonic Weapons Protect Area Against Air Attack," San Francisco Examiner, October 22, 1954, p. 7; "More Nike Bases Slated for Bay Area: New Missile Installations to Bring Total to 12," San Francisco Examiner, November 2, 1954, p. 7.

${ }^{73}$ Jack Foisie, "Big Civil Defense Snafu: Run or Hide-No One is Sure," San Francisco Chronicle, February 3, 1954, p. 1; Jack Foisie, "Civil Defense Snafu Cleared Up: S.F. Dispersal Plan Can't be Used Yet," San Francisco Chronicle, February 4, 1954, p. 1; "Official Civil Defense Plan Still Is: 'Hide!" San Francisco Chronicle, February 5, 1954 , p. 5. 
came in fast and low." "74 "As a potential casualty in any air raid on San Francisco," one

resident wrote about their own personal misgivings concerning civil defense preparations:

The State and Federal plans call for mass dispersal, but its effectiveness demands a margin of warning that is impossible to guarantee ... Furthermore, some opinion contends that instead of planes we may expect guided missile attacks from submarines. Even assuming that a comprehensive radar net detected planes long in advance, is each major U.S. city to evacuate in the face of every alert coming from a distant post? Though a bomb were never dropped (sic), could not we be kept in a state of perpetual chaos? Can anyone imagine evacuating San Francisco in a few hours? And what do we do about the people who are not mobile? The problems are infinite. $^{75}$

Soon after the glitches in civil defense were revealed, Americans were warned of a possible enemy bomb conspiracy on American soil. The Federal Bureau of Investigation alerted San Francisco and other major cities of "enemy saboteurs sneaking 'suitcase A-bombs' into the country."76 This warning provoked newsmen from Los Angeles to plant "simulated suitcase A-bombs at vital West Coast target points" for the sake of showing "it can be done"-and they were successful. One mock-bomb was hidden on the Golden Gate Bridge. As threats of hidden atomic bombs emerged around

\footnotetext{
74 "No Place to Hide in San Francisco," Editorial, San Francisco Chronicle, February 4, 1954, p. 14.
}

75 W.A. Hayne, "Civil Defense," Letters to the Chronicle, San Francisco Chronicle, February 14, 1954, p. 18.

76 "FBI Alerts S.F., Other Cities to Look for "Suitcase A-Bombs," San Francisco News, March 23, 1954, p. 1. Interestingly, the FBI was not able to describe what to look for, stating that it would be "impossible to describe exactly what a foreign atomic bomb would look like, since the materials could be carried together in a device ready for explosion or separately, to be assembled later." But the Coast Guard, in the same article noted that they had been "on the lookout for smuggled atomic weapons for months" and they knew "what to look for." 
the country, new information was being publicly released about the destructive capabilities of hydrogen weapons. ${ }^{77}$

Almost 400 miles away from San Francisco, nuclear detonations at NTS continued and the explosions grew larger. It was speculated that a "city buster" weapon being "designed for an intercontinental guided missile," was the cause of windows rattling as far away as 370 miles. ${ }^{78}$ In early 1954 , Americans for the first time were told of the power of thermonuclear weapons. "The vast explosion which wiped out an island in 1952 . . was a full scale test of devices leading to a hydrogen bomb."79 The hydrogen explosion "completely obliterated the test island," and it "gashed a crater in the ocean floor a full mile in diameter and 175 feet deep." The crater was "large enough to fit 140 structures the size of the nation's Capitol." Vulnerability was intensified when AEC Chairman Lewis L. Strauss announced that the hydrogen bombs in the arsenal of the United States "were powerful enough to wipe out an entire metropolitan area" the size of New York. ${ }^{80}$ Most frightening was that it was believed the Russians would soon have the

77 "Fake Atom Bomb Put on Gate Bridge: L.A. Newsmen Hide Imitation of 'Suitcase' Weapon in Defense Tests," San Francisco News, April 7, 1954, p. 1.

78 "Cloud of A-Bomb Heading for L.A: "City-Buster' Blast Set Off in Nevada," San Francisco News, March 7, 1954, p. 1: "S.F. Views Blast as Biggest Yet," San Francisco News, March 7, 1954, p. 4.

79 "Wilson Tells Policy: U.S. Ready to Use Atomic Weapons in Future Wars," San Francisco Chronicle, February 3, 1954, p. 7; "Ike Confirms Hydrogen Test Blast in 1952," San Francisco Chronicle, February 3, 1954, p. 7.

80 ، '1 Hydrogen Bomb Can Cripple N.Y': Atomic Chief Reveals Huge Power of Blast," San Francisco News, March 31, 1954, p. 1. 
same thermonuclear capability and use it against the United States." ${ }^{\prime 11}$ Defense Secretary Charles E. Wilson compounded fears when he announced that atomic weapons would be used in "any future Korean-type war as well as any global conflict.",82

Residents of San Francisco were not pleased to hear about the tremendous power of thermonuclear weapons. One local questioned the need to continue nuclear testing: "I see that we have left the "Atomic Age" behind and entered the "Era of Mad Scientists" or "Experimentation at Any Price! . . . Since [scientists] have effectively demonstrated the damn thing works, are they going to keep on proving their theories until they reach the "Z" (End of It All) Bomb?" Other residents questioned whether American tests were more detrimental than threats from the enemy and called for international control of atomic weapons. ${ }^{83}$ As we have seen in Chapter 2, disarmament was not forthcoming. Rather, the government assured Americans that the Soviet threat would be matched with a mass-produced arsenal of defensive missiles. Chairman of the Senate-House Atomic Energy Committee, Sterling Cole (R-NY) told the public that the United States had within its capacity the ability to "produce 'tens of thousands' of atomic anti-aircraft defensive missiles as 'a barrier of atomic firepower." ",84 Indeed, it was at this time that the United States Army began to deploy its first surface-to-air defensive missile: the Nike.

81 "Expert Hints U.S. has Bigger H-Bombs: $1^{\text {st }}$ One Wiped Out Island," San Francisco Examiner, February 18, 1954, p. 1.

82 "Wilson Tells Policy: U.S. Ready to Use Atomic Weapons in Future Wars," San Francisco Chronicle, February 3, 1954, p. 7.

\footnotetext{
${ }^{83}$ Anne E. Nelson, "Absurdity, Too"; Anne E. Nelson, "Z-Bomb"; Stanton A. Coblentz, "H-Bomb," Letters to the Editor, San Francisco Chronicle, April 4, 1954, p. 20.

84 "Expert Hints U.S. has Bigger H-Bombs."
} 
The defensive missile soon became the next technological answer to growing public fear of a devastating nuclear attack.

Another byproduct of nuclear testing at the NTS was the dangers of radiation and fallout. Wind patterns dictated danger areas, and because they were random, scientists could not predict the path of fallout. Nevada's neighbor states, however, were constantly assured by the AEC that fallout from the NTS was minimal and did not jeopardize the safety of Americans. But radiation contamination came to the fore when it was reported that Japanese fishermen were contaminated by radioactive fallout from a hydrogen bomb blast in the Pacific. The Lucky Dragon fishing boat was eighty-five miles east of Bikini Atoll and outside the designated "danger zone" of American testing. When Lucky Dragon returned to Japan two weeks later, it was obvious that the crew suffered from radiation poisoning. Remembering Hiroshima and Nagasaki, the people of Japan were alarmed, and this fear soon spread to the United States. ${ }^{85}$ The United States government was reluctant to admit that such an incident did occur, but paid the victims. This action underscored American nuclear testing was at fault and proved to many that scientists could not control such violent explosions. Perhaps the development of thermonuclear weapons was tempting fate. ${ }^{86}$

${ }^{85}$ Robert A. Divine, Blowing on the Wind: The Nuclear Test Ban Debate, 1954-1960," (New York, 1978), pp. 2-8.

86 "U.S. Sends Aid to H-Bomb Victims," San Francisco News, March 20, 1954, p. 1. By autumn of that year, Japanese blast victims begin to die. "Japan Victim of Hydrogen Bomb Dies: Crisis with U.S. Seen Over Pacific Accident," San Francisco Examiner, September 24, 1954, p. 1.

Tomas L. Stokes. "'Out Of Control' Atomic Blast Stirs Concern by Scientists," Editorial, San Francisco News, March, 23, 1954, p. 16. 
The release of brilliant color photos of hydrogen tests caused local anxietyespecially concerning preparation and civil defense. ${ }^{87}$ Speculation about what could happen to San Francisco began immediately - the same day the hydrogen bomb photos were released. The San Francisco News showed an aerial map of the Bay Area with concentric rings drawn over it representing a hydrogen bomb's ten-mile radius of destruction. ${ }^{88}$ The grossly enlarged area of devastation in the Thermonuclear Age called into question the means of protection used in the Atomic Age-one that paled in comparison. ${ }^{89}$ Still residents of the city were encouraged to evacuate: "if a hydrogen or atomic bomb is exploded over San Francisco," Federal Civil Defense Administrator Val Peterson said, "the only sure way to save your life is not to be there." 90 The San

87 "First H-Bomb Pictures! An Island Vanished in an Instant," San Francisco News, April 1, 1954, p. 1; "First H-Blast: Man Makes Chaos," San Francisco Chronicle, April 2, 1954, p. 1; "Dome of Fire: H-Blast Film Released: A Record of Devastation," San Francisco Chronicle, April 2, 1954, p. 1; "Is the H-Bomb Going Wild: Island Buster Is a far Cry from Model Originally Planned," U.S. News and World Report, April 9, 1954, pp. 21-26; "H-Bomb Blast in Color," San Francisco Chronicle, April 12, 1954, p. 1; "Between Yesterday and Today," Newsweek, April 12, 1954, p. 41; "5-4-3-2-1 And the Hydrogen Age is Upon Us," Life, April 12, 1954, pp. 24-33; "H-Bomb Over the Pacific," Time, April 12, 1954, cover.

88 "If S.F. Were an H-Bomb Target," San Francisco News, April 1, 1954, p. 2. Also see: Jack Steele, "What's Our Chance of Survival if H-Bomb Strikes," San Francisco News, April 20, 1954, p. 4; "H-Bomb Peril to Industry of U.S. Bared," San Francisco Examiner, May 4, 1954, p. 14.

${ }^{89}$ Jack Steele, "Hide and Run' Theories of Civil Defense Called Useless Against HBomb Attack," San Francisco News, April 4, 1954, p. 3; "S.F. Warned to Plan H-Bomb Defense Now: City Unprepared Peterson Says," San Francisco Examiner, April 6, 1954, p. 11; Jack Foisie, "H-Bomb Doesn't End Need for Wardens," San Francisco Chronicle, April 7, 1954, p. 5.

90 "S.F. Civil Defense Still Held Vital; Evacuation Plan Asked," San Francisco Examiner, April 7, 1954, p. 5. He also described the hydrogen bomb as a "tremendously devastating weapon" and noted that civil defense planning from only one year ago "was 
Francisco Chronicle reminded citizens that the hydrogen bomb was the "worst weapon of all."91 The San Francisco News testified, "people are scared," and many were demanding that H-bomb tests be stopped. ${ }^{92}$

Letters and editorials flooded the local newspapers regarding public concern about thermonuclear weapons and questioning civil defense methods. Resident Margaret Garner called evacuation "mass suicide" and urged world peace as "imperative for survival." ${ }^{93}$ Mrs. C. A. Rombach doubted the policy of nuclear deterrence: "Naturally people are alarmed, they are confused and frightened and considering the contradictory statements of the last few weeks [by the AEC], they have reason to be. It will take more than 'speeches' promises and assurances to remove the fear, the fear EXISTS." ${ }^{\text {"94 }}$ C.H. McCaslin wrote, "I say stop trying to frighten the Russians by scaring the wits out of us at home." She asked for more transparency regarding the effects of the hydrogen bomb to

changed because of it." "Hiding H-Bomb News Wrong, CD Chief Says," San Francisco Examiner, April 5, 1954, p. 1. Indeed, the Civil Defense office of San Francisco relocated fifty miles outside of the metropolitan area "in the event of a hydrogen bomb attack." Jack Foisie, "Civil Defense Office to Move 50 Miles Out," San Francisco Chronicle, April 9, 1954, p. 1.

${ }^{91}$ William L. Laurence, "Worst Weapon of All," San Francisco Chronicle, April 8, 1954, p. 1.

92 "CDA Offers Some Advice on H-Bomb: 'Mass Evacuation' Only Answer Now," San Francisco News, April 3, 1954, p. 1.

${ }^{93}$ Margaret Garner, "World Peace is Now Imperative for Survival of Human Race," Pulse of the Public, San Francisco News, April 4, 1954, p. 22.

${ }^{94}$ Mrs. C. A. Rombach, "Unbelievable H-Bomb Creates Fear of War in People," Pulse of the Public, San Francisco News, April 7, 1954, p. 20. 
better prepare for an attack. "The time is here for civilization to control this instrument and stop war if it would save itself and not perish," one local newspaper editorial reasoned, and called for disarmament. Another hoped that a Russian proposal for disarmament was legitimate and noted that the "H-bomb may be on the way to working a miracle that no amount of negotiation based on lesser persuasion could work." ${ }^{96}$ Others, while not calling for disarmament, did agree that hydrogen weapons created fear, but the challenge, they argued, was to live and adapt to their existence. "We have to live with it. We have no choice. We cannot run from it. There is no sense or safety, either in panic or the shrill cries that we stop making the bomb. The bomb may not prevent an attack on America-but if it can't nothing will. ${ }^{, 97}$ Contrary to other complaints, one editorial did call for "patriotism over politics," and demanded that the United States and Europe accept testing and development of thermonuclear weapons as a feasible deterrent. Sentiments such as this were rare. ${ }^{98}$

${ }^{95}$ C.H. McCaslin, "H-Bomb Facts, Not Scares, Called Need of U.S. Cities," Pulse of the Public, San Francisco News, April 9, 1954, p. 22.

96 Thomas L. Stokes, "Time is Now for a New Move to Control H-Bombs, Stop War," Editorial, San Francisco News, April 7, 1954, p. 20; "The Logic of the H-Bomb," Editorial, San Francisco Chronicle, April 9, 1954, p. 18. The Soviet Union was credited with disclosing information about the effects of hydrogen weapons to their citizens. "Russ Tell of H-Bomb Effects," San Francisco Chronicle, May 7, 1954, p. 10.

97 "The Real "New Look," Editorial, San Francisco News, April 7, 1954, p. 20; Royce Brier, "This World Today: Beating the Bomb," Editorial, San Francisco Chronicle, April 9, 1954, p. 18; "How to Dodge H-Bombs," Editorial, San Francisco Chronicle, May 6, 1954, p. 18.

98 Ludwell Denny, "Appeasement Due to H-Bomb Called West's Greatest Peril," Editorial, San Francisco News, April 2, 1954, p. 22. 
Concerns abounded, but the hydrogen bomb was not yet a direct threat because its means of deliverability still needed to be perfected. Meanwhile SAMs continued to be deployed around the United States, guarding primary target cities in the event of Soviet attack with airplanes. By the mid-1950s the Army began to modify the Nike missile: its flight range would increase, and more importantly, nuclear warheads would replace conventional explosives. The improved missile was designated Nike Hercules.

Research and development studies to improve the Nike-Ajax began in 1953before the Ajax was first deployed. 99 "Limitations of the Nike-Ajax system (including the inability to discern individual bombers within a densely-packed flying formation)," forced the Army to "explored the feasibility of equipping the Ajax with a nuclear warhead." This proved impractical because significant modifications needed to be made to the Ajax missile itself. The ground guidance equipment, however, would only need slight changes. The resulting product was the Nike Hercules. Both the Nike-Ajax and the Hercules were designed to function with a command guidance system-as opposed to a homing system or beam rider system. The command guidance system steered the missile "while in trajectory" through a series of commands transmitted from equipment on the ground. Because the Nike Hercules was "designed to use the supporting components of the Nike-Ajax system," both missiles were simultaneously employed. The nuclear capability of the Hercules allowed the missile to destroy more enemy targets

99 "Nike-Hercules Fact Sheet," U.S. Army Ordnance Missile Command, Public Information Office, Undated, KSC Archives, Missiles, box 30A.1, folder 2. 
simultaneously and at a further range. The Ajax, on the other hand, was retained "for use against single aircraft at shorter ranges. $" 100$

Improved Soviet weapons made it evident that a new and improved version of the Nike-Ajax was needed. ${ }^{101}$ The rapid development of sophisticated Russian weapons heightened concern about national public defense. Coastal cities were threatened by flights over the Arctic and Russian submarine-launched missiles out at sea. In 1954 San Franciscans were told that Russian submarines were detected off the coast of their city. It was hypothesized that they were taking "periscope photographs" to "plot the course of a guided missile launched from a submarine far at sea." ${ }^{\prime 02}$ It was also speculated that soon Russian submarines would have the capability to launch thermonuclear weapons. ${ }^{103}$ Fears escalated when in 1955, Soviet Foreign Minister Viacheslav M. Molotov boasted that the Soviet Union had developed a hydrogen bomb so sophisticated that it made the United States appear "backward." 104 Despite scientists predictions that advances in weaponry

100 "'Introduction to the Improved Nike Hercules Missile System."

101 "Russ Testing New Series of Atom Bombs: AEC Reports Blasts Began in MidSeptember," San Francisco Examiner, October 27, 1954, p. 1.

102 "Red Submarines Detected Lurking Off Pacific Coast: U.S. Navy on Watch," San Francisco Examiner, September 27, 1954, p. 1. Shortly after this warning, San Franciscans were also informed that the Soviets had the capability to send missiles from Siberia. "Alaskan Air Bases Threatened by Soviet Rocket Missiles from Siberia," San Francisco Examiner, November 7, 1954, p. 8.

103 "Small 'H' Weapon for Sub Firing Hinted," San Francisco Examiner, April 24, 1955, p. 16. Interestingly, the Russians had the same fears of the United States. M. Gvozdev and V. Iakovin, Atomnoe oruzhie i protivo atomnaia zashchita (Atomic Weapons and Anti-Atomic Defense) (Moscow, 1958), p. 54.

104 Joseph Oppenheimer, "Red H-Bomb Claim Rapped," San Francisco Examiner, February 10, 1955, p. 6. 
would create an "atomic stalemate," government officials promised swift "automatic retaliation" if attacked. ${ }^{105}$ In San Francisco, this declaration did not assure residents; rather, it spurred increased civil defense planning to prepare for attack and possible war.

San Francisco newspapers inundated readers with information regarding civil defense during nuclear attack. Almost daily there were reports of what to do, where to go, meetings being held, and national debates. ${ }^{106}$ The incredible power of thermonuclear weapons was apparent to Americans, but the weapons continued to be shrouded in mystery. The federal government and the AEC were reluctant to give out enough information about nuclear weapons for residents to feel safe. In the name of national security, much was left unsaid, and as a result, imaginations went wild. With the apparent lack of information concerning safety, residents worried about their vulnerability to enemy attack and to the effects of national testing. ${ }^{107}$ Under these conditions it appeared

${ }^{105}$ Darrell Garwood, "U.S., Russian Atomic Stalemate Feared," San Francisco Examiner, November 22, 1954, p. 2; Elton C. Fay, "U.S. Set for Quick A-Bomber Attack if Enemy Strikes: Retaliation Automatic," San Francisco Examiner, March 14, 1955, p. 1.

106 "Schools Set CD Test: Contra Costa Children Rehearse Monday," San Francisco Examiner, November 19, 1954, p. 4; "Civil Defense Classes Set," San Francisco Examiner, January 3, 1955, p. 19; "H-Bomb Survival Topic for St. Mary's Guild Discussion," San Francisco Examiner, March 24, 1955, p. 25; "Parents Will be Polled on A-Attack Plan: Alternatives to Children Told: First Step in S.F. Survey," San Francisco Examiner, April 16, 1955, p. 12; "Family in Bomb Survival Test Lives 3 Days Isolated in Home," San Francisco Examiner, April 18, 1955, p. 6; "Mayor Backs Publicity Campaign to Inform S.F. of Disaster Plans," San Francisco Examiner, May 11, 1955, p. 8.

${ }^{107}$ In spring 1955, NTS had another highly anticipated test series, which was seen and felt in the Bay Area. "New Atomic Tests Set for Nevada in Spring," San Francisco Examiner, September 25, 1954, p. 6; "Big Test A-Bomb Felt in Bay Area," San Francisco Examiner, March 8, 1955, p. 1; "Flash from A-Blast Lights Sky in S.F." San 
that San Francisco did its best to prepare for the inevitability of nuclear war, but at the time, such conflicting information was frustrating to residents. ${ }^{108}$

In 1954 San Francisco was once more the center for a national air raid drill. The "strengthened network of radar warning stations in the Arctic" determined that the civilian populations of key cities would be evacuated and not sent to shelters. This policy caused worry about false alarms and many residents questioned the lack of federal funding for shelters. ${ }^{109}$ Newspapers reported that not only was a national shelter project deemed too expensive, but-in light of Lewis Strauss' comment on the ability of a thermonuclear weapon to "take out a city"-it was probably a useless form of civil defense. ${ }^{110}$ Residents were told, "The Japanese experienced only the fire cracker stage of

Francisco Examiner, May 6, 1955, p. 4; "Underwater Atomic Tests Blast Planned at Sea off West Coast," San Francisco Examiner, May 10, 1955, p. 2.

108 Thomas L. Stokes, "Atomic Era Advances, but U.S. Still Lacks CD Plan," Editorial, San Francisco News, March 8, 1955, p. 14; "Gap in Internal Security Plans Frightens CD: Industry Handling of Secret Data Rapped," San Francisco News, March 12, 1955, p. 1; "How Civil Defense Plans to Handle Evacuation of City: Hour's Warning! Many to Flee, Some Must Return," San Francisco Examiner, March 27, 1955, p. 1; "Supervisors Rap S.F. Civil Defense Setup," San Francisco Examiner, May 10, 1955, p. 12; "U.S. Civil Defense Funds Cut in House Bill: Greater State, Local Share Urged," San Francisco Examiner, March 17, 1955, p. 21; "Senators Ask Ike to Take Charge of HBomb Attack Civil Defense," San Francisco Examiner, May 20, 1955, p. 7.

109 Jack Eshleman, "S.F. Bomb Refugees Face Long Flight," San Francisco Examiner, March 30, 1954, p. 1; Jerome Lanfield, "Civil Defense," Editor's Mail Box, San Francisco Examiner, November 10, 1954, p. 26.

110 "CD To Hold A-Bomb Raid Drill in S.F." San Francisco News, June 12, 1954, p. 1; “ 'Run-and-Duck' Formula Best Yet Devised Against H-Bomb," San Francisco News, October 10, 1954, p. 5. 
the atomic era." 111 This reignited the debate about the best means for civilian protection. Defects in national defense were evident as false alarms plagued the country, but civil defense participants were not discouraged.

Many San Franciscans felt that doing something was better than doing nothing at all. Critics of civil defense were chastised for not participating in civil defense organizations-or at the very least not suggesting alternate solutions. ${ }^{112}$ Letters to local newspapers reflected public concerns about civilian defense and nuclear attack, but even with preparation, there was a feeling of despair. One San Franciscan simply asked for honest information regarding a nuclear emergency, while another resident wrote that if a nuclear bomb were dropped on the city, he would not "run for the hills," but would rather "be blown to pieces at one place as another." ${ }^{113}$ It was apparent that new methods of defense were needed.

The Nike Hercules (MIM-14/14A/B) was the second generation Nike and much larger missile than its predecessor. The Hercules was over forty-one feet long, and had a

111 "S.F. Doctor Role Told in Case of H-Bomb Attack: Aid Method Discussed," San Francisco Examiner, June 21, 1954, p. 1.

112 J.H. Mills, "Volunteer Warden Replies to Unfair Civil Defense Critics," Pulse of the Public, San Francisco News, October, 10, 1954, p. 16; C.A. Overhausse, "Defense of Civil Defense," Editor's Mail Box, San Francisco Examiner, November 2, 1954, p. 26; W.W. Bauer, M.D. "How to Survive Disaster," Editorial, San Francisco Examiner, November 23, 1955, p. 35.

113 R.N.H. "Defense of Civil Defense," Editor's Mail Box, San Francisco Examiner, November 2, 1954, p. 26; G.W. Murray, "Defense of Civil Defense," Editor's Mail Box, San Francisco Examiner, November 2, 1954, p. 26. There were contradictory reports concerning exposure to radiation. One said that $\mathrm{x}$-rays were more dangerous than radioactive fallout. Darrell Garwood, "H-Bomb Test Danger Held Less Than X-Ray," San Francisco Examiner, January 3, 1955, p. 18; "Hiroshima Report: Few Hereditary ABomb Effects: Long Range Result," San Francisco Examiner, March 30, 1955, p. 1. 
diameter of thirty-one and one-half inches. Its booster was a cluster of four Nike-Ajax rockets fueled with a solid fuel propellant. At launch, it weighed 10,405 pounds. The Nike Hercules was able to reach an altitude of up to 150,000 feet with a range of over seventy-five miles (this too would increase). Perhaps the most important advantages over the Nike-Ajax was it was equipped with a nuclear warhead-although it could be fitted with conventional high-yield explosive-and it had surface-to-surface capability, extending its importance by versatility.

As the Nike Hercules was being readied for mass production and deployment, an improved version was deemed necessary to enhance "acquisition and tracking radar capabilities that would further exploit" the potentialities of the missile. By 1956, studies indicated that the basic Nike Hercules could be "improved to meet the anticipated post1960s threat" with no change to the missile itself. This missile was dubbed the "Improved Hercules." A High Powered Acquisition Radar (HIPAR) was installed to "detect highspeed, non-ballistic targets" with "greater range" (replacing the Low Powered Acquisition Radar-LOPAR). ${ }^{14}$ In addition, Target Tracking Radar was improved and Ranging Radar was added, "to counter [anticipated] enemy radar jamming attempts."115

${ }^{114}$ A homing system guides the missile by "locking on energy emissions or reflections from the target." A beam radar system captures the missile in flight once it has been launched. It follows the beam to the target. The Improved Nike Hercules was capable of three kinds of missions: surface-to-air, surface-to-air low altitude, and surface-to-surface. "Introduction to the Improved Nike Hercules Missile System," Obtained at: http://www.nikemissile.org/.

${ }^{115}$ Nike Hercules (SAM-N-25) (MIM-14/14A/14B), http://www.fas.org/nuke/guide/usa/airdef/nike-hercules.htm; John C. Lonnquest and David F. Winkler. To Defend and Deter: The Legacy of the United States Cold War Missile Program, vol. I. (Champaign, Illinois, 1996), p. 177-182. 
The Improved Nike Hercules also had changes in the command and control of the firing batteries, which allowed for coordination between batteries (the Nike-Ajax system's "operational combat control ultimately rested with the individual batteries"). This would eliminate duplication in missile targeting and ultimately save precious time during an attack.

The Nike was becoming an increasingly complex and yet sophisticated system. Before 1957, Army Air Defense Post operations were limited to manual operations "utilizing plotting boards." This was time consuming and open to error. The Hercules relied on automation for plotting and targeting. The automated control system designed to replace the manual system was Missile Master (AN/FSG-1). This system had its own radars, computers and "electronic plotting devices that enabled the coordination of target acquisition, tracking, and battery firing." The system was housed in a semi-hardened concrete blockhouse and "could monitor 24 sites against 50 individual targets." ${ }^{116}$ Missile Master was used in large defense areas to coordinate multiple batteries. In contrast, Battery Integration and Radar Display Equipment (BIRDIE) was designed for smaller defense areas or single battalion defenses (eventually Missile Master was replaced by Missile Mentor). 117 "Through Missile Master, BIRDIE, and Missile Mentor, each ARADCOM battery was effectively linked with the entire North American Air Defense

\footnotetext{
${ }^{116}$ Berhow, p. 21.

${ }^{117}$ Lonnquest and Winkler, vol. 1, p. 179; Berhow, p. 22.
} 
System (NORAD) through their central control." ${ }^{118}$ Homeland defenses were now more effective, with little chance of duplication or gaps.

The first Nike Hercules missiles were deployed on June 30, 1958, to Chicago, New York, and Philadelphia defense areas-less than a year after the launch of Sputnik. Site SF-88 (Fort Berry/ Sausalito) in San Francisco received its first Hercules missiles the same year. Four other San Francisco sites were upgraded to hold the new missile: SF-31 (Lake Chabot/ Castro Valley); SF-51 (Milagra/ Pacifica); SF-87 (Fort Chronkhite/ Sausalito); SF-93 (Angel Island). Because the Hercules was more effective than the Ajax, fewer needed to be deployed to a single defense area. Sites located further away from metropolitan areas were more desirable locations due to the Hercules' nuclear warhead. The Hercules was designed to use Ajax sites, but existing locations were often located in or near heavily populated cities. ${ }^{119}$

Sites had to be converted because of the Hercules size. Modified magazines were limited to only six missiles (compared to between ten and twelve Ajax missiles). In all, the Army deployed 145 Nike Hercules batteries, thirty-five of which "were built exclusively for the new missile" and the other 110 were converted Ajax sites. ${ }^{120}$ During the course of the Cold War, 10,077 Hercules missiles were produced. The nuclear tipped missiles led to increased security measures on the batteries. A double fence enclosure

${ }^{118}$ Morgan and Berhow, p. 16.

${ }^{119}$ Lonnquest and Winkler, vol. II, p. 319. This was especially true in primary target areas, which received the first Nike-Ajax batteries.

${ }^{120}$ Ibid., p. 177. All the Hercules sites in the United States were deactivated by 1975 except those in Alaska and Florida, which were deactivated in 1979 and 1978 respectively. In Europe, the Hercules stayed active until 1988. Schwartz, p. 282-283. 
topped with razor wire distinguished Hercules sites from Ajax sites. ${ }^{121}$ But the most visible deterrent, perhaps, was the addition of sentry dogs.

Sentry dogs were assigned to all Nike Hercules sites to augment security and for night patrolling of the launching area. "On average, there were four dogs per site." Each dog was assigned to a single handler who was responsible for its training. They were trained to be "overly aggressive" and to respond only to their handler. "On occasion, a dog would get loose from its pen. When this would happen you would see soldiers scramble to get to a safe place" for fear of being attacked. If a handler could not be replaced when he left base, the sentry dog would have to be put to sleep. ${ }^{122}$

Department of Defense's "Nuclear Weapon Personnel Reliability Program" (PRP), and what the Army commonly referred to as "Need to Know" information provided another precautionary measure. ${ }^{123}$ For Nike missilemen, this meant screening of personal and family history in addition to very tight security on base. The level of knowledge and operations was closely controlled, and soldiers were not encouraged to

${ }^{121}$ Abandoned Nike Hercules batteries around the San Francisco Bay Area can still be identified by these characteristics today - the double chain-link fence topped with razor wire.

122 Ronald W. Parshall Private Nike Electronic Equipment Repairman and Launcher Crew, Interview by Jessica Barrella, San Francisco, California, July 14, 2006; http://www.nikemissile.org/sentry dogs.htm.

Although the disposal of the Sentry dogs was sad, it was necessary because they were unmanageable and trained to kill. Their behavior could not be modified.

${ }^{123}$ Ezio F. Nurisio, Spec. 5, Nike Target Tracking Radar Supervisor, Interview by Jessica Barrella, San Francisco, California, July 16, 2006; "Nuclear Weapons Personnel Reliability Program," Number 5210.42, Department of Defense Directive; "DOD Directive," obtained at: http://www.fas.org/nuke/guide/usa/doctrine/dod/dodd$521042 . \mathrm{htm}$. The code adopted by the Air Force was Regulation 35-9, referred to in Chapter 2. 
socialize with other soldiers of different areas of operation-even within the same battalion. If the weapons had nuclear warheads it was considered "Need to Know," and this information was limited to the men working in "the pit" (magazine) and launching area. Each man's focus was on his individual job. ${ }^{124}$ The launcher area and the IFC personnel had separate barracks and did not sit together during meals. Nike sites with two launching areas had two separate launching teams, and although they had the same job, socialization was not encouraged. ${ }^{125}$ Rather, competition between areas of occupation was very strong. Communication was discouraged, but "comadery was high."126 The Army also had a "2-2 rule" to prevent unauthorized launchings of nuclear Nike Hercules missiles. The rule referred the number of men allowed in the launching area: no single man was admitted in the launching area or allowed in "the pit" alone. ${ }^{127}$

Those who served as Nike Missilemen were originally trained for field artillery, and "were handpicked as distinguished graduates" to operate the Nike Program. "It was a privilege," recalled John G. Lunn. Most of the men were nineteen and twenty years old-

$124 \mathrm{Al}$ Kellogg, SPC4, ABAR (Alternate Battery Acquisition Radar) Electronic CounterCounter Measure, Nike Missile System, C Battery, 2nd, 51st Artillery, San Rafael, CA, and former Nike Missileman, Interview by Jessica Barrella, San Francisco, California, July 16, 2006.

${ }^{125}$ Ronald W. Parshall, Private, Nike Electronic Equipment Repairman and Launcher Crew, Interview by Jessica Barrella, San Francisco, California, July 14, 2006.

${ }^{126}$ Ezio F. Nurisio Spec. 5 Nike Target Tracking Radar Supervisor, Interview by Jessica Barrella, San Francisco, California, July 16, 2006; John G. Lunn, LTC (Ret.) and former Nike Missileman, Interview by Jessica Barrella, San Francisco, California, July 14, 2006.

${ }^{127}$ Ronald W. Parshall, Private, Nike Electronic Equipment Repairman and Launcher Crew, Interview by Jessica Barrella, San Francisco, California, July 14, 2006. 
young with a tremendous amount of responsibility. They felt that "the call of WWIII may come to them," former Nike Target Tracking Radar Supervisor Ezio Nurisio remembered. "The general feeling was that they were possible targets since they were protecting targets." Former Alternate Battery Acquisition Radar (ABAR), Al Kellogg, recalled that their biggest fear was running out of missiles-not dying. They were trained to only think about completing the job. Indeed, they were trained so thoroughly and regularly, they never thought about failing the task, nor did they question being successful if confronted with an attack. ${ }^{128}$

The introduction of the Nike Hercules to the San Francisco Bay Area occurred with little fanfare. This may have been because the Army was reluctant to inform residents that nuclear tipped missiles were nearby. The Army announced in Congressional testimony that "it did not disclose at which sites the nuclear rockets were placed because of security reasons." This secrecy was also prevalent on base: nuclear tipped missiles were "Need to Know" information. The Hercules missile could be fitted with a conventional or nuclear warhead. For this reason their placement was released to the public, but which warhead it had and at what location was confidential:

The Army received no complaints from the public over the storage of Nike-Hercules missiles in metropolitan areas. But although the public had been told the missiles were stored in urban areas and that they were capable of carrying nuclear or conventional warheads, "in the interests of

\footnotetext{
${ }^{128}$ Al Kellogg, SPC4, ABAR (Alternate Battery Acquisition Radar) Electronic CounterCounter Measure, Nike Missile System, C Battery, 2nd, 51st Artillery, San Rafael, CA, and former Nike Missileman, Interview by Jessica Barrella, San Francisco, California, July 16, 2006.
} 
security . the exact location of Hercules warheads has not been disclosed." $" 129$

When Fort Barry/ Sausalito received its Hercules missiles, it was reported that the new missile "could outspeed, outclimb, and outfly (sic) any plane in the world." But the emphasis of the article was on safety. "An accidental explosion or firing of one of the missiles was virtually impossible," it was reported. Residents were told that open houses were not going to be available for Hercules launching areas. Visitors were discouraged with the increased security of double fencing and German shepherds guarding the area. ${ }^{130}$

Despite safety precautions, an accidental explosion did occur in May 1958 at Middletown, New Jersey, killing ten men. This and the inter-service missile rivalry (pitting the Army against the Air Force) challenged the Army to "bolster the program's image." 131 What resulted was "Operation Grassroots," initiated in San Francisco. On July 23, 1959, The Fairmont Hotel's lobby was transformed into a "mock Nike command center" with a Nike poised outside the hotel. The exhibit was open to the public and

129 "Army Reveals Atomic Missiles Already Are In Place Near Cities," Newspaper Unknown, Undated, From the Personal Collection of Ronald W. Parshall.

130 Orr Kelly, "Nike-Hercules Missiles: Bay Defense Post Get Killer Rockets," Newspaper Unknown, Undated; Bob Campbell, "New Bay Guardians," Newspaper Unknown, Undated, From the Personal Collection of Ron Parshall.

${ }^{131}$ President Eisenhower also voiced his concern regarding the inter-service problems of the Nike. He feared that voicing criticisms of the missile would "alert the enemy" and "haring the confidence of the public." Memorandum of a Conference with the President, White House, Washington, May 24, 1956, FRUS, 1955-1957, vol. XIX: Foreign Relations: 311-315.

Anxious to stop Army Anti-Ballistic Missile development, in the Spring of 1956, the Air Force launched an aggressive public relations campaign charging that the Army's Ajax and soon-to-be-deployed Nike Hercules were unfit to guard the nation." Lonnquest and Winkler, vol. I, p. 108. 
attracted thousands. "Encouraged by the positive public response," the U.S. Air Defense Command expanded the exhibit to a national program. "Soon Americans attending state fairs and other public gatherings could watch demonstrations of the Nike antiaircraft missile system in action." 132 The Nike had become a patriotic symbol of which Americans could be proud.

The Nike missile system, although effective only for a short time, was active for about 20 years. First deployed as the Ajax in 1954, it was created when aerial bombers were the primary threat to American cities. The vulnerability of cities was especially apparent in San Francisco, California, where twelve missile batteries protected the city. On either side of the metropolis regular atomic and thermonuclear testing was taking place. Residents felt particularly susceptible to attack as they watched, heard, and felt detonations, practiced civil defense drills, and were warned about Soviet assault off the coast.

The Nike-Ajax was only deployed three years before the Soviet Union launched an artificial satellite, demonstrating intercontinental ballistic missile capability. It was not until the following year, in 1958, however, that the nuclear tipped Nike Hercules was deployed. Although designed to augment the deficiencies of the Nike-Ajax, in the age of the ICBM, it was apparent that anti-ballistic missiles were needed to defend against the new means of attack. Although little mentioned and not always seen, the Nike missile served its purpose to protect American cities during the years of its deployment, and its placement within and around cities changed the American Cold War landscape.

132 Ibid. p. 99. 


\section{Chapter 5}

\section{Power for Peace:}

\section{The Transformation of Cape Canaveral, Florida}

What oil did for Texas, the automobile for Michigan, the cow for Illinois, the aircraft for California, the missile is about to do for-and to-Florida. It's only going to be about as fast and sensational as the rockets that are causing it all. ${ }^{1}$

In 1950 Cape Canaveral, Florida, was designated the first station of the Atlantic Missile Range and within a decade became the epicenter of the space program. The importance placed on missile development and space exploration at the Cape greatly impacted neighboring communities. Cocoa and Titusville Both welcomed the missile test range. The increasing importance of the missile accelerated area growth and hurtled Brevard County into the international spotlight. Much of the technological innovation of missiles was tested right at the Cape, providing its neighbors with a first-hand look at the future. There were two faces of the missile: the public relations side which was carefully controlled and released by the government to the press, and the local experience which allowed nearby residents of Cocoa and Titusville to be personally involved in the missile development process. In their own way, residents participated in missile development. By embracing both the Air Force and later the National Aeronautics and Space Administration (NASA), they were able to witness missile test flights and space launches and provide a community environment for all personnel based at the Cape.

1 "Whole of Florida to Benefit by Moon Launch," The Cocoa Tribune, July 16, 1962, p. $1 B$. 
Cape Canaveral is situated off the peninsula of Merritt Island half way between Miami and Jacksonville, Florida, and bordered by the Banana River on the west and the Atlantic Ocean on the east. The location was long known as a place of leisure and "natural enchantment" with abundant fishing and beautiful beaches. The selection of the Cape as the first launch site for the Long Range Proving Ground on May 16, 1950, immediately impacted local residents. A United States district court order signed by Federal Judge William J. Baker of Tampa "gave the federal government the right of immediate possession" of about ten square miles of land. Landowners were promised a "fair and just price for the property being taken," but many residents did not feel that they were adequately compensated. ${ }^{2}$ Within a month the government began to use eminent domain to forcefully remove some residents off the Cape.

Concern for the unjust treatment of those asked to vacate their property was voiced in a local paper, Titusville Star-Advocate. Several situations were cited as examples of unjust government action. A widow with four children living in a five-room home on twenty-three acres close to the river was "forced to vacate and seek another home with \$2800." An elderly couple living in another five-room house "on a paved road close to the ocean" was given $\$ 3300$. "Two lots costing $\$ 400$ less than two years ago, [were now only] worth $\$ 50 \ldots$ One subdivision on paved road close to the ocean" was

\footnotetext{
2 "U.S. Is Given Use of Canaveral by Area Judge: Condemnation Suit is Now on Federal Court Docket," Titusville Star-Advocate, April 21, 1950, p. 1. The Florida State census of 1945 gave a total of 72 people living in the area, but the estimate was changed to 150 people. Others may be partial owners.
} 
valued at about $\$ 10$ each. "Land prices range from $\$ 12$ to $\$ 25$ per acre on road close to ocean or river." Appraisals of the land could not include sentimental value. ${ }^{3}$

The low value that the government placed on land was most problematic for those trying to relocate. "If someone will come forward and tell us where we can relocate ourselves on any land between a river and the ocean anywhere on the East Coast of Florida at such ridiculous prices we will thank you and we will relocate there." The letter closed by noting that residents never believed the government would "conceive of such a thing [as to] swindle us out of our property, which is a shame and an outrage." ${ }^{.4}$ Many residents also did not receive immediate payment from the government to make their move possible. "A number of complaints" by those who were bring forced to leave the area by July but had not received payment for were directed to Senator Spessard Holland (D), who tried to assure residents of government compliance.

General William I. Richardson, commanding officer of the proving grounds, declared that the first guided missile would be launched from Cape Canaveral on July

${ }^{3}$ One resident noted special gardens and where fruit trees were located, and the famous Cape Canaveral Pier "which has been used by Fischer fish and shrimp fleet for years, had been closed to the public for fishing and commercial operations and will cease by the end of [July]." "Guided Missile to be Launched Early Tomorrow: Airport Here Will be Closed between 7:30 and 8:10 A.M." Titusville Star-Advocate, July 18, 1950, p. 1. An editorial commented that the closing of the pier was unfortunate, "but no more unfortunate than that of the many families who had been forced to give up their homes in the area and re-establish themselves elsewhere. War hasn't changed since Sherman pronounced his definition of it." "Pier at Cape Canaveral Closed," Editorial, Titusville Star-Advocate, July 18, 1950, p. 2.

${ }^{4}$ Canaveral Resident, "Calls It Injustice," Letters From Our Readers, Titusville StarAdvocate, May 23, 1950, p. 2. 
19th, "just four days after the resident evacuation was suppose to be complete." Immediately the landscape changed: a danger area extending from Cape Canaveral to 225 miles "in a north-northeasterly direction to a point of about 150 miles from Fernandina" was declared. Anyone who had not yet vacated the area would be in jeopardy. ${ }^{6}$ The first missile to be launched from the LRPG was designated Bumper no. 8, a modified German V-2 rocket. Resident association to the Cape would be forever changed: the area would no longer be known for its natural enchantments. Gone were the days of plentiful fishing, beautiful beaches, and small, secluded homes. Instead, Bumper's firing “brought Brevard County and Cocoa in particular to nationwide attention as newspapers, magazines and the radio" featured the first missile firing. ${ }^{7}$ The quiet central-eastern seaboard of Florida was on its way to being at the forefront of the Cold War. From the first launch, Titusville and Cocoa (the Cape's neighboring cities and both located on the main land) would be impacted by the rising importance of missile technology.

Cape Canaveral had become the location of the Air Force Missile Test Center (AFMTC), and in 1951, it was selected as the first tracking station of the Atlantic Missile Range (AMR), with Patrick Air Force Base (PAFB) designated as its formal

5 "Canaveral Residents To Be Paid Soon; $1^{\text {st }}$ Missile to go July $19^{\text {th }}$," Titusville StarAdvocate, June 27,1950 , p. 1 . The actually launch date was July 24 , after several days of complications. It drew national attention and was considered a success. "Missile Doesn't Miss; Heads Out to Sea Yesterday," Titusville-Star Advocate, July 25, 1950, p. 1.

6 "Danger Area Named for Firing of $1^{\text {st }}$ Guided Missile," Titusville Star-Advocate, July 11, 1950, p. 1.

7 "Second Guided Missile Due to Fly Tomorrow," Titusville-Star Advocate, July 28, 1950, p. 1. 
headquarters. ${ }^{8}$ Within four years the test range had finalized plans to extend to the islands of St. Lucia in the West Indies and Ascension in the South Atlantic-elongating the AMR to five thousand miles. ${ }^{9}$ The creation of the AFMTC was part of the Air Research and Development Command and its purpose was to test, collect data, evaluate performance, and provide training for and on various types of missiles for both the United States and its allies. The Air Force, Time described to readers, "was a scientific army never at peace. . . . Its weapons are drawing boards, wind tunnels, computers, rockets and vacuum tubes." ${ }^{10}$ The technological innovations of the Air Force would provide nearby residents with the first glimpses of "push button" remote control weapons as test missiles were launched from the AMR, making them feel intimately involved in the missile development process. ${ }^{11}$

${ }^{8}$ The history of the LRPG can be traced back to World War II, when it was built as the Banana River Naval Air Station. It deactivated on September 1, 1948 and transferred to the Air Force thirteen months later. It became reactivated and renamed as the LRPG. Clifton A. McClelland, ed. "Operations Analysis Working Paper 58-6 Brevard County Socio-Economic Population, 1950-1958," KSC Archives, Brevard County Economic Impact, Box 38A.4, Folder 2. The base was named after Major General Mason Patrick, the first Chief of Army Air Service.

${ }^{9}$ Air Force Missile Test Center, Booklet for visiting personnel, Undated. KSC Archives, Missiles, Box 30B.2, Folder 11. The AFMTC was connected by submarine cable as far south as Puerto Rico to collect data.

10 "Pioneers in Space-Air Force Scientists Face the Unknown," Time, December 19, 1955 , pp. $72-77$.

11 Confusion with different names and the difference between installations and organizations was prevalent because they were incorrectly used interchangeably. Users failed to "distinguish between an installation, an organization, a geographical area, and a group of facilities." In 1965, the Library of Congress asked for clarification so that information concerning the sites could be listed. "Brief Explanation of the Origin and Lineage of the Following Entities," KSC Archives, Missiles, Box 30A.6, Folder 2. 
Public reception to the designation of the Cape as a missile proving ground and as the first station of the Atlantic Missile Range was positive in both Titusville and Cocoa. ${ }^{12}$ Both predicted the announcement would bring an increase in employment and revenue, but each city welcomed the missile testing facility differently. Cocoa embraced the Air Force and invited its men to their churches and community functions and were more involved in the personal lives of the men: Titusville primarily foresaw the economic impact it would have on the area and focused its relationship with the base in that way. ${ }^{13}$

The relationship of each city to the AFMTC is also reflected in an information guide for visiting personnel. In it Cocoa was described as a great place to shop, fish, and sunbathe, making it an excellent location to live and visit. Along with its seventeen churches were an "ever expanding shopping area" and a "nationally famous restaurant." Cocoa also had good public transportation: the Florida East Coast Railway and Greyhound Bus Lines made the city accessible to both visitors and residents. Titusville, while it is good for fishing and golfing, was mentioned primarily as a citrus center and the seat of Brevard County. ${ }^{14}$

Public relations of the Air Force Missile Test Center were an integral part of its image with its neighbors. As one of the AFMTC's guide books mentions, "base and local activities are closely dovetailed, perhaps to a far greater degree than might be found at the

\footnotetext{
${ }^{12}$ Neither city was cleared of its residents.

${ }^{13}$ The Cocoa Merchants joined forces with the USO to provide free baby-sitting services for the military and civilian personnel so they could shop. "Gee Mom This Service is Terrific!” Advertisement, The Cocoa Tribune, August 20, 1954, p. 3.

${ }^{14}$ Air Force Missile Test Center, undated, KSC Archives, Missiles, Box 30B.2, Folder 11.
} 
typical Air Force Base.”"15 This feeling of camaraderie was reflected in a speech given before the Cocoa Retail Merchants Association by the AFMTC public relations officer. He commented on the base's relationship with the city and noted that the men stationed there "had found a great deal of friendship at Cocoa. . . took part in community affairs, and attended the Cocoa churches." ${ }^{\prime 6}$ Several years later, Cocoa Beach celebrated their relationship with PAFB by hosting "Air Force Night" which highlighted the "closeness of the two communities." The event was sponsored by several local civic organizations such as the Kiwanis, Jaycees, Chamber of Commerce, and Rotary Club. ${ }^{17}$ Cocoa's relationship to the AFMTC was neighborly. Residents embraced and welcomed those associated with the base. As an article about Cocoa Beach commented, "the locals obviously are proud of their association with their governmental neighbors." $" 18$

To show their gratitude Patrick Air Force Base often held open house events-but the most popular occasion was Armed Forces Day. The theme for the 1954 PAFB Armed Forces Day Open House was "Power for Peace" and it became a phrase that

${ }^{15}$ Missileland Communities Present: 1963 Guide to Patrick Air Force Base Florida, KSC Archives, Missiles, Box 30A.4, Folder 6.

16 "Pelle Explains Civilian Control of Missile Range," The Cocoa Tribune, February 2, 1954, p. 1. A month later a member of the base was a guest speaker at the local chapter of Daughters of the American Revolution (DAR). The chapter felt that it was fortunate they were located "so near [to] the Test Center." "Major Pelle Tells Members of D.A.R. Chapter Development of Guided Missiles at AFMTC," The Cocoa Tribune, March 26, 1954, p. 4.

17 "Citizens, Military Hail Banquet Honoring Our Air Force Neighbors," The Cocoa Tribune, September 20, 1961, p. 1.

${ }^{18}$ Robert G. Whalen, "Visit to the Three Cape Kennedys," New York Times Magazine, December 13, 1964, KSC Archives, Brevard County Economic Impact, Box 38A.4, Folder 2. 
would embody the missile. It was a big event for Cocoa and was mentioned regularly in their local paper, The Cocoa Tribune, for weeks leading up to the event. As a public service the newspaper announced the Open House in a full-page advertisement. ${ }^{19}$ The event had drawn large crowds since it began in 1949, but a much larger crowd was anticipated in 1954 (about 10,000 spectators) because of missile launchings demonstrations and bomber squadron displays. ${ }^{20}$ Two years later, the Armed Forces Day crowd of PAFB more than doubled, and rather than viewing missiles as destructive weapons, spectators were enjoying the technological display.

Armed Forces Day was a national event and local residents of the Cape felt special. Observing new weapons was not limited to one day a year. Residents were able to see missiles in action as they were regularly tested in their own back yard. ${ }^{21}$ They did not appear to be concerned with the possible danger of missiles as weapons, but instead embraced its image to distinguish their portion of the country from other American cities. Consequently, the missile became a part of resident culture.

19 "A Salute to Armed Forces Day," The Cocoa Tribune, May 14, 1954, p. 6.

20 "PAFB Planning An Open House for Armed Forces Day May 16 ${ }^{\text {th }}$, The Cocoa Tribune, March 30, 1954, p. 1; Patrick to Hold Open House Sunday 1 to 5 P.M.," The Cocoa Tribune, May 14, 1954, p. 1. PAFB kept the slogan Power for Peace and continued to use it in future Armed Forces Day programs and in their guidebooks. Armed Forces Day May 20, 21, 1961 Official Program, KSC Archives, Richard A. Sweetsir Collection, Box 17A.7, Folder 47b; Missileland Communities Present: 1963 Guide to Patrick Air Force Base Florida, KSC Archives, Missiles, Box 30A.4, Folder 6.

${ }^{21}$ In 1956, 0ver 22,000 people came to the AFMTC at PAFB. In 1957, the BOMARC was shown publicly for the first time. "New Missile Will Be Shown," The Cocoa Tribune, May 17, 1957, p. 1. A Titian missile was on display during Armed Forces Day at PAFB in 1959. Photograph, Titusville Star-Advocate, May 13, 1959, p. 1. 
Many local businesses incorporated the symbol of the missile in their advertisements. Central Brevard National Bank announced the grand opening of a new bank branch with a picture of a missile, advertising "Another Launching in Cocoa." The ad also linked itself to the future by telling potential customers it was "a progressive bank for a growing area, ${ }^{, 2}$ When the Merritt Island Shopping center opened it ran an advertisement in the shape of a missile with a countdown to its grand opening, and when Publix, the local supermarket, opened its doors on Satellite Beach, it promised "Space Age pleasure for shoppers." ${ }^{23}$ Around the country, the missile was increasingly viewed negatively: it was a weapon that used instantaneous push-button technology and it increased the possibility for catastrophic accidents. In the area surrounding the Cape, the missile was viewed in a more positive light: it was associated with the future and the good things technology would bring.

Missiles became symbolic to locals and visitors alike. Miss Satellite of the Beach Community Fund Raiser posed on a Snark missile on the front page of The Cocoa Tribune, and Brevard County students participated in a judged missile model competition sponsored by the Atlantic Missile Range Public Relations Association. ${ }^{24}$ Cocoa's

22 "Grand Opening! Central Brevard national Bank of Cocoa," Advertisement, The Cocoa Tribune, February 15, 1957.

23 “6...5...4...3..2.1 Grand Opening," Advertisement, The Cocoa Tribune, May 22, 1962, p. 9; "Space Age Pleasure for Shoppers," Advertisement, The Cocoa Tribune, September 22,1962, p. 3B.

24 "You May See This on the Cover of Life Magazine," The Cocoa Tribune, July 3, 1957, p. 1; "Missile Models Judged at Air Force Test Center," The Cocoa Tribune, May 11, 1961, p. 1. Models were built to scale. 
association with the missile was officially announced to visitors with the construction of the "Missileland U.S.A." sign erected north and south of city limits. The Cocoa Jaycees converted "surplus bombs" donated by Stanford Naval Air Station, into the "missiles" used in the sign. ${ }^{25}$ The missile's association to Cocoa was complete when in July 1961 five Miss Universe contestants accompanied by Jayne Meadows visited the area. The contestants told reporters they'd rather "miss a chance to talk with movie scouts" or be late for the Miss Universe Ball than miss an opportunity to see "a real honest-to-goodness missile. ${ }^{26}$ Cocoa residents were clearly proud of their social connection to their missile neighbors, but the fiscal benefits of such a partnership slowly evolved.

The growth of the first stepping-stone of the Atlantic Guided Missile Range had social and cultural implications to the local economy. ${ }^{27}$ Cocoa's emphasis on the economic aspects however, become more pronounced when the missile program at Cape

25 "More 'Missiles' for Project," The Cocoa Tribune, June 12, 1961, p. 4. A few years later, Boeing erected a sign on southbound U.S. 1, a road along the coast that connects coastal cities and provides access to the Cape, which advertised its connection to "three important weapons and the space program." The sign featured the Minuteman ICBM. "Boeing Sign on U.S. 1 Boosts Area, Canaveral Missile Program," The Cocoa Tribune, October 29, 1962, p. 2.

26 "Missiles Were Stars for Beauty Queens," The Cocoa Tribune, July 17, 1961, p. 1. The contestants were late to their event by over an hour.

${ }^{27}$ The ability of the commander of the AFMTC to talk simultaneously with five other commanders at down-range stations as a result of submarine cable was seen as a technological marvel that could impact the local community. "Air Force Missile Test Center Here Now has Direct Phone Connections with All of Down Range Stations," The Cocoa Tribune, May 7, 1954, p. 1; "World's Longest Radar Tracking System nearing Finish," The Cocoa Tribune, February 28, 1956, p. 1; "Complete History of Patrick Air force Base is Published," The cocoa Tribune, October 4, 1957, p. 1; "Bahama Outpost Gathers Important Missile Data," The Cocoa Tribune, June 28, 1961, p. 6. 
Canaveral shifted emphasis from weapons to space exploration in the early 1960s. When President John F. Kennedy sped up missile development to close the missile gap, business increased for the area. Over a two-year period, sixty-two new stores were opened and shop vacancy decreased by two-thirds in Cocoa. This was accredited to the AFMTC spending more than fifty percent of its $\$ 276$ million budget in Brevard County. Increased spending also was attributed to decreased unemployment. ${ }^{28}$ Brevard County growth quickly caught up with its residents, however, and was reflected in housing and school shortages, public utility problems, and traffic congestion. ${ }^{29}$

Titusville, although just as welcoming as Cocoa, foresaw the Air Force Missile Test Center as an economic opportunity from its onset. As early as 1952, the economic impact that the AFMTC would have on the city was evident when the Naval Air Base Command headquartered at Jacksonville submitted a lease for the "occupancy and use by the government of the Titusville-Cocoa Municipal Airport." 30 Government allocation of money to the AFMTC and PAFB was seen as a benefit to all nearby residents of Cape

${ }^{28}$ Doug Bederer, "Survey Reveals 314 Businesses in Cocoa Beach," The Cocoa Tribune, August 10, 1961, p. 1; Karl Hunziker, "AFMTC Spent 267 Million in '61, Half in Brevard," The Cocoa Tribune, August 21, 1961, p. 1; "Central Brevard Employment is Best in History," The Cocoa Tribune, July 5, 1962, p. 1.

29 "Brevard's Growing Pains Graphically Spelled Out," The Cocoa Tribune, November 16, 1962, p. 1.

30 "Lease for Titusville Cocoa Airport Approved by Navy," Titusville Star-Advocate, March 4, 1952, p. 1. 
Canaveral. It created job growth and aided in the improvement of local facilities. ${ }^{31}$ Enthusiasm was expressed in the summer of 1953 when bidding began for construction at the AFMTC. "Local residents greeted the news ... with great satisfaction," the Titusville Star-Advocate noted. "Most local residents and businessmen believe that the work will bring many construction personnel to the area and will mean much to the future of the North and Central Brevard area." ${ }^{, 32}$ An editorial noted the local benefits of the increased Air Force Budget at a time of Department of Defense reductions. "Of special interest to the people of Titusville and Brevard County" was the announcement by the Department of Defense to "drive to produce more ballistic missiles" in a time when defense expenditures were being "curtailed." This news was especially noteworthy to residents because "much of the final experimental work and particularly all of the actual flight testing of these missiles is taking place at Cape Canaveral-fifteen miles from this community." ${ }^{, 3}$ The accelerated missile program was interpreted as the nation preparing for war; in the area surrounding the Cape, the missile program was celebrated as an economic opportunity.

The relationship between Titusville and the AFMTC was commemorated in 1957 when the local Jaycees honored "all personnel connected in any capacity with the test

31 "Workers Now Using A1A to Travel to Base," Titusville Star-Advocate, April 15, 1952, p. 1; "Missile Funds go to Work on New Stations," Titusville Star-Advocate, July 14, 1953, p. 1.

32 "Army Opens Bid for Buildings at Canaveral: Titusville Residents Believe Test Center Work to Aid this Area," Titusville Star-Advocate, July 17, 1953, p. 1; "New Construction and Its Benefits," Editorial, Titusville Star-Advocate, July 17, 1953, p. 2.

33 "No Cut in Missile Testing Program," Editorial, Titusville Star-Advocate, August 16, 1957, p. 2. 
center and the Air Force Base in appreciation of their coming to Brevard County and to show that local residents and businessmen are grateful for their being here." In preparation for "Missile Appreciation Day," the Titusville Star-Advocate distributed a special issue. "Throughout the Missile Test Center" advertised exclusive retail sales as a courtesy to local merchants, and local businesses "stocked their shelves accordingly." The event was a noted success with attendance of seven to eight thousand people. ${ }^{34}$

Like Cocoa Beach, Titusville associated itself with the image of the missile and futuristic technology with the erection of two signs in the late 1950s. "Welcome to Titusville - The Missile City" was placed on US-1 and featured "a flash fire coming from the bottom of the missile . . . which gives it the appearance of beginning its 'take-off' from a launching pad." Citizens thought this sign differentiated their city from other nearby coastal cities because of its four-stage rocket and modern neon light display. ${ }^{35} \mathrm{~A}$ year later several more signs associating the city to missile development were placed along US-1 and near the causeway road leading to Cape Canaveral. With a missile ready for launch, the signs proudly announced, "You're in Titusville Overlooking Cape

\footnotetext{
34 “ 'Missile Employee Appreciation Day' Planned,” Titusville Star-Advocate, April 5, 1957, p. 1; "Jaycees Take Lead in 'Missile Day' Sunday," Titusville Star-Advocate, May 3, 1957, p. 1; "Merchants Are Cooperating with Week-End Sales Promotion," Titusville Star-Advocate, May 3, 1957, p. 1; "7,000 Attend missile Employee Appreciation Day," Titusville Star-Advocate, May 7, 1957, p. 1.

${ }^{35}$ Photograph, "Letting Them Know," Titusville Star-Advocate, May 20, 1959, p. 1. The Chamber of Commerce sponsored several signs indicating the distance from Titusville letting motorist know they were approaching the city. "Novel Highway Sign Now Advertises 'Missile City,"” Titusville Star-Advocate, March 28, 1958, p. 1.
} 
Canaveral." ${ }^{36}$ This connection would continue as local businesses and housing communities incorporated the words "missile" and "satellite" into their titles. ${ }^{37}$

By the end of the decade, there was no mistaking the economic impact that the AFMTC had on the northeast coast Florida economy. Russell Dixon, manager of the Florida State Employment services, explained in the beginning of 1958:

The civilian economy in the Cocoa-Melbourne-Titusville area is directly geared to that of the AFMTC, 'Every time a man leaves a job in town to take one at the base, he had to have a replacement,' he said. 'I've watched it over the years and it holds true that twice the number of jobs are created by the people that work in the missile program. We have 28,000 people in the county whose jobs were created through the AFMTC with its 14,000 workers. That includes new industry. It works out two to one. ${ }^{38}$

Dixon's math is wrong, but his point is clear: the AFMTC created an unprecedented amount of job opportunities in the community. Between 1950 and 1958, Brevard County was the fastest growing county in Florida, with a population increase of over three hundred percent. The missile industry "overshadowed all others in the county" because of its size and growth, and the payroll of the AFMTC was the county's "largest source of income." 39 Employment at the Cape had grown from one thousand in 1950 to an

${ }^{36}$ Photograph, Titusville Star-Advocate, April 15, 1959, p. 1.

37 "Satellite Center Inc. Construction," Advertisement, Titusville Star-Advocate, June 17, 1958, p. 3; "Missile View Homes," Advertisement, Titusville Star-Advocate, August 15, 1958, p. 3.

38 “Area's Biggest Boom is Seen in Congress Plan to Step Up Missiles," The Cocoa Tribune, January 13, 1958, p. 1.

39 "Brevard County Socio-Economic-Population 1950-1958," KSC Archives, Brevard County Economic Impact, Box 38A.4, Folder 2. The 1950 Titusville Census counted 
estimated 27,000 in $1960{ }^{40}$ By this time, however, the Soviet Union put the first artificial satellite into orbit, shifting the emphasis of the mission of the AFMTC from testing missiles for national defense to space exploration. This catapulted Cape Canaveral to international prestige - and the area became a travel destination. ${ }^{41}$

As discussed in Chapter 1, in 1955 the United States had announced that under sponsorship of the National Academy of Sciences and the National Science Foundation it intended to send a satellite into orbit during the International Geophysical Year (IGY) of 1958, but there was little apparent "rush" to do so. At that time there was no perceived "race" with the Soviet Union. Many in the White House did not believe that the Soviet Union had the technological know-how to design, build, and successfully launch a ballistic missile into space with enough thrust to support a satellite. American scientists, on the other hand, were not so assured and repeatedly warned government officials not to underestimate Soviet scientists. When Sputnik was launched on October 4, 1957, both the

4,223 residents and the June 1958 population was estimated at 17,000. The Cocoa numbers were 4,245 and 18,000 respectably.

${ }^{40}$ The 1950 payroll "amounted to about two million dollars" and climbed to 130 million in 1960- "some sixty-five times the 1950 outlay." "The Effect of the Atlantic Missile Range on Land, Highways, and Utility Systems in the vicinity of Cape Canaveral, Florida," Prepared for NASA by East Central Florida Regional Planning Council, KSC Archives, Brevard County Economic Impact, Box 38A.5, no Folder.

${ }^{41}$ It was concluded that whom ever controlled space would control earth. Khrushchev made it a point for the Soviet Union to continue to outpace the United States in space achievements. Sergei N. Khrushchev, Nikita Khrushchev and the Creation of a Superpower (University Park, Pennsylvania, 2000), p. 357. 
American public and its leaders were shocked. Indeed, it had extended the Cold War to space.

The launching of Sputnik stunned the nation and its allies, but most importantly for the Cape Canaveral area, it accelerated the missile program and initiated the Space Age. ${ }^{42}$ The National Aeronautics and Space Administration (NASA) would incorporate the already existent National Advisory Committee for Aeronautics (NACA) and "other programs and facilities from existing agencies, most notably the Army's Jet Propulsion Laboratory (JPL) and Redstone Arsenal at Huntsville, Alabama (now the Marshall Space Flight Center). ${ }^{, 43}$ For area residents, this was an exciting time. While most Americans were worried about missile development and the Soviet Union winning the missile race, residents of Titusville and Cocoa interpreted the formation of NASA as a bolster to their communities. The once remote missile sanctuary was put in the international spotlight and became the focal point of the Cold War race to space.

Space travel was not initiated to the Cape with the formation of NASA. Work

${ }^{42}$ Although the Soviets were first to launch a satellite into orbit with the use of an ICBM, they did not concentrate on stockpiling the weapon. Instead, they made the insinuation of a missile-gap, which in turn ultimately lead to the Cuban missile crisis. The space race, however, did not really begin until Kennedy made the declaration. Alan J. Levine, The Missile and the Space Race. (Westport, Connecticut, 1994).

${ }^{43}$ http://history.nasa.gov/naca/overview.html It was the threat of the ability of the ICBM that launched Sputnik into space that was the real threat to the Eisenhower administration, not the fact that the Soviets beat the Americans into space. But the president's reluctance to increase the budget and his inhibitions about a military-industrial-complex led to cautious decisions. Eisenhower did not believe that the Soviet Union wanted or could attack the United States. This belief further bolstered his reluctance to increase funding on R\&D and space technology. Alan J. Levine, The Missile and the Space Race. (Westport, Connecticut, 1994). 
begun on developing a satellite for launch during the IGY revealed that testing and development of ballistic missiles and space payloads overlapped. Space payloads had to be placed into orbit by an intercontinental ballistic missile. ${ }^{44}$ Thus, when the Soviets put Sputnik into orbit it was clear that they had developed both an artificial satellite and an ICBM. The United States-although it was not evident at the time - was not far behind the Russia. What made it appear so was the increased international attention and visibility of the many failures at Cape Canaveral. ${ }^{45}$ As the pressure mounted for a successful American launch, public interest in the new technology intensified.

Well before the Soviet success there was speculation about the use of the AFMTC at Cape Canaveral for the location of the IGY satellite launch. Willy Ley, German scientist and missile author, "guessed" that the launch would be from the Cape because it was near water (for safety reasons) and already established as a test site. ${ }^{46}$ Ley's "guess"

${ }^{44}$ During the summer and fall of 1957 , the press reported about missiles being tested for both national defense and the satellite launch. "Launching Rocket Test at Cape Canaveral, Titusville Star-Advocate, May 3, 1957, p. 1; "Two Large Missiles Reported Fired from Cape Test Center Wednesday," Titusville Star-Advocate, June 28, 1957, p. 3; "Thousands See Army's Jupiter in Night Test; Vanguard Still Awaited," The Cocoa Tribune, October 23, 1957, p. 1; "Vanguard, Thor Top Missile Tests," The Cocoa Tribune, October 25, 1957, p. 1.

45 "Missile Believed to be Atlas Spends Few Moments in Air," The Cocoa Tribune, September 27, 1957, p. 1. After waiting almost a week, a missile believed to be an Atlas flew into the air and quickly "crashed into the ocean." The unsuccessful launching "was viewed by many-newspapers, wireservice (sic) and magazine writers, and photographers and just plain ordinary people watching on their own time. . . Reporters and photographers have kept the cape Canaveral highway hot to last couple of weeks, hurrying to their ocean buff observation points "just in case." 'Ibid.

46 "Scientist Expects Canaveral to Send Up First Satellite," The Cocoa Tribune, August 16, 1955, p. 1; "First Space Satellite May be Launched from Canaveral Missile Base," Titusville Star-Advocate, August 16,1955, p. 1. There were concerns about the safety of 
was correct: by summer of 1956 , "Satellite Personnel" began to arrive. ${ }^{47}$ An American success was hailed before it happened: "When the first artificial satellite is hurled into space during the International Geophysical Year, the tiny globe-circling 'moon' will represent not only a gigantic step in the eventual conquest of space, but also a historymaking example of teamwork" by the Armed Forces, industry, scientists, technicians, and government officials. ${ }^{48}$ But secrecy surrounded the missile program. When two missiles were launched from the AFMTC mid-1957, the Air Force limited public information to only verification. Local "bird watchers" could only speculate about what missiles they were. One resident noted that its roar was louder than the Atlas and assumed the missiles were larger. ${ }^{49}$ Secrecy and the assurance that the IGY satellite would be the first in orbit

such a launch. Ley was asked about the possibility of "the satellite going in the wrong direction and hitting some Florida city such as St. Petersburg or Miami." The scientist responded that although it was possible, it was also unlikely because of a device that allowed an observer "to flip a switch and cut off the fuel." Ibid. Ley co-authored a book with fellow-German rocket scientist, Wernher von Braun. The Exploration of Mars. KSC Archives, Wernher von Braun, Box 3D.6, Folder 23.

47 "Satellite Personnel to Begin Arriving in Area July 1 $1^{\text {st }, " ~ T i t u s v i l l e ~ S t a r-A d v o c a t e, ~ M a y ~}$ 1,1956, p. 1. As with most articles concerning the Cape in the Star-Advocate, the focus of this story was its impact on the economy: in this case, housing.

48 "First Satellite will Represent Historical Teamwork Example," Titusville StarAdvocate, January 11, 1957, p. 8.

49 "Two Large Missiles Reported Fired from Cape Test Center Wednesday," Titusville Star-Advocate, June 28, 1957, p. 3. After the Soviet success, the perception that the United States was indeed behind became more apparent: each effort to launch the satellite Explorer ended in a very public failure. By the middle of October, the Department of Defense announced that it was "planning to strip away at least part of the secrecy surrounding the tests. . . . [which] would permit identification of rockets and some clues about its performance within security bounds." "Vanguard Launching Again Delayed at Canaveral," The Cocoa Tribune, October 21, 1957, p. 1. Before this announcement, 
aided to the shock of the Soviet success and led to the perception the IGY satellite program-and America's endeavor in the missile race-as a failure. ${ }^{50}$

Another very public disappointment occurred while Americans witnessed another Soviet satellite triumph. On December 6, barely two months after Sputnik I appeared at the missile test center the Vanguard missile used to launch an experimental satellite exploded on the launching pad creating a mushroom cloud "similar to the clouds that follow atomic bomb explosions." This disappointing event, according to the Titusville Star-Advocate, marked the end of the "first chapter in space history for the United States." The explosion was broadcast around the globe: "The eyes of the world were focused on Cape Canaveral today - as they have been for the past several days - but the results were not encouraging to Americans and to the free world."51 All hope was not

resident "bird watchers" guessed at what missiles were being launched and for what reasons. Later full reports were printed in local newspapers concerning companies that developed the missile, the name (or variation) of the missile, and its purpose were disclosed to the public. "Trio of Missiles Fired Past Nights Drew Attention," Titusville Star-Advocate, July 22, 1959, p. 1.

${ }^{50}$ To advance space exploration, Kennedy exploited American science inferiority-not differentiating between space exploration and advances in ICBMs. This tactic was similar to the one Khrushchev was promoting in the Soviet Union. Because of Kennedy's failure with the Bay of Pigs in Cuba, the space mission became paramount. Kennedy used his power as president to evoke an "aggressive lunar landing program." Kennedy's commitment to space captured the American imagination and attracted overwhelming support. Michael R. Beschloss, "Kennedy and the Decision to Go to the Moon," in Roger D. Launius and Howard E. McCurdy, eds. Spaceflight and the Myth Of Presidential Leadership. (Chicago, 1997).

51 "Pffht! First U.S. Baby Planet is earthbound as Vanguard Explodes on Launching Pad," Titusville Star-Advocate, December 6, 1957, p. 1. 
lost: the American missile arsenal was demonstrating early and unanticipated signs of success.

Increasingly newspaper articles focused on missiles, and it became clear that more information was being released to the public about the defense program. Although the United States had not launched a moon into orbit, the missile arsenal was growing. The mighty Atlas missile, the first American IBCM, had a successful trial flight accelerating production of the huge ninety-foot monster. In addition, two intermediate range ballistic missiles (IRBM) the Thor and Jupiter were advanced tested, with plans to be operational within a year. The Titan ICBM, still in the developmental stages (and predicted to be "more advanced" than the Atlas) was also ahead of schedule, and it was believed that the Navy's Polaris (an IRBM launched from a submerged submarine) would revolutionize the missile arsenal of the United States. ${ }^{52}$ Americans were hopeful that soon an American satellite would be in orbit, and public interest in missiles and the space program mounted.

Finally, or so it seemed, on January 31, 1958, Explorer I was put into orbit and carried with it far more in "prestige and honor and better days ahead." 53 By the end of March, two more U.S. satellites were circling the earth, making it "even-Steven" with the Soviet Union. ${ }^{54}$ The second successful satellite launch of March 17 and the anticipation of a third prompted one local newspaper to print a special section called "The Army-

52 "Now U.S., Too, Has Supermissiles," U.S. News and World Report, December 27, 1957, p. 31.

53 "1958-4 Years Ago-Explorer I Born, First of 68 U.S. Satellites to Date," The Cocoa Tribune, February 1, 1962, p. 1.

54 "Satellite Burns Up in Flight," The Cocoa Tribune, March 7, 1958, p. 1. 
Missiles, Rockets and Satellites." It showed pictures of various missiles, gave information about the Army missile program, satellites, and missilemen. It also gave advice to "amateur rocketeers." 55 The Titusville Star-Advocate reassured residents that despite many publicized failures, "there is no telling how many failures and disappointments Russia had with Sputnik I before the famous October day." ${ }^{, 56}$ Clearly the city was proud of the achievement and knew the world's eyes were on Cape Canaveral. ${ }^{57}$ Indeed, the Cape had come under the international spotlight. Americans were increasingly anxious to learn more about the space program and wanted to see a missile launch first-hand.

Three artificial moons in space not only put Cape Canaveral in the forefront of space history, but also space future: it gave the non-Communist world confidence that the United States would excel in space exploration by becoming the first country to put a man on the moon. A new race had begun and the failures were being taken in stride. ${ }^{58}$

55 "The Army-Missiles, Rockets and Satellites," Titusville Star-Advocate, March 18, 1958.

56 "Tempermental (sic) Vanguard Will Go Someday Soon," Titusville Star-Advocate, March 14, 1958, p. 2.

${ }^{57}$ The same day as the Vanguard launch, Titusville High School had its second annual Science Fair. Students demonstrated such enthusiasm in their projects that "judges had difficulty in selecting prize winners." First prize was awarded for a cold chamber "used to trap subatomic particles"; second prize was for a display of rocket cones and propellants; and third prize was for a digital computer design. In addition to the three prize-winners, there were five honorable mentions. "Science Fair has Many Unique Prize Exhibits," Titusville Star-Advocate, March 18, 1958.

58 "Shot at Moon Appears Next on Program as Three Free-World Satellites Are Circling Earth," The Cocoa Tribune, March 28, 1958, p. 1; “U.S. Pioneer Moon Rocket Blows Up 
Time referred to Cape Canaveral as Spaceport, U.S.A. in a dramatic article proudly reprinted in the Star-Advocate. With its prehistoric animals and desolate beaches, the secluded peninsula was introduced to outsiders as the city of the future:

The solo tune of an old-fashioned foghorn is overcome by the shriek of liquid oxygen as it pours under high pressure through valves and pipes. Clanging cords of hammer on steel, the humming sostenuto (sic) of machinery, the blip-blip rhythms bouncing onto radar screens from a network of grotesque antennas - the counterpoint races on in time to a thousand clocks, paced by thousands of hard-hatted men, their ears attuned, their hands ready on buttons, keys, switches, knobs, cranks and valves, their eyes darting from tube to dial, their pulses shooting over the unhurried step of time. And when the fire roar, the chorus of triumphant cries.

This is the rite of space that is performed day and night at the Air Force Missile Test Center at Cape Canaveral; the point from which the first U.S. man-possibly the first man in the world-will journey to the moon and beyond. Cape Canaveral is the U.S. Spaceport of the Future... ${ }^{59}$

Soon scientific equipment was being sent to orbit the moon. As one reporter noted, "The rocket shot to the moon early Saturday morning [October 12,1958$]$ has not only carried the science of astrophysics-even science itself-literally out of this world, it has also given the United States a 'first' of its own in the space age - a remarkable and significant achievement to follow closely on the first anniversary of Sputnik I." ${ }^{60}$ The United States had come a long way from its previous concerns and subsequent insecurities about Soviet scientific and technological superiority.

on Trial: Fuel Leaks in Thor Blamed; Shriever Hopeful of Future," The Cocoa Tribune, August 18, 1958, p. 1.

59 “'The Rite of Space and Spaceport, U.S.A. at Cape Canaveral," Time, reprinted in Titusville Star-Advocate, March 18, 1958, p. 1.

${ }^{60}$ Gene Burnett, "Rocket Launching Seen," Titusville Star-Advocate, October 17, 1958, p. 2. 
By summer, the Army was more freely-and rather proudly-releasing additional information about both its missiles and its involvement in the space program. Aviation Week explained to readers the connection between space flight and missile development. "Actually, it is impossible to separate missile or weapons work from space projects," readers were told, because the "technological problems for both are interlocked." The link between the two was evident when the Army proposed to send man into orbit "atop the Redstone missile."

The missile's link to the Space Age expanded the role of Cape Canaveral and made its jurisdiction stretch to California. To "better handle its rapidly expanding missile work" and meet the space challenge the Redstone Arsenal Complex was reorganized to the Army Ordinance Missile Command (AOMC) on March 31, 1958. The AOMC "was designed to exploit missile capabilities as fast and as fully as possible by placing all resources" under one commander, Major General John Medaris. The AOMC encompassed the Redstone arsenal, Army Ballistic Missile Agency, Army Rocket and Guided Missile Agency, White Sands Proving Ground, and Jet Propulsion Laboratory. ${ }^{61}$

As space exploration garnered support and became a national priority, the missile transitioned in the eyes of Americans from a weapon to a vehicle booster. The Explorer satellites demonstrate this connection: they were launched into space by a modified threestage Jupiter IRBM (Jupiter-C). The first stage (booster) was an Army Redstone ballistic

61 "Army's Mission is Space is Expanding," Aviation Week, reprinted by Redstone Arsenal, Alabama for AOMC Internal Information Release, KSC Archives, Missiles, Box 30B.2, Folder 3. 
missile. The upper stages were solid propelled variations of the Sergeant missile. ${ }^{62}$ Both the Jupiter-C and Vanguard were first generation "space carriers." The Atlas would be modified to an interim phase and a third generation carrier. ${ }^{63}$ By the beginning of the next decade, preliminary studies of rocket clusters were being done to create what would be known as the Saturn. ${ }^{64}$ Undeniably, it was the "cross-pollination of ideas" between missile development and space flight that stimulated the Space Age. ${ }^{65}$

1958 was designated the year of "space awakening for the nation," according to Missiles and Rockets magazine. ${ }^{66}$ By year's end, there were three ICBM and three IRBM projects, two agencies "calling the shots for outer space experiments, and a "space minded' Congress and national administration." The Atlas ICBM had several successful missions and appeared to be ahead of schedule, while the Titan, considered the "back-up ICBM" and the first missile designed to launch from a hardened site, was only one year behind the Atlas. Minuteman, a second generation ICBM using solid propellants, was already projected to be inexpensive to develop and deploy_- "one seventh the cost of the

62 "Teamwork for Space Power," AOMC Internal Information Release, KSC Archives, Missiles, Box 30B.2, Folder 3.

${ }^{63}$ The third generation consisted of the Centaur, Mercury, Able, and Athena.

${ }^{64}$ These launched the Score Satellite on December 18, 1958, "Big Joe" Mercury Capsule Test of September 9, 1959, and the Midas D Satellite on May 24, 1960. Clusters of both the Redstone and Jupiter missiles were tested. Wernher von Braun, "The United States Space Carrier Vehicle Program," KSC Archives, Wernher von Braun, Box 3D.6, Folder 9. Rocket clusters would be the method that the Soviet Union would eventually use to put men in space.

65 “Army's Mission is Space is Expanding."

${ }^{66}$ This was also the same year that James deer declared civil defense dead. See Chapter 2. 
Titan or Atlas." The Jupiter and Thor IRBMs had both achieved operational development, and the Navy's Polaris was demonstrating an "impressive flight record." In addition to a remarkable missile résumé, the United States achieved an equally impressive list of space experiments, which included sending three satellites into orbit and the successful recovery of a Jupiter missile nosecone. ${ }^{67}$ These accomplishments were revealed to the public when only a few short months ago Life had to "guess" about the functions of an ICBM. ${ }^{68}$ Missiles were popularized, and by the end of the following year Cape Canaveral was being marketed as a travel destination.

National Geographic intermingled science and poetry with technology and romance in its fifty-page feature article on the Cape. Photographs of scenic vistas intermingled with photos of technology and powerful missiles helped describe the small peninsula off the east coast of Florida as a land of beauty but also as a mysterious and exciting land of the future. The article described a missile launch as a "thin pencil of flame" trailing behind the rocket. the event was sublime in its beauty: "the racing flame shimmered an enormous tail of light, pearly, opalescent, for brief moments tingled faintly with green, a luminous veil miles long across the darkness and the stars." The splendor of

67 "1958 Was Year of Space Awakening for Nation," AOMC Internal Information Release, KSC Archives, Missiles, Box 30B.2, Folder 3. Nosecone recovery drills were done in preparation for retrieval of space modules.

${ }^{68}$ The magazine offered a "good guess on how intercontinental rockets worked," because information about missiles that were in production was so limited. A two-page illustration showed carefully rendered drawings of the Redstone, Corporal, Sergeant, Honest John, Hercules, Ajax, Lacrosse, Snark, Navaho, Bomarc, Matador, Rascal, and Falcon on one page. On the facing page are very simple shaded shapes of the Jupiter, Titan, Thor, Atlas, and Polaris - the very missiles that were raved about in Missiles and Rockets. "U.S. Missiles on Hand and In Works," Life, September 9, 1957, pp. 40-41. 
the event made observers feel like "men who had dreamed in color, while yet awake." Watching a missile launch into the magical heavens was poetic as "a ship sailing the phosphorescent sea," the article continued. ${ }^{69}$ Traveling south along the islands of the Atlantic Missile Range, the author described the primitive islands as "stepping stones toward the distant stars."70 Technology was humanized and made thrilling and acceptable - no longer shrouded in mystery and doubt. But as tensions between the Soviet Union and the United States heightened in 1961, Americans were reminded once more about the original function of the missile: to deter the enemy, and if necessary, wage war.

In contrast to the National Geographic, U.S. News and World Report reminded readers of the missile's original function by calling the Cape the "Missile Nest." The article focused on the missile's role in protecting the country: the "deadly array of U.S. war rockets ... [is] far more urgent" than the need for space flight." This was a story of national defense, technology, and deterrence. "Khrushchev's rocket rattling is what gives Canaveral new importance," readers were reminded. Compared to the National Geographic article, technological might is stressed over poetic beauty. "Under great arc lights by night and scorching sun by day, weapons ten stories high are brought in, assembled, fired in tests over the Atlantic. These days, a U.S. war missile thunders into the sky almost every working day." The article featured "the first panoramic view" of the missile firing line on the Cape, an imposing photograph of the succession of launch pads

69 "Cape Canaveral's 6,000-mile Shooting Gallery," National Geographic, 96 (October 1959): 421-471.

${ }^{70}$ Ibid. 
standing sentinel. The message was clear: Cape Canaveral had an "arsenal of "perfect weapons' to protect the nation." peace-and was publicized both ways, but its fascination remained.

By the middle of the decade, the focus of the missile had again shifted from a fierce weapon to a means of conquering the new frontier of space, and the world was again looking to the stars. Interest about missiles as launch vehicles reached a new plateau and seeing missiles and watching launches was no longer limited to residents of the Cape area. New York Times Magazine featured the Cape as a travel destination full of technological wonders among a very human community. "Cape Kennedy is not only a point of land jutting out into the sea. It is also a whole community whose very existence is the dawning of the space age." There were three "Cape Kennedys" (sic) according to the article: "the launch area, where the space story up to now has unfolded; the new area, where ground work for the space story of the future is being laid, and the community where the makers of both stories live." Technology and man were intertwined within this narrative of the Cape, but the real focus was on the future. ${ }^{72}$

One of the people most responsible for popularizing missile technology and making space exploration a reality was former German scientist and rocketeer Wernher von Braun. It was his team-primarily composed of German scientists - that developed the first American missile, the Redstone, which was later modified and used to launch the

\footnotetext{
71 "Inside the Missile Nest," U.S. News and World Report, September 4, 1961, pp. 60-61.

${ }^{72}$ Robert G. Whalen, "Visit to the Three Cape Kennedys," New York Times Magazine, December 13, 1964, KSC Archives, Brevard County Economic Impact, Box 38A.4, Folder 2.
} 
Explorer satellites into space. Inspired by the science fiction of Jules Verne, von Braun was a firm believer in space travel. In 1952 he referred to space as the "Last Frontier" in an article about rockets and space exploration written for Collier's magazine. ${ }^{73}$ A few years later he co-authored a book with fellow-German rocket scientist Willey Ley called The Exploration of Mars, and in 1962 he wrote about Mars exploration. ${ }^{74}$ Von Braun became a household name when he began working with Walt Disney by bringing the excitement of space exploration into the living rooms of America. ${ }^{75}$ Not only did he help demystify rockets and space travel but he also gained an eager audience among American youths. ${ }^{76}$ His enthusiasm for space exploration was contagious and contributed to the excitement surrounding conquering space. By 1960, science and space were brought to the home front: science was encouraged in school and had become a family activity. ${ }^{77}$

${ }^{73}$ Wernher von Braun, “Crossing the Last Frontier," Collier's, March 22, 1952, pp. 2429.

74 Wernher von Braun, The Mars Project, (Urbana, Illinois, 1962), KSC Archives, Wernher von Braun, Box 3D.6, Folder 22.

75 Michael Wright, "The Disney-Von Braun Collaboration and Its Influence on Space Exploration," a paper was presented at the 1993 Southern Humanities Conference entitled "Inner Space/Outer Space: Humanities, Technology and the Postmodern World." http://history.msfc.nasa.gov/vonbraun/disney_article.html

${ }^{76}$ Wernher von Braun received fan mail from "youngsters who want advice on how to become rocketeers." His advice was to "hit math and physics heavily." Ibid.

77 The Parent-Teachers Association (PTA) was a strong advocate for science education and space exploration in young children, beginning in 1958 with President Eisenhower's declaration of a renewed focus on science after the launching of Sputnik. Articles like "Science Makes the Grade" tell parents how to foster interest in science at home. Ralph H. Ojemann, "Science Makes the Grade," National Parent-Teacher: The PTA Magazine (September 1958): 15-17; Ellis W. Evers and Barbara Dawson, "Coming Right Up, Mr. Teller," National Parent-Teacher: The PTA Magazine (December 1958): 30-32; Irma 
This emphasis on science made Americans feel personally vested in the country's space ventures.

President Kennedy kindled the already present fears of threatened national security and the loss of American prestige to sell the Apollo Program. To do this, Kennedy used the narrative of the New Frontier-a theme begun by von Braun. The New Frontier thesis provoked the history of the American struggle as a form of Manifest Destiny to space. Placing space within this context helped Kennedy evoke romantic images with a sense of adventure. With the help of the media-especially a special contract with Life magazine - the rhetoric of the president and NASA successfully sold the idea of men on the moon to Congress and Americans alike. NASA's deputy administrator best summarized the feelings of the era when he said it was not important that a man land on the moon; it was the national effort to put him there "that was indispensable to the country's image.,"78

By the beginning of the new decade, the AFMTC started distributing pamphlets and booklets to visitors. Titusville High School printed a booklet entitled "From Here to Space: The Cape Canaveral Story" as an aid to make a "tour of the Cape more complete

Simonton Black and Betty Miles, "The Children's Hour: Space and Satellites," National Parent-Teacher: The PTA Magazine (May 1958): 12-14; Evelyn Millis Duvall, "Youth Prepares for the Scientific Age," National Parent-Teacher: The PTA Magazine (April 1959): 4-6; Andrew D. Holt, "Space-Age Parents," National Parent-Teacher: The PTA Magazine (September 1962): 4-6.

${ }^{78}$ James L. Kauffman, Selling Outer Space: Kennedy, the Media, and Funding for Project Apollo, 1961-1963 (Tuscaloosa, 1994), p. 21. 
and meaningful" to visitors. ${ }^{79}$ For Armed Forces Day that year, an official program was published which was filled with photographs of missiles as both weapons and space launch vehicles. ${ }^{80}$ Transparency of the missile program and interest in the space project stimulated. Consequently, higher exposure of these technological developments tightened security and limited access to the general public. ${ }^{81}$ But visitor information printed for distribution at the Cape (renamed Cape Kennedy after the president's assassination) became more detailed as America's space endeavors became a reality. Much of the information printed for visitors was geared toward the whole family with many close up pictures and artistic drawings, but most information was marketed toward younger children —and more noticeably boys. ${ }^{82}$

79 "From Here t Space: The Cape Canaveral Story," Booklet, May 1961, , KSC Archives, Richard Sweetsir Collection, Box 17A.7, Folder 47a.

80 “Armed Forces Day Official Program," AFMTC, May 20, 21, 1961, KSC Archives, Richard Sweetsir Collection, Box 17A.7, Folder 47b.

${ }^{81}$ One booklet published by the AFMTC apologized and explained to patrons the need for the heightened security of Cape Canaveral. "We wish that every American could visit Cape Canaveral, and that we could make favorable reply to the thousands of requests we receive every year." Because of cost, payroll, and security reasons, "visitors must be confined almost exclusively to officials with the need to know, and to newsmen who will share their experiences with the public through newspaper, magazine, radio and television. "Air Force Missile Test Center," Booklet, KSC Archives, Kennedy Space center, Box 30B.4, no Folder.

82 "Air Force Eastern Test Range," KSC Archives, Missiles, Box 30B.2, Folder 11; "Spaceport," KSC Archives, Press Kit Collection, Box 2F.2, Folder 60; "Welcome to Cape Kennedy Air Force Station," KSC Archives, Missiles, Box 30B.2, Folder 11. 
The pamphlet "I am a Missile Expert" was illustrated with cartoon-like drawings that described the basic workings of a missile and the fundamentals of space. ${ }^{83} \mathrm{~A}$ booklet printed by the United States Army Missile Command also had simple sketches accompanying explanations about the Army's role in missile and rocket development. ${ }^{84}$ Their straightforward explanations and illustrations make it obvious that their intended audience was children. The National Headquarters Civil Air Patrol at Ellington Air Force Base, Texas, printed a study guide about missile and rocket identification. Its straightforward definitions and more scientific layout were geared toward boys. The introduction page lists every missile to date and promises the student that after completing the exercises in the booklet it will be possible to identify missiles and rockets used in the U.S. defense and research programs. The identification process begins with a line drawing-or shaded silhouette-and a brief statement about the missile. Each description about the same missile is worded differently. The missiles and their characteristic are learned through repetition. After completing the fifteen-page booklet, the student would be able to identify the Redstone, Polaris, Minuteman, Atlas, NikeZeus, Pershing, Titan, and several other missiles. For the eager student, there were

83 "I am a Missile Expert," Pamphlet, undated, KSC Archives, Richard Sweetsir Collection, Box 17A.7, Folder 47b. In later years, when security was tightened and visitations to the Cape were limited, the ARMTC created a pamphlet to encourage tourists to visit the missile display designed for their pleasure. "Visit the Missile Display," Pamphlet, KSC Archives, Missiles, Box 30B.2, Folder 11.

84 "U.S. Army Missiles and Rockets," United states Army Missile Command, Redstone Arsenal, Alabama, KSC Archives, Missiles, Box 30B.3, Folder 8. 
follow-up pages to learn additional missiles. The booklet also came with a Certificate of Completion to be filled out with the student's name. ${ }^{85}$

Knowing the names and characteristics of missiles and also being able to identify them by shape was not unlike drills given to participants of the Ground Observer Corps during the early 1950s. One of the highlights for visitors of the Cape, however, was the actual missile display outside the Technical Laboratory building at Patrick Air Force Base. By August 1961, a Titan, Thor, Pershing, Matador, Snark, Bomarc, and Polaris were placed on "Missile Row." ${ }^{, 86}$ Young men did not limit their learning to rockets and missiles. They also envisioned a future that their parents never thought possible: the possibility of becoming rocketeers, missilemen, and astronauts.

1961 marked the year that the United States put a man into orbit—but again, it was after a Soviet success. On April 12, 1961, Yuri Gagarin became the first astronaut in history when he orbited the earth aboard Vostok I. Less than one month later, on May 5, hundreds of newsmen and photographers flocked to the Cape for the American inaugural flight. ${ }^{87}$ A Redstone missile launched Alan Shepard into a sub-orbital test flight for

85 "Rocket and Missile Identification: A Programed (sic) Learning Exercise," KSC Archives, Visitor Information Center Collection, Box 17B.3, Folder Missiles.

86 "Polaris Takes Place on Missile Row," The Cocoa Tribune, August 23, 1961, p. 6. In contrast to cape Canaveral. Most areas of PAFB were open to the public "without escort" and were able to be photographed. "Of Special interest is the display of missiles in front of the Technical Laboratory south of Patrick Air force Base on Route A1A. "Air Force Missile Test Center," Booklet, KSC Archives, Kennedy Space center, Box 30B.4, no Folder.

87 "Weather Key to Man-in-Space Launch at Cape," The Cocoa Tribune, May 1, 1961, p. 1. 
fifteen and one-half minutes. This event was intimate and emotional for Americans and especially for locals. As one Cocoa resident expressed, "Millions watched adoringly on television and cried openly. . . . The successful man-in-space flight of Friday was a national achievement and for once it was a case of national supremacy, of national accomplishment... There was part of all of us out there sitting in that capsule and flying through space." 88 The man-in-space program was in full throttle.

Scientists and technicians were racing against the clock to put a man into space by the close of the year. By November space flight at the Cape had taken precedence to the Thanksgiving and Christmas holidays. "Project Mercury officials have indicated privately that the history books will only record the year an astronaut was crowned and his nationality." For this reason, those associated with the space program felt personally responsible for an American success. An American space orbit had to be mentioned the same year as the Soviet success. The urgency placed upon workers required they be "available for a Christmas week launching." ${ }^{, 99}$ Although it took eleven attempts after that Christmas week to put an American into orbit around the earth, it was finally achieved on February 20, 1962.

John H. Glenn, a forty year old Marine Lieutenant Colonel, was the first American to travel around the earth—in fact, his orbit brought him around the earth three times. A modified Atlas ICBM (the Atlas-Mercury) launched Glenn into space, and his

${ }^{88}$ Douglas Morgan Dederer," Surfside Slant," Editorial, The Cocoa Tribune, May 8, 1961, p. 5.

89 “Holidays $2^{\text {nd }}$ Place to Mercury," The Cocoa Tribune, November 20, 1961, p. 1. 
flight lasted slightly under four and one-half hours. ${ }^{90}$ "Millions of Americans gathered before TV and radio sets. Many cheered; many preyed. It was a big moral boost for many who had watched postponement after postponement as this country attempted to get its first man into orbit." ${ }^{\text {91 }}$ Although Glenn's orbit was a tremendous event for the nonCommunist world, the United States was again in second place. German S. Titov, launched into orbit aboard Vostok II, was in space for more than a full day. Even so, Glenn's earth orbit was "big news in Moscow" and prompted praise from Nikita Khrushchev. It was suggested that the time maybe ripe for American-Russian cooperation in space. ${ }^{92}$

Glenn's flight proved the Atlas ICBM could be used for a peaceful purpose. The Cocoa Tribune described to readers that the Atlas was originally designed "as an intercontinental deterrent weapon in 1954 [and at the time] it was not thought as a booster for earth orbiting man." Its original purpose was to "launch a warhead into a high ballistic trajectory towards a target some 6200 miles away." But when the man-in-space program was announced, it was the Atlas that was chosen and modified as a space launch vehicle. ${ }^{93}$ The Cold War had truly extended to space, and, ironically, it was fought with the help of intercontinental ballistic missiles. Thus, while ICBMs were never launched

90 “Glenn Makes It!” The Cocoa Tribune, February 20, 1962, p. 1.

${ }^{91}$ Ibid.

92 "Khrushchev Sends Notes of Praise," The Cocoa Tribune, February 21, 1962, p. 3.

93 "AF Atlas Safe as Modern Man Could Make it, Team Dedicated," The Cocoa Tribune, February 20, 1962, special section. 
against a rival nation during the Cold War on earth, they were repeatedly launched into space to win the battle of the Space Age. ${ }^{94}$

When John Glenn landed, the nation and the non-Communist world were elated. The Cocoa Tribune had several personal advertisements of congratulations for their leading citizen, calling Glenn "Our Columbus." Within days the city was "feverishly preparing" for a visit from President John F. Kennedy to congratulate the astronaut. The mayor of Cocoa declared the day "Astronaut Day" and a parade was planned for the “entire rout from PAFB to Cape Canaveral." 95 Glenn's successful orbit-in addition to Titov's - underscored the race to land a man on the moon. But in August the Soviet Union again "dropped the bomb" at Cape Canaveral with the announcement that two Russians Cosmonauts were circling the earth simultaneously "within site of each other." The "double man space triumph" made it "painfully clear" that the United States was still behind Russia in the race for the moon. ${ }^{96}$ Although some hopes were shattered, it was

${ }^{94}$ In fact, the extension of the missile into the space race had many wondering if space was the new frontier of war. Although public concern was voiced in an article in The Cocoa Tribune, the newspaper was not forthcoming with an answer. Instead it printed a summation of the multi-million dollar projects taking place at missile test center. "Where Do We Stand in Space, Arms or Peace?” The Cocoa Tribune, June 21, 1963, p. 1.

95 "Excited beach Awaits Kennedy-Glenn Reunion," The Cocoa Tribune, February 22, 1962, p. 1.

96 "Cape Canaveral Officials React to Russian Man-in Space Feat," Titusville StarAdvocate, August 13, 1962. One official at NASA, who remained anonymous, commented "It will probably take a miracle for us to beat them to the moon. They've got a great head start-and their great booster power may keep them there. We can't hope to catch them for a number of years." Ibid. The Soviet cosmonauts were: Andrian G. Nikolayev launched in Vostok III on August $11^{\text {th }}$ and Pavel R. Popovich launched in Vostok $I V$ on August $12^{\text {th }}$. They were in space for 94 hours 22 minutes and 70 hours 57 minutes, respectively. http://history.nasa.gov/EP-107/ch9.htm 
evident that man could reach the stars. New dreams were created and others were reinforced. What was once considered science fiction was now truly becoming a reality.

The close of 1962 saw the transformation of Cape Canaveral into a Moonport. ${ }^{97}$ NASA was expanding and had plans to build a rocket transporter-crawler to move "a fully erected" Saturn-C rocket and its umbilical tower to its launch pad. ${ }^{98}$ An artist's conception of the vehicle appeared futuristic - not unlike an illustration imagined by H.G. Wells-but it was similar to what the crawler would eventually look like. ${ }^{99}$ Travel to space was changing the terrain on earth. In addition to missile testing, giant rockets, and machines large enough to transport both, the land itself was being reshaped to meet the growing demands of Spaceport U.S.A.

To accommodate the increasing challenges placed upon NASA to get man to the moon, the remaining 14,800 acres of northern Merritt Island were purchased-bringing total land ownership to about 90,000 acres. But NASA's expansion was a double-edged sword. The purchase would affect about 700 property owners in Brevard and Volusia counties, and "the towns of Shiloh and Allenhurst also will be taken over by NASA" leaving less than twelve thousand acres of the island in civilian hands. Many people

${ }^{97}$ This term was used by historians Charles D. Benson and William Barnaby Faherty to describe the transformation of Cape Canaveral into the portal to space. Charles D. Benson and William Barnaby Faherty Moonport: A History of Apollo Launch facilities and Operations (Washington D.C., 1978).

98 The umbilical tower "is the launch vehicle's life line to earth until the moment of liftoff." "Gemini-Titan II Air Force Launch Vehicle," Press Handbook, $2^{\text {nd }}$ ed., KSC Archives, Press Kit Collection, Box 2F.2, Folder 61.

99 "NASA Seeks 2 Crawlers to Move Moon Rocket," The Cocoa Tribune, December 19, 1962, p. 1. 
would be displaced by the administration's growth, but for others the growth was welcome news. The Florida East Coast Railway (FEC) project to extend track to AFMTC and the moon base was finally announced and embraced by contractors. Since 1950 , "every pound of construction material or equipment has had to be trucked in" because the FEC had "steadfastly refused" to extend its line to the base. But "the apparent magnitude of the Apollo project now warrants the expense."100 Within months, new construction was in full swing to modify the Moon Base for the lunar landing of Apollo.

The New Year began with NASA breaking ground on Merritt Island to build its Vertical Assembly Building-later renamed the Vehicle Assembly Building (VAB). It would be where the space vehicles would be put together before they were wheeled - or "crawled" - out to their launching platforms. The location of the chosen site was near the ocean and only a few feet above sea level, making it necessary to create a mound fortytwo feet high to support its weight. In fact, much of the land was dredged and filled to accommodate the weight of the massive buildings and machinery. The VAB would become the largest building in the state, with an "enclosed volume of 3.6 million cubic meters and an area of 32,000 square meters." ${ }^{101}$ In conjunction with the VAB, a launch Control Center was also being built to be “man's window for observing events projecting into the future." 102 In total the man-made Integrated Transfer and Launch area would

100 "FEC Lines to Moon Base, NASA Buys More Land," The Cocoa Tribune, December 19 , p. 1.

101 Charles D. Benson and William Barnaby Faherty Moonport: A History of Apollo Launch facilities and Operations, p. 231.

${ }^{102}$ Ibid., p. 225. 
include two launch pads with crawler passage roads, a crawler large enough to carry tenstory missile launch vehicles, the $\mathrm{VAB}$, the solid motor assembly and launch control. ${ }^{103}$ These new technological developments would lead to tightened security and restrict road access by residents. ${ }^{104}$

Simultaneously, the Air Force was transforming the land along the Banana River for the location of its Titan III launching complex (this would be later named Project Gemini). Made from a modified Titan II-the most formidable ICBM in the American missile arsenal to date, capable of carrying a ten-megaton nuclear warhead - the Titan III was the first launcher made without a "specified military purpose." It was "the most powerful and prime space booster for its time period." ${ }^{105}$ The progress of Cape Canaveral

103 “ 'Ground' Broken for Big Complex in Banana River," The Cocoa Tribune, February 18, 1963, p. 1.

104 "NASA-Area Roads, Bridge to be Closed to Public," The Cocoa Tribune, April 1, 1963 , p. 1. The impact of the space boom on the local community was noticed by Cape Canaveral planners, and members of the Canaveral Council of Technical Societies began answering resident questions several months before production began. In a Conference held by the Council in Daytona, various speakers lectured about technology, industry, science, and education. "Space Center Problems Will be Subject of Council Conference," Titusville Star-Advocate, October 24, 1962, p. 1C.

105 "Titan III to Fly in 18 Months: Strap-on Solid Boosters Key to Immense Thrust," The Cocoa Tribune, February 18, 1963, p. 1; Robert G. Whalen, "Visit to the Three Cape Kennedys," New York Times Magazine, December 13, 1964, KSC Archives, Brevard County Economic Impact, Box 38A.4, Folder 2. The Titan II was truly an evolution in missile making. The Cocoa Tribune referred to the missile as a "monster" because of its enormous size (103 feet) and weight (150 tons). The "key" to the missile's greatness was its ability to say fueled underground in silos and fired within two minutes time. The Titan II was at the time both a serious weapons and the key to space launch. "Titan II Success Ups U.S. in Arms and Space," The Cocoa Tribune, March 19, 1962, p. 1. 
created a new landscape, greatly impacting neighboring communities in ways that were not necessarily foreseen.

Growth of Cape Canaveral also meant growth of neighboring cities. The same day the groundbreaking of the Integrated Transfer and Launch complex was announced in The Cocoa Tribune, a related subject made top headline. The need for the construction of another 36,100 homes to accommodate the influx of new workers became a primary concern to residents. Area businessmen were told at a meeting entitled "Cocoa at the Crossroads" that NASA was going to be responsible for additional changes in the county. ${ }^{106}$ The previous year, "154 ballistic missiles and 343 weather rockets" were launched from the Cape, but that "was only a sample" of what was to come with the "two giant new programs" that the site would be handling this decade: the Gemini project to place two-man teams into orbit around the earth and the Apollo project to land men on the moon. ${ }^{107}$ Indeed, the rush of employees and their families to the eastern central part of Florida caused a housing shortage that left many questioning what to do.

The growing importance of each launch increasingly drew outside interest to the area, which highlighted the problem of lodging even before the influx of workers began. Cocoa Beach was a major destination for both the media and bidders anxious to be associated with the growing military-industrial-complex of the space coast. Some hotels had been expanded to accommodate the influx of visitors but there regularly continued to

\footnotetext{
106 “Another 36,100 Houses Needed in Next 7 Years," The Cocoa Tribune, February 18, 1963, p. 1.

107 "Big Test Future for Cape, AFMTC Scientist Assures," The Cocoa Tribune, March 21, 1963, p. 1.
} 
be a shortage of rooms. ${ }^{108}$ Changing launch dates helped keep the 1,200 motel rooms constantly full with newsmen alone. Limited capacity was especially noticeable when the new multi-million dollar complexes for the Gemini and Apollo programs brought sixteen prime contractor bids-each with their own team of men. Cocoa Beach motel men, it was claimed, had the NASA "tiger by the tail," but they also encountered problems of "how to schedule, reschedule, and reschedule again the limited rooms for the overflow of reservations they now possess."

Bidders were eager for a piece of the technological pie, but they were also drawn to the area as a result of its growth. Construction of apartment housing was a booming business, and in many cases it was a joint effort between contractors and the federal government-all in preparation for placing man on the moon. In April it was announced that the Federal Housing Association was going to finance its largest project in Cape Canaveral, "the most well-known landmark in the world." The 160-unit apartment complex was to be built over seven acres of prime land. ${ }^{110}$ By the middle of the month, almost all of the building permits issued in central Brevard County were for new homes. ${ }^{111}$ The scarcity of housing in the Cocoa area was well known and was mentioned

108 "Building Permits for Cocoa Beach Over \$5 Million," The Cocoa Tribune, June 29, 1962, p. 1.

109 "NASA Timetables Upset Motelmen Who Love It," The Cocoa Tribune, April 25, 1963, p. 1.

110 "Whitecliff Apts. For Canaveral," The Cocoa Tribune, April 1, 1963, p. 1.

111 "26 New Residences Head Permit List in Central Brevard," The Cocoa Tribune, April 25,1963 , p. 1. 
in the PAFB "Missileland Community" booklet distributed to military and civilians assigned to the base. "With the increase in population, housing became scarce, but the construction of many new housing sub-divisions has brought the situation under control." Even so, readers are alerted that "three and four bedroom rentals are not too plentiful," however, one and two bedroom units can be found more easily. ${ }^{12}$ The growing importance of space exploration and the race to the moon had a profound effect on surrounding communities and was especially evident in Cocoa. The city tripled in size making it one of the top ten cities in growth. ${ }^{113}$ This population increase was a microcosm of the growth of the Space Coast.

American perceptions of their landscape were changing to include outer space, but city borders within the country were physically changing as a direct result of the Space Age. Between 1950 and 1960 Brevard County was the fastest growing county in the United States with a population increase of almost four hundred percent. In comparison, the population growth during the same time period for the entire country was eighteen percent, and for the state of Florida it was seventy-nine percent. ${ }^{114}$ Put another

${ }^{112}$ Missileland Communities Present: 1963 Guide to Patrick Air Force Base Florida, KSC Archives, Missiles, Box 30A.4, Folder 6.

${ }^{113}$ In 1950 the southern mainland of Cocoa-Rockledge had a population of about 7, 365 people, Cocoa Beach had less than 250 people and Titusville had slightly over 5,000 residents. By 1960, the populations had risen to $23,392,10,490$, and 17,521, respectively. "The effects of Atlantic Missile Range Activity on Land, Highways and Utility Systems in the Vicinity of Cape Kennedy, Florida," KSC Archives, Brevard County Economic Impact, Box 38A.5, no Folder.

${ }^{114}$ Brevard had a population growth of 371.1 percent. The next highest growth increase was Orange County, at 129.2 percent. "Selected Facts and Figures on the Cape Canaveral Impact Area," $2^{\text {nd }}$ ed., revised, April 1963, KSC Archives, Brevard County Economic 
way, Brevard "compressed into a fifteen-year period what trends indicated would have been a half-century of "normal' growth." ${ }^{, 15}$ Nearly 88,000 people moved to Brevard during the 1950 s and almost as many moved to the county within the first four years of the 1960s. The "monumental distinction" placed on the Space Center "changed the course of Brevard County's history and has taken from it forever the destiny of being just another coastal Florida city.",116

NASA's expansion in the beginning of the decade caused Florida's governor, the Commander of the AFMTC, and the head of NASA's Launch Operations Center to meet to discuss the impact of the Space and Manned Lunar Landing Programs planned for Cape Canaveral on the surrounding area. This resulted in the formation of the Joint Impact Coordination Committee. Their purpose was to "identify, discuss, coordinate and recommend solutions or a course of action in connection with the problems" caused by the Cape Canaveral programs. There were six counties identified as being the most effected, but examination of the study indicates that these programs had the most impact

Impact, Box 38A.4, Folder 1. Because of high demand, the first printing of the report was exhausted, and prompted a revised edition for 1963.

115 If Brevard continued to grow at the same pace as it did before the reactivation of PAFB and the launching and testing facilities of the AFMTC and NASA, it would not have reached its 1965 level of population until "mid-way into the first decade of the next century." "The Effect of the Atlantic Missile Range on Land, Highways, and Utility Systems in the vicinity of Cape Canaveral, Florida," KSC Archives, Brevard County Economic Impact, Box 38A.5, no Folder.

116 "Selected Facts and Figures on the Cape Canaveral Impact Area," $2^{\text {nd }}$ ed., revised, April 1963, KSC Archives, Brevard County Economic Impact, Box 38A.4, Folder 1. 
on Brevard County. ${ }^{117}$ The Joint Impact Coordination Committee published a compilation of "facts and figures, pertaining to the impact area in order to answer many of the questions that have arisen." In addition to a population increase and housing concerns, the report showed a changing population demographic resulting in concerns about education and the continued growth of the scientific community.

A report by the Joint Impact Coordination Committee showed concerns about education in the sciences and opportunities for continued education for the rising population. This was especially evident in Brevard. Compared to the five other counties in the impact report, Brevard's statistics showed that younger families with higher levels of education were moving to the area—resulting in a changing demographic. ${ }^{118}$ By 1960 the county had the largest percentage of its workforce in white-collar jobs, which resulted in the highest median family income. ${ }^{119}$ As a result of this changing demographic, the importance of education came to the forefront of resident concern. "With the advent of scientific and technical employment characteristics at the Atlantic Missile Test Range, higher education has received considerable attention." Perhaps no other place in the

117 The six counties were: Brevard, Indian River, Orange, Osceola, Seminole, and Volusia. Ibid.

118 These families had more children under five than others in the impact area. Consequently, the large number of children under the age of five added to the immediate need for more schools and this need would have a domino effect as the years progressed. Since many of these children were from while collar families, it could also be assumed that they would attend college or technical school. Ibid.

${ }^{119}$ Brevard had 14.2 percent of its population under five years old, compared with Indian River (11), Orange (12), Osceola (9.2), Seminole (13.1), and Volusia (8.6). Brevard also had the highest number of residents who completed high school or had more years of schooling, at 54.3 percent. The other county percentages were $43,48.8,32.6,43.6$, and 46.9 , respectively. Ibid. 
country encapsulated future technological endeavors better than the scientific and engineering community at Cape Canaveral. The space age heralded in an interest in science that has no comparison in the twentieth century. Although existing facilities made changes to offer more courses and enlarge capacity, these statistics indicate the need for more schools, continued education, and higher education for future students. ${ }^{120}$

Brevard County took advantage of its resident scientists and its proximity to the missile test range by opening Brevard Junior College - the "only publicly supported institute of higher learning in the Cape Canaveral missile area"-and staffing the college with fifty-seven "prominent missile and space scientists" as part-time instructors. The need for the college was greater than expected. Before its completion, a survey indicated that two hundred fifty students would enroll, but when the doors opened in fall 1960, 768 people enrolled. By 1963 over 2,000 students attended, making the junior college "one of the largest in the state." Within one decade, enrollment was expected to climb to 9,000 . What is also telling is the increased percentage of graduates continuing their education after high school: before 1961 less than thirty percent of high school students continued to higher learning, after the college opened in 1961, the number increased to over seventy-two percent. ${ }^{121}$ The physical characteristics of the land were continually transformed as more emphasis was placed on conquering the New Frontier. Old roads were widened and new roads and causeways were built to accommodate the increased traffic of new residents and incoming tourists to the "Platinum Coast."

${ }^{120}$ Ibid.

${ }^{121}$ Ibid. 
One result of NASA's commitment to Brevard County was a study conducted by the East Central Florida Regional Planning Council on the effects of the missile range on land, highways, and utilities. The council's intent was to "fulfill the community development policy gaps which plagued the Cape area" since its reactivation. The council concluded that the federal government had a "social responsibility" to help communities where it introduced "massive programs." Interestingly, the council recommended NASA use a version of "war games" used by think tanks and military planners, which they called "development games" to help identify impact problems "before program changes became realities." These games would allow both the community and federal agencies to examine all the possible problems that would result from such large-scale programs. ${ }^{122}$ Games_-like missiles—were originally developed as a means for fighting war. Both still had their original purpose, but the space age had transferred their use to a more peaceful battle. This non-violent war, however, was briefly interrupted with the Cuban Missile Crisis.

When President Kennedy announced to the United States that the Soviet Union had placed missiles ninety-miles off the coast of Florida, people living in the Cape Canaveral area were not as frightened as those in the rest of the country. Cape residents had absorbed missiles into their everyday lives, and their proximity to the Soviet missiles did not instill fear. Only one year before, it was revealed that the Air Force had sent a series of missiles into orbit to protect the United States from "sneak rocket attack." The Midas

\footnotetext{
122 "The Effect of the Atlantic Missile Range on Land, Highways, and Utility Systems in the vicinity of Cape Canaveral, Florida," KSC Archives, Brevard County Economic Impact, Box 38A.5, no Folder.
} 
"watchdog satellite" (short for missile defense alarm system) was designed to "trace a path over the North and South Poles while carrying an infrared rocket-hunting payload over every spot of the earth at one time or another-including Russia."123 In fact, Americans were warned repeatedly that the Soviet Union might launch a "sneak missile attack" on the United States. When Russia tested a fifty-megaton nuclear bomb in the fall of 1961, it was hypothesized that it had the capability to "completely blockout (sic) short wave radio communications and jam early missile warning radar." In essence, it would “create a smoke screen" for an all out attack on the United States. ${ }^{124}$ There is no mistake that the Cuban Missile Crisis placed the Cape on high alert. The incident, however, failed to make more than a few headlines. ${ }^{125}$ Cape Canaveral was not considered a target because it was only a test center. ${ }^{126}$

The Air Force continued to develop its missile arsenal and was working closely with NASA to modify the Titan II for the manned space flight missions of Project Gemini. The successful conclusion of the Titan II as an operational weapon marked the "start of the realization of its many potentialities as a launch vehicle-for both the

\footnotetext{
123 "Midas guards Against Sneak Rocket Attack," The Cocoa Tribune, July 13, 1961, p.
} 1.

124 "50 Megaton Bomb Seen as Smoke Screen for Sneak Missile Attack," The Cocoa Tribune, October 23, 1961, p. 1.

125“Nuclear Missiles on Cuban Pads Aimed at United States," Titusville Star-Tribune, October 23, 1962, p. 3; "Arms Defense Buildup in Florida Covers Strategic Points," The Cocoa Tribune, October 23, 1962, p. 1; "Military Buildup Noticeable Through Activities Here," The Cocoa Tribune, October 24, 1962, p. 3.

${ }^{126}$ Elbert E. (Sonny) Witt, Deputy Commander at Cape Canaveral Air Force Station, Interview by Jessica Barrella, Cape Canaveral, Florida, April 25, 2006. 
civilian space program in Project Gemini and the Air Force space program as the core vehicle for the Titan III standard space launch vehicle."127

The Titan II was announced as the Gemini launch vehicle even before it had completed development for two main reasons: it would be the only rocket available for the Gemini flight schedule, and its storable liquid fuel allowed for "easier operational handling" and required no "ignition system." Gemini was the stepping-stone to "the lunar goals" of Apollo. It differed from Mercury in that it launched two men into space within one capsule and provided "extravehicular activities" to prepare for a lunar expedition. ${ }^{128}$ The Gemini-Titan III flights were designed to be the inaugural ten steps (of a twenty five step program) to place man on the moon. ${ }^{129}$ By the middle of the decade, the first seven steps were taken: the first two flights were unmanned but the next five each sent two men into space. Gemini XII was the longest American space flight, lasting 330 hours and thirty-five minutes. Cape Canaveral was living up to its reputation as Spaceport U.S.A., the gateway to the moon.

In fifteen short years, both the missile and the Cape vicinity transformed. Missiles originally designed to deter and destroy the enemy were propelled to a peaceful purpose in space age. The ICBM was never used against the Soviet Union as a weapon; rather it

127 “Gemini-Titan II Air Force Launch Vehicle," Press Handbook, $2^{\text {nd }}$ ed., KSC Archives, Press Kit Collection, Box 2F.2, Folder 61.

${ }^{128}$ Ibid. Mercury's pilot was only in an observer capacity. "U.S. Air Force Information Kit," KSC Archives, Visitor's Information Center Collection, Box 17B.1, Folder Cape Canaveral/ AF.

129 "25 Giant Steps to the Moon," reprinted from Aerospace (Summer 1964), KSC Archives, Visitor's Information Collection, Box 17B.1, no Folder. 
was launched into space win the battle of the Space Age. ${ }^{130}$ As a result of the race to space, Americans embraced science and missile technology and felt personally vested in the struggle to beat the Soviet Union. This was especially true for residents near the Spaceport: they felt personally involved in missile development and welcomed the new technology into their communities. The missile changed the landscape of Cape Canaveral and propelled Titusville and Cocoa to the focal point of the Free World's space endeavor.

${ }^{130}$ In fact, the extension of the missile into the space race had many wondering if space was the new frontier of war. Although public concern was voiced in an article in The Cocoa Tribune, the newspaper was not forthcoming with an answer. Instead it printed a summation of the multi-million dollar projects taking place at missile test center. "Where Do We Stand in Space, Arms or Peace?” The Cocoa Tribune, June 21, 1963, p. 1. 


\section{Chapter 6}

\section{The Missile Nest:}

\section{Hidden Missiles in the Great Plains}

Twentieth century man has brought [war] to its highly refined present state of unspeakable horror and impersonality. The massacres and atrocities of enraged soldiers in past history are horrifying, yet they are within the human dimension. But the impersonal obliteration of a million people in an instant by a cool 'soldier' hundreds or thousands of miles away transcends the human equation. ${ }^{1}$

By 1957 it was clear that intercontinental ballistic missiles were to be America's first line of defense against the Soviet Union. One year later, sites within the Great Plains were chosen to house the new thermonuclear weapon, and by 1959 digging began. The Great Plains were chosen for two main reasons: it was the interior of the country and many felt it was safely away from vulnerable American borders, and it was home to vast amounts of primarily flat land which was sparsely populated. When the ICBMs arrived in local communities they were celebrated-for economic and security reasons. Most communities within the Great Plains accepted missiles in their backyards, but each area viewed the "birds" differently. Missile bases would add to the local economy, if only temporarily, but there were consequences. Thermonuclear ICBMs made once quiet and virtually unknown interior cities of the United States prime enemy targets, exposing them to new dangers and creating a real need for local civil defense. Whereas civil defense called for dispersing people from cities vulnerable to Soviet attack to the countryside,

\footnotetext{
${ }^{1}$ Thomas L. Martin, Jr., and Donald C. Latham, Strategy for Survival, (Tucson, 1963), p. 33.
} 
now the countryside itself was the target, as the Soviet Union aimed their missiles on America's ICBM arsenal.

The Great Plains was a vital location for a number of key Cold War defense installations even before it became home to the ICBM. F.E. Warren Air Force Base was located in Cheyenne, Wyoming and NORAD only 170 mile directly south of the city in Cheyenne Mountain, Colorado Springs, Colorado. NORAD was built within a mountain and was the "hub" of national defense against attacking airplanes and missiles. ${ }^{2}$ The Sioux Ordinance Depot in Sidney, Nebraska, was less then one hundred miles east of Cheyenne. SAC and Offutt AFB, in Omaha, and Ellsworth AFB near Rapid City South Dakota, were only several hundred miles away.

Cheyenne was the first city to have the exclusive operational mission of a ballistic missile base. ${ }^{3}$ Four Atlas D installations were planned to ring the city: site A was twenty miles northwest of the city, site B was about twenty miles northeast, site $\mathrm{C}$ was sixteen miles southeast, and site D was thirteen miles southwest of Cheyenne. While site A (also known as Warren I) was being built, the other three sites (Warren II) were under contract. Site A had two complexes with three missiles each and one launch control center (LCC),

${ }^{2}$ NORAD was made infamous in Fail-Safe and Dr. Strangelove, It is portrayed as a room with a large monitor of the world to track incoming attacking missiles and aircraft. NORAD, it was believed, was hardened to withstand a direct hit and still remain operational during war.

${ }^{3}$ Vandenberg AFB in California was the first location of the Atlas missile, but the location was used primarily as a training base. Incidentally, the $706^{\text {th }}$ Strategic Missile Wing - the "free world's first operational missile wing" - celebrated its first anniversary before the missiles were activated. " $706^{\text {th }}$ Missile Wing Marks First Birthday," Wyoming State Tribune, February 22, 1959, p. 2.

The Atlas A, B, and C were test missiles and never deployed. 
and sites B, C, and D had one complex with one LCC and three missiles each. This would be the typical Atlas D configuration: $3 \times 3$ : three missiles per LCC and three complexes per squadron.

The Atlas was the first intercontinental ballistic missile: it did not operate by simply pushing a button and its development was a learning process for successor ICBMs. The Atlas was relatively handmade and house on a complex site, which required much manpower and machinery to operate. The first deployed in the series, the Atlas D missiles were clustered together because they were radio-controlled and needed to be close to their transmitters and each LCC needed a crew of twelve men. Unlike later missiles, the Atlas D was also exposed to blast. It was placed horizontally in a "soft" aboveground coffin-shaped bunker that was only able to withstand an overpressure of five pounds per square inch (psi) - the amount of force that is exerted over every square inch of a given surface. ${ }^{4}$ Thus the first deployed ICBM was vulnerable to enemy attack in three ways: the radio-controlled guidance system was susceptible to jamming; the missile could not be adequately dispersed for protection, and it was not protected or "hardened." These issues would subsequently be changed in the Atlas E and F. As we will see, over

${ }^{4} 5$ psi corresponds to 720 pounds per square foot. Thomas L. Martin, Jr., and Donald C. Latham, Strategy for Survival, p. 66. "The normal atmospheric pressure above sea level is 15 psi. Overpressure is an additional, transient pressure created by the shock or blast following a powerful explosion. Buildings collapse at 6psi overpressure." John C. Lonnquest and David F. Winkler. To Defend and Deter: The Legacy of the United States Cold War Missile Program, vol. II (Champaign, Illinois, 1996), fn. p. 68.

The missiles at Vandenberg were not sheltered at all. They stood erect and were held by a gantry which was rolled back before launch. David K. Stumpf, Titan II: A History of a Cold War Missile Program (Fayetteville, Arizona, 2000), p. 11. 
time the ICBM will become simpler to operate and house, requiring minimal human interaction as they became increasingly automated.

Although the Atlas D was not as sophisticated as later versions of the same missile, it, nonetheless was a very powerful weapon. The D had a "stage-and-a-half" propulsion system, measuring slightly over eighty-two feet in height and ten feet in diameter. It traveled at 16,000 miles per hour with a range of over 6,300 miles-able to hit a city in the Soviet Union. When ready to launch, the Atlas D was lifted to a vertical position and fueled with liquid oxygen (LOX) and rocket propellant kerosene. This first generation liquid fueled missile took time to launch. In addition, fueling was "extremely delicate and hazardous" because LOX was combustible when combined with kerosene. "A chance spark or "combustion instability' in the engine could trigger an explosion." In fact, this issue would plague Atlas engineers throughout its development. ${ }^{6}$ The missile needed to be fueled right before launch — it could not be stored already fueled like later missiles. Fueling alone took up to fifteen minutes and given the shortened reaction time of incoming weapons in the Missile Age, that was a long time. The Atlas D carried a 1.44 megaton warhead and had an impressive targetability of two miles. ${ }^{7}$ Circular error

5 Jacob Neufeld, Ballistic Missiles in the United States Air Force, 1945-1960 (Washington, D.C., 1990), p. 203.

${ }^{6}$ John G. Lunn, LTC (Ret.) former civilian engineer with Convair/ General Dynamics in San Diego, California, working on the Atlas D from 1960-1965. Interview by Jessica Barrella, via phone, July 27, 2006.

7 The nuclear strength of the Atlas caused concern among residents that they might accidentally explode. General Bernard Schriever assured citizens that the missiles could not accidentally explode while in storage. "Cheyenne Atlas Project Said 'On Schedule,", Wyoming State Tribune, February 24, 1959, p. 2. By mid-summer, the Atlas appeared to 
probable (CEP) denotes the accuracy of a weapon — or its ability to hit a bull's eye. The CEP is also the area that will be inflicted with the most damage. The lower the CEP, the better the weapon's accuracy. The Atlas D was impressive for its time, and it was the most powerful weapon in the United States arsenal.

Those living in and around Cheyenne were receptive to the deployment of the Atlas to their area-although there were two condemnation suits filed against landowners, one at site $\mathrm{B}$ and one at site $\mathrm{C} .^{8} \mathrm{~A}$ local survey printed in the Wheatland Times showed that 84.6 percent of the 411 "individuals living in all parts of the city" that were polled favored the missile construction. ${ }^{9}$ The Atlas brought jobs and business to the area. Construction of the sites was contracted out to the lowest bidders, but sub-contracts were let to local businesses, therefore helping the economy. In all, most of the work force on each site consisted of local workers. ${ }^{10}$ As the deployment of the Atlas expanded,

have several setbacks after "five consecutive misfirings" during test flights. But Lieutenant General Bernard Schriever testified that there was no need for alarm. "Confidence Voiced in Atlas ICBM: Schriever says Misfirings No Cause for Alarm," Wyoming State Tribune, July 28, 1959, p. 1.

${ }^{8}$ Site B was filed for 767.94 acres of land and Site C was for 93.62 acres of land. The landowners were given $\$ 22,320$ and $\$ 3,260$ respectively by the government. "Atlas Sites Land Action Filed in Court," Wyoming State Tribune, March 5, 1959, p. 1.

${ }^{9}$ The poll breaks down as follows; $69.8 \%$ indicated that they "liked the idea of a missile base at first and that they still did, while $14.8 \%$ stated that they did not like the idea at first but now accepted it." "New Missile base Favored by $84.6 \%$ in Recent Survey," The Wheatland Times, August 4, 1958, p. 4.

10 Residents were very interested in the contractors that won successful missile construction bids. When Blount Construction Company won the prime contract for missile sites B, C, and D, the Wyoming State Tribune and Wyoming Eagle printed a full- 
Warren AFB grew in strategic missile importance. Like Cape Canaveral, missile construction caused the area to grow, but the growth was temporary-as was the Atlas missile itself. All four sites circling Cheyenne were only active for three years. ${ }^{11}$ The prestige that the ICBM brought to the community, however, was long lasting. ${ }^{12}$

The Atlas made evident that missile technology was rapidly changing. Missile sites were being reconfigured mid-construction to meet new design specifications of changing technology. ${ }^{13}$ This was a result of the concurrency concept initiated by Bernard Schriever. To excel the pace of missile development and deployment, flight-testing, design, site construction and installation were undertaken in narrow and overlapping time frames so that everything could be ready at roughly the same time. ${ }^{14}$ The rapid pace of development was apparent to locals when a Wyoming State Tribune editorial asked readers: "Will the Atlas bases currently under construction be able to handle later long-

page article about the history of the company and its past missile endeavors. "Blount, Main Atlas Missile Site Contractor, Top Construction Firm," Wyoming State Tribune and Wyoming Eagle, July 21-24, 1959, p. 2B.

${ }^{11}$ They were activated by the end of 1961 and deactivated by the end of 1964 .

${ }^{12}$ Local Cheyenne newspapers often printed informative articles and pictures about Atlas missile technology. "Space Technology Laboratories responsible for Atlas Systems," Wyoming State Tribune, July 21, 1959, p. 26.

1335 modifications were made to the guidance facility and 117 to the launchers before the George A. Fuller Company completed its contract.

http://209.85.165.104/search?q=cache:uf7KVO46U8wJ:www.globalsecurity.org/wmd/fa cility $/$ warren. $h t m+$ atlas + missile + cheyenne, + wyoming $\& h l=e n \& g l=u s \& c t=c \ln k \& c d=4$

${ }^{14}$ There were two drawbacks to the concurrency method: duplication and cost. Jacob Neufeld, Ballistic Missiles, p. 201. 
range missiles as they are developed or will the bases become obsolete?"15 Air Force Secretary Dudley Sharpe denied rumors that the Atlas sites would be "obsolete in three years and abandoned leaving the Cheyenne economy in difficulty." The sites would be modernized to match new technology, he promised. ${ }^{16}$ Constant design modifications would eventually put the Atlas slightly behind schedule, but many locals would attribute the delay to striking workers. ${ }^{17}$

Site A encountered the first of many workers' strikes in mid-April 1959. The strike of Operating Plasterers and Cement Masons idled 400 missile base workers. They demanded a travel allowance from George E. Fuller Construction Company, the site subcontractor. The strike was short-lived and workers agreed to return to work with their demands not met. ${ }^{18}$ Another strike by the International Plumbers and Steamfitters idled over 500 workers in August when they contested the use of non-union workers. The strike stopped work most of the month and made front-page news. Electrical workers picketed the site to contest wages, arguing that the Davis-Bacon Act was violated. ${ }^{19}$ The

\footnotetext{
15 “Atlas Bases and Obsolescence," Editorial, Wyoming State Tribune, April 1, 1959, p. 10.

16 “"’Site A Operational Sept. 1, Sharp Says,” Wyoming State Tribune, July 21, 1960, p. 1.

17 "Back of the Delay in U.S. Missile Bases," U.S. news and World Report, May 1, 1961, p. 61 .
}

18 "Cement Workers End strike at Warren Base Missile Site: Allowance for Travel Rejected," Wyoming State Tribune, April 19, 1959, p. 1.

19 "Meeting Set in Missile Site Strike: Electrical Workers Continue Picketing," Wyoming State Tribune, March 15, 1960, p. 1; "Workers End Strike at Atlas Missile Site: Understanding is Reached with Union," Wyoming State Tribune, March 16, 1960, p. 2; "Strike Called at Missile Sites: 1,000 Workers walk off Jobs," Wyoming State Tribune, 
Act protects local workers on federal construction jobs by providing them with "existing wages for certain work" in that specific area. ${ }^{20}$ This concern would eventually trickle to sites $\mathrm{B}, \mathrm{C}$, and $\mathrm{D}$ and become a recurring issue. ${ }^{21}$ There were only four labor workstoppages for Site A, but strikes persisted at the other sites because as one labor representative noted, "our position is that this is the first of the bases and [labor has] to establish policy with respect to contractor jobs on this base so that this type of thing can be prevented on other bases." 22 Union workers were attempting to set a national example at the first of what was expected to be a proliferation of bases. Contrary to what many locals thought, strikers did not feel that they were being unpatriotic by halting missile

March 24, 1960, p. 1; "Missile Base Strike Discussed: Pickets remain at Three Sites," Wyoming State Tribune, March 25, 1960, p. 1.

20 "Union Issue Idles Atlas Force: 500 Stay Away from Jobs at Project Site A," Wyoming State Tribune, August 6, 1959, p. 1; "Picket Halts Missile Site Work: Plumbers Renew Stoppage," Wyoming State Tribune, August 17, 1959, p. 1;"Atlas Missile Site Remains Closed by Union Picket Line," Wyoming State Tribune, August 18, 1959, p. 1; "Missile Site Workers Are Returning to Their Jobs," Wyoming State Tribune, August 20, 1959, p. 1; "NRLB Picketing Injunction: Site A Walkout Is Off Pending Court Hearing," Wyoming State Tribune, August 23, 1959, p. 1; "Union Faces Hearing in Atlas Base Work Issue," Wyoming State Tribune, August 24, 1959, p. 1; "Peace reigns at Site A," Wyoming State Tribune, August 28, 1959, p. 1.

21 Stoppage reached all four launch construction sites by the end of March 1960. "Workers Return to Jobs at Missile Site," Wyoming State Tribune, May 27, 1960, p. 1; "Second Union on Strike at Four Missile Sites: Dispute over Wage Causes New Walkout," Wyoming State Tribune, May 12, 1960, p. 1; "Strike Set at All Missile Bases: Nationwide Walkout Set Late Sunday," Wyoming State Tribune, June 5, 1960, p. 1;"Strike Halts Atlas Site Work: Walkout Closes Four Major Bases," Wyoming State Tribune, June 6, 1960, p. 1

22 "Labor-Management Pattern Sought in Missile Field Work," Wyoming State Tribune, June 14, 1960, p. 1. Sites B, C, and D had a total of 11 work related stoppages. http://209.85.165.104/search?q=cache:uf7KVO46U8wJ:www.globalsecurity.org/wmd/fa cility/warren.htm + atlas + missile + cheyenne, + wyoming $\& h \mathrm{l}=\mathrm{en} \& \mathrm{gl}=\mathrm{us} \& \mathrm{ct}=\mathrm{clnk} \& \mathrm{~cd}=4$ 
base construction. They believed that they should be treated fairly by the government. It was a fair trade off: these same people made concessions to put thermonuclear weapons in their communities.

Labor strikes did push back site activation, but concurrency had more to do with site construction setbacks than worker strikes. Concurrency made missile site development slow because many of the site specifications had to be redrawn or reconstructed - making redundancy a prevailing characteristic at early missile sites. What many residents - and Americans as a whole - saw, however, were delays in missile site construction. Periodicals and newspapers highlighted worker strikes and this led many to believe that that United States would never catch up with the Soviet Union and that the missile gap would not be closed any time soon. What the press did not report was much of the site construction delays were caused by the rate of technological innovation: missile site construction could not keep pace with missile development.

Residents, however, were not sympathetic to the prevailing strikes and constant work stoppages, thinking them unpatriotic. ${ }^{23}$ One rancher commented: "I think it's wrong. Here we are trying to get ready to protect ourselves with people striking. It doesn't show good Americanism." ${ }^{24}$ Like other residents, this rancher interpreted strikes on national defense projects as jeopardizing everyone: strikers were being selfish, looking to fulfill their own personal needs before that of the nation. Just the opposite was true.

23 “Our Missile Program Lag,” Editorial, Wyoming State Tribune, June 14, 1960, p. 6. 24 "Reaction to Strike is Mixed," Wyoming State Tribune, May 12, 1960, p. 1. Although the headline says there were mixed reviews, the opinions cited were primarily negative. 
Strikers were trying to assure workers on other national defense installations would be treated fairly and the government would be held to the same accountability as large companies. Residents in and near Cheyenne, however, had an intimate relationship with Warren $\mathrm{AFB}$, and viewed a rift as un-neighborly, if not unpatriotic.

The city of Cheyenne had a long and interdependent relationship with nearby Warren Air Force Base, of which they were proud. Troops were first stationed at Fort D.A. Russell in 1867 to protect workers building the Union Pacific Railroad. That same year Cheyenne was founded. Less than twenty years later, a telephone line connected the city to the Fort, and Cheyenne's first Frontier Days celebration in 1897 included the fort's garrison. ${ }^{25}$ Cheyenne was still commemorating Frontier Days when the Atlas missile was being placed around the city to protect the nation from enemy attack. There was the tight bond between the city and the Air Force Base. Both understood that their foundation depended on the other. This bond was reinforced during the Missile Age as the base and Cheyenne's strategic importance grew. Like other bases around the country, Warren was open to the public for Armed Forces Day, and in 1960, the Atlas was its main attraction. ${ }^{26}$ Residents flocked to honor the missile.

Like advertisements in national news magazines, prime missile contractors often commemorated the city and the base in full-page advertisements in local newspapers. Convair, the principal contractor for the Atlas, thanked the Atlas team and described the

25 "WAFB Vital Link in SAC Defense Chain: History of Base goes Back to 1867," Wyoming State Tribune, May 21, 1960, p. 18.

26 “Atlas Display Highlights 'Forces Day," Wyoming State Tribune, May 22, 1960, p. 1. 
breakdown of the headquarters Ballistic Missile Division. ${ }^{27}$ General Electric (a defense contractor) noted how the area used to be symbolized by the Sioux Indian Arrow but was replaced by the Atlas: Warren AFB had become the major deterrent to Soviet aggression, it was announced. ${ }^{28}$ One contractor associated itself with Frontier Days, but replaced the traditional American frontier with space. ${ }^{29}$ These advertisements tied the community and Warren AFB together and connected the contractor to both.

Like the contractors that were responsible for building missile defense installations, citizens in and around Cheyenne were just as proud that they were chosen to be a part of something so important. Cheyenne was at the heart of the nation and was on its way to resurrecting its prior fame of the transcontinental railroad days. Wyoming Senator Gale McGee (D) confirmed this belief when he told a local audience "Wyoming stands at the gateway of western development, which is imperative if the nation is to expand its economy." Missile installations would generate more power and prestige for western states in Congress. ${ }^{30}$ These states with traditionally low populations would garner more clout because of their strategic location and increased importance in protecting the

27 “The Atlas Team,” Advertisement, Wyoming State Tribune, July 26, 1960, p. 32.

28 "Warren AFB from the Arrow to the Atlas," Advertisement, Wyoming State Tribune and Wyoming Eagle, July 21-24, 1959, p. 6B.

29 "Pointing the Way to the New Frontier . . . Space," Advertisement, Wyoming State Tribune, July 21, 1959, p. 21.

30 "McGee tells Cheyenne . . Not to Put all Eggs in 'Missile Basket,"' Wyoming State Tribune, March 3, 1959, p. 1. 
nation. In 1959 the Wyoming State Tribune proudly named the state the "Free World's first line of defense." ${ }^{\prime 31}$

1960 marked the seventieth anniversary of both the city and the base. The Missile Age brought with it a replacement of the symbolic state symbol of a cowboy on a bucking horse with a cowboy on a roaring missile. The caption read: "Ride "em Cowboy." 32 Cheyenne Light, Fuel and Power Company named Cheyenne "the world's no. 1 Missile City." The advertisement described state residents as having "a loyalty and vigorous approach to life in its entirety that is not typical of other areas of the country." Speaking for the entire city, it continued, citizens were "deeply and sincerely proud that their community represents the free world's first line of defense." Residents were not frightened that the position of the Atlas made the area a "prime target for the enemy." Rather, they live their day-to-day lives with a "zeal and zest for living" that differentiates the community from all others. ${ }^{33}$ These advertisements epitomized local sentiment, and by doing so, heightened patriotic fervor.

Construction of the four Wyoming Atlas sites was going so well and missile development progressing so quickly that the Air Force authorized an expansion to

\footnotetext{
31 "Wyoming Products Edition," Wyoming State Tribune and Wyoming Eagle, July 21, 1959, p. 41.

32 "Wyoming Products Edition," Wyoming State Tribune and Wyoming Eagle, July 2629, 1960, p. 1C.

33 “Cheyenne, The World's No. 1 Missile City," Advertisement, Wyoming State Tribune and Wyoming Eagle, July 26-29, 1960, p. 5B.
} 
Warren AFB to include an additional squadron of nine missiles: the new Atlas E. ${ }^{34}$ These sites would extend from Wyoming into northeastern Colorado and the panhandle of Nebraska. Construction work began on December 7, 1959. Anticipating public concern that rapid Atlas development would make the missile obsolete and sites becoming abandoned, it was also announced that the government was going to lease the land rather than buy it for the new sites. ${ }^{35}$

The announcement that Kimball, Nebraska would be part of the Warren III complex was well received by city locals. ${ }^{36}$ Located in the panhandle of the state, the missile site was described as being "in the midst of wheat fields atop a wind swept hill.",37 Actually the location sounds more scenic than it is: the area around Kimball is barren land surrounded by primarily sunflower fields. Because of the remoteness of the area, one editorial argued that the only business that Western Nebraska could attract was defense work. It "behooves every Nebraskan to bombard his Senators and Congressmen with a never-ending barrage of mail" asking to consider Nebraska for more missile installations.

34 "AF Announces Additional Atlas Missile Base facilities," Wyoming State Tribune, March 15, 1959, p. 1; "AF Authorizes Atlas Base Expansion," Wyoming State Tribune, June 5, 1959, p. 1; "Cheyenne's Missile Defense Free World: Warren Complex to Have 13 Atlas Launching Sites," Wyoming State Tribune and Wyoming Eagle, July 21-24, 1959, p. 26B.

35 "Warren to get New Air Division: Command Unit to Be Formed During July," Wyoming State Tribune, June 7, 1959, p. 1.

36 "Kimball is Launching Site . . 42-Missile Defense is Planned for this Area," Sidney Telegraph, June 8, 1959, p. 1.

37 "Entire Launching Base Underground . . . Construction Begins on Western Nebraska's First Missile Site," Sidney Telegraph, February 5, 1960, p. 1. 
Indeed, Nebraska was known for its farm communities and oil wells, but not much else. But some residents did not want the state to be known for national defense. One editorial described the transformation of missiles in his backyard to "a matador who is holding a red flag." Regardless, it was the patriotic duty of all residents to "do their best" to make sure the installations were completed and ready for use. ${ }^{38}$ Without the help of residents, national defense would be in jeopardy. Soon all reports were quick to lump "the growing city of Kimball" with the missile fortresses of Wyoming and Colorado.

The new Atlas E was configured in a $1 \times 9$ arrangement: there were nine missiles, each with a separate LCC. The ICBM was placed horizontally in a coffin, but it was covered with soil on all sides except the top door and side-loading door, making it a semi-hardened site, capable of withstanding 25 psi. Each site had grown to include about fifteen to thirty acres of land. There were two buildings underground connected by a one hundred foot tunnel. The E used an all-inertial guidance system so it could be dispersed eighteen miles apart for blast protection. ${ }^{39}$ The Air Force began to carefully configure its missiles and squadrons to absorb an enemy blow, forcing the Soviets to target each missile individually. This had positive and negative effects. Missiles were becoming virtually indestructible as a force, but their dispersal meant more direct damage to surrounding communities in time of war. Eventually, three Atlas E squadrons would be

38 "Kimball as Missile Base," As Other Editors See It (Western Nebraska Observer), Sidney Telegraph, July 20, 1959, sec. 2, p. 4.

39 The Atlas E underground structure was designed to absorb a one-megaton blast up to 1.6 miles away with the walls and ceiling between 18 and 24 inches thick. Don Zwonitzer Interview by Jessica Barrella, Kimball, Nebraska, October 2, 2006. 
deployed throughout the United States, totaling twenty-seven missiles, and like the D, the Atlas E was short lived: the first became operational in 1961 and the last deactivated by the close of $1965 .^{40}$

The successor, the Atlas F became operational in 1962, and it was the most advanced of the series. It was stored vertically within a silo and was able to be fueled in its silo before it was raised to the surface for launch. It was dispersed in a $1 \times 12$ arrangement of six squadrons and was the first hardened missile able to withstand $100 \mathrm{psi}$ overpressure - but this would pale in comparison to the hardness of future missiles. The $\mathrm{F}$ was also the only Atlas system that was capable of launching more than one missile at a time from a given complex. ${ }^{41}$ This last version of the Atlas had the shortest life spanonly three years. Deployed in 1962, they were deactivated in 1965. In all, the nation housed 132 Atlas missiles, between 1961 and 1965. Eighteen resided in Wyoming, five in Colorado, and nineteen in Nebraska, with the majority of the others were scattered west of the Mississippi. ${ }^{42}$

Another missile was being developed simultaneously with the Atlas. Several

${ }^{40}$ The Atlas E was deployed in Washington, Wyoming, and Kansas, with one each in Vandenberg, Nebraska, and Idaho. John C. Lonnquest and David F. Winkler. To Defend and Deter: The Legacy of the United States Cold War Missile Program, vol. II, pp. 574576.

41 David Baker, The Rocket: The History and Development of Rocket \& Missile Technology (New York, 1978), p. 232.

42 Atlas missiles were located in Iowa, Kansas, New Mexico, Oklahoma, Texas, and Washington. Two were located in Vermont, and a squadron of 12 was in New York. John C. Lonnquest and David F. Winkler. To Defend and Deter: The Legacy of the United States Cold War Missile Program, vol. II, pp. 574-576. 
committees, including RAND, came to the conclusion that ballistic missile development - and specifically Convair (the primary Atlas contractor)-needed more competition and it was believed that a two-stage missile would increase its payload and range. The competing contractor was the Martin Company and its missile was the Titan. Martin began work in a new facility near Denver, an area believed to be safer than its competitor location in coastal Southern California—-"within range of Soviet bombers and Soviet Submarine-launch IRBMs."43 Titan project did not begin until 1957, but its progress was rapid. In February 1959, the Titan had its first successful launch at Cape Canaveral and was activated the next year. Meanwhile, there was growing concern among Americans about the strength of the national defense program.

Military planners assured the public that more advanced weapons-especially missiles-would secure peace. This was called missile deterrence. ${ }^{44}$ Residents of the Plains were eager to learn more about the new Soviet deterrent, and on March 13, 1959, the Martin Company unveiled its missile to locals with much fanfare. Like Cheyenne, Denver offered some spectacular historical associations to introduce the new Titan to residents. The city showcased the Titan with a "100-year-old log cabin used by the first Colorado legislature" to demonstrate the "spectacular growth and development of the

${ }^{43}$ Secretary of the Air Force Harold Talbott "insisted" that Martin build the Titan in the center of the country for this reason. John C. Lonnquest and David F. Winkler. To Defend and Deter: The Legacy of the United States Cold War Missile Program, vol. I (Champaign, Illinois, 1996), p.70.

44 "Thompson Urges Approval of US Defense Program," Guernsey Gazette, June 11, 1959, p. 6; "U.S. is far Ahead of Soviets in Military Preparedness-Curtis," The Sidney Telegraph, March 7, 1960, sec 3, p. 1. 
area during the past century." ${ }^{45}$ Indeed, where the west was once the "Last Frontier," it now regained its former glory as the home of the First Line of Defense and the missile was also associated to space, the newly designated "New Frontier." This was not unnoticed by local communities, and citizens were proud.

As the Titan was being developed, Great Plains communities were surveyed for possible missile installations. Rumors had reached Rapid City, South Dakota even before the Titan had its first successful test launch. Like in other surrounding areas, the possibility of the Titan coming to the Black Hills was seen as an opportunity for the community. ${ }^{46}$ But when the Air Force announced that Rapid City would indeed be "one of three new missile sites," reaction was mixed—not for the danger the missile posed, but because of the impact on community resources. "It is the biggest military project to date in this area," the local paper reported. It was estimated that the Titan project would need between 600 to 1000 men to run the installation, which would strain existing housing, roads, and local facilities. The emphasis of the announcement was that Rapid City was central to American security. The state was in a "key position" to aid national defense plans in the fight against Soviet aggression. The president of the city's Realtor Association welcomed the news, foreseeing the impact on residential house sales. The Atlas missile, it was assumed, was outdated, and the announcement implied that residents

45 “Titan ICBM Unveiling March 13," Wyoming State Tribune, March 1, 1959, p. 2. 46 "Chances Enhanced for Missile Base Here," Rapid City Daily Journal, January 31, 1959, p. 1. 
should feel a sense of pride that their city was chosen as the newest first line of defense technology. ${ }^{47}$

Construction of the Titan I missile was a tremendous undertaking. The Titan I was similar to the Atlas $\mathrm{F}$ in that the missile was vertically stored in a silo underground, was fueled within the silo, and launched after it was raised to the surface. But like the Atlas D, it used radio guidance, which meant that all three Titans within a complex could not be launched simultaneously. ${ }^{48}$ Also like the Atlas D, the Titan I was deployed in a $3 \times 3$ configuration (there were three missiles per LCC and three complexes per squadron) because of the radio guidance system. The Titan's flight range and speed were also similar to the Atlas D, but its CEP was cut in half to one mile-making it a much more precise weapon. ${ }^{49}$ The missile itself was larger, standing at ninety-eight feet, and its nuclear punch was increased from 1.44 megaton to four megatons. What made the Titan unique in comparison to its ICBM predecessor was the design of its launch complex: each complex was built underground making it the "largest and most expensive" ever built resembling "futuristic underground cities." ${ }^{, 50}$ These cities were reminiscent of civil

47 "Titan Missile Base Here Draws varied reactions from Officials," Rapid City Daily Journal, March 14, 1959, p. 1.

${ }^{48}$ The Titan I however, did have reduced launch times compared to the Atlas D. It took 15 minutes for the $1^{\text {st }}$ missile to launch but only $7 \frac{1 / 2}{2}$ minutes for each consecutive missile. http://www.geocities.com/titan 1 missile/

49 The Titan I flight range was 6,200 miles and its speed was 15,000 miles. CEP was 4,600 feet. Ibid.

${ }^{50}$ Each Titan I configuration was a set of three launch complexes "heavily hardened to survive a nuclear attack." They consisted of three missile silos, a control center, powerhouse, and other support facilities connected by "almost half a mile of steel 
defense complexes shown in magazines such as Life to shelter the public and manufacturing facilities in time of war.

The Titan I complexes being built at Sturgis, Hermosa, and Wicksville, South Dakota, outside of Rapid City, were described by the press as "mining operations," because of their vast size. The minimum depth was forty feet, but the silos were deep enough to "house a sixteen-story building." The Rapid City Daily Journal featured several aerial photographs of the construction site on the front page. ${ }^{51}$ Titan construction at Denver was described as "massive and delicate" because of the suspension of light fixtures, staircases, and floors to "minimize shock effects from an attack." The size of the complex was impressive: one official commented, "enough steel was used to reinforce the site to make three destroyers. The missile silos themselves extended 165 feet below the earth's surface."52 The "bird cages" were large enough to house both the missile and its umbilical cord. ${ }^{53}$ By November, sites were receiving missiles to load into the silos.

The giant Titan missile was delivered to South Dakota by airplane, and residents could not help but notice the giant. Unloading of the "huge" cargo plane was treated like

tunnel," buried under 40 feet of earth. Lonnquest and David F. Winkler. To Defend and Deter, vol. I, p.71.

${ }^{51}$ Construction was moving rapidly: the sites began in February 1960, with an expected finish date in December. "Lairs for Lethal Titan Take Shape at 3 Hills Sites," Rapid City Daily Journal, March 10, 1960, p. 1.

52 "Titan Missile Base on Schedule," Wyoming State Tribune, August 10, 1960, p. 1. The Titan I needed five crews of twelve men to operate each complex.

${ }^{53}$ Bob Fell, "Titan Site Tour . . . Underground Fortresses Are Nearing Completion," Rapid City Daily Journal, December 2, 1961, p. 1. 
a media event and was accompanied by "dozens of photographs" by both civilians and military personnel. The taxiing of the plane and the unloading of its cargo were very public affairs, but the missile's exact destination was shrouded in secrecy. The public was only told that there would be nine additional incoming missiles and they "would only be fired in the event of enemy attack." 54 But when the "birds" were ready to be placed in their "nests," it was very visible to the surrounding community. The whole process took over four hours as the two stages of the missile were placed together and fitted with a "small but deadly" thermonuclear warhead. ${ }^{55}$

The location of the Titan I complexes were no secret from those that lived nearby ${ }^{56}$ In 1961, newsmen in South Dakota were given a tour of one of the underground cities below the surface of prairie land. From the surface, there "was hardly a clue" of the "birds' nest" below. The only indication that something was buried was the three concrete doors covering the silos and an antenna, both fenced in about sixty-five acres of land. ${ }^{57}$ In all, there were a total of 54 Titan I missiles deployed, with two squadrons in Colorado, one in South Dakota, one squadron each in Washington, Idaho, and

\footnotetext{
54 "First Titan Arrives in Hills: 'Bird' Gets EAFB Check before Installation," Rapid City Daily Journal, February 5, 1961, p. 1. There was an extra missile kept in reserve.

55 "First Titan Goes into Place," Rapid City Daily Journal, February 2, 1962, p. 1. The newspaper featured three large photographs of the installation in process.

${ }^{56}$ In Wheatland, Wyoming, the two stages of the Titan I missile passed through the town in rout to the State Fair. "Titan Missile in Rout to State Fair," The Plat County Records Times, September 2, 1960, p. 1.

${ }^{57}$ Bob Fell, "Titan Site Tour . . Underground Fortresses Are Nearing Completion," Rapid City Daily Journal, December 2, 1961, p. 1.
} 
California. ${ }^{58}$ Like the Atlas missile family before it, the Titan I was activated for a very limited time: only three years. Although the first generation of ICBMs had a short life span, they continued to be important because their contribution to the Space Age.

Research on the next generation of the Titan ICBM began in 1958, as the Titan I was undergoing testing. ${ }^{59}$ The goals of the new design were to reduce costs, have launch in-silo capability, use an all-inertial guidance system, and have a $1 \times 9$ configuration. All of this was achieved with the Titan II. In addition to the above criteria, the Titan II differentiated itself from its predecessors in several ways. The all-inertial guidance system allowed the missile to be dispersed at least seven miles apart from each other for protection against a nuclear blast and the sites had increased hardness. ${ }^{60}$ Its most distinct feature was storable propellants. Storable liquid fuel meant that the Titan II could be fueled and waiting, therefore reducing launch time to a mere sixty seconds. The Titan II was also a bigger missile with the most powerful warhead deployed on an ICBM to date. It was 103 feet tall, had a maximum speed of 15,000 miles per hour, and packed a powerful punch: its warhead had a yield of nine megatons. Unlike its predecessors, the

${ }^{58}$ The other 3 squadrons were in California, Washington, and Idaho. The limited flight range of the Titan restricted its deployment.

${ }^{59}$ At the time, the Titan II was considered a second-generation missile. But when the Minuteman was developed using solid fuel, it was declared a second-generation ICBM. The Titan II had several revolutionary changes, however, that made it distinct and the Minuteman possible. Therefore, it would not be inaccurate to label the Titan II ICBM intermediate-generation.

${ }^{60}$ The silo door was made from 740 tons of steel and concrete and was designed to have an overpressure of 1000 psi. Despite its weight and strength, the door was able to spring open in twenty seconds or less, adding to the quick reaction time of the missile. http://www.techbastard.com/missile/titan2/index.php 
Titan II was on active duty for twenty-four years and was central to missile defense. ${ }^{61}$ They were activated October of 1963 and deactivated in October 1987. The Titan II was the most powerful weapon, and its design successfully overcame pervious missile glitches, but the search for the ultimate weapon continued.

Development of the Minuteman began in 1958—concurrent with the development of the Titan II. A true second generation missile, reliant on solid storable fuel, the Minuteman made evident early-on that first generation missiles would be quickly outdated. As Time noted, "they doomed to swift obsolescence the cumbersome, complex, costly, 'first-generation' liquid-fueled missiles, with their big, liquid-oxygen plants, their long fueling time before launching and their intricate plumbing." ${ }^{, 62}$ It was reported that the solid fueled missile would accelerate the phasing out of both the first generation missiles and the manned bomber. ${ }^{63}$ Development progressed so quickly with the new missile that even as it was being tested, plans were being finalized for its deployment.

The Minuteman missile was seen by many to be the ultimate deterrent and the solution to the "missile gap." 64 The Air Force intended for the missile to be mobile.

${ }^{61}$ The Titan II was the most powerful missile in the American arsenal. The Minuteman III and Peacekeeper would come close to its power with the possession of MIRVs (multiple independently targetable reentry vehicles), but no other missile would be able to deliver 10 megatons to a single destination.

62 "Defense: The Second Generation," Time, March 10, 1958, p. 16.

${ }^{63}$ Harold H. Martin, "Our New Generation of Rockets," Saturday Evening Post, October 1, 1960, pp. 28-29.

64 "The Coming Missile Gap: Power in the Bomb Bays; Trouble on the Pads," Time, February 8, 1960, p. 18. 
Mounted and able to launch on railway cars, it was believed that the Minuteman would have no rival. Americans were assured that a mobile missile fleet would "keep the Russians guessing" and protect the nation by keeping its retaliatory forces "immune from a surprise knockout blow." ${ }^{65}$ To test the Minuteman's mobility, the Air Force recruited the Union Pacific Railroad in Wyoming and roamed from the Midwest to the Far West. ${ }^{66}$ Although the trains appeared to be traveling at random, they were actually under close direction from SAC and testing began in mid-1960. ${ }^{67}$ Missile mobility itself was a new concept, but for the Air Force, it was an extension of its protection principal. Missiles had been hardened and dispersed, and a percentage of SAC planes were always airborne (mobile). To make the ultimate weapon mobile would also ensure its safety and add to its deterrent capability. ${ }^{68}$ Mobility, however, would not work for the Minuteman: it was costly and unforeseen in its initial design period, rails made the missile vulnerable to

65 "Minuteman Missile Test Run Under Way," Wyoming State Tribune, June 19, 1960, p. 1; "SAC Will get Trains for Roaming Missile Launchers," Wyoming State Tribune, February 9, 1960, p. 1.

${ }^{66}$ In addition to the Union Pacific Railroad, the Air Force used the Chicago, Burlington, and Quincy. "Wyoming to be Included in Missile Tests," Wyoming State Triune, May 13,1960 , p. 2. The test program called for the missile train to operate in and through Wyoming, Nebraska, South Dakota, Minnesota, Wisconsin, Iowa, Missouri, Illinois, Oregon, Washington, Idaho, and California. "14 Railroads in Tests for Minuteman," Wyoming State Tribune, June 1, 1960, p. 2.

67 "Minuteman Rail Tests Under Way," Wyoming State Tribune, June 20, 1960, p. 1; "Second Minuteman Missile tests Begin," Wyoming State Tribune, July 7, 1960, p. 1. The Wyoming State Tribune printed an artistic illustration of what the mobile Minuteman would look like. "The Missile Train," Wyoming State Tribune, September 1, 1960, p. 1.

68 "Moving Minuteman Missiles by Train Across Country," Pine Bluffs Post, December 29,1960, p. 1. 
enemy attack. ${ }^{69}$ Instead, the ICBM was hidden in the ground and perceived as America's "ace in the hole."

The Minuteman was different from all of its predecessors for several reasons: it was the first mass-produced missile-making it relatively cheap in comparison to the Atlas and Titan. It used solid storable fuel, it was a three-stage missile, and it was smaller and lighter than its predecessors. ${ }^{70}$ It was only capable of carrying a one-megaton warhead, but the Minuteman was extremely accurate with a CEP of 1.5 miles. It's assembly-line construction allowed the missile to be produced in quantity quickly. These differences are important because they demonstrate the changed technology: the new missiles were cheap, easily dispersed in pre-fabricated silos, able to be scattered all over the Plains with virtually no one monitoring them, and they operational by remote pushbutton design. As one reporter noted, "the Minuteman is essentially a target saturation weapon [able to] set off like a Roman candle."71 The Air Force originally planned to have one thousand nested throughout the Great Plains. The Cold War geography of the Great Plains transformed from a remote countryside with few carefully placed military installations to an area congested with nearly invisible missile complexes. And just as the

${ }^{69}$ Elbert E. (Sonny) Witt, Deputy Commander at Cape Canaveral Air Force Station, Interview by Jessica Barrella, Cape Canaveral, Florida, April 25, 2006.

${ }^{70}$ The Minuteman IA was 53' 8"' and the Minuteman 1B was 55' 11"; its range was between $6,000-6,300$ miles with a speed of $15,000 \mathrm{mph}$.

http://www.geocities.com/minuteman_missile/index.html

${ }^{71}$ Rem Price, "Minuteman Can Pave way to Saturation Type Attack," Rapid City Daily Journal, November 27, 1960, p. 4. 
Minuteman was intended to be a "saturation weapon," it was equally designed to absorb an enemy first-strike.

There were ten missiles (launch facility) per each launch control facility and five launch facilities per squadron (equaling 50 missiles). Each was connected by underground cables, but separated from the other with enough room to absorb a tenmegaton blast without affecting a neighboring launch facility. This separation also assured that multiple sites could not be targeted together. ${ }^{72}$ The Minuteman could be stored for a long period of time with very little maintenance, and it could be launched almost immediately by simply pushing a button—operated by "remote control." Only two men were needed to monitor ten missiles. Indeed, the Minuteman was the first instantaneous missile in the U.S. arsenal.

The first home for the Minuteman missile was Montana, and digging began in March 1961, but neighboring states were paying close attention. The missiles were widely dispersed in vast numbers, and for that reason the Air Force needed large amounts of land for each squadron - in Montana, alone, Minutemen were scattered over 20,000 square miles of land. Eventually the missiles were nested throughout the Great Plains. ${ }^{73}$ The center of the nation had become saturated with potential Soviet targets.

${ }^{72}$ http://www.cr.nps.gov/history/online books/mimi/hrs2-3.htm

${ }^{73}$ The Minuteman I, II, and III were housed in California, Colorado, Wyoming, Montana, Nebraska, North and South Dakota, and Missouri. John C. Lonnquest and David F. Winkler. To Defend and Deter, vol. II, pp. 579-581. Because there would be so many missiles, communities were concerned about accidental explosion, but again they were assured that it could not happen. "Minuteman Stands Guard . . . Mighty Missile in a Tiny Shell has Big Part in U.S. Defenses," Sidney Telegraph, August 29, 1962, p. 1. 
Surprisingly, most people did not see that saturating the Plains with missiles would increase their vulnerability to Soviet attack, and press reports were conflicting. Newspapers reported a missile gap, argued American nuclear weapons were "outdated," and noted that the United States Air Force was going to reduce the size of its wing strength. ${ }^{74}$ The conflicting information of national security and the international Soviet threat contributed city residents' acceptance of ICBMs in and near their communities, and most associated missiles with economic prosperity and patriotic duty. Wyoming wanted and appealed for a Minuteman base, and eventually got one. ${ }^{75}$ The Nebraskan panhandle was also eager to be chosen as a site for the new missile, and information about the Minuteman made front-page news almost daily. ${ }^{76}$ The area was not selected to

74 "Russ Defense Boss: Nuclear Arms Outdated," Rapid City Daily Journal, February 3, 1959, p. 1; "McElroy Sees Close in Missile Gap," Rapid City Daily Journal, February 4, 1959, p. 2; Elton C. Fay, "USAF May Cut to 90 Wings or Less," Rapid City Daily Journal, February 9, 1959, p. 1.

${ }^{75}$ George Johnston, "Wyoming Seeks Minuteman Base," The Wyoming Eagle, March 29, 1961, p. 1; "Mayor Story Says: WAB 'Still in Running' for Minuteman Base," The Wyoming Eagle, March 30, 1961, p. 1. When the state was selected and bidding began, "several thousands" of people were expected in Cheyenne for four to seven days, and welcomed the men with a full-page advertisement. James M. Flinchum, "Bidding Opening Here Oct. 11," Wyoming State Tribune, September 30, 1962, p. 1; "200-Silo Contract to be Let," The Wyoming Eagle, October 11, 1962, p. 1; "Welcome to Cheyenne," Advertisement, The Wyoming Eagle, October 11, 1962, p. 20.

76 “Air Force is Surveying Area for Missile Sites," Sidney Telegraph, January 19, 1962, p. 1; "This is the Minuteman," Sidney Telegraph, February 16, 1962, p. 1; "Missiles Become Operational in 1962, Constitute Backbone of Nation," Sidney Telegraph, February 22, 1962, p. 1; "Minuteman Decision May Come By March 15," Sidney Telegraph, March 7, 1962, p. 1; "Survey for Minuteman Missile Site Extends into Garden and Duel," Sidney Telegraph, March 23, 1962, p. 1. 
house the new Minuteman, but Kimball and Sidney were chosen as construction support areas. ${ }^{77}$ Nevertheless, residents were pleased. ${ }^{78}$

Speculation that the Minuteman would be placed in South Dakota started when the Army Corps of Engineers began to conduct soil tests in October 1960. Many were concerned about the sluggish construction of the Titan missile complexes and hoped that the new missile would invigorate the job market. Indeed, when South Dakota was announced for the next installation, employment did increase. ${ }^{79}$ Minuteman construction contributed to the local economy, but also began to place local residents in conflict with the government.

77 "Construction Boom is Expected In Minuteman Missile Support Area," Sidney Telegraph, March 28, 1962, p. 1. Construction support areas were dispatch centers serving a field management headquarters "during the launch facility and construction phase and for weapons systems assembly and checkout." "Minuteman Bids Set in September; 200 Launching Sites are Located in Corner of Three-State Region," Sidney Telegraph, June 15, 1962, p. 1.

78 "Sioux Depot Slated to be Important Center for Minuteman Missile Construction Phase," Sidney Telegraph, May 18, 1962, p. 1.

${ }^{79}$ The Titan complexes were still being constructed while Minuteman sites were being chosen. "Minuteman Timetable Mulled by Committee," Rapid City Daily Journal, May 25, 1961, p. 3; "Minuteman Missile Schedule Here Revealed: 1900 To Be Employed Boeing Official States," Rapid City Daily Journal, June 14, 1961, p. 3. Boeing announced that $20 \%$ of its estimated work force would be locals. In Wyoming, an estimated $80 \%$ of the Minuteman workforce was hired locally. "M-K to Hire 2,000 on Minuteman Job," Wyoming State Tribune, October 17, 1962, p. 1.

The increased workforce in South Dakota was "a vicious cycle" because there was not enough housing for the influx of workers. "Defense Program Brings Housing," Rapid City Daily Journal, August 4, 1961, p. 1; "Minuteman Missile project Explained to Residents Here," Pine Bluffs Post, September 7, 1961, p. 1. Contractors new to the area advertised the need for homes in the local newspaper. "Minuteman Project," Rapid City Daily Journal, Classifieds, September 22, 1961, p. 21. 
The Army Corps of Engineers negotiated with residents and told them what to expect with land acquisition procedures. ${ }^{80}$ According to the Platt County Record Times of Southeastern Wyoming, the Corps stated that there would only be two acres of land needed, "and a simple title will be gotten." There would also be need for easements for construction, "line of site," and cable installation. The later could be regressed or used for "agricultural or grazing around the site and within the restricted area." To appeal to rural residents, it was also stated that the government would fund and maintain access roads. In addition, the government would improve county roads to "aid in the hauling of heavy equipment" but would also provide "much better roads" for farmers and ranchers "then they had previously." "81 Several months later, the district engineer for the Army Corps of Engineers held a meeting for "all property owners affected by the missile program." He commended the people of Wyoming, Nebraska, and Colorado for "helping to carry out the national defense program." ${ }^{\text {"I }}$ It is telling that the residents of South Dakota were not mentioned or included in his thanks. Over one hundred ranchers in that state questioned Army Corps of Engineer land acquisition tactics and were not as accommodating as residents in neighboring states in signing "right-of-way" contracts.

80 "Minuteman Missile Base to be Explained at Meet," Pine Bluffs Post, July 20, 1961, p. 1.

81 "Land Purchases to Start Soon on Minute Man Sites," Platt County Record Times, July 20, 1962, p. 1.

82739 property owners and about 100 tenants "voluntarily granted the government the right to commence construction" on their land, totaling about $40 \%$ of the land needed for construction. "Missile Program Meeting Scheduled," Platt County Record Times, October 19, 1962, p. 1. 
Ranchers in the proposed South Dakota Minuteman area organized to obtain more control over land values and easement agreements. Consisting of almost one hundred fifty members, they called themselves the Minuteman Missile Landowners Association (MALA). Questions about land acquisition procedures began in 1960 when soil samples were being taken and before final announcement of Minuteman placement in South Dakota. Rancher Leonel Jensen (MALA member) wrote a letter to Senator Francis Case with concerns about missile placement on his property. He was not "objectionable" to having a missile on his land, but questioned the location itself. The land chosen was some of his best and was "almost in the center of the ranch." He continued, "To have an installation there would be a terrific imposition on our routine way of life and would materially inconvenience us in many ways." Jensen was willing to work with the government, but could not understand why the government was not willing to work with him:

We have five thousand acres in the ranch and we have plenty of places where a defense installation would not be objectionable. There are many places that are just as accessible or in my opinion more so then this one and we would be happy to contribute our small share to any defense measure but we cannot quite see the practicality or the fairness of the Defense Command just plotting on a map where the base should be and just putting it there.

Is there any reason why an equitable survey with the land owner and a representative of the Defense Command and a site picked that would be less detrimental to the land owner. ${ }^{83}$

83 "Letter from Leonel M. Jensen to Senator Francis Case, November 16, 1960," South Dakota State Archive, Collection H94-18, Minuteman II Missile Site, Box 5720B, Folder: Correspondence, 1960-1961. By the end of the year, The Air Force had agreed to change the missile location site on Jensen's land. "Letter from General Thomas Power, USAF, to Senator Francis Case, December 1960, "South Dakota State Archive, Collection H94-18, Minuteman II Missile Site, Box 5720B, Folder: Correspondence, 1960-1961. 
In addition to the above concerns, MALA believed that a missile located on a ranch or farm would decrease the resale value and they wanted easement forms to reflect this. ${ }^{84}$ Ranchers and farmers did get a sympathetic ear from Senator Case. The Senator assisted with negotiations between MALA, Army Corps of Engineers, and Air Force officials, but negotiations were slow going.

By April 1961, it was announced that the Minuteman Project was going to be accelerated, and members from the Army Corps of Engineers and the Air Force repeatedly met with landowners to answer questions and quell concerns. Attendees felt that the government was not adequately reimbursing landowners, especially in light of grants made to large corporations and salaries given to temporary unskilled laborers employed at missile sites. ${ }^{85}$ At one meeting, Eugene Pellegrin, MALA president, asked what would happen if landowners did not sign the "right-of-way" construction agreement. The government had two choices in obtaining private land, it was explained: voluntary or court order. As was mentioned in the Rapid City Daily Journal, that however "distasteful" condemnation was, it has been used before and would be used again. ${ }^{86}$ Members felt that they were being coerced into signing land acquisition forms

84 "Preface to Proposals ... Land Owners Talk Missile Site Values," Rapid City Daily Journal, March 23, 1961, p. 1.

${ }^{85}$ Don Glerup, “ 'Little People' Seem 10 Feet Tall to Engineers at Meeting," Pierre State News, October 13, 1961, p. 5.

${ }^{86}$ Dick Rebbeck, "Landowners Told: Missiles Can't Wait," Rapid City Daily Journal, April 5, 1961, p. 1. Wording of right-of-entry agreements was a major concern for MALA members and Pellegrin tried to negotiate verbiage with the understanding that members would sign more readily. Some landowners did pursue condemnation hearings 
and easement agreements because engineer representatives were giving false information about the number of landowners who signed the agreement. ${ }^{87}$

Area residents were sympathetic with MALA concerns, but as issues continued unresolved, many began to loose their patience. As a result, MALA members were reflected in the local newspaper as unpatriotic and greedy. One editorial regarded MALA demands as selfish in light of "the hot breath of the Russians in the race for space and for supremacy on this globe. ${ }^{" 88}$ Local newspapers made residents keenly aware that being cooperative with the Corps of Engineers was a small but important part of public participation in national defense. Underscoring most articles concerning MALA was the lack of patriotism demonstrated by members. Landowners countered that they were not being greedy: they simply wanted a clearly written agreement without surrendering their rights. Eventually most of the Minuteman Missile Area Landowners Association's conditions were met and they agreed to sign right-of-entry forms and easement agreements. ${ }^{89}$ By July 1963, there were one hundred fifty Minuteman missiles on

with the belief that legal proceedings were a fair and just way to resolve compensation issues. "Fair treatment Cited in Missile Condemnations," Rapid City Daily Journal, September 13, 1961, p. 3.

87 "Talk at the Hearing Before the Corps of Engineers, Rapid City," Undated, South Dakota State Archive, Collection H94-18, Minuteman II Missile Site, Box 5720B, Folder: Correspondence, 1960-1961.

88 "The Inconvenience of Missile Sites," Editorial, Sioux Falls Argus-Leader, Undated, South Dakota State Archive, Collection H94-18, Minuteman II Missile Site, Box 5720B, Folder: Correspondence, 1960-1961.

${ }^{89}$ Senator Case was most cooperative with MALA and negotiated to have their demands met. He was in constant correspondence with the Association via phone and post. Landowners continued to be in contact with the Corps of Engineers after the missiles 
operational alert nationwide. That number doubled by October 1963, and tripled by March 1964. In mid-1965 the 800th Minuteman I missile was turned over to SAC. ${ }^{90}$ Although providing increased deterrence, rapid missile advancement had its disadvantages: regional targetability, an increased civilian defense emphasis, and fallout contamination concerns.

As missiles were being planted in the interior of the United States, their presence in communities made residents acutely aware that their small towns were added to Russia's list of American "primary targets." When Atlas sites were activated around Cheyenne, mayors met to discuss the elevated status of their cities. Although trust in the Air force was high, "target-town heads" did not feel elated about being in the Soviet sights. ${ }^{91}$ As more missiles were deployed, concerns about the vulnerability of cities increased. One Montana resident called the Minuteman sites a "menace." "92 Another missile neighbor questioned the logic of residents in accepting this fate: "I puzzle over the illogical complacency of most urban citizens of the rocky Mountain West while

were built. Landowners were responsible for reporting damage to the missile site, and in some cases needed to make repairs themselves. Jensen corresponded with the Army several times to report damages and receive compensation. South Dakota State Archive, Collection H94-18, Minuteman II Missile Site, Box 5720B, Folder: Correspondence, Arguments, Maps, 1962-1964.

${ }^{90} \mathrm{http}: / /$ www.strategic-aircommand.com/missiles/Minuteman/Minuteman Missile_History.htm

91 "Mayors Comment on Missile Bases: 'Target-Town Heads' Express Feelings," Wyoming State Tribune, August 4, 1959, p. 1.

92 "Montanan Says Minuteman Sites Are a Menace," Rapid City Daily Journal, May 9 , 1962, p. 24. 
ICBM bases are built practically in their backyards." There is so much land in this country, "yet we are crowding our ICBM bases into the biggest target areas in this spottily inhabited part of our country, around cities that usually lie in our most productive agricultural valleys," he continued. Those who encouraged missile deployment in their communities were "shortsighted" because they making their communities "primary atomic war targets." ${ }^{93}$ But as MALA demonstrated, there was little that could be done to deter the federal government. One reporter in Nebraska explained, once all the missiles are in their nests, "you probably wont be aware that you are living right it the mists of one of the most terrifying and destructive striking forces ever devised for the defense of any people." ${ }^{94}$ Missile fortifications were a reminder to local communities that residents needed to be protected as well, and civil defense became a central concern among communities in the Great Plains.

Residents of Nebraska, Wyoming, and South Dakota were aware that the nuclear force nested in the ground made their once small and safe communities Soviet targets. This knowledge gave civil defense added importance: many communities had air-raid sirens, tagged their children, built shelters, and participated regularly in local and national civil defense drills. Their vulnerability was made more apparent when it was declared that the United States had more to fear from nuclear fallout than any other nation. This was underscored when a family of sheepherders in Wyoming sued the government over

93 Cresson H. Kearney, "Sitting of ICBM Bases," Letters to the Editor, Bulletin of Atomic Scientists (December 1960), p. 63.

94 "Minuteman Stands Guard . . . Mighty Missile in a Tiny Shell has Big Part in U.S. Defenses," Sidney Telegraph, August 29, 1962, p. 1. 
fallout contamination from nuclear testing to themselves and their livestock. Although the AEC claimed the accusation was false and the family did not win any compensation from the federal government, the news made front-page headlines as the story developed. ${ }^{95}$ The government and the AEC did not claim responsibility for the death of the rancher's sheep or the injury caused to his family, but locals were keenly aware that fallout was a real danger and preparation was the key to survival. Like the federal government, local communities were hoping for peace but preparing for war.

Many procedures used to protect civilians in time of war were incorporated into missile fortifications. The Atlas D was unhardened and exposed, but the $\mathrm{E}$ was protected from an enemy attack by dispersal. The Titan I sites were built to withstand a nuclear attack: they were hardened under-ground structures with support facilities-very much built like the shelters suggesting for families. The Titan II had its own survival city beneath the ground and the Minuteman was fortified and dispersed for protection. The Air Force even recruited "vehicle spotters" as additional protection for the remote locations of Minuteman installations. Civilian vehicle spotters were similar to enemy

95 "U.S. Has More to Fear from Fallout than Other Nations," Wyoming State Tribune, May 6, 1959, p. 1. "Rancher says 126 Sheep Died: Radioactivity Blamed in \$1 Million Suit," The Wyoming Eagle, April 22, 1961, p. 1; "Tests Fail to Disclose Radiation," Wyoming State Tribune, April 23, 1961, p. 1; "AEC Silent on Ranch Family's Damage Suit," The Wyoming Eagle, April 25, 1961, p. 4; Dick Rebbeck, "Wyoming Family's Radiation Suit Offers Grim Picture of Atom Age," Rapid City Daily Journal, June 14, 1961, p. 1; "Government Denies Charges in Radioactivity Suit," The Wyoming Eagle, June 16, 1961, p. 1. 
plane spotters of the Ground Observer Corps-but they worked voluntarily rather than in shifts. The spotter called the local AFB if anything looked suspicious or needed repair. ${ }^{96}$

The intercontinental ballistic missile went through a series of changes: from the unhardened and clustered Atlas D with a 1.44 megaton warhead, to the one megaton Titan I, a virtual city nested below the ground, to the Minuteman, a smaller, more compact weapon with less punch, but mass-produced and nested under great tracts of land throughout the American Great Plains. Concurrency helped each succeeding missile became better suited to deter the threat of the enemy. Like civil defense procedures of the time, ICBM developers also tried to keep abreast of the latest defense technologyshelter and dispersal. Missile technology, however, was advancing so quickly that even engineers and contractors could not keep pace. As the ultimate weapon advanced they became more numerous and the Air Force and Army Corps of Engineers had a more difficult time acquiring land to bury the missile and keeping their location confidential. Concessions needed to be made to assure the public of their safety, but the public had to make compromises also: missiles were planted in their backyard to protect the nation from enemy attack, but the very location of the missiles made their cities enemy targets.

\footnotetext{
${ }^{96}$ Leonel Jensen became a vehicle spotter. "Vehicle Spotter," Undated, South Dakota State Archive, Collection H94-18, Minuteman II Missile Site, Box 5720B, Folder: Correspondence, Arguments, Maps, 1962-1964.
} 


\section{Conclusion}

Missiles changed the real and perceived landscape of the United States. Boarders were shifted, land was moved, and cities were transformed. Until this time, history had taught Americans to view their world in conventional terms of direction (north, south, east, and west). But the technology that accompanied missile systems extended to a nontraditional direction: up. Soviet satellites were propagated as spy machines capable of penetrating all protective shields. Their presence assured national security but also revealed the nation's vulnerabilities. In addition, missiles were used for peaceful reasons: space exploration. Without the missile, the Space Age would have been impossible. Cities around the country clamored for missiles to be placed in their communities for both the prestige it would bring to the region and the government money that would accompany the project. But as we have also seen, not everyone agreed with missile development and deployment. Fears of new technology were the primary culprit, but there were also personal concerns, such as adequate compensation and treatment of workers. Countering these views was patriotism: increasingly to Americans at the time, the missile in the United States began to symbolize democracy. This was just one of the many paradoxes of the missile.

Traditionally, missile history has been one-dimensional, focusing on administrative, technological, or vertical missile history with little account of the external outside forces that impacted its story. Past historians have limited their research by staying within the boundaries of the missile itself. This study has taken a more dynamic approach by examining the missile from the outside looking in. By evaluating external aspects such as security, cultural understandings and the impact on the landscape we are 
better able to understand how the missile changed American society and culture. But its effects cannot always be labeled as tangible. The creation of the missile brought to the surface many abstract concerns that could not be otherwise seen or understood within the traditional boundaries of missile history.

The impact of the missile during its formative years can be broken down into two general categories: technological impact and landscape transformation. The technological impact of the missile goes beyond missile technology: it is how Americans perceived emerging technologies associated with missile development and how these changes helped shape their understanding of the Cold War. New defense measures were developed simultaneously to make the missile more effective and to assure national security. But just as they were developed to protect, they were also developed to destroy. In addition, there was the possibility of human error and computer malfunction—on both sides of the Iron Curtain.

The missile also transformed the landscape. New technologies extended American's understanding of boundaries and boarders, but the appearance of missiles themselves changed both the real and perceived landscape. In the early years of the ICBM, missiles stood sentinel above ground, but each phase of missile development buried them deeper into the earth, until they were completely obstructed from view. American perceptions, although not necessarily tangible and unable to be physically measured, are very important to understand how the missile impacted American socially and culturally. Both the real and perceived landscape included outer space and negative space. Missiles were buried underground, but Americans were very much aware of their 
presence. The negative space of the Great Plains was a bed of hidden activity, blurring the American understanding of safety.

Moreover these two categories can be further dissected to include intangible effects such as security and protection, dangers, doubts, and fears. The secrecy that surrounded nuclear weapons also cloaked missile development. The two weapons linked together generated a new dialogue, which seeped into all aspects of American life, and forced the public to face the unknown.

The missile helped shape how the United States and the Soviet Union fought the Cold War. Instantaneous attack and massive retaliation from nations across the globe made the world realize that the next war would not only be total but could also be final: the missile topped with thermonuclear weapons had the ability to destroy the world. The ICBM made humans realize the finality of their existence on earth, but it also opened the galaxy for exploration, transforming its focus to peaceful means. Little credit has been given to the "ultimate weapon" in American history. It helped shape national and foreign policy, expanded cities and created underground fortresses, made the Space Age possible, and forced humans to face their mortality in a perilous world. 


\section{BIBLIOGRAPHY}

\section{ARCHIVES:}

Parent-Teachers Association Archive, Chicago, Illinois Kennedy Space Center Archive, Cape Canaveral, Florida

Minuteman Missile National Historical Site, National Park Service, Philip, South Dakota South Dakota State Archives, Pierre, South Dakota Warren ICBM and Heritage Museum, F.E. Warren AFB, Cheyenne, Wyoming Wyoming State Archives, Cheyenne, Wyoming

\section{ADDITIONAL SITES:}

The Home of Dan and Charlene Zwonitzer, owners of a converted Atlas D Missile installation

The Nike Historical Society, San Francisco, California

\section{INTERVIEWS:}

\section{Conducted by Jessica Barrella:}

Don Zwonitzer, October 2, 2006, Kimball, Nebraska

Al Kellogg, July 16, 2006, San Francisco, California

Ezio F. Nurisio, July 16, 2006, San Francisco, California

John G. Lunn, July 16, 2006, San Francisco, California; July 27, 2006, by telephone

Ronald W. Parshall, July, 14 and 16, 2006, San Francisco, California

Elbert E. (Sonny) Witt, April 25, 2006, Cape Canaveral Air Force Station, Florida

\section{NEWSPAPERS:}

Cocoa Tribune, Florida

Guernsey Gazette, Wyoming

Pine Bluffs Post, Wyoming

Platt County Record Times, Wyoming

Rapid City Daily Journal, South Dakota

San Francisco Chronicle

San Francisco Examiner

San Francisco News

Sidney Telegraph, Nebraska

Titusville Star-Advocate, Florida

Western Nebraska Observer

Wheatland Times, Wyoming

Wyoming Eagle

Wyoming State Tribune 


\section{MAGAZINES AND JOURNALS:}

Air Power History

Air \& Space Smithsonian

Bulletin of Atomic Scientists

The Economist

Fortune

Harper's Magazine

High Frontier

Life

Military Affairs

Nation

The Reader's Digest

National Parent-Teacher: The PTA Magazine

New Republic

The Saturday Evening Post

Newsweek

New York Times Book Review

New York Times Magazine

Parenting Magazine

Public Opinion Quarterly

Time

U.S. News and World Report

\section{GOVERNMENT DOCUMENTS:}

Department of Agriculture. Family Food Stockpile for Survival. 1961.

Department of Defense: Office of Civil Defense. In Time of Emergency: A Citizen's Handbook on Nuclear Attack, Natural Disasters. March 1968.

Department of Defense: Office of Civil Defense. Personal and Family Survival: Civil Defense Adult Education Course Student Manual. November 1966.

Department of Defense: Office of Civil Defense. Family Shelter Designs. January 1962.

Department of Defense: Office of Civil Defense. Fallout Protection: What to Know and Do About Nuclear Fallout. December 1961.

Department of Defense: Office of Civil Defense. Home Protection Exercises. July 1960.

Department of Defense: Office of Civil Defense. First Aid. June 1960.

Department of Health, Education, and Welfare. Civil Defense Education Newsletter. February 1960. 
Golden Gate National Park Association. "Nike Missile Site SF-88." 1999.

Mitchell, Donald W. Civil Defense: Planning for Survival and Recovery. Washington, D.C.: Industrial College of the Armed Forces, 1962.

Office of Civil and Defense Mobilization. Facts About Fallout Protection, April 1958.

Office of Civil and Defense Mobilization. Handbook for Emergencies. August 1958.

Public Papers of the Presidents of the United States, Dwight D. Eisenhower, 1957. Washington, D.C.: GPO, 1958.

Public Papers of the Presidents of the United States, Dwight D. Eisenhower, 1956. Washington, D.C.: GPO, 1958.

United States. Department of State. Foreign Relations of the United States, 1961-1963, Vol. 8: National Security Policy. Washington D.C. Government Printing Office, 1996.

United States. Department of State. Foreign Relations of the United States, 1955-1957, Vol. 19: National Security Policy. Washington D.C. Government Printing Office, 1990.

United States. Department of State. Foreign Relations of the United States, 1955-1957, Vol. 24: Soviet Union; Eastern Mediterranean. Washington D.C. Government Printing Office, 1989.

United States. Department of State. Foreign Relations of the United States, 1952-1954, Vol. 2, Part 1: National Security Affairs. Washington D.C. Government Printing Office. 1984.

United States. Department of State. Foreign Relations of the United States, 1952-1954, Vol. 2, Part 2: National Security Policy. Washington D.C. Government Printing Office. 1984.

United States. Department of State. Foreign Relations of the United States, 1952-1954, Vol. 6, Part 2: Western Europe and Canada. 1986.

U.S. Congress. Senate. "A Study of Policies to Reduce the Danger of Accidental War in the 1960s," Proceedings and Debates. $86^{\text {th }}$ Congress, $2^{\text {nd }}$ sess., Congressional Record (August 12, 1960), vol. 106, pt. 12.

U.S. Congress. House. Representative Porter of Oregon speaking about "War by Miscalculation." Proceedings and Debates. $86^{\text {th }}$ Congress, $2^{\text {nd }}$ sess., Congressional Record (March 31, 1960), vol. 106, pt. 6. 


\section{BOOKS:}

Abbate, Janet. Inventing the Internet. Cambridge: The MIT Press, 1999.

Alkon, Paul K. Science Fiction Before 1900: Imagination Discovers Technology. Routledge: New York, 2002.

Ambrose, Stephen E. Eisenhower: Soldier and President. New York: Simon \& Schuster, 1990.

Baker, David. The Rocket: The History and Development of Rocket \& Missile Technology. New York: Crown Publishers, Inc., 1978.

Beard, Edmond. Developing the ICBM: A Study in Bureaucratic Politics. New York: Columbia University Press, 1976.

Benson, Charles D. and William Barnaby Faherty. Moonport: A History of Apollo Launch Facilities and Operations. Washington D.C., NASA: 1978.

Berg, A. Scott. Lindbergh. G.P. Putnam's Sons: New York, 1998.

Bergaust, Erik. Rocket City U.S.A.: From Huntsville, Alabama, to the Moon. New York: The Macmillan Company, 1963.

Berhow, Mark A. U.S. Strategic and Defensive Missile Systems, 1950-2004. University Park, Illinois: Osprey Press, 2005.

Bilstein, Roger E. Flight in America: From the Wrights to the Astronauts. rev. ed. Baltimore: The John Hopkins University Press, 1994.

Bird, Kai and Martin J. Sherwin. American Prometheus: The Triumph and Tragedy of J. Robert Oppenheimer. New York: Alfred A Knopf, 2005.

Borgiasz, William S. The Strategic Air Command: Evolution and Consolidation of Nuclear Forces, 1945-1955. Westport, Connecticut: Praeger, 1996.

The Book Review Digest. March 1963 to February 1964 Inclusive. New York: The H. W. Wilson Company, 1964

The Book Review Digest. March 1962 to February 1963 Inclusive. New York: The H. W. Wilson Company, 1963.

The Book Review Digest. March 1960 to February 1961 Inclusive. New York: The H. W. Wilson Company, 1961 
The Book Review Digest. March 1959 to February 1960 Inclusive. New York: The H. W. Wilson Company, 1960.

The Book Review Digest. March 1957 to February 1958 Inclusive. New York: The H. W. Wilson Company, 1958.

The Book Review Digest. March 1954 to February 1955 Inclusive. New York: The H.W. Wilson Company, 1955.

Boyer, Paul. Fallout: A Historian Reflects on America's Half-Century Encounter with Nuclear Weapons. Columbus: Ohio States University Press, 1988.

Boyer, Paul. By the Bomb's Early Light: American Thought and Culture at the dawning of the Atomic Age, $2^{\text {nd }}$ ed. Chapel Hill: University of North Carolina Press, 1994.

Brodie, Bernard. Strategy in the Missile Age. Princeton: Princeton University Press, 1959.

Bryant, Peter. Red Alert. New York: Ace Books, Inc., 1958.

Burdick, Eugene, and Harvey Wheeler. Fail-Safe. New York: McGraw-Hill Book Company, 1962.

Carlson, Christina M. and Robert Lyon. Last Line of Defense: Nike Missile Sites in Illinois. Denver: National Park Service, Rocky Mountain System Support Office, 1996.

Carter, Paul A. The Creation of Tomorrow: Fifty Years of Magazine Science Fiction. Columbia University Press: New York, 1977.

Chun, Clayton K.S. Thunder Over the Horizon: From V-2 Rockets to Ballistic Missiles. Westport, Connecticut: Praeger Security International, 2006.

Collins, Martin J. Cold War Laboratory: RAND, the Air Force, and the American State, 1945-1950. Washington: Smithsonian Institution Press, 2002.

Costello, Peter. Jules Verne: Inventor of Science Fiction. Charles Scribner's Sons: New York, 1978.

Crouch, Tom D. Aiming for the Stars: The Dreamers and the Doers of the Space Age. Washington D.C.: Smithsonian Institute Press, 1999.

Davis, Elmer. Two Minutes Till Midnight. New York: The Bobbs-Merrill Company, Inc., 1955. 
Day, Jr., Samuel H., ed. Nuclear Heartland: A Guide to the 1000 missile Silos in the United States. A Nukewatch Book, The Progressive Foundation: Madison, 1988.

Divine, Robert A. The Sputnik Challenge. New York: Oxford University Press, 1993.

Divine, Robert A. Blowing on the Wind: The Nuclear Test Ban Debate, 1954-1960. Oxford University Press: New York, 1978.

Dockrill, Saki. Eisenhower's New-Look National Security Policy, 1953-61. New York: St. Martin's Press, Inc., 1996

Dreher, Carl. Automation: What it Is, How it Works, Who can Use It. New York: Marzani \& Munsell, 1957.

Dunn, David H. The Politics of Threat: Minuteman Vulnerability in American National National Security Policy. New York: St. Martin's Press, Inc., 1997.

Eisenhower, Dwight D. The White House Years: Mandate for Change, 1953-1956.

Garden City, New York: Doubleday \& Company, Inc., 1963.

Eisenhower, Dwight D. The White House Years: Waging Peace, 1956-1961.

Garden City, New York: Doubleday \& Company, Inc., 1965.

Edwards, Paul N. The Closed World: Computers and the Politics of Discourse in Cold World America. Cambridge: The MIT Press, 1996.

Gaddis, John Lewis. We Now Know: Rethinking Cold War History. New York: Clarendon Press, 1997.

Gaddis, John Lewis. Strategies of Containment: A Critical Appraisal of Postwar American National Security Policy. New York: Oxford University Press, 1982.

Gallup, George H. The Gallup Poll: Public Opinion, 1935-1971. Vol. 2. New York: Random House, 1972.

Gallup, George H. The Gallup Poll: Public Opinion, 1935-1971. Vol. 3. New York: Random House, 1972.

Ghamari-Tabrizi, Sharon. The Worlds of Herman Kahn: The Intuitive Science of Thermonuclear War. Cambridge: Harvard University Press, 2005.

Gouré, Leon. Civil Defense in the Soviet Union. Berkeley: University of California Press, 1962. 
Grossman, Andrew D. Neither Dead Nor Red: Civil Defense and American Political Development During the Early Cold War. New York: Routledge, 2001.

Gvozdev, M, and V. Iakovkin, Atomnoe oruzhie i protivo atomnaia zashchita (Atomic Weapons and Anti-atomic Defense). Moscow, DOSAAF: 1958.

Handberg, Roger. Ballistic Missile Defense and the Future of American Security: Agendas, Perceptions, Technology, and Policy. Westport, Connecticut: Praeger, 2002.

Hasegawa, Tsuoshi. Racing the Enemy: Stalin, Truman, and the Surrender of Japan. Cambridge: The Belknap Press of Harvard University Press, 2005.

Herken, Gregg. The Winning Weapon: The Atomic Bomb in the Cold War, 1945-1950. New York: Alfred A. Knopf, 1980.

Hershey, John. Hiroshima. New York: Alfred A. Knopf, Inc., 1946.

Hillegas, Mark R. The Future as Nightmare: H.G. Wells and the Anti-utopians. Oxford University Press: New York, 1967.

Holloway, David. Stalin and the Bomb. Yale University Press: New Haven, 1994.

Holsti, Ole R. Public Opinion and American Foreign Policy. Ann Arbor: The University Of Michigan Press, 1996.

Hughs, Thomas P. Rescuing Prometheus. New York: Vintage Books, 1998.

Kahn, Herman. Thinking About the Unthinkable. New York: Horizon Press, 1962.

Kahn, Herman. On Thermonuclear War. Princeton: Princeton University Press, 1960.

Katz, Milton S. Ban the Bomb: The History of SANE, the Committee for a Sane Nuclear Policy, 1957-1985. Greenwood Press, New York, 1986.

Kauffman, James L. Selling Outer Space: Kennedy, the Media, and Funding for Project Apollo, 1961-1963. Tuscaloosa: The University of Alabama Press, 1994.

Khrushchev, Nikita. Khrushchev Remembers, translated and edited by Strobe Talbott. Little, Brown and Company: Boston, 1970.

Khrushchev, Nikita. Khrushchev Remembers: The Last Testament, translated and edited by Strobe Talbott. Little, Brown and Company: Boston, 1974. 
Khurshchev, Sergei N. Nikita Khrushchev: And the Creation of A Superpower. The Pennsylvania University Press: University Park, Pennsylvania: 2000.

Knebel, Fletcher and Charles W. Bailey II. Seven Days in May. New York and Evanston: Harper \& Row, Publishers, 1962.

LaFeber, Walter. America, Russia and the Cold War, 1945-2000, $9^{\text {th }}$ ed. McGraw-Hill: Boston, 2002,

Launius, Roger D. and Howard E. McCurdy, eds. Spaceflight and the Myth Of Presidential Leadership. Chicago: University of Illinois Press, 1997.

Lapp, Ralph. Kill and Overkill: The Strategy of Annihilation. New York: Basic Books, Inc., 1962.

Lapp, Ralph. The Weapons Culture. Baltimore: Penguin Books, Inc., 1968.

Levine, Alan J. The Missile and the Space Race. Westport, Connecticut: Praeger, 1994.

Ley, Willy. Rockets, Missiles, and Men in Space. 5th ed. New York: The Viking Press, 1968.

Lonnquest, John C. and David F. Winkler. To Defend and Deter: The Legacy of the United States Cold War Missile Program, vol. I. Department of Defense Legacy Resource Management Program, Cold War Project. Construction Engineering Research Lab (Army): Champaign, Illinois, 1996.

Lonnquest, John C. and David F. Winkler. To Defend and Deter: The Legacy of the United States Cold War Missile Program, vol. II. Department of Defense Legacy Resource Management Program, Cold War Project. Construction Engineering Research Lab (Army): Champaign, Illinois, 1996.

MacKenzie, Donald. Inventing Accuracy: A Historical Sociology of Nuclear Missile Guidance. Cambridge: MIT Press, 1990.

Martin, Thomas L. and Donald C Latham. Strategy for Survival. Tucson: The University of Arizona Press, 1963.

May, Elaine Tyler. Homeward Bound: American Families in the Cold War Era. Rev. ed. New York: Basic Books, 1999.

McCamley, N.J. Cold War Secret Nuclear Bunkers: The Passive Defense of the western World during the Cold War. Barnsley, South Yorkshire: Pen \& Sword Books, Ltd., 2002. 
McEnaney, Laura. Civil Defense Begins at Home: Militarization Meets Everyday Life in the Fifties. Princeton: Princeton University, 2000.

McDougall, Walter A. ...The Heavens and the Earth: A Political History of the Space Age. New York: Basic Books, Inc., Publishers, 1985.

Morgan, Mark L., and Mark A Berhow. Rings of Supersonic Steel: Air Defense of the United States Army 1950-1979, $2^{\text {nd }}$ ed. San Pedro, California: Fort McArthur Press, 2002.

Neufeld, Jacob. Ballistic Missiles in the United States Air Force, 1945-1960. Washington, D.C: Office of Air Force History, 1990.

Oakes, Guy. The Imaginary War: Civil Defense and American Cold War Culture. New York: Oxford University Press, 1994.

Paletz, David L. and Robert M. Entman. Media, Power, Politics. New York: The Free Press, 1981.

Pollock, Ethan. Stalin and the Soviet Science Wars. Princeton: Princeton University Press, 2006.

Polmar, Norman, ed. Strategic Air Command: People, Aircraft, and Missiles. Annapolis, Maryland: The Nautical and Aviation Publishing Company of America, Inc., 1979.

Rivers, William L. The Opinionmakers. Westport, Connecticut: Greenwood Press, Publishers, 1965.

Rose, Kenneth D. One Nation Underground: The Fallout Shelter in American Culture. New York: New York University Press, 2001.

Roshwald, Mordecai. Level 7. New York: Signet Book, 1959

Schwartz, Stephen I. ed. Atomic Audit: The Costs and Consequences of U.S. Nuclear Weapons since 1940. Washington, D.C.: Bookings Institution Press, 1998.

Shute, Nevil. On the Beach. New York: Ballantine Books, 1957.

Stine, G. Harry. ICBM: The Making of the Weapon that Changed the World. New York: Orion Books, 1991.

Stumpf, David K. Titan II: A History of a Cold War Missile Program. Fayetteville: The University of Arkansas Press, 2000. 
Taubman, Philip. Secret Empire: Eisenhower, the CIA, and the Hidden Story of America's Space Espionage. Simon \& Schuster: New York, 2003.

Taubman, William. Khrushchev: The Man and His Era. W.W. Norton \& Company: New York, 2003.

Titus, A. Constandina. Bombs in the Backyard: Atomic Testing and American Politics." Reno: University of Nevada Press, 1986.

Vanderbilt, Tom. Survival City: Adventures Among the Ruins of Atomic America. New York: Princeton Architectural Press, 2002.

Van Creveld, Martin. Command in War. Cambridge: Harvard University Press, 1985.

Von Bencke, Matthew J. The Politics of Space: A History of U.S.-Soviet/Russian Competition and Cooperation in Space. Boulder: Westview Press, 1997.

Waskow, Arthur I., and Stanley L. Newman. America in Hiding. New York: Ballantine Books, 1962.

Weart, Spencer R. Nuclear Fear: A History of Images. Cambridge: Harvard University Press, 1988.

Wells, H.G. The Last War: A World Set Free. (1914) Lincoln, Nebraska: University of Nebraska Press, 2001.

Wells, H.G. "Time Machine," in The Short Stories of H.G. Wells. London: Earnest Benn Limited, 1957. pp. 9-138.

Wells, H.G. The First Men on the Moon. London: Collins, 1954.

Well, H.G. War of the Worlds. New York: Harper \& Brothers Publishers, 1898.

Wells, H.G. The Island of Doctor Moreau. London: William Heinemann, 1896.

Wicker, Tom. On Press. $3^{\text {rd }}$ ed. New York: The Viking Press, 1978.

Wigner, Eugene P. Survival and the Bomb: Methods of Civil Defense. Bloomington: Indiana University Press, 1969.

Wittner, Lawrence S. Rebels Against War: The American Peace Movement, 1933-1983. Temple University Press, Philadelphia, 1984.

Wood, James Playsted. Magazines in the United States. $3^{\text {rd }}$ ed. New York: The Ronald Press Company, 1971. 
Wylie, Philip. Triumph. Garden City, New York: Doubleday \& Company, Inc., 1963.

Wylie, Philip. Tomorrow! New York: Rinehart \& Company, Inc., 1954.

Yegorov, P.T., Shlyakhov, I.A., and N.I. Alabin. Civil Defense: A Soviet View. Moscow: Translated and Published Under the Auspices of the United States Air Force, 1970.

Zubok, Vladislav, and Constantine Pleshakov. Inside the Kremlin's Cold War: From Stalin to Khrushchev. Cambridge: Harvard University Press, 1996.

\section{MANUSCRIPTS:}

Alonso, Harriet Hyman. "Mayhem and Moderation: Women Peace Activists During the McCarthy Era," in Joanne Meyerowitz, ed., Not June Cleaver. Temple University Press: Philadelphia, 1994.

Brown, JoAnne. "'A is for Atom, B is for Bomb': Civil Defense in American Public Education, 1948-1963." The Journal of American History 75(June 1988): 68-90.

Chernus, Ira. "Operation Candor: Fear, Faith, and Flexibility." Diplomatic History 29 (November 2005): 779-809.

Damms, Richard V. "James Killian, the Technical Capabilities Panel, and the Emergence of President Eisenhower's 'Scientific-Technical Elite."' Diplomatic History 24 (Winter 2000): 57-78.

Garrison, Dee. “ 'Our Skirts Gave Them Courage:' The Civil Defense Protest Movement in New York City, 1955-1961," in Joanne Meyerowitz, ed., Not June Cleaver. Temple University Press: Philadelphia, 1994.

Hartmann, Susan M. "Women's Employment and the Domestic Ideal in the Early Cold War Years," in Joanne Meyerowitz, ed., Not June Cleaver. Temple University Press: Philadelphia, 1994.

Johnson, Andrew M. "Mr. Slessor goes to Washington: The Influence of the British Global Strategy Paper on the Eisenhower New Look." Diplomatic History 22 (Summer 1998): 361-398.

McDougall, Walter A. "Technocracy and Statecraft in the Space Age--Toward the History of a Saltation." The American Historical Review 87 (October 1982): 1010-1040. 
Osgood, Kenneth A. "Form Before Substance: Eisenhower's Commitment to Psychological Warfare and Negotiations with the Enemy." Diplomatic History 24 (Summer 2000): 405-433.

Dockrill, Saki. "Feature Review: Dealing with Soviet Power and Influence: Eisenhower's Management of U.S. National Security," Diplomatic History 24 (Spring 2000): 345-352.

\section{Misc. Publications:}

"Introduction to the Improved Nike Hercules Missile System." http://www.nikemissile.org/.

“The Missile Plains: Frontline of America's Cold War," Minuteman Missile National Historic Site, South Dakota, 2003. http://www.cr.nps.gov/history/online books/mimi/hrs.htm

“Nuclear Weapons Personnel Reliability Program," Number 5210.42, Department of Defense Directive; "DOD Directive." http://www.fas.org/nuke/guide/usa/doctrine/dod/dodd-5210_42.htm

\section{Internet Sites:}

Nike Historical Society

http://www.nikemissile.org/

Global Security.org

http://209.85.165.104/search?q=cache:uf7KVO46U8wJ:www.globalsecurity.org/wmd/fa cility/warren $. h t m+$ atlas + missile + cheyenne, + wyoming $\& h l=e n \& \mathrm{gl}=\mathrm{us} \& \mathrm{ct}=\mathrm{clnk} \& \mathrm{~cd}=4$

Titan I ICBM History Website

http://www.geocities.com/titan_1 missile/

Titan II Missile System

http://www.techbastard.com/missile/titan2/index.php 


\section{VITA}

Jessica Rose Barrella

\section{EDUCATION}

Florida International University

Graduation Date: August 2007

$\mathrm{PhD}$ Candidate in History

Concentration: United States Foreign Relations

Dissertation Title: "Landscape of Fear: A Social History of the Missile during the Early Years of the Cold War, 1950-1965"

Florida International University

Graduation Date: August 2002

Degree: Master of Arts in History

Emphasis on $20^{\text {th }}$ Century American History and the Cold War

Thesis Title: "Fear and U.S. Foreign Policy during the Truman Administration, 1945-1952”

Florida International University

Graduation Date: August 1999

Degree: Bachelor of Arts in History

WORK EXPERIENCE

Florida International University, Miami Fl

January 2007 to Present

Editorial Assistant, Enterprise \& Society

Proofread, format and edit journal articles and book reviews for Enterprise and Society.

Assist with communications between Editor and correspondents.

Florida International University, Miami Fl

August 2002 to April 2005

Teacher's Assistant

Assist Professor in facilitation and teaching of class and evaluation of student assignments.

Help students to study more efficiently and develop and improve their writing techniques.

Research Assistant

May to August 2003

The Kennedy Space Center History Project at NASA in Cape Canaveral, Florida. This work was to assist with writing the history of the space center and included archival research as well as interviewing pertinent subjects.

Research Assistant

January to August 2002

A member of the South Florida Human Dimensions Research Group supported through the Department of the Interior's Critical Ecosystem Studies Initiative to prepare a Public Engagement Primer to suggest ways to engage the public in Florida's Everglades restoration cleanup. 


\section{CONFERENCES AND PRESENTATIONS}

Presented paper entitled "Conformity Through the American Anticommunist Movement, 1950-1955," at the Phi Alpha Theta Annual History Conference at Florida International University, FL April 2004

Presented a paper entitled "The Truman Administration's Utilization of Fear Among the American People, 1948-1953," at "Reconsidering the Cold War," UCSB-GWU Graduate Student Conference, Santa Barbara, CA

May 2003

Presented paper entitled "A Comprehensive Study of How Fear Affected Americans In World War II and the Cold War," at the Phi Alpha Theta Annual History Conference at Florida International University, FL

April 2003

AWARDS

Outstanding Academic Achievement Award

Florida International University's Dissertation Year Fellowship

\section{LANGUAGE SKILLS}

Passed Russian language exam for $\mathrm{PhD}$ requirement

Attended Summer Workshop in Slavic, Eastern European, and Central Asian

Languages (SWSEEL) for intensive Russian Studies at Indiana University, IN

Passed Spanish language exam for M.A. requirement

Summer 2004

\section{PROFESSIONAL AFFILIATIONS}

Society for Historians of American Foreign Relations

Phi Alpha Theta, Florida International University Chapter

American Historical Association

\section{REFERENCES}

Professor Kenneth Lipartito lipark@fiu.edu

305-348-1860

Professor Rebecca Friedman friedmar@liu.edu

$305-919-5839$

Professor Howard Rock rockh@fiu.edu

305-348-2329

Professor Clarence Taylor clarence_taylor@baruch.cuny.org

646-312-4318 